\title{
IntechOpen
}

\section{Nutritional Value of Amaranth}

Edited by Viduranga Y. Waisundara

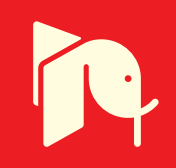





\section{Nutritional Value of Amaranth}

Edited by Viduranga Y. Waisundara 

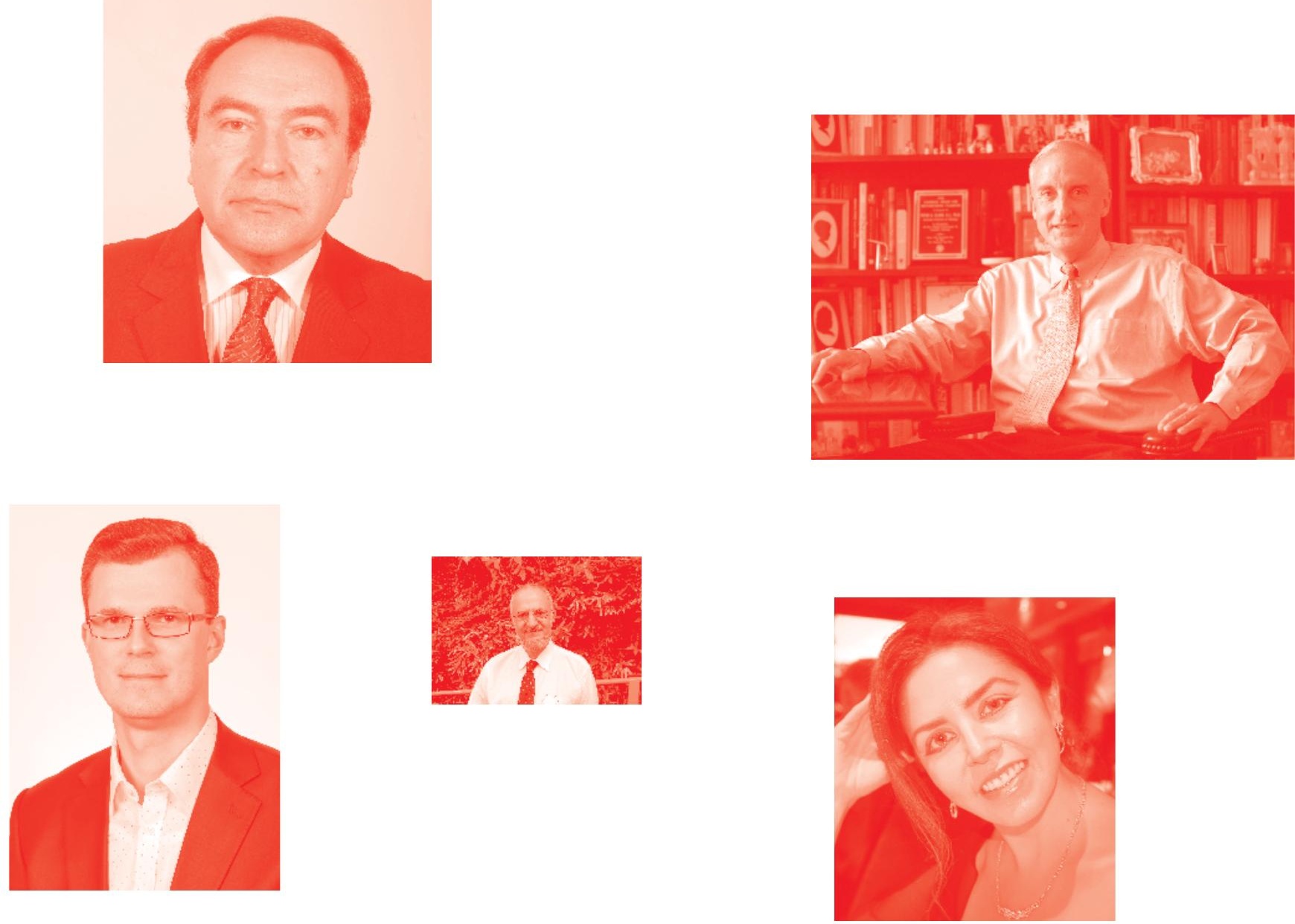

Supporting open minds since 2005
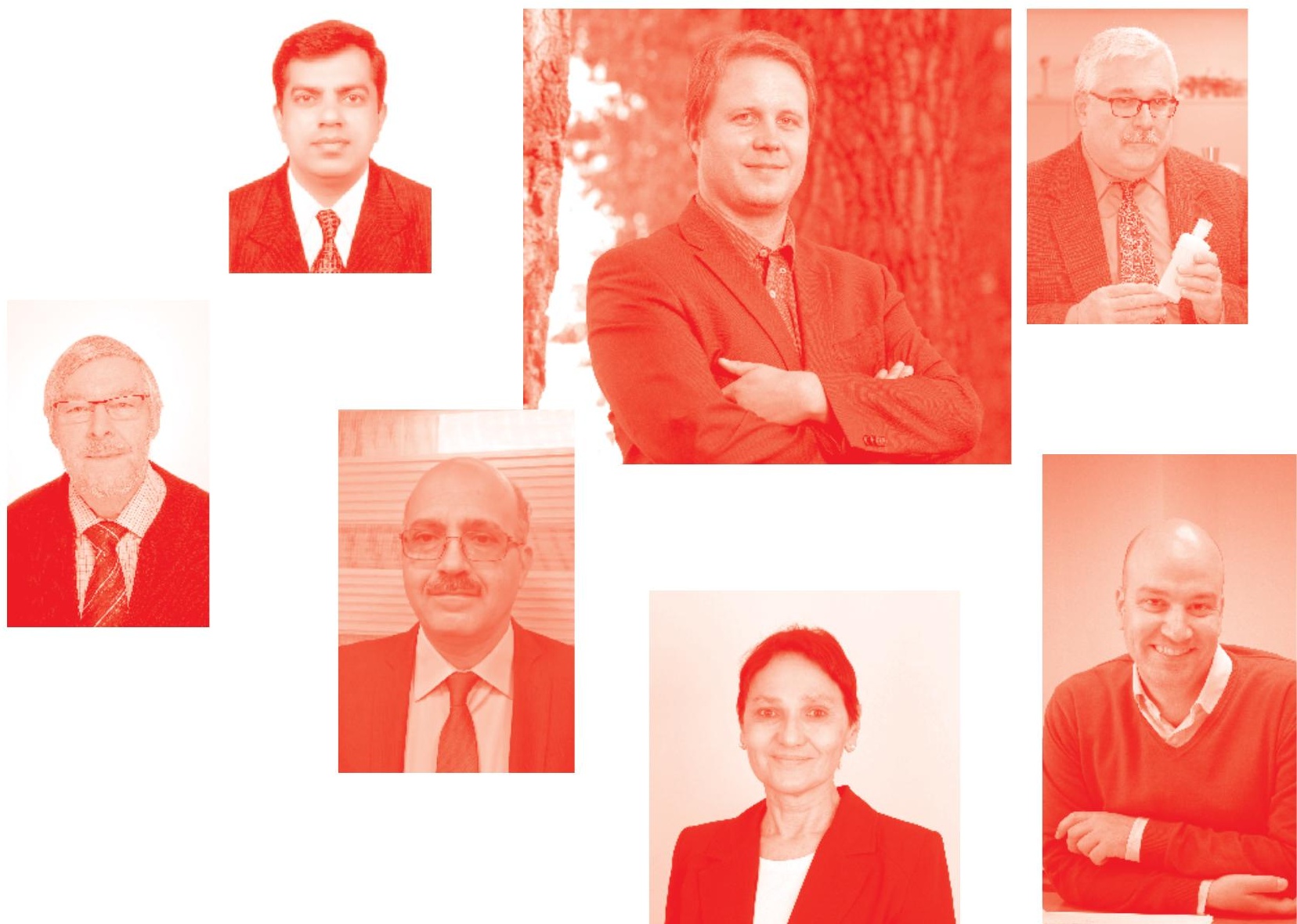
Nutritional Value of Amaranth

http: //dx . doi. org/10.5772/intechopen. 82910

Edited by Viduranga $Y$. Waisundara

\section{Contributors}

Chinedu M. Agu, Albert C. Agulanna, Dinesh Adhikary, Upama Khatri-Chhetri, Jan Slaski, Manuel Soriano-García, Isabel Saraid Aguirre-Díaz, Matthew Chidozie Ogwu, Leticia Xochitl Lopez-Martinez, Ofelia Marquez-Molina, Antonio Torregrosa-García, Javier F. López-Román, Rita Andini, Muhammad Ikhsan Sulaiman, Ángel H. Moreno, Rafael Hernández Maqueda, Carlos J. Torres-Miño, Viduranga Y. Waisundara, Asel C. Weerasekara, Sodeif Azadmard-Damirchi, Javad Hesari, Parisa Nasirpour-Tabrizi, Zahra Piravi-Vanak

( ) The Editor(s) and the Author(s) 2020

The rights of the editor(s) and the author(s) have been asserted in accordance with the Copyright, Designs and Patents Act 1988. All rights to the book as a whole are reserved by INTECHOPEN LIMITED. The book as a whole (compilation) cannot be reproduced, distributed or used for commercial or non-commercial purposes without INTECHOPEN LIMITED's written permission. Enquiries concerning the use of the book should be directed to INTECHOPEN LIMITED rights and permissions department (permissions@intechopen.com).

Violations are liable to prosecution under the governing Copyright Law .

\section{(cc) BY}

Individual chapters of this publication are distributed under the terms of the Creative Commons Attribution 3.๑ Unported License which permits commercial use, distribution and reproduction of the individual chapters, provided the original author(s) and source publication are appropriately acknowledged. If so indicated, certain images may not be included under the Creative Commons license. In such cases users will need to obtain permission from the license holder to reproduce the material. More details and guidelines concerning content reuse and adaptation can be found at http : //www . intechopen . com/copyright-policy . html .

\section{Notice}

Statements and opinions expressed in the chapters are these of the individual contributors and not necessarily those of the editors or publisher. No responsibility is accepted for the accuracy of information contained in the published chapters. The publisher assumes no responsibility for any damage or injury to persons or property arising out of the use of any materials, instructions, methods or ideas contained in the book.

First published in London, United Kingdom, 2020 by IntechOpen IntechOpen is the global imprint of INTECHOPEN LIMITED, registered in England and Wales, registration number: 11086078 , 7th floor, 10 Lower Thames Street, London,

EC3R 6AF, United Kingdom

Printed in Croatia

British Library Cataloguing-in-Publication Data

A catalogue record for this book is available from the British Library

Additional hard and PDF copies can be obtained from orders@intechopen.com

Nutritional Value of Amaranth

Edited by Viduranga $Y$. Waisundara

p. cm.

Print ISBN 978-1-83880-@83-3

Online ISBN 978-1-83880-๑84-

eBook (PDF) ISBN 978-1-83880-185-4 


\section{We are IntechOpen, \\ the world's leading publisher of Open Access books}

Built by scientists, for scientists

\section{$4,700+$}

Open access books available

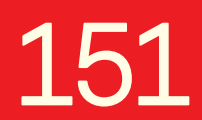

Countries delivered to
$120,000+$

International authors and editors

Our authors are among the

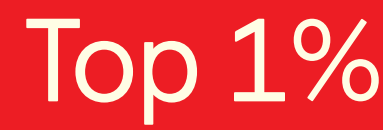

most cited scientists

Contributors from top 500 universities
$135 \mathrm{M}+$

Downloads

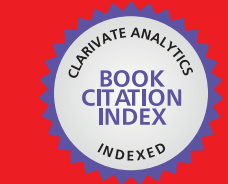

WEB OF SCIENCE ${ }^{\mathrm{MM}}$

Selection of our books indexed in the Book Citation Index in Web of Science ${ }^{\mathrm{TM}}$ Core Collection (BKCI)

\section{Interested in publishing with us? \\ Contact book.department@intechopen.com}

Numbers displayed above are based on latest data collected.

For more information visit www.intechopen.com 



\section{Meet the editor}

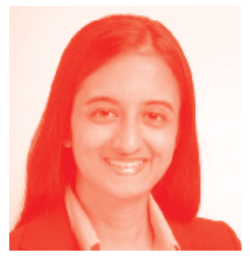

Dr Viduranga Y. Waisundara obtained her Ph.D from the Department of Chemistry, National University of Singapore in Food Science \& Technology in 2010. She was a lecturer at Temasek Polytechnic, Singapore from July 2009 to March 2013. She relocated to her motherland of Sri Lanka and spearheaded the Functional Food Product Development Project at the National Institute of Fundamental Studies from April 2013 to October 2016. She was a Senior Lecturer on a temporary basis, at the Department of Food Technology, Faculty of Technology, Rajarata University of Sri Lanka. She is currently the Deputy Principal of the Australian College of Business \& Technology - Kandy Campus, in Kandy, Sri Lanka. She is also the current Global Harmonization Initiative (GHI) Ambassador to Sri Lanka. 



\section{Contents}

Preface

Section 1

Nutritive Value of Amaranth

Chapter 1

Amaranth as a Pseudocereal in Modern Times: Nutrients, Taxonomy, Morphology and Cultivation

by Asel C. Weerasekara and Viduranga Y. Waisundara

Chapter 2

Adaptation Strategies and Microwave Drying of Amaranth Species with a High Nutritional Value to the Ecuadorian Andean Region

by Carlos J. Torres-Miño, Rafael Hernández Maqueda and Ángel H. Moreno

Chapter 3

Value of Amaranthus [L.] Species in Nigeria

by Matthew Chidozie Ogwu

Chapter 4

Amaranth: An Ancient and High-Quality Wholesome Crop

by Dinesh Adhikary, Upama Khatri-Chhetri and Jan Slaski

\section{Section 2}

Amaranth as a Functional Food

Chapter 5

Potential of Amaranth in Alleviating Malnutrition in Indonesia

by Muhammad Ikhsan Sulaiman and Rita Andini

Chapter 6

Functional Value of Amaranth as Applied to Sports Nutrition

by Torregrosa-García Antonio and López-Román F. Javier

Nutritional Functional Value and Therapeutic Utilization of Amaranth by Manuel Soriano-García and Isabel Saraid Aguirre-Díaz 
Chapter 8

Effect of Various Process Conditions on the Nutritional and

Bioactive Compounds of Amaranth

by Ofelia Marquez-Molina and Leticia Xochitl Lopez-Martinez

Section 3

Amaranth Oil

Chapter 9

Amaranth Seed Oil Composition

by Parisa Nasirpour-Tabrizi, Sodeif Azadmard-Damirchi, Javad Hesari and Zahra Piravi-Vanak

Chapter 10

Kinetics and Thermodynamics of Oil Extracted from Amaranth

by Chinedu M. Agu and Albert C. Agulanna 


\section{Preface}

A pseudocereal can be defined as one of any non-grass species that is used in much the same way as cereals (true cereals are grasses). As per any other cereal, the seed of a pseudocereal can be ground into flour and otherwise used as cereals. Pseudocereals belonging to the genus Amaranthus have been cultivated for their grains for 8,000 years or more. The grain was a staple food of the Aztecs and was also considered an integral part of Aztec religious ceremonies.

This book primarily focuses on three aspects: (1) Nutritive Value of Amaranth (2) Amaranth as a Functional Food, and (3) Amaranth Oil. Much of the Amaranth grain currently grown is sold in health food shops. It has been given due recognition as a nutrient-dense food crop and thus, has been considered as a potential agricultural product to curb food insecurity. The nutritive aspects of Amaranth have been the primary focus of this book project and the chapters included were written by experts working on the promotion of this food crop.

I would like to extend my gratitude to the authors who have supported this book project by submitting chapters. Also, heartfelt appreciation goes to the IntechOpen Publisher with whom I have worked with for many book projects. Last but not least, my appreciation goes to Ms. Sandra Maljavac, the Author Service Manager assigned to this book, who has rendered her utmost support in putting the material together.

I hope that this book will be of value to all those who are interested and involved in research and investigations on pseudocereals such as amaranth. This book will be a significant contribution to expanding the existing knowledge on amaranth and it is hoped that the scientific community will see this crop as a means of curbing many of the nutrient deficiencies around the world.

Dr. Viduranga Y. Waisundara Australian College of Business and Technology, Kandy Campus, Kandy, Sri Lanka 

Section 1

Nutritive Value of Amaranth 



\title{
Amaranth as a Pseudocereal in Modern Times: Nutrients, Taxonomy, Morphology and Cultivation
}

\author{
Asel C. Weerasekara and Viduranga Y. Waisundara
}

\begin{abstract}
Amaranth is a cereal that has been around since ancient times. Its history is deeply embedded in the cultures of the pre-Colombian new world. There are reasons to believe that the Aztecs used it extensively. The grain is able to tolerate harsh weather conditions and also has a high nutrient profile, particularly proteins. Its lysine content in particular is noteworthy. Amaranth has been seen as a means of curbing malnutrition and food insecurity owing to these properties. There are several pseudocereals that have competed with Amaranth for the top spot as a candidate to prevent several nutrient deficiencies. Millet, barley, quinoa and buckwheat are some of those nutrient-dense pseudocereals. However, the nutrient profile of Amaranth is far superior, and the ease of its cultivation has led to it being selected as a grain for cultivation in continents such as Africa where malnutrition and food insecurity are significantly prevalent. Thus, due to the rising nutritional, health and wellness needs of the global population and to provide nutrition for the malnourished, Amaranth appears to be the most viable selection out of all cereals and pseudocereals.
\end{abstract}

Keywords: Amaranth, food insecurity lysine, malnutrition, proteins, pseudocereals, superfoods

\section{Introduction}

Amaranth is considered as one of the "superfoods" of the coming century due to its exceptional qualities in various aspects. However, the crop is not a novel discovery, and it has faced quite a number of obstacles in order to get to where it is today in terms of nutritional status and acceptance by modern day consumers as a food which is able to provide nutrition. Despite the setbacks and disuse, Amaranth has had three redeeming qualities that have earned its standing as a "superfood." The grain is resistant to a number of weather conditions. It also contains quite a high nutrient profile, particularly proteins, and the amino acid lysine, making it a viable supplier of micronutrients to populations facing malnourishment around the globe. The third most important quality is the range of climates and conditions it can grow under. Prior to going into details about Amaranth, it is important to look into the history and nature of similar pseudocereals as a whole in order to understand the importance of Amaranth for modern times. 


\subsection{A brief history of selected pseudocereals and ancient grains}

Amaranth, millet, barley, quinoa and buckwheat are some of the nutrient-dense foods found in the world today. Most of these pseudocereals and ancient grains were regarded as poorer in quality. As a result, these grains were shunned as "poor man's food." However, due to the recent emergence and awareness of their nutritional values, these pseudocereals and ancient grains are making their way back into the diets of people around the world who determinedly want to revert to healthy diets and lifestyles.

Millet's origins could be traced to Neolithic China. Foxtail millet (Setaria italica) and common millet (Panicum miliaceum) are recognized as some of the most important and ancient domesticated crops in the world. The world's earliest known millet remains were found in Cishan around 40 years ago [1]. The storage contained more than $50,000 \mathrm{~kg}$ of grain storage pits, which were not easily taxonomically classifiable at that time. However, since then, it has been suggested that the earliest significant system of common millet cultivation was based around this site in Cishan, and the main crop that was being cultivated therein was common millet [2]. The cultivation and widespread use of millet as a food source has been attributed with the development of early Chinese civilizations that surrounded the Yellow river [2]. The oldest noodles unearthed in the world were also made from foxtail millet and common millet and were found near the Qinghai province in China [3]. The noodles dated back to 4000 years ago [3]. Various other types of millets, such as Kodo millet and pearl millet, were further cultivated in regions throughout the world such as Africa and Asia.

Scientists do not necessarily agree on the origins of barley, and the currently accepted theory states that it has been cultivated first in the Near East [4]. The first ancestor of barley is believed to be similar to Hordeum spontaneum, and the earliest remains of barley discovered so far, date back to 8000 B.C., which were found near the Bus Mordeh phase of Ali Kosh, near Deh Luran and Tell Mureybat in Syria [5]. As agriculture spread from Western Asia toward the valley of Indus, so did barley. Archeologists have found detailed tablets on the correct methods of planting barley, and a prescription for a poultice included barley ale from the scribes of Sumer [6].

Barley has also seen extensive use in ancient Egypt, both as a source of nutrition and a medicine [7]. While being used in many forms to decrease the healing time of wounds, it was also used as medicine for eye diseases and phlegm [7]. Most astonishingly, barley has been used as a marker to diagnose pregnancy and for the purposes of prenatal sex determination-the validity of which has not been proven so far [7]. Much like millet, barley spread across the world and still continues to be a main source of food in many of its parts, including India. Barley tea is prepared using the roasted kernels to make a nonalcoholic drink. This is referred to as a medicinally valuable drink throughout literature [8].

Quinoa is another pseudocereal that has high nutritional properties and values. Before the Chilean and Andean countries began importing wheat, quinoa was one of the staple foods in those regions. The findings in Ayacucho, Peru and Uhle give a basis for the domestication of this plant [9]. Quinoa has thus been in cultivation from pre-Colombian times. During the Colonial period, Inca Garcilaso de la Vega has commented as follows on quinoa: "the second of the grains grown on the face of the earth gives what they call 'quinoa' and it is known in Spanish as 'millet' or small rice: because the grain and color are somewhat similar." This establishes the fact that quinoa has been associated by the Spaniards of the time with Amaranth, which is noted by Bernabe Cobo with how the quinoa within the Iberian Peninsula is very similar to the grain which grew in Europe. Quinoa species were given different names in the context of the variety. The names differed according to color and included names 
such as "isualla, "kana llapi" and "cchusllnca" for wild quinoa, red quinoa and yellow quinoa, respectively [9].

The origins of buckwheat also remain debatable. However, Campbell makes a strong argument for the wild ancestor of buckwheat originating from northeastern Yunnan, China [10]. Nevertheless, evidence of buckwheat has been found in the Siba culture, or the Qinghai-Tibet plateau recently, the carbon dating result of which dated from 3610 to 3458 years before the present, making them the oldest found within the country [11]. This supports the fact that buckwheat has originated within China and in particular, the Qinghai-Tibet plateau. From there, buckwheat spread to Europe through Russia, most likely being introduced to Siberia and Germany first. It is not believed that buckwheat was cultivated within India in ancient times, but there is evidence to support that buckwheat was cultivated within the Himalayas.

\subsection{The importance of Amaranth in modern times}

Out of all the modern day pseudocereals, Amaranth is a strong and upcoming candidate which is foreseen as a remedy to malnutrition and food insecurity. In fact, as mentioned previously, Amaranth is now considered a "superfood" because it is high in protein, dietary fiber, vitamins and minerals. While grains being regularly consumed today possess a high caloric intake, they are micronutrients and protein profiles are not as holistic. A summary of the various nutrient profiles of Amaranthus spp. is shown in Tables 1-3. Popularity in the cultivation and consumption of Amaranth seed in the modern times began almost four decades ago with the rediscovery of its superior nutritional attributes.

\subsection{Taxonomic classification and morphology}

As a plant-based food, it is important to highlight and look into the taxonomic information and morphological characteristics of Amaranth for reference and identification purposes. Taxonomically, plants that belong to the Amaranthus genus have been classified as per Table 4 [13].

The genus Amaranthus has been classified into three subgenera, namely Acnida, Albersia and Amaranthus [14]. However, taxonomic classification within the Amaranthus genus has been regarded as a somewhat difficult task by the scientific community, due to the lack of clearly distinguishing characteristics. Similarities between the large number of species, small, difficult-to-see diagnostic parts, intermediate (hybrid) forms and the broad geographical distribution have been attributed to the general use of multiple synonyms [15]. Due to the need arising for microclassification or infrageneric classification, the Amaranthus genus has been artificially classified into the following, mostly based on the usages [16]:

- Vegetable Amaranthus include Amaranthus tricolor var. tricolor, Amaranthus tricolor var. tristis

- Grain Amaranthus: Amaranthus hypochondriacus, Amaranthus caudatus, Amaranthus cruentus

- Weed Amaranthus: Amaranthus spinosus, Amaranthus viridis, Amaranthus retroflexus

Morphology-wise, the defining characteristics of Amaranth are the inflorescence and the flowers. Hence, taxonomic classification is done mostly by careful 


\begin{tabular}{|c|c|}
\hline Constituent, Amaranthus material & Content \\
\hline \multicolumn{2}{|l|}{ Ascorbic acid } \\
\hline A. caudatus leaf methanol extract & $3.86 \pm 0.20 \mathrm{mg} / 100 \mathrm{~g}$ \\
\hline A. hybridus paste from leaves & $28 \pm 1 \mathrm{mg} / 100 \mathrm{~g}$ \\
\hline $\begin{array}{l}\text { A. lividus stems/leaves/flowers: water/methanol/ethyl } \\
\text { acetate extracts }\end{array}$ & $0.191 \pm 0.007 / 0.196 \pm 0.014 / \mathrm{nd} \mathrm{mg} / \mathrm{g} \mathrm{dw}$ \\
\hline A. hybridus raw/cooked & $321.4 \pm 1.0 / 227.7 \pm 0.7 \mathrm{mg} / 100 \mathrm{~g}$ \\
\hline A. cruentus dried leaves: water extract & $445 \pm 0.21 \mathrm{mg} / \mathrm{kg} \mathrm{dw}$ \\
\hline $\begin{array}{l}\text { A. caudatus seeds: raw/cooked/popped/germinated } \\
\text { and dried } 30^{\circ} / 60^{\circ} / 90^{\circ}\end{array}$ & 29.8/2.3/18.3/13.7/11.4/nd mg/kg \\
\hline $\begin{array}{l}\text { A. cruentus seeds: raw/cooked/popped/germinated and } \\
\text { dried } 30^{\circ} / 60^{\circ} / 90^{\circ}\end{array}$ & 23.0/nd/16.1/14.3/10.7/nd mg/kg \\
\hline $\begin{array}{l}\text { A. cruentus vegetables: market maturity/heading } \\
\text { ( } \beta \text {-carotene, depending on } \mathrm{N} \text { fertilizer) }\end{array}$ & $\begin{array}{l}94.60 \pm 5.60 \text { to } 78.90 \pm 4.50 / 160.50 \pm 7.10 \text { to } \\
149.90 \pm 8.20 \mathrm{mg} / 100 \mathrm{~g} \mathrm{fw}\end{array}$ \\
\hline $\begin{array}{l}\text { A. caudatus seeds: raw/high protein flour/cooked/ } \\
\text { popped/germinated and dried } 30^{\circ} / 60^{\circ} / 90^{\circ}\end{array}$ & 12.5/23.6/1.0/0.7/13.1/9.3/9.1 mg/kg \\
\hline $\begin{array}{l}\text { A. cruentus seeds: raw/high protein flour/cooked/ } \\
\text { popped/ germinated and dried } 30^{\circ} / 60^{\circ} / 90^{\circ}\end{array}$ & 21.3/44.9/1.2/0.7/22.9/20.2/17.9 mg/kg \\
\hline \multicolumn{2}{|l|}{ Niacinamide } \\
\hline $\begin{array}{l}\text { A. caudatus seeds: raw/high protein flour/cooked/ } \\
\text { popped/germinated and dried } 30^{\circ} / 60^{\circ} / 90^{\circ}\end{array}$ & $28.0 / 66.5 / 2.4 / \mathrm{nd} / 30.0 / 23.7 / 23.8 \mathrm{mg} / \mathrm{kg}$ \\
\hline $\begin{array}{l}\text { A. cruentus seeds: raw/high protein flour/cooked/ } \\
\text { popped/germinated and dried } 30^{\circ} / 60^{\circ} / 90^{\circ}\end{array}$ & $15.9 / 32.2 / 0.8 / \mathrm{nd} / 17.1 / 15.5 / 15.2 \mathrm{mg} / \mathrm{kg}$ \\
\hline \multicolumn{2}{|l|}{ Pyridoxine } \\
\hline $\begin{array}{l}\text { A. caudatus seeds: raw/high protein flour/cooked/ } \\
\text { popped/germinated and dried } 30^{\circ} / 60^{\circ} / 90^{\circ}\end{array}$ & $4.5 / 7.6 / 2.2 / 0.5 / 4.3 / 4.4 / 2.5 \mathrm{mg} / \mathrm{kg}$ \\
\hline $\begin{array}{l}\text { A. cruentus seeds: raw/high protein flour/cooked/ } \\
\text { popped/germinated and } 30^{\circ} / 60^{\circ} / 90^{\circ}\end{array}$ & 6.1/8.5/3.1/0.6/5.5/4.5/1.9 mg/kg \\
\hline \multicolumn{2}{|l|}{ Riboflavin } \\
\hline $\begin{array}{l}\text { A. caudatus seeds: raw/high protein flour/cooked/ } \\
\text { popped/germinated and dried } 30^{\circ} / 60^{\circ} / 90^{\circ}\end{array}$ & 2.4/4.9/1.0/1.7/5.3/4.6/1.6 mg/kg \\
\hline $\begin{array}{l}\text { A. cruentus seeds: raw/high protein flour/cooked/ } \\
\text { popped/germinated and dried } 30^{\circ} / 60^{\circ} / 90^{\circ}\end{array}$ & $4.1 / 6.5 / 1.6 / 2.0 / 8.3 / 6.5 / 2.1 \mathrm{mg} / \mathrm{kg}$ \\
\hline \multicolumn{2}{|l|}{ Total folate } \\
\hline 4 varieties: seeds & $52.8-73.0 \mu \mathrm{g} / 100 \mathrm{~g} \mathrm{dw}$ \\
\hline 4 samples: whole meal flour unstored/stored 3 months & $59.9-70.6 / 43.7-61.2 \mu \mathrm{g} / 100 \mathrm{~g} \mathrm{dw}$ \\
\hline 4 samples: flour fraction/bran fraction unstored & $45.5-53.6 / 60.5-81.6 \mu \mathrm{g} / 100 \mathrm{~g} \mathrm{dw}$ \\
\hline 4 samples: noodles/cookies/bread ( $60 \%$ wheat $40 \%$ a.) & $38.9 / 36.3 / 35.5 \mu \mathrm{g} / 100 \mathrm{~g} \mathrm{dw}$ \\
\hline
\end{tabular}

Table 1.

Vitamin components in various Amaranthus spp. (modified from [12]).

examination of the tepal number and morphology. With regards to the general morphology, Amaranth species display erect or spreading annuals with a rough or prickly appearance. Grain amaranths have different colors in regard to flowers, stems and leaves, with shades of purple, orange, red and gold. The seeds are plentiful, while small, and occur in massive numbers, with colors such as cream, gold and pink [17]. The stems are often reddish in color and contain arranged leaves with colorful flowers [18]. The stems are longitudinally grooved and terminate in 
Amaranth as a Pseudocereal in Modern Times: Nutrients, Taxonomy, Morphology and Cultivation DOI: http://dx.doi.org/10.5772/intechopen.90927

\begin{tabular}{|c|c|}
\hline Carotenoids & \\
\hline A. cruentus: treated vegetables (total) & 11.3 to $24.2 \mathrm{mg} / 100 \mathrm{~g}$ \\
\hline A. caudatus: leaf methanol extract (total) & $15.33 \mathrm{mg} / 100 \mathrm{~g}$ \\
\hline A. cruentus: dried leaves water extract (total) & $132 \pm 8 \mathrm{mg} / \mathrm{kg} \mathrm{dw}$ \\
\hline $\begin{array}{l}\text { A. lividus: stems/leaves/flowers: methanol/ethyl acetate } \\
\text { extracts ( } \beta \text {-carotene) }\end{array}$ & $1.24 \pm 0.020 / 0.37 \pm 0.013 \mathrm{mg} / \mathrm{g} \mathrm{dw}$ \\
\hline $\begin{array}{l}\text { A. gangeticus leaves: fresh/pressure cooked } 10 \mathrm{~min} / \text { boiled in } \\
\text { water } 10 \mathrm{~min} \text { ( } \beta \text {-carotene) }\end{array}$ & $7.36 / 5.391 / 2.4 \mathrm{mg} / 100 \mathrm{~g} \mathrm{fw}$ \\
\hline $\begin{array}{l}\text { A. cruentus vegetables: market maturity/heading ( } \beta \text {-carotene, } \\
\text { depending on } \mathrm{N} \text { fertilizer) }\end{array}$ & $\begin{array}{l}7.45 \pm 0.47 \text { to } 8.04 \pm 0.87 / 2.48 \pm 0.33- \\
4.86 \pm 0.57 \mathrm{mg} / 100 \mathrm{~g} \mathrm{fw}\end{array}$ \\
\hline \multicolumn{2}{|l|}{ Chlorophylls } \\
\hline A. cruentus: treated vegetables (chlorophyll a) & $53-132 \mathrm{mg} / 100 \mathrm{~g} \mathrm{fw}$ \\
\hline A. cruentus: treated vegetables (chlorophyll b) & $18.0-43.7 \mathrm{mg} / 100 \mathrm{~g}$ \\
\hline \multicolumn{2}{|l|}{ Betacyanins } \\
\hline $\begin{array}{l}\text { A. spinosus stems: amaranthine/isoamaranthine/betanin/ } \\
\text { isobetanin }\end{array}$ & $15.3 / 5.87 / 1.77 / 0.50 \mathrm{mg} / 100$ \\
\hline
\end{tabular}

Table 2.

Carotenoids, chlorophyll and phytates in various Amaranthus spp. (modified from [12]).

\begin{tabular}{|c|c|}
\hline Phytate & \\
\hline A. caudatus (Centenario and Oscar Blanco) raw grain (phytic acid) & $0.3 \%$ \\
\hline A. caudatus seeds raw/extruded & $82.0 \pm 0.10 / 82.0 \pm 0.13 \mathrm{mg} 100 \mathrm{~g}$ \\
\hline A. cruentus seeds & $5.0-5.8 \mathrm{~g} / \mathrm{kg}$ \\
\hline A. hypochondriacus seeds & $5.4-6.2 \mathrm{~g} / \mathrm{kg}$ \\
\hline $\begin{array}{l}\text { A. cruentus seed: raw flours/high-protein flour fraction/cooked/ } \\
\text { popped/germinated (dried at } 30,60 \text {, and } 90^{\circ} \text { ) }\end{array}$ & $4.0 / 4.4 / 3.3 / 3.4 / 3.1-3.2 \mathrm{~g} / \mathrm{kg}$ \\
\hline $\begin{array}{l}\text { A. caudatus seed: raw flours/ high-protein flour fraction/cooked/ } \\
\text { popped/germinated (dried at 30,60 and } 90^{\circ} \text { ) }\end{array}$ & $4.1 / 4.4 / 3.3 / 3.5 / 3.2-3.3 \mathrm{~g} / \mathrm{kg}$ \\
\hline Amaranthus: eight varieties & $0.52-0.61 \%$ \\
\hline A. cruentus raw seed flours & $21.1 \mu \mathrm{mol} / \mathrm{g}$ \\
\hline \multicolumn{2}{|l|}{ Resinols in Amaranthus seed bran } \\
\hline (+)-Pinoresinol & $53 \mu \mathrm{g} / 100 \mathrm{~g}$ \\
\hline$(-)$-Secoisolariciresinol & $98 \mu \mathrm{g} / 100 \mathrm{~g}$ \\
\hline$(+)$-Lariciresinol & $45 \mu \mathrm{g} / 100 \mathrm{~g}$ \\
\hline (-)-7-Hydroxymatairesinol & $519 \mu \mathrm{g} / 100 \mathrm{~g}$ \\
\hline Syringaresinol & $47 \mu \mathrm{g} / 100 \mathrm{~g}$ \\
\hline Secoisolariciresinol-sesquilignan & $3.7 \mu \mathrm{g} / 100 \mathrm{~g}$ \\
\hline (+)-Medioresinol & $114 \mu \mathrm{g} / 100 \mathrm{~g}$ \\
\hline 7-Oxomatairesinol & $207 \mu \mathrm{g} / 100 \mathrm{~g}$ \\
\hline (-)-Matairesinol & $33 \mu \mathrm{g} / 100 \mathrm{~g}$ \\
\hline Todolactol & $19 \mu \mathrm{g} / 100 \mathrm{~g}$ \\
\hline Isohydroxymatairesinol & $20 \mu \mathrm{g} / 100 \mathrm{~g}$ \\
\hline$\alpha$-Conidendrin & $5.9 \mu \mathrm{g} / 100 \mathrm{~g}$ \\
\hline Nortrachelogenin & $15 \mu \mathrm{g} / 100 \mathrm{~g}$ \\
\hline
\end{tabular}




\begin{tabular}{lc}
\hline Lariciresinol-sesquilignan & $21 \mu \mathrm{g} / 100 \mathrm{~g}$ \\
\hline$(-)$-Arctigenin & $8.2 \mu \mathrm{g} / 100 \mathrm{~g}$ \\
\hline Amines in A. hypochondriacus (Nutrisol) leaves & \\
\hline Cinnamoylphenethylamine & $0.48 ; 0.71 \mu \mathrm{g} / \mathrm{g}$ \\
\hline Caffeoyltyramine & $0.16 ; 0.72 \mu \mathrm{g} / \mathrm{g}$ \\
\hline p-Coumaroyltyramine & $5.26 ; 5.26 \mu \mathrm{g} / \mathrm{g}$ \\
\hline Feruloyl-4-O-methyldopamine & $10.87 ; 7.38 \mu \mathrm{g} / \mathrm{g}$ \\
\hline Amines in in A. mantegazzianus (Don Juan) leaves & \\
\hline Cinnamoylphenethylamine & $4.47 ; 22.31 \mu \mathrm{g} / \mathrm{g}$ \\
\hline Caffeoyltyramine & $0.53 ; 10.27 \mu \mathrm{g} / \mathrm{g}$ \\
\hline Feruloyl dopamine & $0.60 ; 5.67 \mu \mathrm{g} / \mathrm{g}$ \\
\hline Sinapoyltyramine & $0.65 ; 0.35 \mu \mathrm{g} / \mathrm{g}$ \\
\hline$p$-Coumaroyltyramine & $114.31 ; 113.99 \mu \mathrm{g} / \mathrm{g}$ \\
\hline Feruloyl-4-O-methyldopamine & $9.49 ; 31.64 \mu \mathrm{g} / \mathrm{g}$ \\
\hline Enterolactone: Amaranthus extracts & $0.52 \mu \mathrm{g} / 100 \mathrm{~g}$ \\
\hline
\end{tabular}

Table 3.

Other nutrients in various Amaranthus spp. (modified from [12]).

\begin{tabular}{ll}
\hline Kingdom & Plantae-Plants \\
\hline Subkingdom & Tracheobionta \\
\hline Superdivision & Spermatophyta \\
\hline Division & Magnoliophyta \\
\hline Class & Magnoliopsida \\
\hline Subclass & Caryophyllidae \\
\hline Order & Caryophyllales \\
\hline Family & Amaranthaceae \\
\hline Genus & Amaranthus L. \\
\hline
\end{tabular}

Table 4.

Taxonomic classification of Amaranthus spp.

an apical large branched inflorescence [19]. Grain amaranth plants are dicots with thick, tough stems similar to those of sunflowers. The height can vary between 1.524 and $2.134 \mathrm{~m}$ when mature.

Leaves vary in shapes and sizes and are usually either green or purple with slender stalks. These are alternate, usually simple, with entire margins and distinct markings but without stipules, depending on the species. Flowers are either solitary or aggregated in cymes, spikes, or panicles and typically bisexual and actinomorphic. A few species have unisexual flowers. The bracteate flowers are regular with 4-5 petals, often joined. There are 1-5 stamens. The hypogynous ovary has 3-5 joined sepals [20]. The flowers have 0-5 perianth segments and 2-3 styles [20].

Seeds are borne in a utricle, which are classified as dehiscent, semi-dehiscent, or indehiscent types. The amaranth seed is quite small $(0.9-1.7 \mathrm{~mm}$ diameter $)$ and seed 
weights vary from 1000 to 3000 seeds/g. Seed colors can vary from cream to gold and pink to black. The tiny, lens shaped seeds are usually pale in color. The seed heads vary from 30 to $112 \mathrm{~cm}$ in diameter at the base and varied in height from 13 to $61 \mathrm{~cm} \mathrm{[20].}$

The vegetable Amaranthus can be identified by inflorescence features such as mostly or exclusively axillary glomerulus, or short spikes, origin of the flower bud from leaf axil, three tepal lobes, three stamens, brownish black seed, indeterminate growth habit [20]. Grain Amaranthus are characterized by the apical large complex inflorescence comprising aggregates of cymes, five tepal lobes, stamens, seed with variable coat color and well-defined flange, utricle circumscissile [21]. Certain species within weeds show commonalities with the grain and vegetable forms, and some weed species are cultivated as food sources [22].

There is a recurring conflict based around the origins of the grain Amaranth, and the scientific community has introduced a variety of hypotheses around this debate. There are various hypotheses, none of which have been quite adequately tested as of yet. The single progenitor hypothesis [22] claims that the grain amaranths could be the result of a single progenitor species domestication that has been introgressed with other wild amaranths resulting in separate grain species. Another hypothesis claims that multiple different grain species were resultant of separate domestication incidents around separate regions, pertaining to different wild species. A. cruentus is from A. hybridus presumably in Central America, A. hypochondriacus is from $A$. powellii in Mexico and $A$. caudatus is from $A$. quitensis in South America [22]. A third hypothesis proposes that each of the three domesticated species were derived from independent domestication events from genetically different populations of $A$. hybridus [23].

\subsection{Amaranth cultivation around the world: a brief history}

The initial evidence of Amaranth cultivation dates back to the mid-Holocene period (8000-7000 BP) [24]. In Central America, seeds of A. hypochondriacus and A. cruentus were found which date back 1500 and 6000 years, respectively, from Mexico [25]. The three main grain Amaranth species cultivated throughout different regions in America are A. cruentus, which is cultivated throughout North America, particularly in and around Southern Mexico and Guatemala, A. hypochondriacus, which is cultivated through the western part of America, particularly from southwestern America to central Mexico, as well as A. caudatus, which is cultivated closer to Southern America, particularly near the Andes and Northern Argentina [17].

Amaranth has its history deeply imbedded in the cultures of the pre-Colombian new world. There are reasons to believe that the Aztecs used it extensively. There have been references to tributes of tons of Amaranth grain being sent to Tenochtitlan (present-day Mexico City) for emperor Montezuma [17]. The Aztecs would mix the crushed grain with human blood or milk and consume it during their rituals and festivals [17]. As such, the grain was interwoven with paganism and the rituals of the Aztecs. The Spanish conquistadors were shocked by this and banned the use and cultivation of Amaranth, pushing cultivation into small pockets, and eventually into disuse [17]. Nevertheless, as time went on, the conquistadors would distribute the seed as far as India, Nepal and China. The crop is popular among the hill tribes of these countries, and Amaranth is most intensively cultivated in these areas of higher elevation as of today [17]. Additionally, amaranth has been indoctrinated into Indian culture, earning names such as "rajgira" and "ramdana" (king seed and seed sent from god, respectively) [17]. Indian cuisine such as "laddoo" incorporates a mixture of popped amaranth seeds and honey [17]. 
Amaranth species such as $A$. tricolor, $A$. dubius and $A$. cruentus are grown as potherbs or vegetables within the African and Southeast Asian regions [26]. Research regarding utilizing Amaranth species as an alternative food crop to support the global demands is already underway, and new advances toward Amaranth cultivation are being carried out in countries such as Lithuania [27]. Furthermore, research has been conducted into cultivating $A$. hypochondriacus hybrids within the Iranian region as a new food crop, which have been successful [28]. The heat resistance of Amaranth spp. has made it an acceptable food crop for Taiwan which has high rainfall and humidity conditions coupled with temperatures that can reach up to $40^{\circ} \mathrm{C}$ [29]. Amaranth is grown as a leafy vegetable in Nigeria [30]. Additionally, recent research in Italy has confirmed that the country possesses conditions that $A$. hypochondriacus derivatives find suitable for cultivation [31]. While specialized research is being carried out around cultivation patterns to obtain optimal results in the Russian republic Dagestan [32]. Others have followed suit, specializing their research in order to obtain optimal conditions for the crop based on the conditions within the land, including such institutes as the Rodale Research Center (RRC), the central source for Amaranth and related research of America, in Pennsylvania, Emmaus. Recent publications include studies into variations in protein content, studies into Genomic reductions, germination characteristics and germplasm conservation.

\subsection{Amaranth in the future}

Due to the demanding needs of the twenty-first century's population and their need for nourishment, the efficiency of crops such as corn, rice and maize are being questioned. As such, scientists worldwide are making new ventures into the potential of alternative grains that could supply food to the world in the years to come. Quinoa, buckwheat and other forgotten pseudocereals are being presented into the limelight due to their high nutrient content and their ease of growth. Amaranth is at the forefront when it comes to all these aspects.

The first world Amaranth conference was held in 2018, gaining 135 participants from East and Southern African countries where the grain is most needed. Topics discussed were mainly centered on nutrition, production of quality food on African land, processing, and supporting communities to change mentalities developed around Amaranth as a poor man's crop. The underutilization of the crop seems to be the main issue, especially in countries which need its nutritional benefits the most. However, steps are being taken to change the public's view and are effective as evident by the attendance of the African continent.

\section{Conclusions}

Due to the rising needs of the global population to control world hunger and to provide nutrition for the malnourished, Amaranth becomes a viable selection due to a number of reasons. Its weed-like nature and ability to withstand environmental conditions is one of these reasons. Another is its ability to provide micronutrients and macronutrients at significant amounts as a single crop, as opposed to the current food crops of the world. Amaranth contains lysine at high levels in particular, compared with other cereals and pseudocereals. The third most striking characteristic is its adaptability to change and the wide range of environments it can grow under, making it a competitive crop that can be utilized across the globe in order to cater to both the poor and the rich. This fact alone solidifies its position as a versatile food crop which could eventually become a staple food of the twenty-first century. 
Amaranth as a Pseudocereal in Modern Times: Nutrients, Taxonomy, Morphology and Cultivation DOI: http://dx.doi.org/10.5772/intechopen.90927

\section{Acknowledgements}

The authors wish to thank the Australian College of Business \& Technology Kandy Campus, Peradeniya Road, Kandy, Sri Lanka, for the facilities provided to put this write-up together.

\section{Conflict of interest}

The authors declare no conflicts of interest, financial or otherwise.

\section{Author details}

Asel C. Weerasekara and Viduranga Y. Waisundara*

Australian College of Business and Technology, Kandy Campus, Kandy, Sri Lanka

*Address all correspondence to: viduranga@gmail.com

\section{IntechOpen}

(C) 2020 The Author(s). Licensee IntechOpen. This chapter is distributed under the terms of the Creative Commons Attribution License (http://creativecommons.org/licenses/ by/3.0), which permits unrestricted use, distribution, and reproduction in any medium, provided the original work is properly cited. (cc) BY 


\section{References}

[1] Handan Relics Preservation Station, Education Team of Cishan Archaeology. Preliminary excavation of Neolithic sites in Cishan, Hebei Province. Kaogu (Archaeology). 1977;6:361-372

[2] Lu H, Zhang J, Liu KB, Wu N, Li Y, Zhou K, et al. Earliest domestication of common millet (Panicum miliaceum) in East Asia extended to 10,000 years ago. Proceedings of the National Academy of Sciences. 2009;106(18):7367-7372

[3] Lü H, Li Y, Zhang J, Yang X, Ye M, Li $\mathrm{Q}$, et al. Component and simulation of the 4,000-year-old noodles excavated from the archaeological site of Lajia in Qinghai, China. Chinese Science Bulletin. 2014;59(35):5136-5152

[4] Harlan JR. On the origin of barley. In: Barley: Origin, Botany, Culture, Winter Hardiness, Genetics, Utilization, Pests. USDA Agric. Handb. No. 338. 1979. pp. 10-36

[5] Newman CW, Newman RK. A brief history of barley foods. Cereal Foods World. 2006;51(1):4-7

[6] Kramer SN. History Begins at Sumer: Thirty-Nine Firsts in Recorded History. 3rd edition. University of Pennsylvania Press; 1 April 1988

[7] Kramer SN. The Sumerians: Their History, Culture, and Character. Revised edition. University of Chicago Press; 15 February 1971

[8] Wallace LH. Barley water. In: The Rumford Complete Cookbook. Rumford, RI: The Rumford Co.; 1930. p. 222

[9] Kramer SN. Sumerian Mythology.

Revised edition University of Pennsylvania Press; 29 October 1998

[10] Campbell CG. Buckwheat: Fagopyrum esculentum Moench.
Promoting the Conservation and Use of Underutilized and Neglected Crops. Leibniz Institute of Plant Genetics and Crop Plant Research. 1997;19:93. ISBN: 978-92-9043-345-3

[11] Wei YM. Buckwheat remains from the late Neolithic site of Donghuishan, Gansu Province, China. Cereal Chemistry. 2019;96(2):332-337

[12] Venskutonis PR, Kraujalis P. Nutritional components of amaranth seeds and vegetables: A review on composition, properties, and uses. Comprehensive Reviews in Food Science and Food Safety. 2013;12(4):381-412

[13] United states Department of Agriculture. Amaranthus L. n.d. Available from: https://plants.sc.egov. usda.gov/core/profile?symbol=AMARA

[14] Mosyakin SL, Robertson KR. New infrageneric taxa and combinations in Amaranthus (Amaranthaceae). In: Annales Botanici Fennici. Helsinki, Finland: Finnish Zoological and Botanical Publishing Board; 1996. pp. 275-281

[15] Jacobsen SE, Mujica A. The genetic resources of Andean grain amaranths (Amaranthus caudatus L., A. cruentus L. and A. hipochondriacus L.) in America. Plant Genetic Resources Newsletter. 2003;133:41-44

[16] Das S. Systematics and taxonomic delimitation of vegetable, grain and weed amaranths: A morphological and biochemical approach. Genetic Resources and Crop Evolution. 2012;59(2):289-303

[17] National Research Council. Amaranth: Modern Prospects for an Ancient Crop. Washington, DC, USA: The National Academies Press; 1984. https://doi.org/10.17226/19381 
[18] Rathod KJ. Phytochemical Studies of Rajigara amaranthus Species for Its Potential Use in Medicine. Saurashtra University. Department of Botany; 2017

[19] Sauer JD. The grain amaranths and their relatives: A revised taxonomic and geographic survey. Annals of the Missouri Botanical Garden. 1967;54(2):103-137

[20] New world encyclopaedia.

Amaranth. [Online]. Available from: https://www.newworldencyclopedia. org/entry/Amaranth. [Accessed: 18 July 2019]

[21] Stallknecht GF, Schulz-Schaeffer JR. Amaranth Rediscovered New Crops. New York: Wiley; 1993

[22] Kielinski KD, Jimenez F, Jellen EN, Maughan PJ, Smith SM, Pratt DB. Relationships between the Weedy (Amaranthaceae) and the Grain Amaranths. Crop Science. 2014;54(1):220-228

[23] Maughan PJ, Smith SM, Fairbanks DJ, Jellen EN. Development, characterization, and linkage mapping of single nucleotide polymorphisms in the grain amaranths (Amaranthus sp.). The Plant Genome. 2011;4(1):92-101

[24] Arreguez GA, Martínez JG, Ponessa G. Amaranthus hybridus L. ssp. hybridus in an archaeological site from the initial mid-Holocene in the southern Argentinian Puna. Quaternary International. 2013;307:81-85

[25] Joshi DC, Sood S, Hosahatti R, Kant L, Pattanayak A, Kumar A, et al. From zero to hero: The past, present and future of grain amaranth breeding. Theoretical and Applied Genetics. 2018;131(9):1807-1823

[26] Svirskis A. Investigation of amaranth cultivation and utilization in Lithuania. Agronomy Research. 2003;1(2):253-264

[27] Alemayehu FR, Bendevis MA, Jacobsen SE. The potential for utilizing the seed crop amaranth (Amaranthus spp.) in East Africa as an alternative crop to support food security and climate change mitigation. Journal of Agronomy and Crop Science. 2015;201(5):321-329

[28] Yarnia M, Benam MK, Tabrizi EF. Sowing dates and density evaluation of amaranth (cv. Koniz) as a new crop. Journal of Food, Agriculture \& Environment. 2010;8(2):445-448

[29] Holmer R, Linwattana G, Nath P, Keatinge JD, editors. SEAVEG 2012: High Value Vegetables in Southeast Asia: Production, Supply and Demand. Taiwan: AVRDC-World Vegetable Center; 2013

[30] Oke OL. Amaranth in Nigeria. In: Proceedings of the Second Amaranth Conference. Emmaus, Pennsylvania, USA: Rodale Press; 1980. pp. 22-30

[31] Casini P, La Rocca F. Amaranthus cruentus $\mathrm{L}$. is suitable for cultivation in Central Italy: Field evaluation and response to plant densities. Italian Journal of Agronomy. 2014:166-175

[32] Anatolyevich SD, Viktorovna SS, Magomedovich MH. Development of elements of technology of cultivation of amaranth in cover crops on irrigated lands sredneshirotnykh plains of dagestan. International Agricultural Journal. 2018;61(2). DOI: 10.24411/2588-0209-2018-10012 



\title{
Adaptation Strategies and Microwave Drying of Amaranth Species with a High Nutritional Value to the Ecuadorian Andean Region
}

\author{
Carlos J. Torres-Miño, Rafael Hernández Maqueda \\ and Ángel H. Moreno
}

\begin{abstract}
In the Andean region of Ecuador, amaranth is a key species not only for its high nutritional value but also for its association with Ecuadorian culture, since it is one of the main indigenous crops of the pre-Columbian era. Over the time, the cultivation of this species ceased for several reasons result. However, in recent years, a number of strategies have been developed to retrieve it on a national level. In accordance with these strategies, the "Amaranth Improvement Program for Cotopaxi" (PROMAC) is being developed at the Technical University of Cotopaxi, with the main objective of selecting varieties with high levels of biologically active substances. This program is been executed through two main lines of investigation: (a) selection of varieties of amaranth of high nutritional value and (b) the improvement of techniques for conservation of the seeds. This chapter analyzes and shows the main results obtained to date from the study of eight varieties of amaranth seeds and the drying of one of the seeds by means of microwave energy in order to improve its conservation. In the light of the results obtained, the strategies to develop the following research lines within the PROMAC framework are exposed.
\end{abstract}

Keywords: amaranth, Amaranthus spp., adaptive response, microwave drying, conservation strategies, post-harvest techniques

\section{Introduction}

Amaranth is a crop of America, whose origin and exploitation probably dates back to between 4000 and $5000 \mathrm{BC}$. According to [1, 2], the first evidence of domestication is located in Central America (Guatemala and Mexico) and South America (Ecuador, Peru and Bolivia). Known as huauhtli, it refers to the amaranth species A. hipochondriacus L., a pseudocereal which for those tribes had a sociocultural and economic significance. Its value was as great as that of corn and beans, the traditional crops of these people. 
It should be noted however that according to several chronicles, the term huauhtli was used not only to refer to amaranth (Amaranthus) but also to quenopodios (Chenopodium).

The American origin of several Amaranthus species, employed nowadays for the production of grain, has been confirmed by several archeological studies. Amaranth was used even before the beginning of domestication [3]. In particular, the excavations carried out by MacNeish (1964) yielded some very interesting data about the crop. Amaranth seeds were found in their excavations, as a result of which they concluded that this crop was grown during the Coxacatlán period (5000-3400 years BC), which means that the domestication of amaranth occurred at the same time as that of corn.

On the basis of these data, it is clear that the amaranth was a crop widely used by the Aztecs and their neighbors [3]. Under the empire of Moctezuma II, amaranth seeds were highly valued, first as one of the main crops in people's diet, and second because amaranth seeds were used to make figures of Aztec idols [4]. They were also used in religious ceremonies among the ancient Mexicans, in honor of the Aztec god of the sun and war "Huitzilopochtli" and the god of rain "Tlaloc" [5]. It is widely believed that, because of its use in religious ceremonies, this crop was considered as a symbol of paganism after the Spanish conquest, and its cultivation was consequently prohibited. However, no conclusive evidence has been found of the gradual disappearance and prohibition of amaranth cultivation as a result of Spanish conquest [4].

The first species cultivated in the pre-Columbian era to obtain grain were: A. hypochondriacus L. in Mexico, A. caudatus L. in the Andean region, and A. cruentus L. over a wide area of Central America [3, 5]. The introduction of the first amaranth plants to Europe occurred during the colonial era, when they were used as ornamental plants. The seeds employed for the production of amaranth were the black variety. However, samples of the white A. hypochondriacus L. seed that date from the sixteenth century were also found [3]. This indicates that Amaranthus seeds came to Europe in the form of two varieties (black and white), though black seeds were the most commonly used.

The dispersion of amaranth seeds to other continents may have occurred through commercial traffic from Europe to other regions of the world, such as Asia. In this region, particularly in Sri Lanka (known initially as Ceylon) and in India, there are traces of crops whose records date back to the eighteenth century. It is believed that the seeds were introduced by the Dutch. In the first half of the nineteenth century, the crop expanded across the Deccan plain in South India and the Himalayas. It is also known that in the nineteenth century, its cultivation began in China and eastern Siberia [3].

Currently, amaranth is considered one of the most promising crops for combating malnutrition in this century [6,7] for several reasons: first, because of its adaptability to unfavorable environmental conditions [8], second because its cultivation does not demand much water and its agronomic management does not require much care, making its production cheaper compared with other similar crops [9], and finally, because of its high nutraceutical value $[6,10]$.

Amaranth is a rich source of protein $[6,7,10,11]$, vitamins, fiber, and calcium $[1-3,6,7,10]$. Consequently, it is used as a food (mainly the leaves and the seeds), but also as an additional protein supplement for livestock. Moreover, it is used in medicine because of anti-inflammatory, hemostatic, and diuretic properties $[6,7]$. And more recently, the flour of amaranth has attracted the attention of industry because of its chemical composition and nutritional value $[7,12]$. For these reasons, the interest of researchers and cultivators in amaranth seeds has increased considerably in recent years [7]. 
In Ecuador, this crop is known as Ataco, Sangorache or Quinua de Castilla and is used mainly as fodder. Several species can be found: A. blitum L. and A. hybridus L., also known as bledos. In the Costa region, $A$. dubius Mart. ex Thell. has also been found [13]. However, the species that are most commonly used as crops are: A. quitensis Kunth or A. hybridus L.

As a means to recover this crop, the National Program of Legumes and Andean Grains was created in 1982. An important part of the plan was to collect amaranth seeds over an extensive area of approximately $1000 \mathrm{~km}$ in the inter-Andean alley. A total of 114 samples were registered up to the year 1985, most of which belonged to the A. hybridus species. [14].

Subsequently, a knowledge exchange program between different institutions involved in the development of the amaranth crop was introduced. As a result of this, the species Amaranthus cruentus L.- - the INIAP Alegría variety, obtained from the"Alan García" variety, was introduced from the University of San Antonio Abad in Cusco, Peru.

Before being introduced, this variety had passed a previous selection process in the National Institute of Agricultural Research (INIAP), in the years 1987 and 1988.

The INIAP Alegría variety was released to farmers in 1994 [1] after several years of research into its management, adaptability, and grain processing among other aspects.

Currently, in Ecuador, the cultivation of the ancient crops quinoa (Chenopodium quinoa Will.), Lupinus (Lupinus mutabilis L.), and amaranth (Amaranthus spp.) is experiencing a rate of very high growth. Of these crops, the one in greatest demand for export is quinoa. However, amaranth is also in high demand in the United States, where NASA is carrying out research into the potential of amaranth as a source of nutrition for astronauts [15].

Despite the growing interest in this crop and its enormous potential, more research is required regarding crop management, adaptation strategies, and postharvest techniques in order for this crop to be considered as a main source of food in Ecuador.

\section{Program for improvement and selection of amaranth in Cotopaxi (PROMAC)}

For the reasons explained above, various programs have been introduced in Ecuador to adapt and improve amaranth crops. One of these programs is the Program for Improvement and Selection of Amaranth in Cotopaxi (PROMAC) the main objective of which is to develop and implement strategies for adapting amaranth species to the conditions of the province.

The program arises from the need to incorporate new promising lines of research that will amaranth crops to be reintroduced into the province of Cotopaxi. The work has been developed mainly at the Technical University of Cotopaxi in Latacunga and has been carried out in collaboration with the Russian Federal Center for Scientific Research in Vegetables (VNIISSOK) and the Russian University of Friendship of Peoples (RUDN).

This program has followed two strategic lines of research:

The first line has the aim of selecting varieties of amaranth of high nutritional value to be adapted to the Andean region, while the second line aims to improve the techniques used to conserve the seeds, since in the case of Cotopaxi, seed conservation is one of the least efficient processes and is the cause of the high loss of seeds that seriously affects the crop yield. This program began in early 2016 and is still ongoing. 
A summary of the progress made to date of the two lines of investigation mentioned above is presented below.

\section{Selection of varieties with a high nutritional value}

This work is partly based on the research previously carried out in The Federal Center for Scientific Research on Vegetables (VNIISSOK) of Russia which has one of the highest number of amaranth seed collections of the Russian Federation.

As part of the project carried out in this institution, 10 varieties were released for production in the central zone of Moscow and some areas of Southern Russia [16].

The objective planned within the framework of the PROMAC was to ascertain whether the varieties previously studied in Russia could be adapted to the conditions of Cotopaxi. This study was incorporated as part of two degree courses $[17,18]$.

\subsection{Material employed and variables analyzed}

The study of the adaptability of amaranth in Cotopaxi began with the characterization of different samples from the All Russian Research Institute N.I. Vavilov.

Table 1 shows the samples selected, with references to their origin and the corresponding species.

As can be seen in Table 1, there are some collections of samples that were not identified in their storage origin due basically because they share intermediate morphological characters with close relatives. The identification of the remaining species is considered in a second phase of the program (PROMAC) based on morphological, biochemical, and genetic markers.

Each of the collections was planted, in different experimental units. For this purpose, $8.3 \mathrm{~m}^{2}$ plots were designed.

Then, different biometric and physiological indicators were measured according to the recommendations of Mujica [19] and Torres [20].

The color of the seeds, stem length, inflorescence length, and the number of leaves at the time of harvesting were employed as biometric indicators. Data were obtained from 10 plants in each plot. Likewise, after harvesting, the average weight of 1000 seeds was calculated.

\begin{tabular}{lcc}
\hline Origin & Collection number & Species \\
\hline Belgium & VIR NN & A. caudatus \\
\hline Belgium & VIR 666 & A. cruentus \\
\hline France & VIR 686 & A. cruentus \\
\hline United States & VIR 796 & Amaranthus $\mathrm{sp}$. \\
\hline Mongolia & VIR 690 & A. hybridus \\
\hline Argentina & VIR 674 & A. hypochondriacus \\
\hline Mexico & VIR 584 & Amaranthus sp. \\
\hline China & VIR 711 & Amaranthus $\mathrm{sp}$. \\
\hline
\end{tabular}

VIR identify code number for the All Russian Research Institute N.I. Vavilov.

NN, No number assigned.

Table 1.

Species employed in the study. 
Adaptation Strategies and Microwave Drying of Amaranth Species with a High Nutritional... DOI: http://dx.doi.org/10.5772/intechopen.88843

\begin{tabular}{lcc}
\hline Time to emergence & Scale & Classification \\
\hline Less than 10 days & 1 & Short-term \\
\hline From 11 to 15 days & 2 & Medium-term \\
\hline More than 16 days & 3 & Long-term \\
\hline
\end{tabular}

Table 2.

Seed emergence time scales according to [20].

The physiological indicators used were: the number of days for seeds to emerge, the number of days for a milky grain and for a dry grain, and the number of days for physiological maturation.

The number of days for the seeds to emerge was measured in the seedbed. The time at which $70-80 \%$ of seeds germinated was recorded and classified according to the scale shown in Table 2.

In order to corroborate the relation between the variables analyzed, a Pearson's correlation coefficient analysis was performed, in combination with a conglomerate analysis to group the species studied.

\subsection{Biometric and physiological differences between the species studied}

The adaptability tests for the eight varieties studied were successful, although some differences between the different species were found depending on the variables analyzed.

Based on the data recorded, the following results were obtained:

The color of the seeds recorded at the time of harvest revealed four specimens of white seed (of different shades), three collections of black seed, and one collection of brown seeds, as shown in Figure 1.

The results of the analysis of the morphological variables: stem length, inflorescence length, and the number of leaves are shown in Figure 2.

The stem lengths, ranged between $23 \mathrm{~cm}$ for Amaranthus sp. (originating in China) and $130 \mathrm{~cm}$ for Amaranthus cruentus, originally from Belgium.

The size of the panicle (inflorescence length) oscillated between $17 \mathrm{~cm}$ on average for the species Amaranthus cruentus, originally from Belgium and the

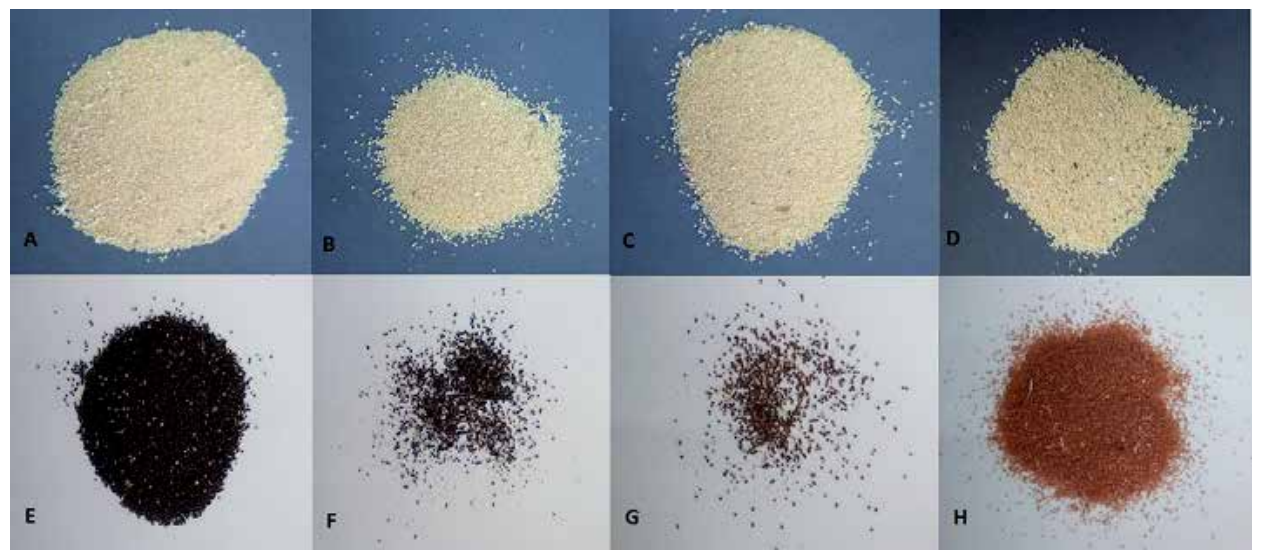

Figure 1.

Color of the amaranth seeds employed in the study. A, A. cruentus (France); B, A. hypochondriacus (Argentina); C, Amaranthus sp. (Mexico), D, A. hybridus (Mongolia); E, A. cruentus (Belgium); F, Amaranthus sp. (China); G, Amaranthus sp. (USA); H, A. caudatus (Belgium). 


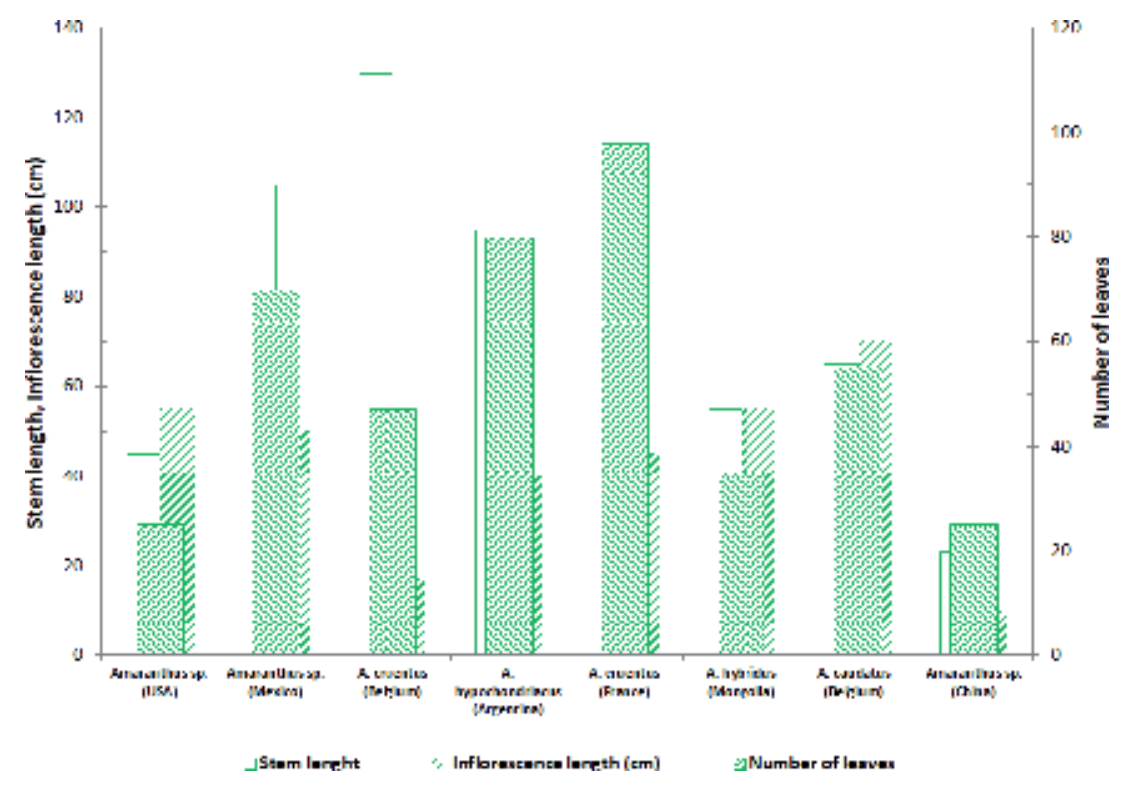

Figure 2.

Behavior of the biometric variables analyzed.

species Amaranthus sp. originating in China, and $70 \mathrm{~cm}$ on average for the species Amaranthus caudatus, from Belgium.

The Pearson correlation coefficient test applied to check the possible relationship between these two variables yielded a value of -0.74 , which indicates that there is an inversely relationship between the size of the stem and the size of the panicle.

As regards the number of leaves at the time of amaranth harvest, as in the case of the previous indicators, interspecific differences are observed. The species that accumulated most leaves at the time of harvest were: $A$. cruentus (France), A. hypochondriacus (Argentina), and Amaranthus sp. (Mexico), with an average of between 70 and 98 leaves. The second range included $A$. caudatus (Belgium), A. cruentus (Belgium), and $A$. hybridus (Mongolia) with values between 35 and 55 on average. The last range included Amaranthus species from China and the USA, with an average of 25 leaves.

Analysis of the correlation between the stem size and number of leaves yielded a coefficient of 0.66 , which indicates a moderate correlation between these two variables.

Finally, no significant differences were found between the weights of the seeds, with values ranging between 0.75 and $0.81 \mathrm{~g}$. Only the amaranth species native of China showed a very low value $(0.54 \mathrm{~g})$ on average.

No correlation was observed between the weight of the seeds and the remaining variables.

The behavior of the different physiological variables analyzed is shown in Figure 3.

If we analyze the days for the seeds to emerge (Figure 3) in relation to Table 2, it can be observed that the only short-term germination species is $A$. hybridus (Mongolia). It took only 8 days to germinate. The long-term germination species were $A$. caudatus (Belgium) and Amaranthus sp. from China. The rest of the species belong to the medium-term range.

The species that attained physiological maturity first was the species Amaranthus sp. (USA) within 157 days on average, followed by the species $A$. hypochondriacus (Argentina) within 158 days on average. The species that took longest to reach physiological maturity was $A$. cruentus (France) within 193 days on average. 


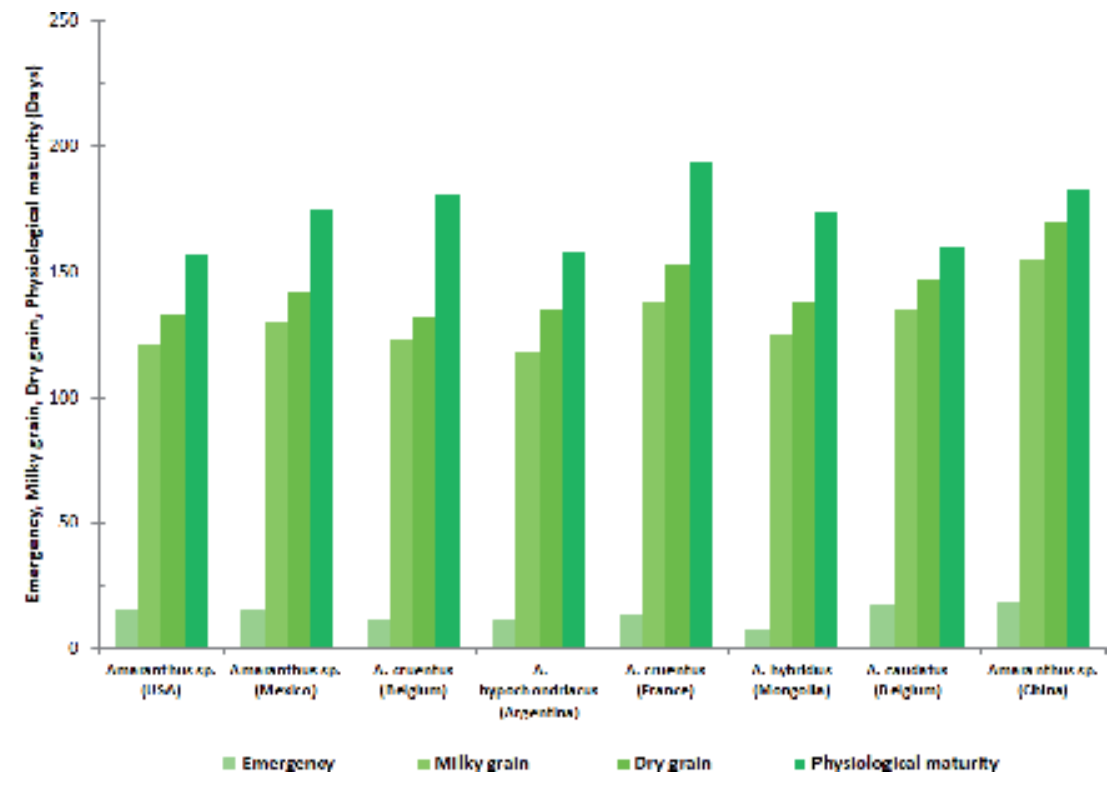

Figure 3.

Behavior of the physiological variables analyzed in the study.

As can be seen in Figure 3, there is a relationship between the days taken to acquire a milky grain appearance, a dry grain appearance, and physiological maturity, because these three variables refer to the same physiological process involved in the evolution of the seed in the plant.

However, analysis of the Pearson correlation coefficient test of the days required for seed emergence versus the days needed to reach physiological maturity yielded a coefficient of -0.062 which indicates that there is no correlation between the two variables. This indicates that the processes that regulate the emergence of the seed follow a different path to the processes that lead to reach the physiological maturity of the plant.

According to the physiological criteria, the species with a higher adaptive potential are the species from USA and A. hypochondriacus, due to its shorter time to reach the maturity.

Figure 4 shows a general analysis of all the variables considered to establish a cluster analysis.

In summary, if all the variables are considered together, it can be concluded that all the species presented an adequate ability response to the climatic conditions of the essay performed, because all of them reached the expected biometric and physiological values referred in the literature [8]. On the other hand, based on the time to reach the maturity, the promissory species are those from USA and Argentina (Amaranthus sp. and A. hypochondriacus, respectively).

The species that presented the lowest values for the different indicators analyzed was the species from China. As can be seen in Figure 4, it is also the most distant species in the cluster analysis. Unfortunately, the species has not been identified correctly, so it is difficult to establish whether this adaptability difficulty is due to genetic characteristics or climatic factors.

On the other hand, it is observed how the species $A$. cruentus presents phenotypic variability. Figure 4 shows how the species from Belgium is grouped with $A$. hypochondriacus, while the species of $A$. cruentus from France is closer to $A$. caudatus.

This study is merely the starting point for adapting the amaranth species to the scenario of Cotopaxi. However, the results obtained are promising and will contribute to obtaining varieties that in the near future can be released to farmers. 


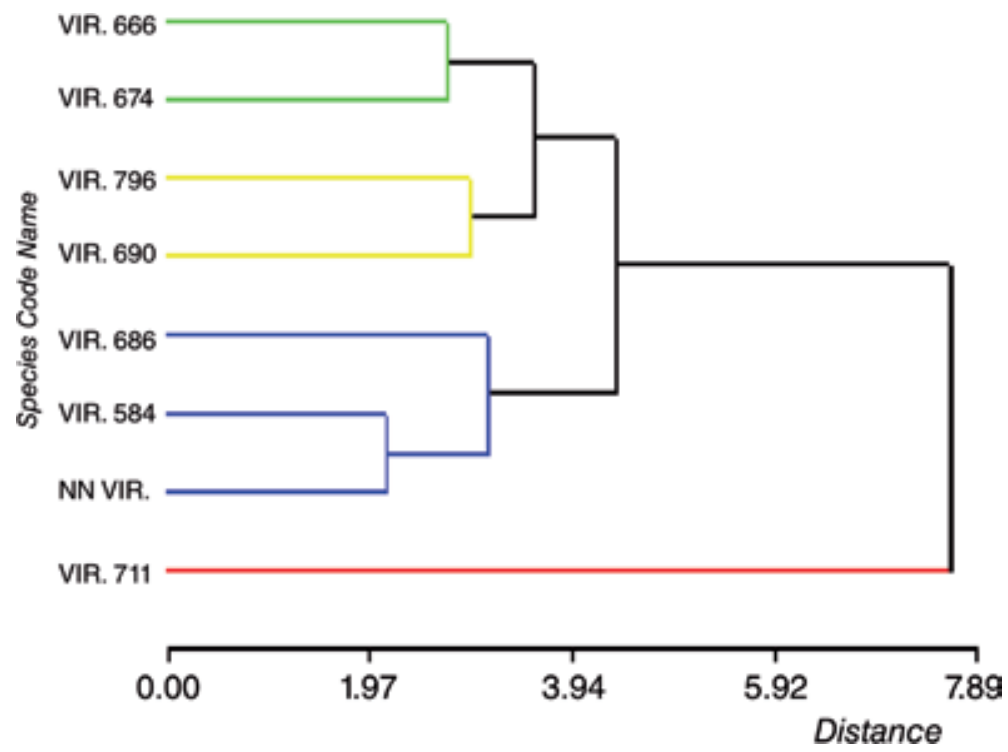

Figure 4.

Dendogram of the species under study. VIR $711=$ Amaranthus sp. $($ China $), V I R N N=A$. caudatus (Belgium), VIR $690=$ A. hybridus (Mongolia), VIR $686=$ A. cruentus (France), VIR 674 = A. hypochondriacus (Argentina), VIR $666=$ A. cruentus (Belgium), VIR $584=$ Amaranthus sp. (Mexico), VIR $796=$ Amaranthus sp. (USA). The values shown in the X-axis indicates distance among species based on the different variables analyzed.

\section{Improvement of the drying process of amaranth seeds by using microwave energy}

The second strategic line of investigation designed within the framework of the PROMAC was to improve the conservation of amaranth seed after it has been harvested.

Amaranth is usually harvested when its moisture content ranges from 22 to $30 \%$ $[8,21]$. However, to ensure that this pseudocereal is well conserved for long periods of time, it is necessary to reduce these high moisture contents to levels ranging between 10 and $12 \%$ [8].

Amaranth seeds, like other seeds, can be dried naturally or artificially. In the Andean region of Ecuador, the drying of these seeds is carried out, fundamentally, in a traditional way, by exposing them to the air and taking advantage of solar energy. This method of drying has several disadvantages such as that there is little control over the process, as long periods of time (more than 15 days), and large open spaces are required for its completion and in many cases non-uniform drying occurs. Moreover, the seeds are exposed to climatic variations that reduce their viability and quality, making them susceptible to damage caused by environmental pollution, pests, and diseases [22-24].

To avoid the disadvantages of sun drying, several artificial drying methods have been developed [25-27]. However, none of these are suitable for satisfying all the needs and drying requirements of the different types of seed. The grain drying system may be classified into solar drying, batch drying, and continuous flow drying systems [26]. The dryers most commonly used to dry seeds are fixed bed dryers (batch) and sliding bed dryers, in their various configurations (concurrent, counter-current, and cross flows) $[25,26]$. In relation with these systems, the drying process of several seeds, grains, and agricultural products, such as corn, wheat, rice, etc., has been widely investigated, and the results of the studies have 
been reviewed by several authors [25, 27-36]. However, in scientific literature, there are very few publications on the drying of amaranth seeds $[21,37,38]$, reflecting the relatively scare attention paid to this particular seed. Moreover, in these studies, although the drying tests of amaranth seeds were carried out at different temperatures, the influence of this important operation parameter on the viability and quality of the seeds was not evaluated. Moreover, the small size of amaranth seeds (geometric mean diameter of $\sim 1.15 \mathrm{~mm}$ ) impedes their use in conventional systems and makes it difficult to achieve good results in the drying process [39].

Although such techniques have proved to be highly effective for drying, they are handicapped by the high energy consumption involved [40, 41]. This drawback has motivated the search for and development of other more efficient drying systems from the energy point of view which do not affect the viability and quality of the seeds. One such technique is microwave-assisted drying, that has been developed as an alternative technique to conventional methods of drying seeds and agricultural products, due to the numerous advantages it offers [22, 24, 42, 43]. Of these advantages, the following are noteworthy. High drying rates and, consequently, shorter drying times; a greater energy efficiency; the generation and more efficient use of heat, due to the deeper penetration of microwave energy in the products to be dried and to the reduction of heat loss since it is not necessary to heat the entire volume of the drying chamber to dry the product; precise and instantaneous electronic control that allows an adequate control of the drying temperature and a prompt commencement completion of the process; greater uniformity during the drying process; lower drying temperatures that will reduce the thermal gradients and drying imperfections of conventional methods and ensure the quality of the product to be dried, while preventing the migration of other materials to the surface, and offering a cleaner drying process, which does not generate secondary waste. For these reasons, it is not surprising that the number of studies aimed at evaluating the potential of the microwave oven for seed drying has increased enormously in recent years [22, 24, 42-47].

In this section, the main results obtained in the Research Project "Evaluation of the drying process in microwave oven of seeds of agricultural interest for the province of Cotopaxi", carried out in the Technical University of Cotopaxi, in Ecuador, are reported and analyzed with regard to the drying of amaranth seeds $(A$. caudatus).

The drying of the amaranth seeds, as part of this project, was carried out by means of two different experimental processes.

i. Microwave energy drying (a) in a microwave oven without any temperature control (at different power densities) and (b) in a microwave oven with temperature control (at different temperatures).

ii. Drying by the forced convection of hot air in electric ovens, at different temperatures (for comparative purposes).

\subsection{Variables employed for the evaluation of the drying and germination of amaranth seeds}

To evaluate the drying and germination of the amaranth seeds, three main variables were used: the drying time, energy consumption, and germination rate of the seeds.

Drying time is the time required to reduce the moisture content of the seed mass from its initial value to the desired final value under controlled drying conditions (temperature, pressure, seed mass, etc.). It is one of the main variables that 
characterize the drying process and is widely used for comparative purposes between one set of operating conditions and another as well as between different types of dryers. Moreover, this variable has a significant impact on others of vital importance, such as the energy consumption and the operating cost of the drying process.

Energy consumption is another very important variable in the drying process, as it is in other industrial processes. Drying is considered to be one of the unit operations with the highest energy consumption [48-50], because to eliminate water it is necessary to supply the latent heat of vaporization $\left(2400 \mathrm{~kJ} \mathrm{~kg}^{-1}\right)$. The minimum energy needed to perform this task is referred to as evaporation load [48]. However, commercially available conventional dryers, to compensate for the different heat losses that occur in them and/or in the heat supply system, consume an amount of energy that is significantly greater than the latent heat of vaporization [48]. In addition, energy consumption is directly related to the emission of greenhouse gases (GHGs) and other polluting gases and the operating cost of the process, so it is essential to reduce this consumption in order to reduce the carbon footprint and improve the economy of the drying process.

Finally, the rate or percentage of germination, according to the International Seed Testing Association [51] indicates the percentage of germinated seeds which have produced seedlings classified as normal in the conditions and the period specified. Germination is the emergence and development of the seed embryo of essential structures (shoots and roots) which, for a particular seed, are indicative of its ability to produce a normal plant under favorable conditions [52]. To determine the viability of a seed, tests are carried out on the basis of its germination capacity after the drying process or after any other type of treatment. The aim of the germination test is to determine the germination capacity of a seed lot, in order to be able to compare the quality of different batches of seeds that have been subjected to different treatments and also to be able to estimate their field planting value [51]. Moreover, the germination rate is useful for calculating the seed requirements for a given area or a desired number of plants, it follows, therefore, that the ability of seeds to germinate (viability) is one of the fundamental parameters to be evaluated in seed conservation.

\subsection{The drying of amaranth seeds with microwave energy}

\subsubsection{In a microwave oven without any temperature control (at different power densities)}

First, the amaranth seeds were dried in a rotating-turntable domestic microwave oven (General Electric Co., JES710WK), with a total output power of $700 \mathrm{~W}$ (Figure 5). In this oven, the drying of the seeds was evaluated at three microwave power densities: $0.875,1.75$, and $3.5 \mathrm{~W} / \mathrm{g}$.

The experimental procedure consisted in placing the mass of seeds required to obtain the desired power density in a paper box, which was in turn placed on the turntable of the microwave oven. The mass of seeds was weighed every $2 \mathrm{~min}$, and the seeds were dried until a moisture content of $8 \%$ was obtained. Full details of the experimental set-up can be found elsewhere [53]. Table 3 shows the results obtained in the drying process of the amaranth seeds in this oven at the power densities studied.

As can be seen in Table 3 as the power density increased, from 0.875 to $3.5 \mathrm{~W} / \mathrm{g}$, the drying time required to reach a moisture content of $8 \%$, their germination rate and energy consumption decreased simultaneously. The reduction in drying time $(\sim 72 \%)$ and energy consumption $(\sim 72 \%)$ are essential developments for reducing the operating costs of the drying process. However, the differences 


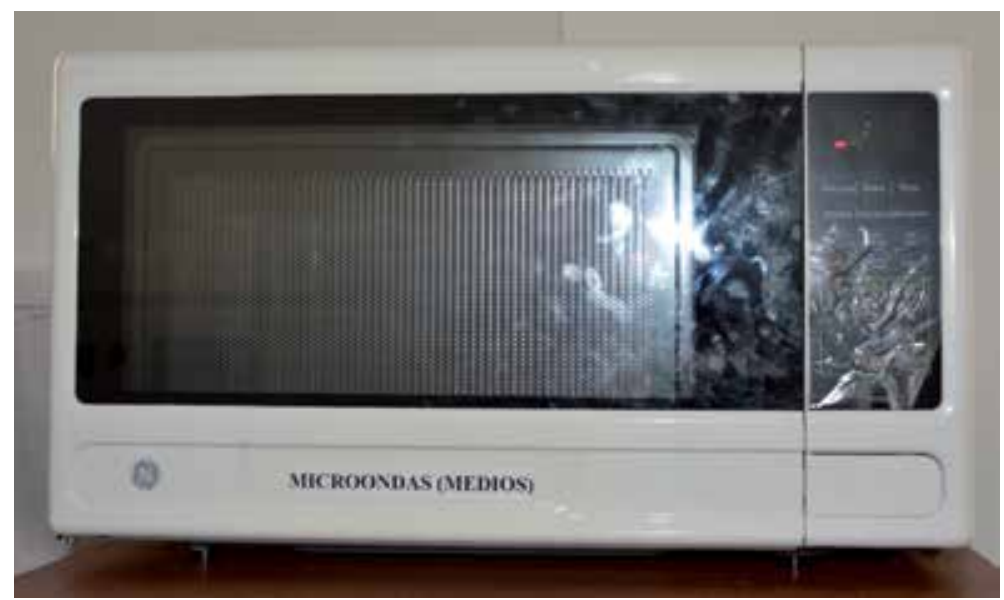

Figure 5.

Microwave oven (General Electric Co., JES710WK).

\begin{tabular}{lccc}
\hline Variables evaluated & \multicolumn{3}{c}{ Power densities (W/g) } \\
\cline { 2 - 4 } & $\mathbf{0 . 8 7 5}$ & $\mathbf{1 . 7 5}$ & $\mathbf{3 . 5}$ \\
\hline Drying time (min) & 31.3 & 15.3 & 8.7. \\
\hline Estimated energy consumption $(\mathrm{Wh})$ & 364.8 & 178.5 & 101.5 \\
\hline Germination rate $(\%)$ & 78 & 72 & 71 \\
\hline
\end{tabular}

Table 3.

Results of the drying of amaranth seeds in a microwave oven (General Electric Co., JES710WK) at different power densities.

observed in the germination rate of the seeds are not statistically significant, and in all three cases, the germination rates are acceptable (>70\%) [53]. This decrease in viability as a function of power density has also been observed in soybean [54], in corn seeds [55], and in wheat [56]. The decrease in the germination rate of the seeds with the increase in the power density may have been due to the fact that the drying temperature was also increased thereby affecting the ability of the seeds to germinate.

In summary, with the increase of power density in the microwave drying process, there is a simultaneous decrease in drying time, in energy consumption, and in the germination rate of the amaranth seeds. To avoid a decrease in the germination rate of the seeds, it is necessary to use low power densities.

\subsubsection{In a microwave oven with temperature control (at different temperatures)}

Subsequently, the amaranth seeds were dried, with microwave energy at a controlled temperature in a rotating turntable domestic multimode microwave oven (LACOR Model 69330) equipped with a $900 \mathrm{~W}$ magnetron, at a frequency of $2.45 \mathrm{GHz}$ and a voltage of $220 \mathrm{~V}$ (see Figure 6). The microwave device is also equipped with a type K thermocouple connected to a PID Eurotherm $3216 \mathrm{~L}$ controller which controls the amount of power delivered and allows the temperature to be monitored and controlled continuously.

In this oven, $100 \mathrm{~g}$ of amaranth seeds, with an initial humidity of between 16 and $20 \%$ (wb), was placed in a microwave plastic container (105 mm long, $105 \mathrm{~mm}$ wide, and $45 \mathrm{~mm}$ high). The uncovered container was placed on the microwave 


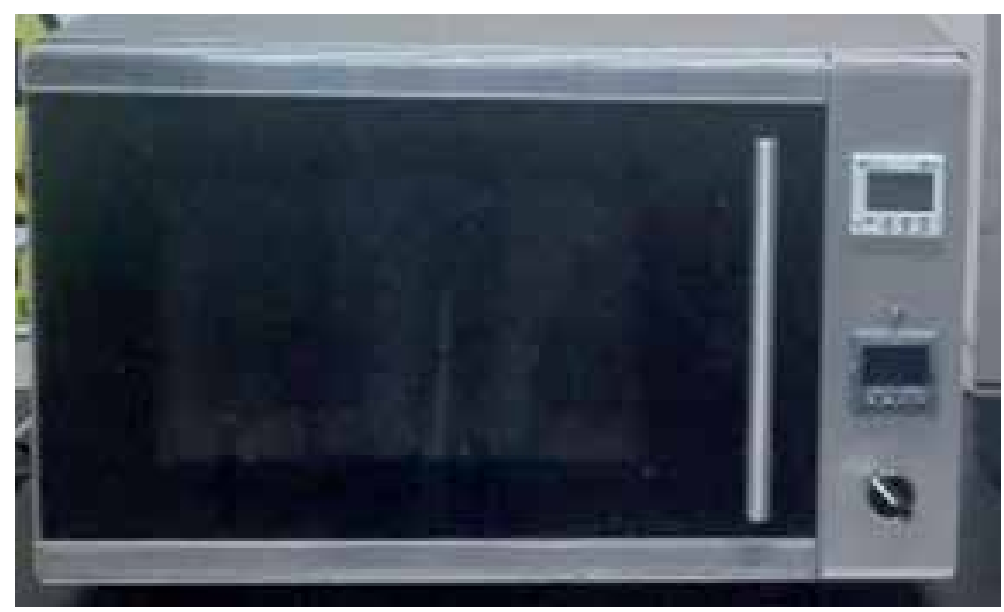

Figure 6.

Microwave oven (LACOR Model 69330).

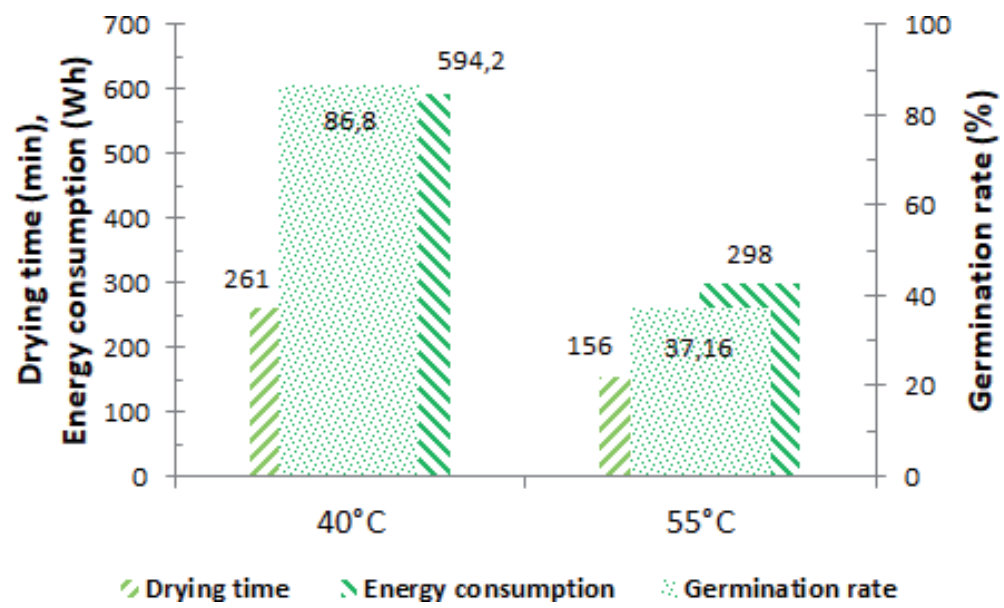

Figure 7.

Results of the microwave drying of amaranth seeds at the two temperatures studied and of their germination tests.

oven dish ( $315 \mathrm{~mm}$ in diameter), and the thermocouple was immersed in the bed of seeds. The amaranth seeds were heated up to the same drying temperatures used when drying by forced convection by hot air in the electric ovens analyzed in Section 4.3 ( 40 and $55^{\circ} \mathrm{C}$, respectively). All the experiments were carried out with the turntable in stationary mode to avoid fluctuations in the measurements of seed temperature. The seeds were weighed every $30 \mathrm{~min}$, and the drying process was considered to be completed when a humidity of $12 \%$ was obtained. For each drying temperature studied, the experiment was replicated five times. In each experiment, the electrical energy consumption was measured using a FLUKE 435 Series II energy analyzer. The effect of the drying temperature on the three variables evaluated is shown in Figure 7.

As can be seen in Figure 7 at the lowest drying temperature $\left(40^{\circ} \mathrm{C}\right)$, the highest values of the three variables studied were obtained: drying time (261 $\mathrm{min})$, energy consumption $(594 \mathrm{Wh})$, and germination rate of the seeds $(86.7 \%)$. It can also be observed that at the highest drying temperature $\left(55^{\circ} \mathrm{C}\right)$, there were significant decreases in the values of these variables: the drying time decreased by 
approximately $40 \%$, energy consumption by $50 \%$, and the rate of germination of the seeds by $57 \%$. The decrease in these three variables with temperature was also observed in the microwave drying of corn seeds [57]. As we previously pointed out, the reduction in drying time $(\sim 40 \%)$ and energy consumption $(\sim 50 \%)$ are positive developments for reducing the operating costs of the drying process. However, the decrease in the germination rate of seeds to values as low as $37 \%$ is unacceptable. These results show that the drying temperature is a variable of vital importance in the drying process of amaranth seeds, due to the sensitivity of the germination capacity of these seeds to temperature.

In sum, with the increase in the microwave drying temperature, there is a simultaneous decrease in drying time, energy consumption, and germination rate of amaranth seeds. In order to obtain high germination rates in the drying process of amaranth seeds, it is necessary to dry the seeds at a temperature of $40^{\circ} \mathrm{C}$.

\subsection{Drying of amaranth seeds by forced convection of hot air in electric ovens}

Finally, for comparative purposes, the amaranth seeds were dried by forced convection of hot air in two electric ovens, one conventional (Figure 8a, INCUCELL, LSIS-B2V/IC 55) and the other (Figure 8b, UTC-IEM-2017), designed and built in the Faculty of Engineering and Applied Sciences, of the Technical University of Cotopaxi, as part of the Research Project. These electric ovens have a total output power of 700 and $450 \mathrm{~W}$ respectively. The experimental procedure consisted in placing the mass of seeds in a container, which was in turn placed on the grill of the oven. The amaranth seeds were heat up to a drying temperature of $40^{\circ} \mathrm{C}$ (in the UTC-IEM-2017 oven) and $55^{\circ} \mathrm{C}$ (in the INCUCELL oven). The mass of seeds was weighed every $30 \mathrm{~min}$, and the seeds were dried until a moisture content of $8 \%$ (in the INCUCELL oven) and of 12\% (in the UTC-IEM-2017 oven) were obtained.

Table 4 shows the average values obtained for the three variables evaluated in the drying process performed in each electric oven.

In Table 4, it can be seen that the drying time and the germination rate of the seeds were lower ( 36 and $23 \%$, respectively) in the INCUCELL oven than in the UTC-IEM-2017 oven; while the consumption of electric power was $20 \%$ higher. This behavior is mainly due to the higher drying temperature and the lower final moisture of the seeds used in this oven, since the higher the drying temperature, the faster the rate of the process and, consequently, the lower the drying time. Moreover, the lower the final moisture content of the seeds, the greater the energy consumption required to evaporate the humidity. The lower germination rate of the seeds recorded at a drying temperature of $55^{\circ} \mathrm{C}$ in the INCUCELL oven agrees with the results obtained in the microwave drying process at this temperature. This result

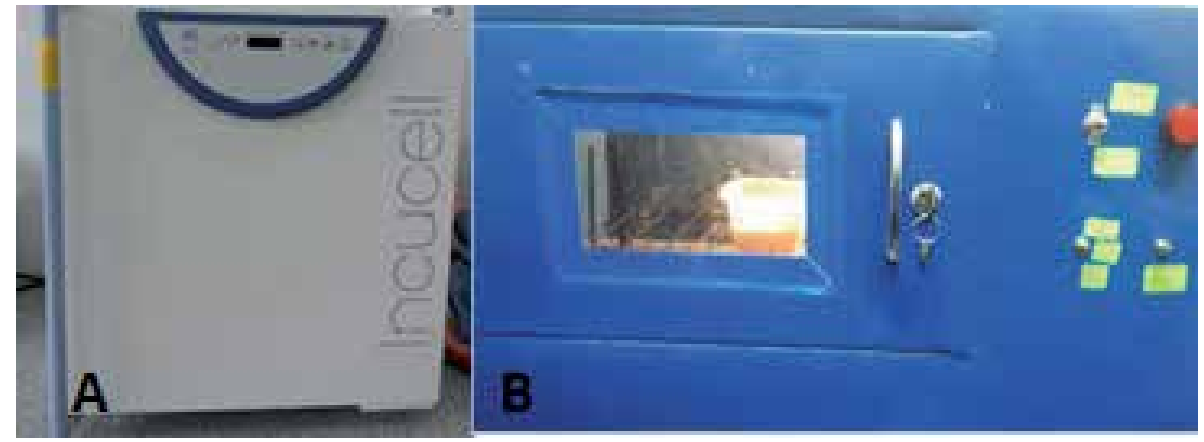

Figure 8.

(a) Electric oven (INCUCELL, LSIS-B2V/IC 55) and (b) electric oven (UTC-IEM-2017). 


\begin{tabular}{|c|c|c|}
\hline \multirow[t]{4}{*}{ Variables evaluated } & \multicolumn{2}{|c|}{ Electric ovens } \\
\hline & INCUCELL, LSIS-B2V/IC 55 & UTC-IEM-2017 \\
\hline & \multicolumn{2}{|c|}{ Drying temperature $\left({ }^{\circ} \mathrm{C}\right)$} \\
\hline & 55 & 40 \\
\hline Drying time (min) & 248 & 336 \\
\hline Energy consumption (kWh) & $2.89^{*}$ & $2.31^{* *}$ \\
\hline Germination rate (\%) & 74 & 90.8 \\
\hline $\begin{array}{l}\text { Estimated. } \\
\text { Measured. }\end{array}$ & & \\
\hline
\end{tabular}

Table 4.

Results of the drying of amaranth seeds by the forced convection of hot air.

confirms the decrease in the germination capacity of amaranth seeds at temperatures above $40^{\circ} \mathrm{C}$.

In summary, the drying process of amaranth seeds by forced convection with hot air in the two ovens studied is characterized by high drying times and high energy consumption. In these ovens, the drying temperature should not exceed $40^{\circ} \mathrm{C}$ to avoid a decrease in the germination rate of the seeds to unacceptable values.

\subsection{Comparative analysis between drying process of amaranth seeds by forced convection of hot air and microwave drying}

In the previous sections, the results obtained in the drying process of amaranth seeds, using two different drying methods, were analyzed: drying with microwave energy at different power densities (Section 4.2.1) and at controlled temperatures (Section 4.2.2), and drying by hot air convection (Section 4.3.). In this section, a comparative analysis of the results obtained in the drying of this seed is carried out, using the same experimental parameters: drying temperature $\left(40^{\circ} \mathrm{C}\right)$, initial seed mass $(100 \mathrm{~g})$, final moisture of the seeds (12\%), but in two different drying installations: drying with microwave energy at controlled temperatures (Microwave oven LACOR Model 69330) and drying by hot air convection (electric oven UTC-IEM-2017).

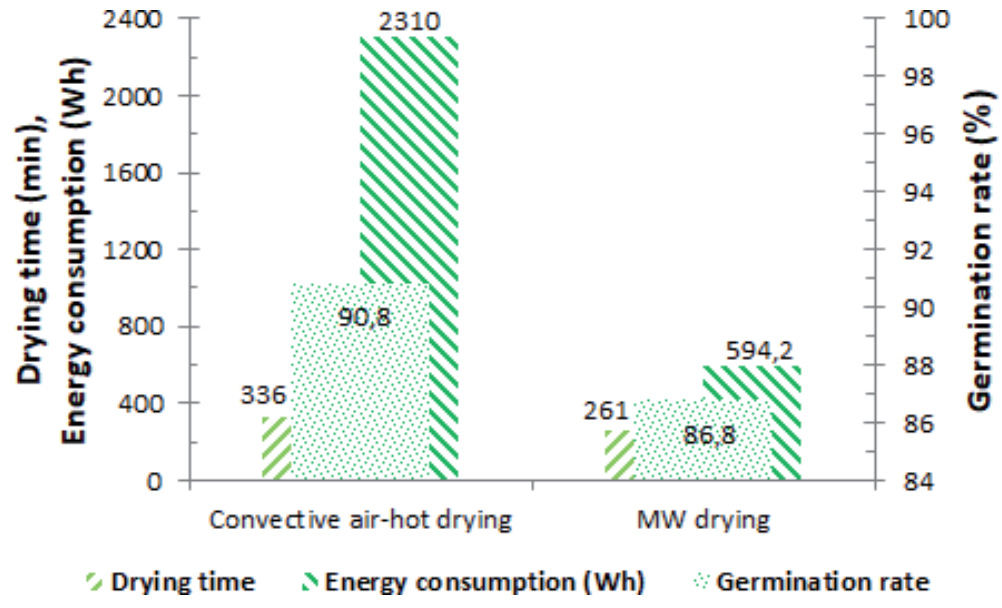

Figure 9.

Comparison of the microwave-assisted drying of amaranth seeds with hot air convection drying. 
In Figure 9, it can be observed that when the amaranth seeds are dried with microwave energy, there is a simultaneous reduction in drying time, energy consumption, and germination rate of the seeds compared to drying by hot air convection. The decrease in energy consumption ( 74\%) and drying time ( $22 \%)$ is considerable, making the microwave drying process much more competitive by reducing its operating costs. Moreover, the decrease in the germination rate of the seeds is small, $<5 \%$, so that the viability of the seeds is not significantly affected by microwave drying. These results show that microwave technology is a much faster and more efficient method than convection drying with hot air without affecting seed viability.

\section{Future prospects}

The results presented show the culmination of the phase I of the Program for Improvement and Selection of Amaranth in Cotopaxi (PROMAC). With the information obtained, it could, on the one hand, to determine which varieties, of the eight studied, have a greater adaptive potential, and, on the other hand, it was possible to verify that the drying strategy assisted by microwave energy can be a useful tool for the improvement of postharvest processes. However, there are still some issues to be resolved that will be addressed in phase II of the program. At this stage, the agronomic aspects (photoperiod, suitable soil type, and water requirements) to improve the crop will be addressed. In addition, biochemical (vitamin C content, among others) and nutritional studies will be carried out to know if these contents have been modified with adaptation strategies.

Regarding the improvement of the drying process of the amaranth seed, the established line of work aims to define more precisely what drying temperature range is ideal for optimizing seed conservation. Besides, the drying process for seeds from different varieties of amaranth will be evaluated to determinate the optimal drying conditions for conservation purpose. Physic-chemical and nutritional properties will also be evaluated after drying to figure out the effect of microwave energy on them. If the results performed at the laboratory scale were favorable, large-scale tests will be also carried out.

Finally, strategic alliances with other institutions in Ecuador and abroad will be developed, in order to carry out a characterization of the amaranth crops present in the country, so that the morphotypes can be determined and develop the different banks of germplasm for the conservation of the different varieties.

\section{Conclusions}

The preliminary results of the adaptation strategies for amaranth species confirm the capacity of the species to adapt, regardless of the origin of the material.

Based on the time to reach the maturity, the promissory species are those from USA and Argentina (Amaranthus sp. and A. hypochondriacus, respectively).

Although there are clear differences between the different collections of samples, the results of this study suggest that the species could be adapted to satisfy different requirements. For example, the species native to France (A. cruentus), Argentina (A. hypochondriacus), and Mexico (Amaranthus sp.) could be the most optimal for White-Grained Vegetable Improvement, taking into account that in Ecuador only one variety has been registered and released so far (INIAP-Alegría).

Likewise, the species from Belgium (A. caudatus) could serve as a decorative plant, due to its striking fuchsia-colored inflorescence. 
Similarly, the leaves of the species native to Belgium (A. cruentus) could be used in the production of tea, since at a present in Ecuador sangorache (A. quitensis) is the only variety released for the consumption of leaf tea.

On the other hand, the results obtained related to the seed conservation strategies based on microwave technology indicate that:

Microwave power density exerts a significant influence on the drying process and the germination rate of the amaranth seeds. When the power density is increased, there is a simultaneous decrease in the drying time, energy consumption, and germination rate of the seeds. The highest germination rate $(78 \%)$ was obtained at the lowest power density studied $(0.875 \mathrm{~W} / \mathrm{g})$. For this reason, in order to obtain high germination rates, after the drying process, it is necessary to dry the seed at low power densities (i.e., $0.875 \mathrm{~W} / \mathrm{g}$ or lower).

The drying temperature also has a significant effect on the microwave drying process and the germination rate of amaranth seeds. An increase in the drying temperature causes a simultaneous decrease in the drying time $(\sim 40 \%)$ and energy consumption $(\sim 50 \%)$ required to dry the seeds. However, there is also an unacceptable decrease $(\sim 57 \%)$ in the germination rate of the amaranth seeds with the increase in drying temperature. For this reason, it is necessary to dry amaranth seeds at a temperature of $40^{\circ} \mathrm{C}$ in order to obtain high germination rates.

The microwave drying of amaranth seeds, at a temperature of $40^{\circ} \mathrm{C}$, could be a viable alternative to convective drying with hot air as this would lead to a reduction in the drying time of $22 \%$ and a saving of energy consumption of $78 \%$. This saving of time and energy would make the microwave drying process of amaranth seeds much more competitive owing to the decrease in operating costs. The results obtained in this study show that microwave technology, at controlled temperature, would be a quick and efficient method of drying amaranth seeds without affecting their viability.

The work carried out to date within the framework of the program PROMAC in Cotopaxi has yielded promising results, which will serve as guidelines to develop the phase II of the PROMAC program.

\section{Acknowledgements}

The financial support received from the Technical University of Cotopaxi for the project "Evaluation of the Microwave Drying Process of Seeds of Agricultural Interest for the Cotopaxi Province" (Ref. PI.EPSHMS.CIYA.2017) is greatly acknowledged. The authors also thank the Russian Federal Center for Scientific Research in Vegetables (VNIISSOK) and the Russian University of Friendship of Peoples (RUDN) for providing amaranth seeds and finally A. Larcos, B. Herrera and G. Jiménez for their contribution to the experimental work.

\section{Conflict of Interest}

The authors declare no conflict of interest. 
Adaptation Strategies and Microwave Drying of Amaranth Species with a High Nutritional... DOI: http://dx.doi.org/10.5772/intechopen.88843

\section{Author details}

Carlos J. Torres-Miño ${ }^{1}$, Rafael Hernández Maqueda ${ }^{1 *}$ and Ángel H. Moreno²

1 Faculty of Agricultural Sciences and Natural Resources, Technical University of Cotopaxi, Latacunga, Ecuador

2 Faculty of Engineering and Applied Sciences, Technical University of Cotopaxi, Latacunga, Ecuador

*Address all correspondence to: rafael.hernandez@utc.edu.ec

\section{IntechOpen}

(C) 2020 The Author(s). Licensee IntechOpen. This chapter is distributed under the terms of the Creative Commons Attribution License (http://creativecommons.org/licenses/ by/3.0), which permits unrestricted use, distribution, and reproduction in any medium, provided the original work is properly cited. (cc) BY 


\section{References}

[1] Peralta E, Mazón N, Murrillo A, Villacrés E, Rivera M, Subía C. Catálogo de variedades mejoradas de granos andinos: chocho, quinua y amaranto para la sierra ecuatoriana. Quito, Ecuador; Publicación Miscelánea Nº 151 Programa Nacional de Leguminosas y Granos Andinos: Estación Experimental Santa Catalina, INIAP; 2009. 24 p

[2] Martínez Salvador L. Seguridad alimentaria, autosuficiencia y disponibilidad del amaranto en México. Problemas Del Desarrollo. 2016;47(186):107-132. DOI: 10.22201/ iiec.20078951e.2016.186.55882

[3] Sauer JD. The grain amaranths and their relatives: A revised taxonomic and geographical survey. Annals of the Missouri Botanical Garden. 1967;54(2):103-137

[4] Sandoval AZ. Amarantos y Chías: Un Estudio etnohistórico. Tesis Profesional [thesis]. Etnohistoria: Escuela Nacional de Antropología e Historia. INAH; 1989. $147 \mathrm{pp}$

[5] Sauer JD. The grain amaranth: A survey of their history and classification. Annals of the Missouri Botanical Garden. 1950;37:561-616

[6] Rastogi A, Shukla S. Amaranth. A new millennium crop of nutraceutical values. Critical Reviews in Food Science and Nutrition. 2013;53:109-125

[7] Saubhik D. Amaranthus: A Promising Crop of Future. 1st ed. West Bengal, India: Springer Singapore; 2016. p. 208. DOI: $10.1007 / 978-981-10-1469-7$

[8] Weber E. Amaranth Grain Production Guide 1987. Emmaus, PE: Rodale Research Center Rodale Press Inc; 1987

[9] Chaudhari PP, Patel PT, Desai LJ. Effect of nitrogen managemente on yield, water use, and nutrient uptake on grain amaranth (Amaranthus hypocondriachus) under moisture stress. Indian Journal of Agronomy. 2009;54(1):69-73

[10] Orona-Tamayo D, Paredes López O. Chapter 15- Amaranth part 1-Sustainable crop for the 21st century: Food properties and nutraceuticals for improving human health. In: Nadathur SR, Wanasundara JPD, Scanlin L, editors. Sustainable Protein Sources. Massachusetts, USA: Academic Press; 2017. pp. 239-256

[11] Bressani R, Sánchez-Mallorquín A, Morales E. Chemical composition of grain amaranth cultivars and effects of processing on their nutritional quality. Food Reviews International. 1992;8(1):23-49

[12] Escudero NL, de Arellano ML, Luco JM, Giménez MS, Mucciarelli SI. Comparison of the chemical composition and nutritional value of Amaranthus cruentus flour and its protein concentrate. Plant Foods for Human Nutrition. 2004;59:15-21

[13] Nieto C. El cultivo de Amaranto Amaranthus spp una alternativa agronómica para el Ecuador. Quito, Ecuador; Publicación Miscelánea $\mathrm{N}^{\circ}$ 52: Estación Experimental Santa Catalina, INIAP; 1989. $24 \mathrm{p}$

[14] Peralta E, Villacrés E, Mazón N, Rivera M, Subía C. El ataco, sangorache o amaranto negro (Amaranthus hybridus L) en Ecuador. Quito: Ecuador; Publicación Miscelánea $N^{\circ}$ 143: Programan Nacional de Leguminosas y Granos Andinos. Estación Experimental Santa Catalina, INIAP; 2008. $55 \mathrm{p}$

[15] Valenzuela G. El despertar de los granos andinos. Gestion. 2014;237:38-41 
[16] Gins MS, Torres Miño C.

Characteristics of varieties of amaranth selection VNIISSOK on resistance to low temperature and drought during cultivation in the Moscow region and the republic of Ecuador. Vegetables of Russia. 2015;1:42-46

[17] Casa CR. Evaluación del comportamiento agronómico con la utilización de bioestimuladores de crecimiento orgánico en dos variedades de amaranto (Amaranthus spp) originarios de VNIISSOK (Rusia) para la producción de biomasa bajo cubierta, sector Lasso-Latacunga-Cotopaxi 2016 [thesis]. Universidad Técnica de Cotopaxi; 2016

[18] Guanoluisa Heidi Y. Evaluación de tres abonos orgánicos en dos variedades de amaranto (Amaranthus spp) originarios de VNIISSOK - Rusia, para la producción de semilla en el barrio Patután - provincia Cotopaxi, 20152016 [thesis]. Universidad Técnica de Cotopaxi; 2016

[19] Mujica A. El cultivo de amaranto (Amaranthus spp): Producción mejoramiento genetico y utilizacion. Puno: FAO; 1997

[20] Torres Miño C. Evaluación de variedades de amaranto con la utilización de métodos químicos y moleculares para la obtención de productos funcionales en bases a la biomasa. Moscú-Rusia: Universidad Rusa de la Amistad de los Pueblos. [doctoral thesis]. Universidad Rusa de la Amistad de los Pueblos; 2015

[21] Tosi EA, Ré ED. Amaranth grain drying in a fluidized bed. Drying Technology. 1999;17:909-914. DOI: 10.1080/07373939908917578

[22] Moreno ÁH, Hernández Maqueda R, Ballesteros I. Microwave drying of seeds and vegetable products: A viable option for Ecuador. In: Fayos-Fernández J, Monzó-Cabrera J, editors. Proceeding of the 3rd Global Congress on Microwave Energy Applications (3GCMEA). Cartagena: CRAI Biblioteca, Universidad Politécnica de Cartagena; 2016. pp. 103-108

[23] Moreno ÁH, Hernández Maqueda R, Ballesteros I. Microwave drying of seeds of agricultural interest for Ecuador.

AMPERE Newsletter. 2017;

92:28-32

[24] Moreno ÁH, Hernández Maqueda R, Ballesteros I. Secado industrial con energía microondas. In: Menéndez JA, Moreno ÁH, editors. Aplicaciones Industriales del Calentamiento con Energía Microondas. 1st ed. Latacunga: Universidad Técnica de Cotopaxi; 2017. pp. $85-118$

[25] Barrozo MAS, Mujumdar A, Freire JT. Air-drying of seeds: A review. Drying Technology. 2014;32:1127-1141. DOI:

10.1080/07373937.2014.915220

[26] Bala BK. Drying and Storage of Cereal Grains. 2nd ed. Wiley-Blackwell: Chichester; 2017. 333 p

[27] Bern CJ, Quick G, Herum FL. Harvesting and postharvest management. In: Serna-Saldivar SO, editor. Corn. Chemistry and Technology. 3rd ed. Oxford: AACC International Press; 2019. pp. 109-145. DOI: 10.1016/ B978-0-12-811971-6.00005-X

[28] Mossman AP, Miller GE. A review of basic concepts in rice-drying research. CRC Critical Reviews in Food Science and Nutrition. 1986;25:49-71. DOI: $10.1080 / 10408398609527445$

[29] Sokhansanj S, Aaghavan GSV. Drying of grains and forages. A brief review of recent advances. Drying Technology. 1996;14:1369-1380. DOI: $10.1080 / 07373939608917150$

[30] Chongwen C. The current situation of grain drying in China. 
Drying Technology. 1998;17:1759-1766. DOI: 10.1080/07373939908917650

[31] Shukla BD. Drying technology and equipment in India. Drying Technology. 2001;19:1807-1824. DOI: 10.1081/ DRT-100107274

[32] Fudholi A, Sopian K, Ruslan MH, Lghoul MA, Sulaiman MY. Review of solar dryers for agricultural and marine products. Renewable and Sustainable Energy Reviews. 2010;14:1-30. DOI: 10.1016/j.rser.2009.07.032

[33] El-Sebaii AA, Shalaby SM. Solar drying of agricultural products: A review. Renewable and Sustainable Energy Reviews. 2012;16:37-43. DOI: 10.1016/j.rser.2011.07.134

[34] Delele MA, Weigler F, Mellmann J. Advances in the application of a rotary dryer for drying of agricultural products: A review. Drying Technology. 2015;33:541-558. DOI: 10.1080/07373937.2014.958498

[35] Sivakumar R, Saravanan R, Elaya Perumal A, Iniyan S. Fluidized bed drying of some agro products - A review. Renewable and Sustainable Energy Reviews. 2016;61:280-301. DOI: 10.1016/j.rser.2016.04.014

[36] Lamidi RO, Jiang L, Pathare PB, Wang YD, Roskilly AP. Recent advances in sustainable drying of agricultural produce: A review. Applied Energy. 2019;233-234:367-385. DOI: 10.1016/j. apenergy.2018.10.044

[37] Calzetta Resio AN, Aguerre RJ, Suarez C. Drying characteristics of amaranth grain. Journal of Food Engineering. 2004;65:197-203. DOI: 10.1016/j.jfoodeng.2004.01.015

[38] Abalone R, Gastón A, Cassinera A, Lara MA. Thin layer drying of amaranth seeds. Biosystems Engineering. 2006;93:179-188. DOI: 10.1016/j. biosystemseng.2005.11.010
[39] Abalone R, Cassinera A, Gastón A, Lara MA. Some physical properties of amaranth seeds. Biosystems Engineering. 2004;89:109-117. DOI: 10.1016/j.biosystemseng.2004.06.012

[40] Kassen AS, Shokr AZ, El-Mahdy AR, Aboukarima AM, Hamed EY. Comparison of drying characteristics of Thompson seedles grapes using combined microwave oven and hot air drying. Journal of the Saudi Society of Agricultural Sciences. 2011;10:33-40

[41] Motevali L, Minaei S, Khoshtaghaza MH, Amirnejat H. Comparison of energy consumption and specific energy requirements of different methods for drying mushroom slices. Energy. 2011;36:6433-6441. DOI: 10.1016/j.energy.2011.09.024

[42] Schiffmann RF. Microwave and dielectric drying. In: Mujumdar AS, editor. Handbook of the Industrial Drying. 4th ed. Boca Raton: CRC Press; 2014. pp. 283-302

[43] Rattanadecho P, Makul N. Microwave-assisted drying: A review of the state-of-the-art. Drying Technology. 2016;34:1-38. DOI: 10.1080/07373937.2014.957764

[44] Vadivambal R, Jayas DS. Changes in quality of microwave-treated agricultural products - a review. Biosystems Engineering. 2007;98:1-16. DOI: 10.1016/j.biosystemseng.2007.06.006

[45] Brodie G. Applications of microwave heating in agricultural and forestry related industries. In: Cao W, editor. The Development and Application of Microwave Heating. 1st ed. Rijeka: IntechOpen; 2012. pp. 45-78. DOI: $10.5772 / 45919$

[46] Feng H, Yin Y, Tang J. Microwave drying of food and agricultural materials: Basics and heat and mass transfer Modeling. Food Engineering 
Reviews. 2012;4:89-106. DOI: 10.1007/ s12393-012-9048-x

[47] Zhang M, Chen H, Mujumdar AS, Tang J, Miao S, Wang Y. Recent developments in high-quality drying of vegetables, fruits, and aquatic products. Critical Reviews in Food Science and Nutrition. 2017;57:1239-1255. DOI: $10.1080 / 10408398.2014 .979280$

[48] Kemp IC. Fundamentals of energy analysis of dryers. In: Tsotsas E, Mujumdar AS, editors. Modern Drying Technology Volume 4: Energy Savings. 1st ed. Weinheim: Wiley-VCH Verlag GmbH \& Co. KGaA; 2012. pp. 1-45. DOI: 10.1002/9783527631681.ch1

[49] Strumiłło C, Jones PL, Żyłła R. Energy aspects in drying. In: Mujumdar AS, editor. Handbook of the Industrial Drying. 4th ed. Boca Raton: CRC Press; 2014. pp. 1077-1100

[50] Barbosa de Lima AG, da Silva JV, Pereira EMA. Drying of bioproducts: Quality and energy aspects. In: Delgado JMPQ, Barbosa de Lima AG, editors. Drying and Energy Technologies. 1st ed. Cham: Springer International Publishing Switzerland; 2016. pp. 1-18. DOI: 10.1007/978-3-319-19767-8_1

[51] ISTA. The germination test. In: The International Seed Testing Association (ISTA) Ed. International Rules for Seed Testing 2017. Bassersdorf: International Seed Testing Association (ISTA); 2017. pp. 51-56. DOI: 10.15258/ istarules.2017.05

[52] FAO. Seeds in Emergencies: A Technical Handbook. 1st ed. Rome: Food and Agriculture Organization of the United Nations; 2010.73 p. ISBN 978-92-5-106676-8

[53] Hernández Maqueda R, Ballesteros I, Jiménez Jácome $\mathrm{S}$, Moreno ÁH. Microwave drying of amaranth and Quinoa seeds: Effects of the power density on the drying time, germination rate and seedling vigour. The Journal of Microwave Power and Electromagnetic Energy. 2018;52:299-311. DOI: 10.1080/08327823.2018.1534052

[54] Shivhare U, Raghavan V, Bosisio R, Giroux M. Microwave drying of soyben at 2.4 Ghz. The Journal of Microwave Power and Electromagnetic Energy. 1993;28(1):11-17

[55] Nair GR, Li Z, Gariepy Y, Raghavan V. Microwave drying of corn (Zea mays L. ssp.) for the seed industry. Drying Technology. 2011;29(11):1291-1296

[56] Manickavasaga A, Jayas D, White N. Germination of wheat grains from uneven microwave heating in an industrial microwave dryer. Canadian Biosystems Engineering. 2007;49(3):23-27

[57] Moreno ÁH, Hernández Maqueda R, Ballesteros I, Torres-Miño C. Microwave drying of corn seeds: Effect of temperature on drying time, energy consumption and germination rate. In: Paper to be Presented at 17th International Conference on Microwave and High Frequency Heating. Valencia, Spain: AMPERE; 2019 



\title{
Chapter 3
}

\section{Value of Amaranthus [L.] Species in Nigeria}

\author{
Matthew Chidozie Ogwu
}

\begin{abstract}
This chapter addresses the value of different Amaranthus [L.] species that have been recorded in Nigeria. These are Amaranthus blitum, $A$. dubius, A. caudatus, $A$. cruentus, $A$. deflexus, A. graecizans, $A$. hybridus, A. hypochondriacus, A. retroflexus, A. spinosus, $A$. thunbergii, $A$. tricolor and $A$. viridis. Although they are mostly cultivated, some are present as weeds and others are valued for their ornamental roles. Amaranthus species are the most important vegetables in some parts of Nigeria because of their leaves, succulent stem and cereal-like grains. The chapter describes their socio-cultural (ethnobotanical), ecological, economic, food and income security values as well as their production requirements. Although amaranths are stress tolerant, mesic condition and soil enrichment can increase output and nutrient composition, respectively. This work revealed that a gap exists in annual production amounts and foreign exchange earning from amaranths. It also compared the 13 species based on their proximate and phytochemical composition. Amaranths are already contributing to sustainable development and livelihood in Nigeria without established institutional support. There is a need for Nigeria to establish a vegetable centre (with the proposed name: Nigerian Vegetable Center) to maximise the potential and actual values of amaranths and other vegetable species in Nigeria.
\end{abstract}

Keywords: Amaranthus, leafy vegetables, food security, plant-based medicine, plant diversity, Ethnobotany, food value, environmental roles, income security, Nigerian Vegetable Center

\section{Introduction}

Global vegetable cultivation and consumption continue to witness a global expansion that is greater than any other plant group [1]. This is connected to their valued phytochemical contents and the diversity of plant species that can be exploited for their fruits, flowers, tubers or leaves as vegetables. Moreover, technological advancements have made their production more attractive due to less disease incidence and pest attacks. Together, these have led to increased food and income security value for vegetables. They are now considered as key contributors to the pursuit of sustainable development especially in third world countries like Nigeria where they are cheap sources of vital nutrients and energy as well as a means to improve income equality and employment.

There is no universally accepted definition for vegetables but they are generally plants that are valued for their leaves, stems, young shoots, fruits or a combination of these plant parts, which may be used to fulfil human needs [2]. Vegetables may be 
annual, biannual or perennial with variable growth requirements depending on the environmental conditions, species, and the geographical origin and distribution. The number of plants exploited as vegetable globally is unknown but it is estimated that over 1 billion tonnes of vegetables are gathered each with China and India accounting for a bulk of that amount as the world largest producers of vegetables. Even though certain vegetables are not easily available in some parts of the world, most are accessible and affordable [3]. Based on availability and nutritional composition tomato, curcubits, alliums and chillies are considered the most important vegetables in the world [4]. Although the information on some indigenous vegetable consumed in a few countries or restricted to third world countries is hard to come by and often not put in a global perspective for the sake of comparison. For instance, weed in one part of the world may be considered an essential vegetable in another.

The benefits of consuming vegetables remain the focus of many research and public health nutrition education because, in all societies and ethnic groups, vegetables are consumed irrespective of socio-economic status [5, 6]. Low consumption of vegetable may cause disability, lower lifespan and death. Whole or parts of mature or immature vegetables may be eaten raw (fresh or dried), cooked or in other processed forms (e.g. as oil) and used as a part of other food for different purposes including as a source of energy, nutrition, flavour, colouring or medicine. In part of sub-Saharan Africa, vegetables are a cheap and reliable source of proteins, vitamins, zinc and iron as well as a source of income for the mostly female farmers [7]. Due to insufficient consumption, some countries have developed dietary recommendations with respect to vegetable consumption as a way to promote healthy living and disease prevention [3, 8]. The report of Alberta Health Services [9] suggests that poor people or people with lower household income consume more vegetables.

Socio-cultural and economic activities related to vegetables have evolved over time in many parts of the world. According to Sinha et al. [10], the impacts of the food industry on the global economy relies upon the increased consumption and processing of fresh and processed vegetables. Moreover, Schreinemachers et al. [4] proposed a greater value for vegetable production than all cereals combined despite a relatively low level of support from private, national and international donors compared to staple and oil crops. At the national level, many countries continue to earn huge foreign exchange from vegetable related activities. Moreover, vegetable accounts for a huge percentage of food waste and require millions of dollars to manage [11]. In Nigeria, large-scale cultivation of vegetable is rare as they are mostly cultivated in small farms and in home gardens. In addition, numerous biotic and abiotic factors militate vegetable production and consumption [12], which are heightened by limited global effort as compared to other groups of economic plants.

The objective of this chapter is to outline the values of Amaranthus [L.] spp. in Nigeria from different perspectives including comparing their phytochemical compositions, ethnobotanical (socio-cultural) roles, ecology, production requirements, food and income importance. This chapter presents a list of Amaranthus spp. in Nigeria and seeks to highlight their importance with a view to promoting their consumption and use. Through comparing their phytochemical composition, this chapter will highlight the contributions of these amaranths to food and nutrition security while recommending their production as an economic opportunity for reducing poverty and unemployment. Amaranths are considered the most widely consumed and traded green vegetable in sub-Saharan Africa because of their soft texture and mild flavours [13]. Typical of vegetables, Amaranthus species have a peculiar requirement for their production and this will be addressed from the seed sources, soil and climatic requirements, management practices, harvesting, storage and transportation perspectives. The section on ethnobotany will discuss the socio-cultural relevance of the plant group across the diverse ethnic groups in 
Nigeria. The final part of this chapter presents some recommendations with regards to how to maximise the benefits of these plant genetic resources such as the need for production support, research and data management as well as a proposal to establish a national vegetable centre in Nigeria.

\section{Amaranthus species in Nigeria}

Amaranthus (Amaranthaceae) is a cosmopolitan genus found both in temperate and tropical regions of the world with ca. 70 species and ca 400 varieties. This diversity is greater than most highly cultivated crops despite the underdeveloped and relatively lack of support [14]. Southern Asia (Indo-Burma region) and Central and South America are considered the centre of origin for most of the varieties that have been held under cultivation since time immemorial [15-18]. Spread to other parts of the world likely began with colonisation and exploration. Wild species still occur in parts of Asia, Africa and America. Most amaranths are classified either as a leafy or grain (pseudocereal) amaranth based on the part that is most often used, i.e. edible seeds or leaves [19]. Examples of leafy and grain amaranths are $A$. tricolor $\mathrm{L}$. and $A$. cruentus $\mathrm{L}$. respectively. In addition, some amaranth like $A$. tricolor is valued as ornamental, while $A$. palmeri $\mathrm{S}$. Wats. is considered a weed of economic importance. Because of their huge genetic and morphological variability, they are considered a taxonomically difficult group.

Osawaru et al. [20] included amaranths in a list of common plants used in Nigeria. Based on an extensive literature review, thirteen species of Amaranthus were found to have been documented as commonly found in Nigeria under cultivation, as weeds or ornamental. These are A. blitum L. (syn. A. lividus L.), A. dubius Mart. Ex Thell., A. caudatus L., A. cruentus L., A. deflexus L., A. graecizans L. (Basionym A. silvestris Vill.), A. hybridus L., A. hypochondriacus L., A. retroflexus L., A. spinosus L., A. thunbergii Moq., A. tricolor L., and $A$. viridis L. None of the thirteen species is native to Nigeria but most have since acclimatised to the clime and are valued for their leaves, herbaceous stem, inflorescence, seeds and chemical byproducts.

A. blitum (common names in English include amaranth, wild amaranth, pigweed, purple amaranth) syn. A. lividus $\mathrm{L}$. is a cultivated species that also occur as harvestable ruderals in Nigeria due to the leaves (Figure 1). Likely introduced to Nigeria from the Mediterranean and Arabian region where it is native. It occurs widely as a weed across Nigeria. Botanically the plant is an annual, with glabrous, ascending to prostrate, sometimes erect, simple or branched stem that grows up to 6-90 cm. Leaves are ovate or obovate with tapering or cuneate base. Slender terminal spikes or panicle inflorescence. A. blitum have shiny black seeds but are appreciated for the soft stems and sweet tasting green or red leaves.

A. caudatus (common names in English include red amaranth, flower amaranth and pendant amaranth) is found mostly in Southern Nigeria (Figure 1). This is a grainy amaranth. The grains vary in colour from white to brown to red. They are valued as ornamental due to their impressive red inflorescence, which is dense spikes. The plant can grow up to $160 \mathrm{~cm}$ and is sun-loving. It is considered a weed or ornamental in Nigeria but the leaves are edible. Red coloured flowers are the most common flower colour-variant in Nigeria. The plant is native to the Americas.

A. cruentus (common English names include amaranth, African spinach, red amaranth, and purple amaranth) is the globally popular grain amaranth (considered a pseudocereal) albeit not widely cultivated in Nigeria (Figure 1). ParedesLopez and Hernandez-Lopez [33] reported that $A$. cruentus takes approximately 44 days to flower (at $60 \mathrm{~cm}$ ) and can be harvested from 102 days (at $125 \mathrm{~cm}$ ). It is native to the Americas. In Nigeria, they are valued for their ornamental properties than for their seeds. They are common as weeds, especially around urban centres. It 


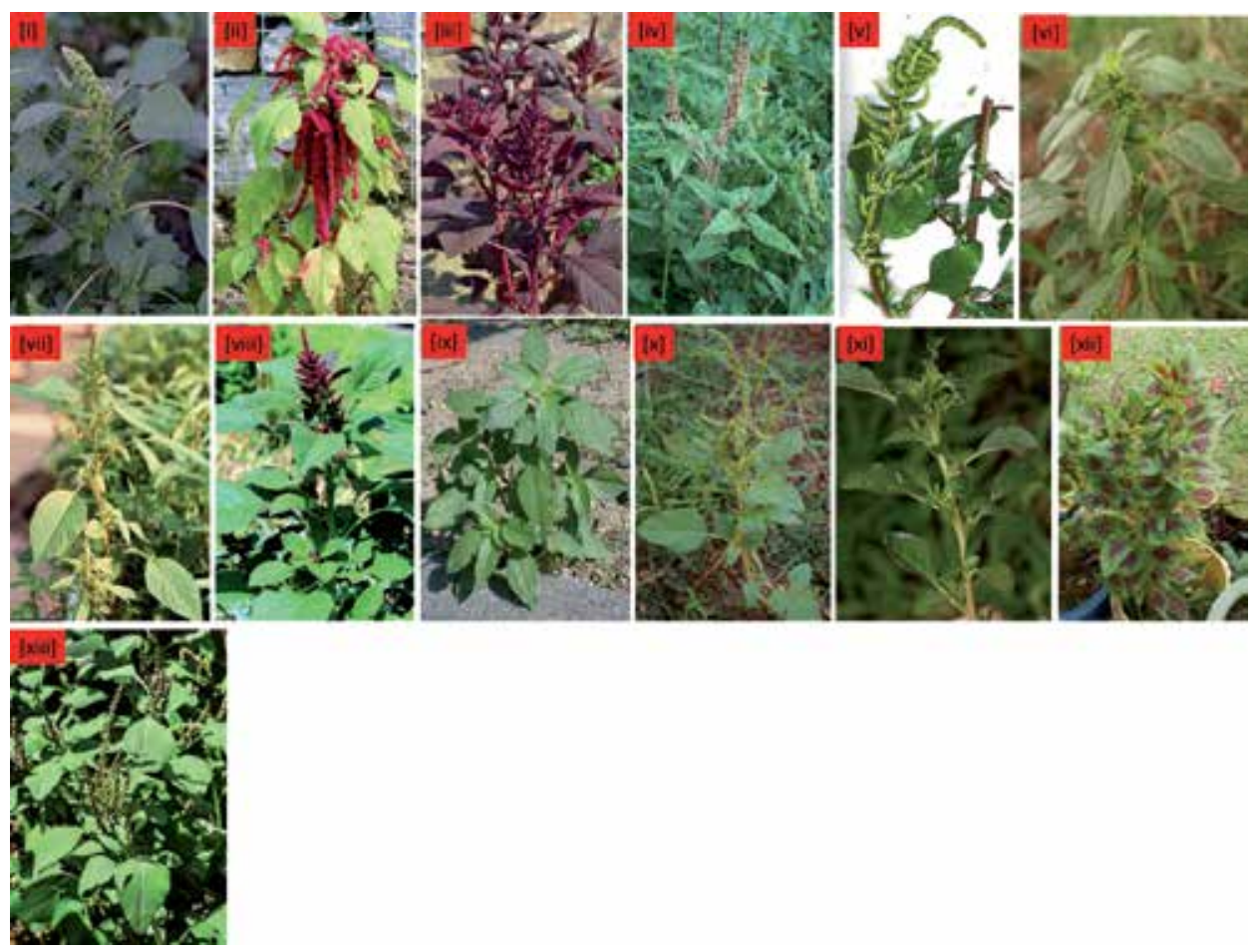

Figure 1.

The common amaranth species in Nigeria are: $i$. A. blitum, ii. A. caudatus, iii. A. cruentus, $i v$. A. deflexus, $v$. A. dubius, vi. A. graecizans, vii. A. hybridus, viii. A. hypochondriacus, $i x$. A. retroflexus, $x$. A. spinosus, xi. A. thunbergii, xii. A. tricolor and xiii. A. viridis. Source: adapted from [21-32].

shares key morphological characters with $A$. hybridus. The grains are dark-red with green spots in colour while the long stems bear a large inflorescence likely introduced by Europeans.

A. deflexus (amaranth, pigweed and green are the English common names in Nigeria) is a cultivated species in parts of Central and Southern Nigeria [34]. Botanically, A. deflexus is an annual or perennial herb (when outside cultivation) with slender to rather stout stem that can grow up to $80 \mathrm{~cm}$ with varied coloured multicellular hairs, moderate to dense leaves, green flowers that is slender and lax to stout and dense terminal and axillary spikes and compressed-ellipsoid seed (Figure 1) [35]. It is native to Asia and South America. Seeds of A. deflexus are large compared to other Amaranthus species.

A. dubius (common names in English include amaranth, spleen amaranth, green, green spinach, and pigweed): Likely introduced to Nigeria by early European visitors. The plant is annual, erect, herbaceous dicot with a branched stem that grows up 30-150 cm with spike-like or paniculate inflorescence and broad leaves (Figure 1). A. dubius does well in diverse soil and climatic condition. Hence, it is cultivated in Southern and Northern parts of Nigeria for the edible leaves, seeds and stems where it occurs as a ruderal. The ruderal ones are also harvested and consumed. Fast growing and high yielding plant with distinctive dark-green, broad, ridged palatable leaves.

A. graecizans (common names in English include wild amaranth, prostrate amaranth, and spreading pigweed) is a cultivated annual in Nigeria (but also remains as a weed) and the leaves are eaten as vegetables and used as livestock feed. The prostrate or decumbent plant can grow up to $50-150 \mathrm{~cm}$ in height (Figure 1). It is native to the warm temperate regions and very common in eastern parts of Africa. 
A. hybridus (common name in English include green, amaranth, pigweed, slim amaranth, and green leaf) is very diverse (in colour and size) in Nigeria including weedy cultivars. Can grow up 15-150 cm (Figure 1). The leaves are green with red blotches. The lower side of the leaf has prominent pinnate veins. The plant prefers mesic to dry conditions. The plant has a long history of cultivation in Nigeria. It begins to flower at $65 \mathrm{~cm}$ (after approximately 57 days) and is ready for harvest after 129 days at approximately $180 \mathrm{~cm}$ [33].

A. hypochondriacus (common English name include Prince's feather and amaranth) is a common ornamental and weedy species in Nigeria whose leaves are also consumed. The plant is considered a pseudocereal as it is a grainy species of Amaranthus. Early European visitors likely introduced it to Nigeria from the Americas. The plant can grow up to $4-200 \mathrm{~cm}$. The plant begins to flower at 43 days and is ready for harvest after 100 days (Figure 1) [33]. The fruit is obovoid to rhombic capsule with whitish to yellowish or blackish seeds.

A. retroflexus (common English names include amaranth, pigweed, and tumbleweed) is an introduced species common amaranth in irrigated farmlands in Northern Nigeria. The species also occur as a ruderal in parts of central Nigeria. The leaves are eaten as part of salads or used with other condiments in soups. The plant can grow up to $30 \mathrm{~cm}$. Botanically the plant is a monoecious, annual herb with tap roots and erect stem (freely branched), leaves range between 0.8 and 3.9 inches and inflorescences are densely crowded (Figure 1) [36].

A. spinosus (common names in English include Nigerian thorn, spiny amaranth, prickly amaranth, and spiny pigweed) is a thorny weed common as ruderals as well as in the wild (Figure 1). The leaves are consumed in different parts of Nigeria and used as livestock feed. Native to the Americas and introduced to Nigeria. Stems and leaves are hairless, sometimes shiny in appearance and the leaves characteristically have rigid, sharp spines of variable sizes [37].

A. thunbergii. (common English names include wild amaranth, wild spinach, and pigweed) is a popular species in Northern Nigeria that is used for flavouring food. The leaves are also valued as food. Plants can grow up to $55 \mathrm{~cm}$. The stem is hairless, simple or branched, angular but with hairs towards the top (Figure 1). Flowers are greenish in short axillary clusters, and unisexual [38]. The fruit is an ovoid-ellipsoid to the pyriform capsule. The species is native to Africa but introduced to Nigeria.

A. tricolor (common name in English are amaranth, Chinese spinach, and Joseph's coat) is a multi-coloured species of amaranth often yellow, red and green (Figure 1). The plant is valued as an ornamental as well as edible leaves and stems in Nigeria. It is native to the old world tropics that can grow up to $125 \mathrm{~cm}$ in moist and mesic soil conditions. The plant can tolerate hot summer conditions [39]. The flowers are non-showy.

A. viridis (common English names include green amaranth, local tote, and African spinach) is a highly branched amaranth with edible ovate, long leaves (Figure 1). The plant can grow up to $60-80 \mathrm{~cm}$. In Nigeria, A. viridis is a common weed that is also found under cultivation across the country. Among the weedy amaranths in Nigeria, A. viridis is most the consumed [40]. The plant is native to East Asia.

\section{Ethnobotany of amaranths found in Nigeria}

Local knowledge, utilisation, and practices (including superstitious cultures) that have evolved over the years with regards a specific plant is regarded as ethnobotany [41-44]. Most amaranth is believed to have originated from America where the Aztec and Inca scripts show early utilisation but the exact date of introduction 
to Nigeria remains unclear. However, Nigerians have interacted with Amaranthus spp. for many centuries resulting in different cultural practices and beliefs that have locally sustained the germplasm and endeared it to the people. Some of the diverse ethnic groups in Nigeria call almost all the varieties with the same local name like shokoyokoto, efo, tete, arowo jeja (Yoruba), Akwukwo, inene (Igbo), Boroboro (Fulani), and Alaiyaho (Hausa). Indigenous people consider most of the amaranth species available in their vicinity as the same [45]. They serve multipurpose ethnological roles as medicines, dyes, home decorators, animal feed, human food, and superstitious practices to local gods. Dried, ground Amaranthus parts are used to produce local drugs which may be consumed alone or mixed with water or added to local soups.

The plant is used in medicines in the treatment of eye, ear, and stomach troubles as well as for dysentery, diarrhoea, diuretics, lactation boost, anus, haemorrhoids, menstrual cycle, venereal diseases, paralysis, epilepsy, convulsion, and spasm [45]. According to Alegbejo [46], it was reported that boiled leaves and roots of Amaranthus spp. are used as a laxative, diuretic, anti-diabetic, antipyretic, antisnake venom, antileprotic, anti-gonorrhoeal, expectorant, to relieve breathing in acute bronchitis due to their anti-inflammatory properties, immunomodulatory activity, anti-androgenic activity and anthelmintic properties. It is a common belief in South Eastern parts of Nigeria that the consumption of amaranth leaves and stem in the soup will boost blood count and revitalise the body. In the same region, hot amaranth soup served with fish is often prepared for nursing mothers to boost their immunity. In the South Western region of Nigeria, consumption of fresh (uncooked) but mature amaranth leaves is used in the treatment of mouth and stomach ulcers. In some parts of Northern Nigeria, the red inflorescence is used to make dyes as well as a traditional drink for stomach pains. In North Central parts of Nigeria, amaranth extract is applied to boils until the purse is discharged and the wet plan is tied to Whitlow as it helps it to dry up faster [47].

Juice of $A$. blitum can be used in the treatment of buccal and throat ulcers and headaches. Common weedy species $A$. viridis is consumed by humans and their livestock as a medical remedy [40]. A. blitum is used in the treatment of lung disorders as well as an astringent against ulcers and as a cooling lotion to ease urinary troubles and bile [48]. A. spinosus root is used as part of skin lotion while the whole plant is used to treat snakebite, diabetes, gonorrhoea and as an antihelmintic [49]. A. spinosus root is used as part of skin lotion while the whole plant is used to treat snakebite, diabetes, gonorrhoea and as an antihelmintic [49]. Amaranths are used as a body lotion to treat skin infections like eczema and pimples. The young succulent stems are boiled and mixed with honey as a laxative. Amaranths seeds are roasted and used in making different local alcoholic and no alcoholic beverages [50]. According to Soladoye et al. [51], A. spinosus has a role in female fertility as a mixture produced with the plant can be used to wash both breasts once or twice a day for seven days. The same plant was suggested by Soladoye et al. [51] to be vital in the traditional management of diabetes. In superstitious practices, the plant is offered alongside other gifts to guardians of local deities. The leaves are used to dress wounds.

\section{Production requirements of amaranths in Nigeria}

Amaranths are mostly annual fast growing herbs that are mostly cultivated on lowlands especially the leafy species. Cultivation is not restricted to distant farms, Riverside, and home gardens as some families maintain some plants in small pots inside the house. Generally, amaranths are fast growing and can be ready for harvest within weeks. Farmers prefer certain species to others depending on the part of 
Nigeria; parts valued in that region and intended use. Although they are typically short-lived (with few perennials), they are known to tolerate diverse growth environments including harsh ones. This is likely due to their anatomical characteristics, a well-formed root system, stomatal conductance, and maintenance of leaf area, which together increases the efficiency $\mathrm{CO}_{2}$ utilisation under temperatures, higher light intensity and moisture stress [52].

Seeds are often cultivated directly in the soil as sole crops on beds or intercropped with other crops initially on a nursery bed and later transplanted after 2-3 weeks [53]. Land preparation and raised beds (of about $90 \mathrm{~cm}$ wide and $20 \mathrm{~cm}$ high) and covering sown seeds with a thin layer of compost or rice hulls ensure good germination and growth [54]. The optimum temperature for the germination of amaranth seeds is $16-35^{\circ} \mathrm{C}$. However, post germination, they are known to tolerate temperature, water and nutrient stress. Nonetheless, growth is best under mesic conditions including soil with good water retention capacity, slightly acidic or alkaline $\mathrm{pH}$ and sufficient rainfall or water supply. Harvesting begins 4-5 weeks after planting. Alonge et al. [55] reported that Amaranthus spp. in Nigeria grows best with $500 \mathrm{~kg} \mathrm{ha}^{-1}$ NPK treatment at 4 and 5 WAP and from $250^{2} \mathrm{~kg} \mathrm{ha}^{-1} \mathrm{NPK}$ treatment at 6 and 7 WAP whereas $250^{1} \mathrm{~kg} \mathrm{ha}^{-1} \mathrm{NPK}$ application can result in slightly higher values in growth parameters than $125 \mathrm{~kg} \mathrm{ha}^{-1}$ at 4 and 5 WAP. Oyedeji et al. [34]; Ufoegbune et al. [56] and Dada et al. [57] corroborate their results about the relevance of different soil amendment. Hence, the environment and soil condition in which amaranths are cultivated in Nigeria influence their performance. The soil amendments can be directed to influence certain desired growth features.

Generally, different species of amaranths show a preference for seed burial depth and duration of seed burial with an average of $0.5-4 \mathrm{~cm}$ and 9 months to 40 years respectively [52]. Amaranths may be ready for harvesting approximately $3-5$ weeks after cultivation. Harvesting is done by cutting leaves by hand or uprooting or cutting stems close to the ground level. Harvested seeds, leave or shoots are bundled, the roots are washed and used domestically or packed and transported to industries or market. In the markets and shops, amaranths leaves are sprinkled with water to keep a fresh appearance or held in open containers with the roots in the water [58]. Seeds may be stored in moisture-free environment held in different materials.

\section{Ecological and economic importance/value of amaranths in Nigeria}

According to NRC [13] cultivation of amaranths contributes to the vitality of farmlands as they used as pioneer species for the colonisation of disturbed lands. This characteristic is partly attributed to their C4 mode of photosynthesis, which involves efficient water use. They are photoperiod sensitive and are known to flower during shorter day lengths [54]. Their ability to grow in nutrient-poor soil is also of ecological importance. The allelopathic effect of different plant species on their production range from negative effects on chlorophyll, number of leaves stem length and dry matter (in A. hybridus), decrease growth and productivity (in $A$. viridis), reduced vegetative and reproductive phase (in $A$. spinosus), and decreased chlorophyll content, nitrogen fixation, respiration, growth, nutrient uptake, and germination (in A. retroflexus) [52].

Although members of the Amaranthus genus are not poisonous they are known to accumulate nitrates in their leaves when cultivated in nitrogen-rich soils and can cause stomach cancer [59]. Environmental pollution poses a risk to amaranth consumption in Nigeria. This was enumerated in Ogunkunle et al. [60] where they suggested potential human absorption of lead, cadmium and zinc through 
the consumption of amaranths that have bioaccumulated these harmful metals. Vwioko et al. [61] also showed that high concentrations of $\mathrm{SO}_{2}$ and $\mathrm{NO}_{2}$ induce stress (biochemical) and morphological response from amaranths. Thus, they can be used to indicate levels of environmental pollutions, especially in urban centres. Phytoremediation of some heavy metal contaminated sites by Amaranthus species has been reported and the mechanism includes the removal by translocation of the heavy metal to aerial parts of the plant from the soil. It has been established that amaranths are viable phytoaccumulators of heavy metals including $\mathrm{Cu}, \mathrm{Zn}, \mathrm{Cr}, \mathrm{Pb}, \mathrm{Cd}$, $\mathrm{Hg}, \mathrm{Mn}, \mathrm{Ni}, \mathrm{Zn}$, and Fe and applied in phytoremediation of contaminated sites [52].

Production of Amaranths in Nigeria is low and falls short of demands despite cultivation acquiring increasing importance in parts of Nigeria where the available species are grown for their leaves $[55,62]$. Women account for a majority of the production in Nigeria where it contributes to family income and nutritional requirements. Amaranth production account for a large proportion of the rural economy. Amaranth seeds, leaves, stem or whole plants are sold according to their weight at different prices across Nigeria. The tonnes of fresh and processed amaranths sold yearly in common open markets scattered all over Nigeria and the income generated from these activities contribute to both income and food security in Nigeria. However, it is rare to see amaranth in the popular megastores in Nigeria such as Shoprite. This is indicative of the low level of packaging and packaging support provided for the crops and their farmers. Ornamental amaranths make up part of the plants in some green spaces in major cities. Information on the international trade of amaranth in Nigeria is not available. The greater amount of leaves and seed correlate to marketability and greater economic values in amaranths species present in Nigeria. In the study by Mensah et al. [63], wherein they compared commonly consumed vegetables, their results suggests that amaranths are the most frequently used in parts of South-South Nigeria. In a similar study, the results from Arowosegbe et al. [64] showed that amaranth is second most important vegetable after Corchorus olitorius L. in Southwestern Nigeria.

\section{Nutritional/phytochemical composition of amaranths species in Nigeria}

Variability in phytochemical and proximate composition exist in the genus Amaranthus and depends on species and environmental condition (Tables $\mathbf{1}$ and 2). Generally, the leaves of amaranths have sufficient amounts of vitamin A forming carotenoids and can be used to fortify weaning food for children [13]. Amaranthus spp. are highly nutritious vegetables rich in protein, calcium, iron, vitamin A, C and $\mathrm{K}$ as well as in Riboflavin, niacin, vitamin and folate [54]. Amaranthus are healthprotective vegetables. Their availability and accessibility as a cheap source of vital nourishment and energy make them a right fit to fulfil or contribute significantly to food security component of sustainable development [82]. The crude fibre help in digestion, prevention of colon cancer, controlling cholesterol metabolism, and blood sugar regulation [83]. There is a correlation between nutrient compositions and dry matter and moisture content [48].

Their proximate and phytochemical composition can be influenced by the application of different soil amendment and additives such as fertilisers. In a study by Oyedeji et al. [34] they showed that NPK grown Amaranthus species had the highest protein while PM-grown vegetables had the highest ash content, crude fibre in A. cruentus grown with PM was significantly higher than NPK and the control whereas the NPK treatment of $A$. hybridus and $A$. deflexus had the highest crude 


\begin{tabular}{|c|c|c|c|c|c|c|c|c|c|}
\hline \multirow[t]{2}{*}{ Amaranthus spp. } & \multicolumn{9}{|c|}{ Proximate composition (\%) } \\
\hline & $\mathrm{CHO}$ & MC & Ash & Fat & Protein & $\mathrm{CF}$ & $\mathrm{CV}^{*}$ & DMC & Lipid \\
\hline A. blitum & 4.1 & 85.0 & 13.8 & 0.7 & 17.3 & 8.4 & 92.0 & $9-22$ & - \\
\hline A. caudatus ${ }^{+}$ & - & 74.8 & 64 & 10 & 14 & 8 & 200.4 & 7.2 & 5.5 \\
\hline A. cruentus $^{+}$ & 9.8 & 63.8 & 7.2 & 1.6 & 8.1 & 6.4 & - & - & 4.7 \\
\hline A. deflexus & 10.8 & 63.9 & 7.0 & - & 8.37 & 5.5 & - & - & 4.8 \\
\hline A. dubius & - & 82.5 & 3.3 & 1.9 & 2.7 & 2.5 & 42 & - & - \\
\hline A. graecizans & - & 72.7 & 22.0 & & 28.5 & 8.5 & 42 & - & - \\
\hline A. hybridus & 7.9 & 47.7 & 8.63 & 3.25 & 15.2 & 16.2 & 268.92 & - & 4.4 \\
\hline A. hypochondriacus ${ }^{+}$ & - & 11.1 & $3.3-4.1$ & 2.6 & $13.9-17.3$ & 2.5 & - & - & $4.8-7.7$ \\
\hline A. retroflexus & 6.8 & 88.0 & 18.8 & $<1$ & 20.3 & 10.8 & - & 40.0 & - \\
\hline A. spinosus & 8.7 & 84 & 6.8 & 1.4 & 3.6 & 0.6 & 62 & - & - \\
\hline A. thunbergii & 34.7 & 3.94 & 24.6 & 6.1 & 17.2 & 13.5 & 278.4 & - & - \\
\hline A.tricolor & 5.2 & 92.7 & 0.6 & 0.1 & 0.6 & 0.9 & - & - & - \\
\hline A. viridis & 7.7 & 87.9 & 1.9 & 0.5 & 2.1 & 1.9 & 43.4 & - & 5.3 \\
\hline \multicolumn{10}{|c|}{$\begin{array}{l}=\text { Kcal/100 g. } \\
+=\text { Grains. } \\
\text { Source: Adapted from Pederson et al. [65]; Ullah et al. [66]; Unwin and Buss [67], Grubben [58], Oyelola et al. [68]; } \\
\text { Akubugwo et al. [69], Nehal et al. [48], Oyedeji et al. [34], Sharma et al. [70], Sheela et al. [71], Antara [49], } \\
\text { Muriuki [72], Getachew et al. [73], Walsh [36], Umar et al. [74]. }\end{array}$} \\
\hline
\end{tabular}

Table 1.

Comparative proximate chemical composition of common Amaranthus species found in Nigeria.

fibre content. NPK and PM favoured growth and yield of the Amaranthus species but influenced proximate composition differently. Amaranths planted in open spaces perform better in terms of morphological growth and yield in (number of leaves) than the controlled environment during a typical growing season [56]. In another related study, Dada et al. [57] showed that the use of compost significantly influence the growth, dry matter, fresh shoot yield and proximate composition of A. cruentus whereas the combination of arbuscular mycorrhiza fungi and compost had less or no influence on the same characteristics.

Amaranthus species also contain some antinutrients such as oxalates, tannin, phenolics and phytates that are known to interfere with digestion, absorption and assimilation of nutrients by forming insoluble complexes and these are often present in variable amounts in the different species. Consumption of large amounts (of $A$. retroflexus for instance) has been reported to affect kidneys of cattle causing perirenal oedema and toxic nephrosis [36].

\section{Utilisation and products from Amaranthus species in Nigeria}

Soil preservation, human and animal food and medicine, research, aesthetic (as ornamentals), bioremediation and industrial applications characterise the utilisation of amaranths in Nigeria. Amaranths are primarily considered vegetable and the leaves and stem are used in potherb, salads, burgers, and soup or stew. The cheap price of this vegetable makes it a preferred choice for most Nigerians. Moreover, in most parts of Nigeria, different amaranth species are used to supplement diverse cereals and legumes, which make up the bulk of daily food. The poor 


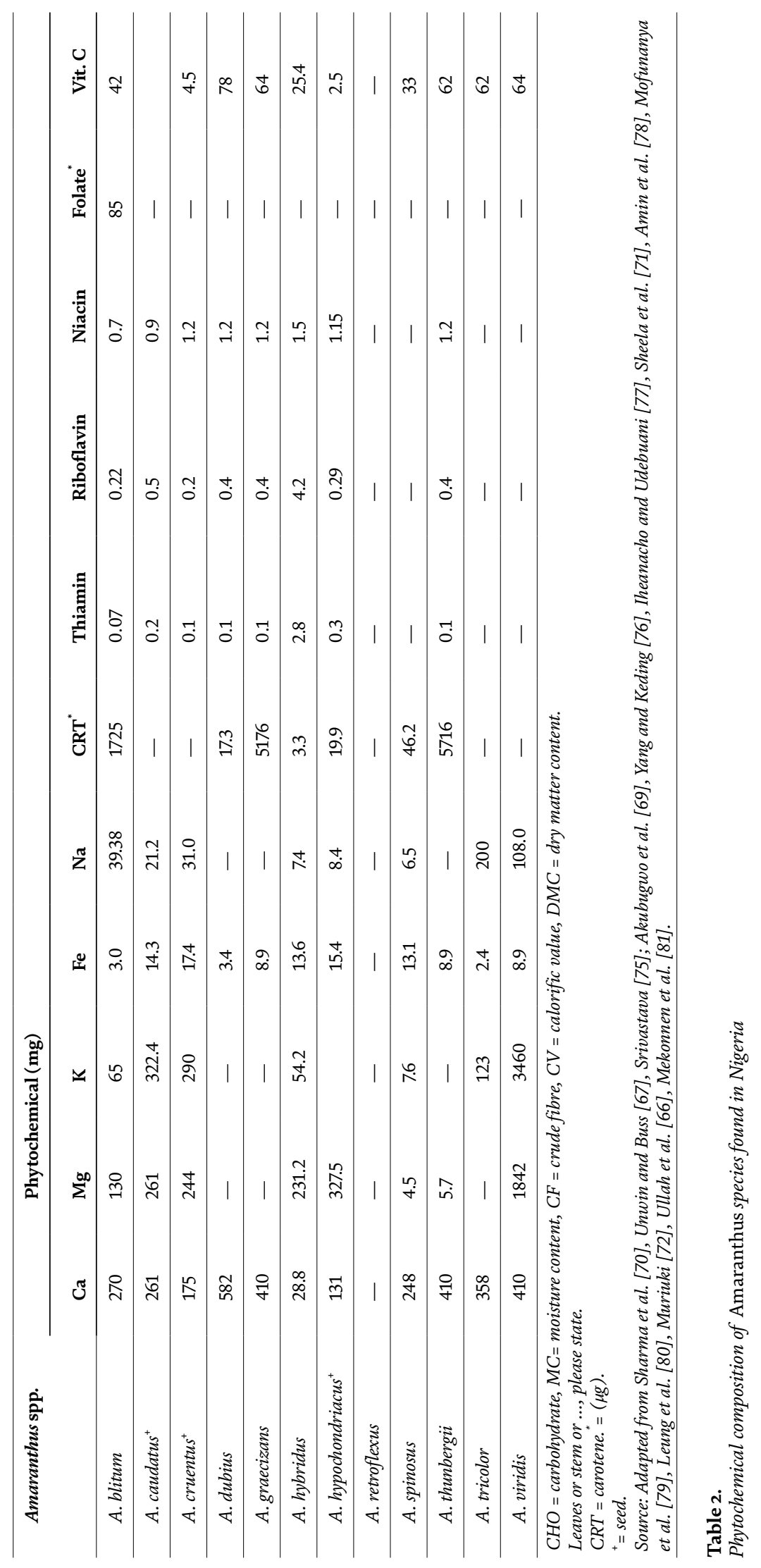


masses wconsider it equivalent to and a substitute to poultry eggs in nutritional composition and diets. The most common mode of utilising of Amaranthus species in Nigeria is to cook the leaves or grains and consumed as part of a Poaceae (cereal) or Fabaceae (legume)-rich diet. The leaves are also added in potpourri salads. According to Alegbejo [46], Nigerians value the leafy amaranths more than the grainy ones. Leaves are collected during the growth cycle when the nutrient is at the peak and mixed with condiments for the preparation of soup [50,84]. While the stems are also preferred fresh and succulent. This is why Akingbala et al. [85]; Akin-Idowu [86] opined that grain amaranths are underutilised in Nigeria despite their potential to contribute to food security and economic livelihood. Although they are cultivated primarily as a vegetable, their leaves, seeds and stems are used to add flavours to indigenous delicacies. They are also used as ornamentals to decorate parks, domestic and office complexes.

Grain amaranths are used as a substitute for corn in making ogi (a local porridge made usually with fermented cereal grains) because of the higher protein component, higher peak viscosity and lower setback value [85]. The grains of amaranth species can be mixed with wheat flour, salt, fat, yeast, sugar, and water and fermented, moulded, and baked to make quality bread [87]. The flours produced from the grains are used in many confectionery products. Seeds are used as ice cream toppings. The protein-rich grains of A. cruentus and A. hypochondriacus are milled for flour or popped and consumed as a substitute for popcorn [46]. A. viridis is used as an antiviral against human epidermoid carcinoma (HEP-2) cell line [88]. Washing of leaves with warm water is recommended before consuming fresh or cooking. The grains (seeds) are sometimes added into the soup as well or used as a breakfast snack or ground and used to thicken the soup. The most popular mode of using the seed is to blend it alone or mixed with cereal grains to make flour. The grains are also fed to poultry while the leaves, stem and inflorescence are fed to cattle and other livestock [89].

As a way of adding value to the leaves of amaranths, Agbede et al. [90] reported that quality leaf meals are produced from the vegetables through fractionation. Moreover, Tapia-Blacido et al. [91] reported that the presence of proteins and lipids in the flour films of amaranth leaf-flour has effects on the solubility, colour and opacity of the films but the overall film properties depends on the interactions formed by their polymers (starches and proteins) and by the lipid, on the distribution of these interactions within the film matrix and on the concentrations of each component in the film. Yellow, red and green dyes are obtained from different amaranth species and used to colour textile materials, beverages, medicines and food products. The leaves, stems and grains have unique flavours and are used to add flavours to food and confectionery products. Oil and pharmaceutical products are also extracted from the seeds. The oil contains high priced ingredient (squalene) that is otherwise obtained from shark liver used in traditional and contemporary medicine.

\section{Recommendations and conclusion}

The report of NRC [13] acknowledged that the crop has contributed significantly to food and income security especially in Nigeria and Africa regardless of a lack of formal support. Thus, the crop can reach admirable heights if production, storage, transport and other formal support is provided. There is a need for more research that will generate useful statistics on the amount of and area under cultivation, cost of amaranth products, demand and supply trends, and foreign exchange earnings. Nutritional studies need to also to be conducted to reflect the importance 
of some processed products obtained from amaranths. Extracts from Amaranthus species should be used in producing drugs that are a dietary supplement (nutraceuticals) as well as in the treatment of some disease conditions. Prior to consumption, amaranths should be washed with warm water. This is necessary as Akinnibosun and Adeola [92] found many microorganisms that are of public health concern on the leaves of $A$. hybridus. The groups contain a lot of underexploited plants with potential for medicinal application, food and income security. Many research gaps need to fill especially the phytochemical composition of $A$. retroflexus.

Weedy amaranths should be exploited to improve widely cultivated species through the application of biotechnology. This will introduce more resilience traits into the cultivars including but not restricted to disease resistance and faster maturation and adaptability to different conditions. For instance, $A$. hybridus can contribute to early maturity of grain amaranths [93]. The resulting GM crops should be extensively studies for their short and long term risks and benefits before introduction into the market [94]. Protection of the environment should be considered paramount in the control of weedy representatives of amaranths. Biological control should be adopted and integrated with shades as this can affect their perception of and absorption of light.

To maximise the benefits from Amaranth production, there is need to increase investment in their production, good pre and post-harvest management strategies, increase market assess, [4], improve seed availability and the provision of extension services of farmers. According to Schreinemachers et al. [4], market-oriented Amaranth farming will ensure that farmers maximise income generation while remaining resilience to external risks. It is also recommended hereof that grains of amaranths should continue to be combined with conventional ogi and bread cereals (wheat, maize, sorghum, and millet) to make a more nutritious product with higher protein content. They can also be mixed in the innovative cassava bread introduced by the previous administration in Nigeria with the same goal of higher nutrient content. There is a need to increase support for ethnobotanical practices related to amaranths as it can contribute to the conservation of vital knowledge about the germplasm and their conservation status [95].

It is important to iincrease collaboration with the World Vegetable Center, which is an international research organisation founded in 1971 with the mandate to promote vegetable production and consumption. Other related important organisations with similar mandates include the Asian Vegetable Research and Development Center (AVRDC). As a way to maximise Nigeria's interaction with these organisations, it is necessary that we establish a National vegetable research institute to be called the 'Nigerian Vegetable Center'. This will oversee research on vegetables, monitor their production, encourage consumption and trade-related activities such as galvanising the activities of already existing small and medium scale vegetablebased industries that are scattered all over the country. Moreover, it will be the representative voice for Nigeria vegetable interests and monitor activities such as the recently AVRDC funded onion storage facility in Sokoto state, Northwestern Nigeria. Moreover, this indigenous centre will contribute to understanding the diversity of vegetable and help prevent threats to their sustainable utilisation and conservation $[2,96,97]$. 


\section{Author details}

Matthew Chidozie Ogwu $\mathrm{u}^{1,2,3}$

1 School of Bioscience and Veterinary Medicine, University of Camerino, Camerino, Marche, Italy

2 Floristic Research Center of the Apennine, Gran Sasso and Monti della Laga National Park, San Colombo, Barisciano, L'Aquila, Italy

3 Department of Plant Biology and Biotechnology, Faculty of Life Sciences, University of Benin, Benin City, Edo State, Nigeria

*Address all correspondence to: matthew.ogwu@uniben.edu

\section{IntechOpen}

(C) 2020 The Author(s). Licensee IntechOpen. This chapter is distributed under the terms of the Creative Commons Attribution License (http://creativecommons.org/licenses/ by/3.0), which permits unrestricted use, distribution, and reproduction in any medium, provided the original work is properly cited. (cc) BY 


\section{References}

[1] Prohens J, Nuez F. Handbook of Plant Breeding. Vegetables II: Fabaceae, Liliaceae, Solanaceae and Umbelliferae. New York, United States: Springer Nature; 2007. 364p

[2] Ogwu MC, Osawaru MC, Aiwansoba RO, Iroh RN. Status and prospects of vegetables in Africa. In: Proceedings of NTBA/NSCB Joint Biodiversity Conference on MDGs to SDGs: Toward Sustainable Biodiversity Conservation in Nigeria held at University of Ilorin, Nigeria. 2016. pp. 47-57

[3] CDC (Center for Disease Control and Prevention USA). State Indicator Report on Fruits and Vegetable. Atlanta, GA: CDC; 2018. 18p

[4] Schreinemachers P, Simmons EB, Woperesi MCS. Tappin the economic and nutritional power of vegetables. Global Food Security. 2018;16:36-45

[5] Thompson FE, Willis GB, Thompson OM, Yaroch AL. The meaning of 'fruits' and 'vegetables'. Public Health Nutrition. 2011;14(7):1222-1228. DOI: 10.1017/S136898001000368X

[6] Welbaum GE. Chapter 1: Vegetable history, nomenclature, and classification. In: Wilbaum GE, editor. Vegetable Production and Practices. United Kingdom: CABI Press; 2015. 486p

[7] Busari AO, Idris-Adeniyi KM, Oyekale JO. Economic analysis of vegetable production by rural women in Iwo zone of Osun state, Nigeria. Greener Journal of Agricultural Sciences. 2012;3(1):006-011

[8] Slavin JL, Lloyd B. Health benefits of fruits and vegetables. Advances in Nutrition. 2012;3(4):506-516. DOI: 10.3945/an.112.002154

[9] Alberta Health Services. A Look at the Relationship between
Socio-Economic Status and Fruit and Vegetable Consumption in Alberta. Alberta Health Services, Diabetes, Obesity and Nutrition Strategic Clinic Network; Alberta, United Kingdom. 2014. 2p. Available from: https://www.albertahealthservices.ca/ Strategic\%20Clinical\%20Networks/ahsscn-don-socio-economic-fruit-veggiefacts.pdf

[10] Sinha NK, Hui YH, Ozgul Evranuz E, Siddiq M, Ahmed J. In: Sinha NK, editor. Handbook of Vegetables and Vegetable Processing. Blackwell Publishing Ltd.; 2011. 426p

[11] Ogwu MC. Chapter

11-understanding the composition of food waste: An “-Omics” approach to food waste management. In: Gunjal AP, Waghmode MS, Patil NN, Bhatt P, editors. Global Initiatives for Waste Reduction and Cutting Food Loss. Pennsylvania, USA: IGI Global; 2019. pp. 212-236. DOI: $10.4018 / 978-1-5225-$ 7706-5.ch011

[12] Ali M, Tsou SCS. Combating micronutrient deficiencies through vegetables-a neglected food frontier in Asia. Food Policy. 1997;22(1):17-38

[13] NRC (National Research Council). Lost Crops of Africa: Volume II: Vegetables. Washington, DC: The National Academies Press; 2006. pp. 35-51

[14] NRC (National Research Council). Amaranth: Modern Prospects for an Ancient Crop. Report of an Ad Hoc Panel of the Advisory Committee on Technology Innovation Board on Science and Technology for International Development Office of International Affairs National Research Council. Washington, DC: National Academy Press; 1989. 96p 
Value of Amaranthus [L.] Species in Nigeria

DOI: http://dx.doi.org/10.5772/intechopen.86990

[15] De Candolle A. Appleton Origin of cultivated plants. In: The International Scientific Series: New York, United States; 1984. 532p

[16] Vavilov NI. Centers of origin of cultivated plants. Bulletin of Applied Botany, of Genetics and Plant Breeding. 1927;16:1-248

[17] Saunders RM, Becker R. Amaranthus: A potential food and feed resource. In: Pomeranz Y, editor. Advances in Cereal Science and Technology. St. Paul: American Association of Cereal Chemists; 1984. pp. 357-397

[18] Stone LA, Lorenz K. The starch of Amaranthus-physicochemical properties and functional characteristics. Starch/Stärke. 1984;36:232-237

[19] Sauer JD. The grain amaranths and their relatives: A revised taxonomic and geographic survey. Annals of Missouri Botanical Garden. 1967;54:103-137

[20] Osawaru ME, Ogwu MC, Ahana CM. Current status of plant diversity and conservation in Nigeria. Nigerian Journal of Life Sciences. 2013;3(1):168-178

[21] PFAF (plant for a future) Amaranthus blitum L. 2009. Available from: https://pfaf.org/user/Plant.aspx?L atinName $=$ Amaranthus + blitum

[22] NC State Extension. Amaranthus caudatus. 2019. Available from: https://plants.ces.ncsu.edu/plants/all/ amaranthus-caudatus/

[23] Spice Garden. Amaranthus cruentus. 2019. Available from: http://www. spicegarden.eu/Red-Amaranth-SeedsAmaranthus-cruentus

[24] Botanica y Jardines. Amaranthus dubius. 2012 Available from: http:// www.botanicayjardines.com/ amaranthus-dubius/
[25] CalPhotos. Amaranthus deflexus. 2006. Available from: https://calphotos. berkeley.edu/cgi/img_query?enlarge $=$ $0000+0000+0706+0654$

[26] Maundu PM, Grubben GJH.

Amaranthus graecizans L. In:

Grubben GJH, Denton OA, editors. PROTA (Plant Resources of Tropical Africa/Ressources végétales de l'Afrique tropicale). Netherlands: Wageningen; 2004. Available from http://www. prota4u.org/search.asp

[27] USDA (United States Department of Agriculture). Amaranthus hybridus L. slim amaranth. 1998. Available from: https://plants.usda.gov/core/ profile?symbol=AMHY

[28] Jakubec K. Flowering Plant Amaranthus hypochondriacus from the Botanical Garden of Charles University, Prague, Czech Republic. 2011. Available from: https://en.wikipedia.org/wiki/ Amaranthus_hypochondriacus\#/media/ File:Amaranthus_hypochondriacus_ Prague_2011_1.jpg

[29] UMassAmherst Amaranthus retroflexus. 2019. Available from: https:// extension.umass.edu/landscape/weeds/ amaranthus-retroflexus

[30] African Plants: A Photo Guide. Amaranthus spinosus. 2019. Available from: http://www.africanplants. senckenberg.de/root/index. php?page_id $=78 \& \mathrm{id}=92$

[31] Hyde MA, Wursten BT, Ballings P, Coates Palgrave M. Flora of Mozambique: Species Information: Individual Images: Amaranthus thunbergii. 2019. Available from: https://www.mozambiqueflora. com/speciesdata/image-display. php?species_id=122220\&image_id=12

[32] Joydeep. Amaranthus viridis flower. Photographed at Burdwan, West Bengal, India. 2014. Available from: https://en.wikipedia.org/ 
wiki/Amaranthus_viridis\#/media/ File:Amaranthus_viridis_25042014_1. jpg

[33] Paredes-Lopez O, HernandezLopez D. Food properties of Amaranth seeds and methods for starch isolation and characterization. In: Linskens H-F, Jackson JF, editors. Seed Analysis. Berlin: Springer-Verlag; 1992. 376p

[34] Oyedeji S, Animasaun DA, Bello AA, Agboola OO. Effect of NPK and poultry manure on growth, yield, and proximate composition of three amaranths. Journal of Botany. 2014;2014:828750. DOI: $10.1155 / 2014 / 828750$

[35] FNA (Flora of North America). Flora of North America. Volume 4. New York, Oxford: FNA; 2003. Available from: http://www. efloras.org/florataxon.aspx? flora_id=1\&taxon_id=242414702

[36] Walsh RA. Amaranthus retroflexus. In: Fire Effects Information System. U.S. Department of Agriculture, Forest Service, Rocky Mountain Research Station, Fire Sciences Laboratory (Producer). Fort Collins, Colorado, United States; 1993. Available from: https://www.fs.fed.us/database/feis/ plants/forb/amaret/all.html

[37] Schonbeck M. Spiny Amaranth (Amaranthus spinosus). 2012.

Available from: https://articles. extension.org/pages/65210/ spiny-amaranth-amaranthus-spinosus

[38] Kirby G. Wild Flowers of Southeast Botswana. Cape Town, South Africa: Struik Nature; 2013. 344p

[39] Shukla S, Bhargava A, Chatterjee A, Srivastava J, Singh N, Singh SP. Mineral profile and variability in vegetable amaranth (Amaranthus tricolor). Plant Foods for Human Nutrition. 2006;61(1):23-28
[40] Tony-Odigie AE, Adekoya KO, Makinde SCO, Oboh BO, Ogunkanmi LA, Fowora MA. Assessment of genetic interspecies relationship among five selected Amaranthus species using phenotypic and RAPD markers. International Journal of Botany. 2012;8(3):145-152

[41] Osawaru ME, Ogwu MC.

Ethnobotany and germplasm collection of two genera of cocoyam (Colocasia [Schott] and Xanthosoma [Schott], Araceae) in Edo state Nigeria. Science, Technology and Arts Research Journal. 2014;3(3):23-28

[42] Ogwu MC, Osawaru ME, Aiwansoba RO, Iroh RN. Ethnobotany and collection of west African okra [Abelmoschus caillei (a. Chev.) Stevels] germplasm in some communities in Edo and Delta states, southern Nigeria. Borneo Journal of Resource Science and Technology. 2016;6(1):25-36

[43] Ogwu MC, Osawaru ME, Obahiagbon GE. Ethnobotanical survey of medicinal plants used for traditional reproductive care by Usen people of Edo state, Nigeria. Malaya Journal of Biosciences. 2017;4(1):17-29

[44] Ogwu MC, Chime AO, Oseh OM. Ethnobotanical survey of tomato in some cultivated regions in southern Nigeria. The Maldives National Journal of Research. 2018;6(1):19-29

[45] Burkill HM. The Useful Plants of West Tropical Africa: Volume 1. Kew, United Kingdom; Royal Botanic Gardens, Kew. 1985. 154p

[46] Alegbejo JO. Nutritional value and utilization of Amaranthus (Amaranthus spp.)-A review. Bajero Journal of Pure and Applied Sciences. 2013;6(1):136-143

[47] Mowobi GG, Abubakar S, Osuji C, Etim VN, Nweke O, Egya JJ. Ethnobotanical survey of medicinal 
plants used for the treatment of skin disease in Keffi, Nigeria. American Journal of Phytomedicine and Clinical Therapeutics. 2016;4(2):073-090

[48] Nehal N, Mann S, Gupta RK. Nutritional and phytochemical evaluation of $A$. lividus L. syn Amaranthus blitum subsp. oleraceus (L.) Costea leaves. Indian Journal of Traditional Knowledge. 2016;15(4):669-674

[49] Antara C. Evaluation of physicochemical and phytochemical parameters of Amaranthus spinosus leaves. International Research Journal of Pharmacy. 2012;3(10):210-211

[50] Oke OL. Amaranth in Nigeria. In: Proceedings of the Second Amaranth Conference. Emmaus, PA: Rodale Press; 1983. pp. 22-30

[51] Soladoye MO, Chukwuma EC, Sulaiman OM, Feyisola RT. Ethnobotanical survey of plants used in the traditional treatment of female infertility in southwestern Nigeria. Ethnobotanical Research and Application. 2014;12:081-090

[52] Assad R, Reshi ZA, Jan S, Rashid, I. Biology of Amaranths. The botanical review. 2017;83:382-436.

DOI: 10.1007/s12229-017-9194-1

[53] Achigan-Dako EG, Sogbohossou OED, Maundu P. Current knowledge on Amaranthus spp.: Research avenues for improved nutritional value and yield in leafy amaranths in sub-Saharan Africa. Euphytica, 2014;197:303-317. DOI: 10.1007/ s10681-014-1081-9

[54] Ebert AW, Wu T-H, Wang

S-T. Vegetable amaranth (Amaranthus L.). In: International Cooperators Guide. AVRDC Publication. Shanhua, Taiwan; 2011
[55] Alonge SO, Alonge FO, Bako SP, Olarewaju JD, Adeniji OB. Effects of rates and split application of compound NPK fertilizer on the growth and yield of three Amaranthus species in Nigeria Guinea savanna. Asian Journal of Plant Sciences. 2007;6:906-912

[56] Ufoegbune G, Adekunle AA, Adebiyi GA, Bello NJ, Eruola KO. Performance of Amaranthus species under two different environmental conditions in derived savannah agroecology, southwestern Nigeria. African Journal of Agriculture, Technology and Environment. 2015;4(2):33-45

[57] Dada OA, Imade F, Anifowose EM. Growth and proximate composition of Amaranthus cruentus L. on poor soil amended with compost and arbuscular mycorrhiza fungi. International Journal of Recycling of Organic Waste in Agriculture. 2017;6:195-202

[58] Grubben GJH. Amaranthus thunbergii Moq. In: Grubben GJH, Denton OA, editors. PROTA (Plant Resources of Tropical Africa/Ressources végétales de l'Afrique Tropicale). Netherlands: Wageningen; 2004. Available from: http://www.prota4u. org/search.asp

[59] Tropical Plants Database. Amaranthus tricolor. 2019.

Available from: http://tropical. theferns.info/viewtropical. php?id=Amaranthus+tricolor

[60] Ogunkunle CO, Ziyath AM, Adewumi FE, Fatoba PO.

Bioaccumulation and associated dietary risks of $\mathrm{Pb}, \mathrm{Cd}$, and $\mathrm{Zn}$ in amaranth (Amaranthus cruetus) and jute mallow (Corchorus olitorius) grown on soil irrigated using polluted water from Asa river, Nigeria. Environmental Monitoring and Assessment. 2015;187(5):281. DOI: 10.1007/ s10661-015-4441-6 
[61] Vwioko DE, Okoekhian I, Ogwu MC. Stress analysis of

Amaranthus hybridus L. and Lycopersicon esculentum mill. Exposed to Sulphur and nitrogen dioxide. Pertanika Journal of Tropical Agricultural Science. 2018;41(3):1169-1191

[62] Musa M, Singh A, Lawal AA. Influence of priming duration on the performance of Amaranths (Amaranthus cruentus L.) in Sokoto semiarid zone of Nigeria. International Journal of Agronomy. 2014;2014:475953

[63] MensahJK, OkoliRI, Ohaju-ObodoJO, Eifediyi K. Phytochemical, nutritional and medical properties of some leafy vegetables consumed by Edo people of Nigeria. African Journal of Biotechnology. 2008;7(14):2304-2309

[64] Arowosegbe S, Olanipekun MK, Adeloye IA. Ethnobotanical survey of indigenous leafy vegetable consumed in Ekiti state, Nigeria. European Journal of Biology and Medical Science Research. 2018;6(1):7-14

[65] Pederson B, Kalinowski LS, Eggum BO. The nutritive value of amaranth grain (Amaranthus caudatus). Plant Food and Human Nutrition. 1989;36(4):309-324

[66] Ullah I, Gul S, Rehman HU, Ahmad N, Ullah I, Din A-U, et al. Analysis of nutrients and minerals of some wild edible plants. International Journal of Fauna and Biological Studies. 2017;4(6):35-39

[67] Holland ID, Unwin, Buss DH. Vegetables, herbs and spices. The fifth supplement to McCance and Widdowson's The Composition of Foods. 4th Edition. Royal Society of Chemistry. Cambridge, United Kingdom. 1991. 163 pp

[68] Oyelola O, Banjoko I, Ajioshin I. Nutritional content of common
Amaranthus hybridus vegetable (Efo Tete) in Nigeria. The FASEB Journal. 2014;28(1):828

[69] Akubugwo IE, Obasi NA, Chinyere GC, Ugbogu AE. Nutritional a d chemical value of Amaranthus hybridus L. leaves from Afikpo, Nigeria. African Journal of Biotechnology. 2007;6(24): 2833-2839

[70] Sharma N, Gupta PC, Rao CV. Nutrient content, mineral content and antioxidant activity of Amaranthus virids and Moringa oleifera leaves.

Research Journal of Medicinal Plants. 2012;6(3):253-259

[71] Sheela K, Nath KG, Vijayalakshmi D, Yankanchi GM, Patil RB. Proximate composition of underutilized green leafy vegetables in southern Karnataka. Journal of Human Ecology. 2004;15(3):227-229

[72] Muriuki EN. Nutritional diversity of leafy amaranth (Amaranthus) species grown in Kenya [MSc thesis]. Kenya: Jomo Kenyatta University of Agriculture and Technology; 2015. 95p

[73] Getachew AG, Asfaw Z, Singh Z, Woldu Z, Baidu-Forson JJ, Bhattacharya S. Dietary values of wild and semi-wild edible plants in southern Ethiopia. African Journal of Food Agriculture, Nutrition and Development. 2013;13(2):7485-7503

[74] Umar KJ, Hassan LG, Dangoggo SM, Maigandi SA, Sani NA. Nutritional and anti-nutritional profile of spiny amaranth (Amaranthus viridis Linn). Studia Universitatis "Vasile Goldiş”. Seria Ştiințele Vieții. 2011;21(4):727-737

[75] Srivastava R. Nutritional quality of some cultivated and wild species of Amaranthus L. International Journal of Pharmaceutical Sciences and Research. 2011;17:3152-3156 
[76] Yang R, Keding GB. Nutritional contributions of important African indigenous vegetables. In: Shackleton CM, Pasquini MW, Drescher A, editors. African Indigenous Vegetables in Urban Agriculture. London, UK: Earthscan; 2009. pp. 105-143

[77] Iheanacho KME, Udebuani AC. Nutritional composition of some leafy vegetables consumed in Imo state, Nigeria. Journal of Applied Science and Environmental Management. 2009;13(3):35-38

[78] Amin MZ, Karim S, Sawraz AM, Satter A. A comparative nutritional analysis of red amaranth (Amaranthus tricolor L.) on refrigerating and nonrefrigerating condition. International Journal of Green and Herbal Chemistry. 2015;4(3):243-245

[79] Mofunanya AAJ, Ebigwai JK, Bello OS, Egbe AO. Comparative study of the effects of organic and inorganic fertilizer on nutritional composition of Amaranthus spinosus L. AmericanEurasian Journal of Agriculture and Environmental Science. 2014;14(9):824-830

[80] Leung WTW, Busson F, Jardin C. Food composition table for use in Africa. Rome, Italy: FAO; 1968. 306 pp

[81] Mekonnen G, Woldesenbet M, Teshale T, Biru T. Amaranthus caudatus production and nutrition content for food security and healthy living in Menit Shasha, Menit Goldya and Maji districts of bench Maji zone, South Western Ethiopia. Nutrition and Food Science. 2018;7(3):001-007

[82] Ogwu MC. Towards sustainable development in Africa: The challenge of urbanization and climate change adaptation. In: Cobbinah PB, Addaney M, editors. The Geography of Climate Change Adaptation in
Urban Africa. Switzerland: Springer Nature; 2019. pp. 29-55. DOI: 10.1007/978-3-030-04873-0_2

[83] US Institute of Medicine. Dietary Reference Intakes for Energy, Carbohydrate, Fibre, Fat, Fatty Acids, Cholesterol, Amino Acids (Macronutrients). Washington DC, USA: The National Academy Press; 2005. pp. 380-382

[84] Rastogi A, Shukla S. Amaranth: A new millennium crop of nutraceutical values. Critical Reviews in Food Science and Nutrition. 2013;53(2):109-125

[85] Akingbala JO, Adeyemi IA, Sangodoyin SO, Oke OL. Evaluation of amaranth grains for Ogi manufacture. Plant Food for Human Nutrition. 1994;46(1):19-26

[86] Akin-Idowu PE, Gbadegesin MA, Orkpeh U, Ibitoye DO, Odunola OA. Characterization of grain amaranth (Amaranthus spp.) germplasm in south West Nigeria using morphology, nutritional, and random amplified polymorphic DNA (RAPD) analysis. Resource. 2016;5:6. DOI: 10.3390/ resources5010006

[87] Ayo JA. The effect of amaranth grain flour on the quality of bread. International Journal of Food Properties. 2001;4(2):341-351. DOI: 10.1081/JFP-100105198

[88] Obi RK, Iroagba II, Ojiako OA. Virucidal potential of some edible Nigerian vegetables. African Journal of Biotechnology. 2006;5(19):1785-1788

[89] Amicarelli V, Camaggio G.

Amaranthus: A crop to discover. Forus Ware International. 2012;2:4-11

[90] Agbede JO, Adeyeye SA, Adegbenro M. Nutritional, functional property and bioactive components of the leaf products from 
edible vegetables. Revista Científica UDO Agrícola. 2012;12(3):741-748

[91] Tapia-Blacido D, Mauri AN, Menegalli FC, Sobral PJ, Anon MC. Contribution of the starch-protein, and lipid fractions o the physical, thermal, and structural properties of amaranth (Amaranthus caudatus) flour films. Journal of Food Science. 2007;72(5):293-300

[92] Akinnibosun FI, Adeola MO. Quality assessment and proximate analysis of Amaranthus hybridus, Celosia argentea and Talinum triangulare obtained from open markets in Benin City, Nigeria. Journal of Applied Science and Environmental Management. 2015;19(4):727-734

[93] Oboh B. Multivariate analysis of the diversity among some Nigerian accessions of Amaranthus hybridus. International Journal of Plant Breeding and Genetics. 2007;1:89-94

[94] Ogwu MC. Chapter 8-lifelong consumption of plant-based GM foods: Is it safe? In: Papadopoulou P, Misseyanni A, Marouli C, editors. Environmental Exposures and Human Health Challenges. Pennsylvania, USA: IGI Global; 2019. pp. 158-176. DOI: 10.4018/978-1-5225-7635-8.ch008

[95] Chime AO, Aiwansoba RO, Ogwu MC, Sunyani. Pathological status of plant germplasm and sustainable crop production and conservation. In: ICCSDA 2017 Special Issue. Ghana; Agriculture, Natural Resources and Renewable Energy. Vol. 1. Sunyani, Ghana: University of Energy and Natural Resources; 2018. pp. 17-21

[96] Ogwu MC, Osawaru ME, Ahana CM. Challenges in conserving and utilizing plant genetic resources (PGR). International Journal of Genetics and Molecular Biology. 2014;6(2):16-22
[97] Osawaru ME, Ogwu MC.

Conservation and utilization of plant genetic resources. In: Omokhafe K, Odewale J, editors. Proceedings of 38th Annual Conference of the Genetics Society of Nigeria. Nigeria: Empress Prints Nigeria Ltd; 2014. pp. 105-119 


\title{
Amaranth: An Ancient and High-Quality Wholesome Crop
}

\author{
Dinesh Adhikary, Upama Khatri-Chhetri and Jan Slaski
}

\begin{abstract}
Amaranth was a staple of the Aztec diet and is described as a "superfood" in part because of its high protein content and well-balanced amino acid profile. In terms of nutrient content, amaranth surpasses many staple crops such as rice, corn, and wheat. Additionally, lysine content is twice as much than in rice and thrice as much than in corn. Along with desirable agronomic traits, this crop has been hugely applauded for its gluten-free nature. Not only can it benefit vegan and gluten allergy personals, but it also has the potential to supply high-quality proteins and at the same time provides antimicrobial activities in the packaged food items. Despite all of these properties, this crop is still not in the mainstream cultivation practices in North America and in many parts of the world. As the planet is expecting massive increase in human population and global climate change, we firmly believe that this widely distributed, ancient, protein-rich pseudo-cereal has a potential to augment our food system. In this book chapter, we aim to report the nutritional properties of grain amaranth.
\end{abstract}

Keywords: amaranth, lysine, complete protein, gluten-free, ancient crop

\section{Introduction}

\subsection{Amaranthus sp. taxonomy and distribution}

Amaranthus L. is a eudicot genus in the Amaranthaceae family of the order Caryophyllales and is commonly known as the pigweeds or amaranths. The genus comprises about 75 species, which are generally annuals, and are distributed throughout the world's temperate and tropical regions [1, 2]. The genus Amaranthus is further divided into three subgenera, Acnida, Albersia, and Amaranthus [3], with Acnida being dioecious and subgenera Albersia and Amaranthus being monoecious but with distinctive floral morphology. The three main domesticated species of Amaranthus (Amaranthus caudatus L., A. cruentus L., and A. hypochondriacus L.) originated in the Americas and are primarily cultivated for grain, as potherbs and ornamentals $[2,4]$.

Amaranth is an ancient crop in which scientific and commercial interest has recently been renewed. The grain amaranths (A. hypochondriacus, A. caudatus, A. cruentus) have many favorable agronomic properties and are highly adaptable to various ecological zones, with better resistance to biotic and abiotic stresses than many conventional other food crops [2]. These species also have advantages of being protein-rich $\mathrm{C}_{4}$ pseudo-cereals that can be adapted to cultivation in a wide range of environments, with good tolerance of drought and salinity [2, 5]. Amaranths also exhibit superior water use efficiency compared to many other $\mathrm{C}_{3}$ and $\mathrm{C}_{4}$ crops [6]. 


\subsection{Amaranth use in the ancient times}

The grain amaranth was an important crop for the Aztecs and the Incas [1, 2]. In the pre-Columbian period, it was one of the major crops like beans and corn in the New World and carried religious importance [1]. During the various dates of the religious calendar, Aztec people ground amaranth seeds mixed with honey or human blood and make different shapes of animals, birds, mountains, and gods, and they were eaten during the ceremonies $[1,2]$.

Prior to the conquest by Spaniards, Mexicans had a culture where a ceremonial paste called Zoale was prepared from amaranth grains and was fed to the slaves before they were sacrificed to the gods $[1,7]$. From the Christian viewpoint, the use of grain amaranth was the very symbol of heathen idolatry [1], and therefore Spaniards discouraged the cultivation of Amaranthus [1,7]. Although the cultivation was highly suppressed by the Spanish conquistadors, small patches of $A$. hypochondriacus were still grown inside maize fields [1, 2].

Along with the widespread use in food products, grain amaranths also gained religious significance in India and Nepal. In Uttar Pradesh, India, the crop amaranth is recognized as Ramdana (seed given by Lord Ram) [7]. In the states of Madhya Pradesh and Gujarat, India, amaranth is recognized as Rajgira (Rajgira, a seed given by King, an incarnation of Lord Vishnu). In Hindu culture, popped amaranth grain is soaked in milk and is one of the food items permitted to be eaten during religious festivals after a long fasting [2, 7]. In different parts of Nepal, India, and Pakistan, popped amaranth seed is used to make laddoos and confections like alegria in Mexico. Laddoos carries an important religious significance. It is considered a pure food and can be offered to Hindu gods. Around the Nilgiri Hills in India, Badagas peoples have a ritual that they offer a basket of puffed amaranths on Badagas funeral pyre $[7,8]$. Looking at those cultural instances, grain amaranths may have been migrated from the Americas to the Old World only about 500 years ago; but it is quite astonishing to get strong evidences on the connection of amaranth grain to Hindu culture in the Old World.

\section{Nutritional facts of amaranths}

\subsection{Amaranth proteins}

Based on the solubility and extractability, there are four major seed storage proteins in plants: albumins, globulins, prolamins, and glutelins. In pseudo-cereals, including amaranth, the major seed storage proteins are composed of albumin, globulin, and glutelin [9-13]. However, there are some reports showing traces of prolamins in some of the amaranth species $[10,12]$. Storage proteins accumulate in developing seeds and store nitrogen, carbon, and sulfur [14]. These proteins are hydrolyzed and mobilized during seed germination and early seedling growth $[14,15]$. They do not carry any enzymatic functions and are found only in seeds. However, some storage proteins may also be involved in defense or metabolism. These proteins are synthesized in the rough endoplasmic reticulum. As seeds mature, they are collected in the protein bodies that are derived from vacuole [15]. They may also act as a sink for excess nitrogen.

Chief distinction between the major proteins is outlined as follows: albumin storage proteins are water soluble with low molecular weight $10-18 \mathrm{kDa}$ and low isoelectric point between $\mathrm{pH} 4.0$ and 5.0 [16]. Based on the sedimentation coefficients $\left(\mathrm{S}_{20 \mathrm{w}}\right)$, albumin has the coefficient of approximately $2 \mathrm{~S}$; therefore it is defined as $2 \mathrm{~S}$ albumin [17]. However, in the case of pseudo-cereals, the sedimentation 
coefficients of $1.7 \mathrm{~S}$ comprised of polypeptides with Mr. ranging from 4000 to 20,000 , and they are high in sulfur-containing amino acids, including cysteine and methionine [17]. Majority of albumins consists of two polypeptide chains linked by four disulfide bonds [18]. They are found in dicot plants and account for $20-60 \%$ of the total proteins in seed [16]. Globulin storage proteins are soluble in salt with their molecular weights in the range of $150-190 \mathrm{kDa}$ [16]. They have an isoelectric point of $\mathrm{pH}$ 5-10 [19]. Based on the sedimentation coefficients, $\left(\mathrm{S}_{20 \mathrm{w}}\right)$, globulin has the coefficients ranging from $7 \mathrm{~S}$ to $12 \mathrm{~S}$ [16]. They lack cysteine residues and lack disulfide bonds [16]. Glutelin storage proteins are soluble in borate buffer but poorly soluble in water. They have molecular weights in the range of $45-150 \mathrm{kDa}$ and an isoelectric point range between the $\mathrm{pH}$ range of 4.8 and 8.7 and are highly hydrophobic in nature [16]. They are high in proline and glutamine content [16]. One of the distinctive signal peptides that is distinguished from other storage proteins is the 37 amino acid sequence at the $\mathrm{NH}_{2}$ terminus that is followed by 269 amino acid acidic subunit $(\mathrm{Mr}=32,489)$ and a 193 amino acid basic unit $(\mathrm{Mr}=19,587)$ [20].

\subsection{Lysine content}

Amaranth grain and leaves are popular for their nutritional value. Protein content is about $15 \%$ in grains [21], and it has a well-balanced amino acid composition with high lysine content [22]. Lysine is the limiting amino acid in most of the cereal crops including wheat, sorghum, and rice, but it is abundant in amaranth; only the first limiting amino acid in amaranth is leucine [21], and it is also abundant in most of our staple food sources. Therefore, amaranth is considered as a complete protein supplier when it is consumed with another cereal.

\subsection{Seed properties and nutrient content}

Grain amaranth plant produces millions of seeds that are small $(\approx 1 \mathrm{~mm})$ in diameter and has not been analyzed for detailed morphological features [23, 24]. The color of the seeds is highly variable from white, gold, brown, and pink to black [24]. Coons [25] reported that black color is dominant over white and a single gene controls the inheritance. It is possible that the seed coat colors, perisperm type, and seed shape in Amaranthus species are controlled by different gene loci. Seed shape changes based on angle of view; in lateral view seeds appear lenticular in shape, and in front view seeds appear circular or obovate [23]. Adhikary [24] reported white-vitreous and white-opaque type of seeds. Although seed shape and size may not have a significant impact in the nutrient content of a seed, some pigmented seeds have been reported to contain different amounts of nutrient components. For instance, [21] reported that pale-colored seeds of $A$. caudatus contain about $14 \%$ of protein, $10 \%$ of fat, $64 \%$ of starch, and $8 \%$ of dietary fiber, while black-pigmented seeds were reported to contain $16 \%$ of dietary fiber, with lysine concentration ranged between 5.2 and $6.0 \mathrm{~g} / 16 \mathrm{~g} \mathrm{~N}$ in the grains [21]. Moreover, protein digestibility was found to be higher in pale seeds than in the black seeds [21].

Starch is formed by two glucan polymers, amylose and amylopectin [26], and is stored in the perisperm of amaranth seed [27]. Like the grasses, amaranth starch can be classified as either glutinous (waxy) or non-glutinous (starchy) [27]. Nonglutinous (starchy) seeds contain both amylose and amylopectin, and glutinous (waxy) seeds lack amylose $[24,26]$. Both perisperm forms are found in all three species of the grain Amaranthus [26]. Amaranth seeds contain $65-75 \%$ of starch [28], and the digestibility of cooked amaranth seeds resulted in a similar response to white bread; however, flaked and roasted seeds responded with a slightly increased glycemic response [29, 29]. 


\subsection{Squalene content}

Squalene is a unique triterpene compound that has a biological and pharmacological importance. Although squalene is an intermediate product in the cholesterol biosynthesis process [30], earlier work has predicted that daily consumption can decrease cholesterol levels [31]. It can inhibit chemically induced breast and colon cancer [32]. There are also evidences of a lower frequency of heart diseases in the Mediterranean region [33], as people in this region consume more olive oil, which is rich in squalene [34]; thus it is believed that squalene consumption in the diet has a positive impact on human health. It originates partly from cholesterol synthesis process and partly from dietary sources such as plant oils or shark liver. Among the different types of plant oils, oil extracted from olive and amaranth has a higher concentration of squalene $[34,35]$. Especially, grain amaranths have been suggested as an alternative natural source of squalene. The chemical content in five different accessions of $A$. cruentus was reported in the range of 2.26-5.67\% [36]. Furthermore, in other domesticated species, [37] reported 3.6\% in A. hypochondriacus and $6.1 \%$ in $A$. tricolor.

\subsection{Gluten-free grain}

Amaranthus is a gluten-free grain [38], and hence it is a suitable diet for a person with celiac disease (CD) [39, 40]. CD is an autoimmune condition or inflammatory disease, which affects the small intestine triggered by the gluten protein [41, 42] and can lead to weight loss, fatigue, malabsorption, abdominal pain, vomiting, and diarrhea [43]. The main sources of gluten protein are wheat, barley, and rye [42]. CD patients must follow a strict gluten-free diet, and this can potentially lead to nutrient deficiency [43]. Generally, gluten-free products are made with refined flours and starch and require specific packaging material and frequent use of chemical preservatives $[44,45]$. This makes a challenge for both producer and consumer. One of the biggest challenges for food technologist is to enrich the nutritional value of gluten-free products with balanced dietary fibers and proteins $[44,46]$. Hence, amaranths can be an alternative to address the challenge. In fact, amaranth has become one of the greatest supplements in gluten-free food commodities to enhance nutritional values [47]. Amaranth contains similar macronutrients as wheat and 2-3 times higher than other gluten free crops [42]. Seed protein of amaranth is greater than cereals and legumes [22]. Besides, amaranth has higher lysine and starch than in other cereals [40]. Monosaccharide composition of dietary fiber present in amaranth is well known [48, 24], and amaranth could serve as a significant source of dietary fiber [48]. Moreover, amaranth has higher fiber and mineral content than other gluten-free grains [21]. In today's context, amaranth is one of the few gluten-free pseudo-cereals that has been used in a wide variety of gluten-free food commodities. Amaranth is usually combined with other gluten-free cereals such as rice, corn, and cassava in a variety of food products. For example, blending of amaranth with other flours such as cassava [46] and rice [47] in pasta formulation and rice and maize in bakery items $[49,42]$ has been introduced to enhance the nutritional value of the pasta and bakery items [46]. Because of its higher nutritional profile, genetic diversity, and high adaptability, amaranth can be considered as an excellent supplement to produce gluten-free food products.

One of the most common and costly problems affecting bakery products is fungal contamination. Rizzello et al. [45] reported that the use of amaranth in bakery products can enhance antifungal activity in bread. Amaranth seeds contain some antifungal peptides, which can show a defensive response toward pathogenic fungi [50]. It is noteworthy to mention that amaranth is rich in betalain pigment, 
which has also been shown to exhibit antimicrobial activities. Thus, betalain is a high demand in the food coloring industry. These pigments with a strong hue not only color the food products but also provide strong antimicrobial response. Thus, amaranth can be an excellent natural additive in the food industry.

\subsection{Antioxidant properties of amaranth}

To date, 75 different betalains have been reported from 17 of the 34 families in the Caryophyllales order [51]. Interestingly, no species outside Caryophyllales has been found to produce betalains naturally [52]. Most species in the Amaranthaceae have detectable betalains in organs including root, stem, leaves, and flowers. The ecological functions of betalains are presumed to include attracting pollinators to flowers and possibly protect vegetative cells from stresses. There is a long-standing speculation that these pigments are involved in response to abiotic and biotic stresses, but evidence in support of this idea is scant.

Red beetroot (B. vulgaris) is the only commercial betalain source [52], although amaranths have also been proposed as commercial sources of betalains $[53,54]$. These betalains have some limited use in food coloring and also have several reported health benefits [55]. Chemical and biological experiments have demonstrated the antioxidant capacity of betalains [56]. Cai et al. [53] showed that the betalains from Amaranthaceae were stronger antioxidants than ascorbic acid, rutin, and catechins. Betalains have also been reported to have anticancer properties [57]. As these chemicals scavenge free radicals, it is expected that they may help prevent cancer and cardiovascular disease [55]. Sreekanth et al. [58] showed that betalain induces dose- and time-dependent cell deaths of the human chronic myeloid leukemia cell line (K562). Moreover, betalain extract from $A$. spinosus has a significant antimalarial activity in mice [59]. Pigment extract from beetroot pomace also inhibited the growth of gram-negative bacteria $[59,60]$ and induced zones of reduced growth in Salmonella typhimurium and Bacillus cereus [61]. Thus, amaranth plant is enriched with both nutritional and nutraceutical properties and is a wholesome crop for the future generation.

\section{Concluding remarks}

Amaranth was a staple of the Aztec diet and is described now as a "superfood" in part because of its high protein content and balanced amino acid profile. It produces a large number of seeds loaded with high-quality protein components, squalene, lysine, and many other health benefitting nutritional and nutraceutical components. Amaranth grain is gluten-free, which makes it a desirable food crop for millions of peoples all over the world. This widely distributed and protein-rich pseudo-cereal has a potential to support food security. However, this crop is still not in the mainstream cultivation practices in North America and in many parts of the world. With the increasing understanding of molecular and biological information of this crop, there is a strong basis for amaranth to be considered for our future generation. As we are witnessing the massive increase in human population in the next few decades and global climate change, we strongly believe amaranth has a huge potential to support the global food system.

\section{Conflict of interest}

All authors have read and approved the manuscript for submission. There is no competing interest. 


\section{Author details}

Dinesh Adhikary ${ }^{1 *}$, Upama Khatri-Chhetri ${ }^{2}$ and Jan Slaski ${ }^{3}$

1 University of British Columbia, Kelowna, Canada

2 University of Alberta, Edmonton, Canada

3 InnoTech Alberta, Vegreville, Canada

*Address all correspondence to: dinesh.adhikary@ubc.ca

IntechOpen

(C) 2020 The Author(s). Licensee IntechOpen. This chapter is distributed under the terms of the Creative Commons Attribution License (http://creativecommons.org/licenses/ by/3.0), which permits unrestricted use, distribution, and reproduction in any medium, provided the original work is properly cited. (cc) BY 


\section{References}

[1] Sauer JD. The grain amaranths: A survey of their history and classification. Annals of the Missouri Botanical Garden. 1950;37:561-632

[2] Sauer JD. Revision of the dioecious amaranths. Madrono. 1955;13:5-46

[3] Mosyakin SL, Robertson KR. New infragenic taxa, and combinations in Amaranthus (Amaranthaceae). Annales Botanici Fennici. 1996;33:275-281

[4] Fritz GJ. New dates and data on early agriculture: The legacy of complex hunter-gatherers. Annals of the Missouri Botanical Garden. 1995;82:3-15

[5] Teng XL, Chen N, Xiao XG. Identification of a catalase-phenol oxidase in betalain biosynthesis in red Amaranth (Amaranthus cruentus). Frontiers in Plant Science. 2015;6:1228

[6] Huerta-ocampo JA, Barrera-pacheco A, Mendoza-herna CS, Espitia-rangel E, Mock H, Barba AP. Salt stress-induced alterations in the root proteome of Amaranthus cruentus L. Journal of Proteome Research. 2014;13:3607-3627

[7] Sauer JD. The grain amaranths and their relatives: A revised taxonomic and geographic survey. Annals of the Missouri Botanical Garden. 1967;54:103

[8] Noble AW, Nobel BL. Badaga funeral customs. Anthropos. 1965;60:262-272

[9] Konishi Y, Fumita Y, Ikeda K, Okuno K, Fuwa H. Isolation and characterization of globulin from seeds of Amaranthus hypochondriacus L. Agricultural and Biological Chemistry. 1965;49:1453-1459

[10] Gorinstein S, Moshe R, Greene LJ, Paulo A. Evaluation of four Amaranthus species through protein electrophoretic patterns and their amino acid composition. Journal of Agricultural and Food Chemistry. 1991;39:851-854
[11] Barba de la Rosa AP, Gueguen J, Paredos-Lopez O, Viroben G.

Fractionation procedures, electrophoretic characterization, and amino acid composition of amaranth seed proteins. Journal of Agricultural and Food Chemistry. 1992;40:931-936

[12] Leyva-Lopez NE, Vasco N, Barba de la Rosa AP, Paredes-Lopez O. Amaranth seed proteins: Effect of defatting on extraction yield and on electrophoretic patterns. Plant Foods for Human Nutrition. 1995;47:49-53

[13] Shewry PR, Pandya MJ. The 2S albumin storage proteins. In: Shewry PR, Casey R, editors. Dordrecht, The Netherlands: Kluwer Academic Publishers; 1999. pp. 563-586

[14] Fujiwara T, Nambara E, Yamagishi K, Goto DB, Naito S. Storage proteins. The Arabidopsis book. American Society of Plant Biologists. 2002. pp. 1-12

[15] Higgins TJV. Synthesis and regulation of major proteins in seeds. Annual Review in Plant Physiology. 1984;35:191-221

[16] Gonzalez-Perez S, Arellano B. In: Phillips GO, Williams PA, editors. Handbook of Hydrocolloids. 2nd ed. Sawston, Cambridge: Woodhead Publishing in Food Science, Technology and Nutrition; 2009. pp. 0-27

[17] Youle RJ, Huang AHC. Albumin storage proteins in the protein bodies of Castor bean. Plant Physiology.

1978;61:13-16

[18] Mylne JS, Hara-Nishimura I, Rosengren KJ. Seed storage albumins: Biosynthesis, trafficking and structures. Functional Plant Biology. 2014;41:671-677

[19] Quiroga AV, Martınez EN, Anon MC. Amaranth globulin polypeptide 
heterogeneity. The Protein Journal. 2007; 26:327

[20] Takaiwa F, Kikuchi S, Oono K. The structure of rice storage protein glutelin precursor deduced from cDNA. Federation of European Biochemical Societies. 1986;206:33-35

[21] Pedersen B, Hallgren L, Hansen I, Eggum BO. The nutritive value of amaranth grain (Amaranthus caudatus). Plant Foods for Human Nutrition. 1987;36:325-334

[22] Segura-Nieto M, Vazquez-Sanchez N, Rubio-Velazquez H, Olguin-Martinez LE, Rodriguez-Nester CE, HerreraEstrella L. Characterization of amaranth (Amaranthus hypochondriacus L.) seed proteins. Journal of Agricultural and Food Chemistry. 1992;40:1553-1558

[23] Costea M, DeMason D. Stem morphology and anatomy in Amaranthus L. (Amaranthaceae), taxonomic significance. The Journal of the Torrey Botanical Society. 2001;128:254-281

[24] Adhikary D. Morphological Studies in the Amaranthus hybridus Species Complex (Amaranthaceae: Caryophyllales)2013. p. 109

[25] Coons MP. Relationships of Amaranthus caudatus. Economic Botany. 1982;36:129-146

[26] Park YJ, Nemoto K, Nishikawa T, Matsushima K, Minami M, Kawase M. Waxy strains of three amaranth grains raised by different mutations in the coding region. Molecular Breeding. 2010;25:623-635

[27] Okuno K, Sakaguchi S. Inheritance of starch characteristics in perisperm of Amaranthus hypochondriacus. Journal of Heredity. 1982;73:467-467

[28] Venskutonis PR, Kraujalis P. Nutritional components of amaranth seeds and vegetables: A review on composition, properties, and uses: Nutritional components of amaranth seeds and vegetable. Comprehensive Reviews in Food Science and Food Safety. 2013;12:381-412

[29] Capriles VD, Almeida EL, Ferreira RE, Arêas JAG, Steel CJ, Chang YK. Physical and sensory properties of regular and reduced-fat pound cakes with added amaranth flour. Cereal Chemistry. 2008;85:614-618

[30] Popa O, Elena N, Popa I, Nit S, Dinu-pârvu CE. Methods for obtaining and determination of squalene from natural sources. BioMed Research International. 2015;2015:1-16

[31] Chan P, Tomlinson B, Lee CB, Lee YS. Effectiveness and safety of lowdose pravastatin and squalene, alone and in combination, in elderly patients with hypercholesterolemia. Journal of Clinical Pharmacology. 1996;36:422-427

[32] Trichopoulou A, Katsouyanni K, Stuver S, Tzala L, Gnardellis C, Rimm E, et al. Consumption of olive oil and specific food groups in relation to breast cancer risk in Greece. Journal of the National Cancer Institute. 1995;87:110-116

[33] Keys A. Mediterranean diet and public health: Personal reflections. American Journal of Clinical Nutrition. 1995;61:1321-1323

[34] Owen RW, Mier W, Giacosa A, Hull WE, Spiegelhalder B, Bartsch H. Phenolic compounds and squalene in olive oils: The concentration and antioxidant potential of total phenols, simple phenols, secoiridoids, lignans and squalene. Food and Chemical Toxicology. 2000;38:647-659

[35] León-Camacho M, GarcíaGonzález DL, Aparicio R. A detailed and comprehensive study of amaranth (Amaranthus cruentus L.) oil fatty 
profile. European Food Research and Technology. 2014;213:349-355

[36] Berganza BE, Moran AW, Rodríguez MG, Coto NM, Santamaría M, Bressani R. Effect of variety and location on the total fat, fatty acids and squalene content of amaranth. Plant Foods for Human Nutrition. 2003;58:1-6

[37] He HP, Corke H. Oil and squalene in amaranthus grain and leaf. Journal of Agricultural and Food Chemistry. 2003;51:7913-7920

[38] Peter K, Gandhi P. Rediscovering the therapeutic potential of Amaranthus species: A review. Egyptian Journal of Basic and Applied Sciences. 2017;4:196-205

[39] Jimoh MO, Afolayan AJ, Lewu FB. Suitability of Amaranthus species for alleviating human dietary deficiencies. South African Journal of Botany. 2018;115:65-73

[40] Repo-Carrasco-Valencia R, Hellström JK, Pihlava J-M, Mattila PH. Flavonoids and other phenolic compounds in Andean indigenous grains: Quinoa (Chenopodium quinoa), kañiwa (Chenopodium pallidicaule) and kiwicha (Amaranthus caudatus). Food Chemistry. 2010;120:128-133

[41] Fasano A, Catassi C. Current approaches to diagnosis and treatment of celiac disease: An evolving spectrum. Gastroenterology. 2001;120:636-651

[42] De La Barca AMC, Rojas-Martínez ME, Islas-Rubio AR, Cabrera-Chávez F. Gluten-free breads and cookies of raw and popped amaranth flours with attractive technological and nutritional qualities. Plant Foods for Human Nutrition. 2010;65:241-246

[43] Shewry PR, Hey SJ. Do we need to worry about eating wheat? Nutrition Bulletin. 2016;41:6-13
[44] Gallagher E, Kunkel A, Gormley TR, Arendt EK. The effect of dairy and rice powder addition on loaf and crumb characteristics, and on shelf life (intermediate and long-term) of gluten-free breads stored in a modified atmosphere. European Food Research and Technology. 2003;218:44-48

[45] Rizzello CG, Coda R, De Angelis M, Di Cagno R, Carnevali P, Gobbetti M. Long-term fungal inhibitory activity of water-soluble extract from Amaranthus spp. seeds during storage of gluten-free and wheat flour breads. International Journal of Food Microbiology. 2009;131:189-196

[46] Fiorda FA, Soares MS, da Silva FA, Grosmann MVE, Souto LRF.

Microstructure, texture and colour of gluten-free pasta made with amaranth flour, cassava starch and cassava bagasse. Food Science and Technology. 2013;54:132-138

[47] Cabrera-Chávez F, Calderón de la Barca AM, Islas-Rubio AR, Marti A, Marengo M, Pagani MA, et al. Molecular rearrangements in extrusion processes for the production of amaranthenriched, gluten-free rice pasta. LWT-Food Science and Technology. 2012;47:421-426

[48] Kurek MA, Karp S, Wyrwisz J, Niu Y. Physicochemical properties of dietary fibers extracted from glutenfree sources: Quinoa (Chenopodium quinoa), amaranth (Amaranthus caudatus) and millet (Panicum miliaceum). Food Hydrocolloids. 2018;85:321-330

[49] Salcedo-Chávez B, Osuna-Castro JA, Guevara-Lara F, DomínguezDomínguez J, Paredes-López O. Optimization of the isoelectric precipitation method to obtain protein isolates from amaranth (Amaranthus cruentus) seeds. Journal of Agricultural and Food Chemistry. 2002;50:6515-6520 
[50] Lyapkova NS, Loskutova NA, Maisuryan AN, Mazin VV, Korableva NP, Platonova TA, et al. Transformed potato plants carrying the gene of the antifungal peptide of Amaranthus caudatus. Applied Biochemistry and Microbiology. 2001;37:349-354

[51] Khan MI, Giridhar P. Plant betalains: Chemistry and biochemistry. Phytochemistry. 2015;117:267-295

[52] Strack D, Vogt T, Schliemann W. Recent advances in betalain research. Phytochemistry. 2003;62:247-269

[53] Cai Y, Sun M, Corke H. Antioxidant activity of betalains from plants of the Amaranthaceae. Journal of Agricultural and Food Chemistry. 2003;51:2288-2294

[54] Cai Y-Z, Sun M, Corke H. Characterization and application of betalain pigments from plants of the Amaranthaceae. Trends in Food Science \& Technology. 2005;16:370-376

[55] Gengatharan A, Dykes GA, Choo WS. Betalains: Natural plant pigments with potential application in functional foods. LWT-Food Science and Technology. 2015;64:645-649

[56] Borkowski T, Szymusiak H, Gliszczyńska-Rwigło A, Rietjens IMCM, Tyrakowska B. Radical scavenging capacity of wine anthocyanins is strongly $\mathrm{pH}$-dependent. Journal of Agricultural and Food Chemistry. 2005;53:5526-5534

[57] Esatbeyoglu T, Wagner AE, Motafakkerazad R, Nakajima Y, Matsugo S, Rimbach G. Free radical scavenging and antioxidant activity of betanin: Electron spin resonance spectroscopy studies and studies in cultured cells. Food and Chemical Toxicology: An International Journal Published for the British Industrial Biological Research Association. 2014;73:119-126
[58] Sreekanth D, Arunasree MK, Roy KR, Chandramohan Reddy T, Reddy GV, Reddanna P. Betanin a betacyanin pigment purified from fruits of Opuntia ficus indica induces apoptosis in human chronic myeloid leukemia cell line-K562. Phytomedicine. 2007;14:739-746

[59] Hilou A, Nacoulma OG, Guiguemde TR. In vivo antimalarial activities of extracts from Amaranthus spinosus L. and Boerhaavia erecta L. in mice. Journal of Ethnopharmacology. 2006;103:236-240

[60] Čanadanović-Brunet JM, Savatović SS, Gordana S. Antioxidant and antimicrobial activities of beet root pomace extracts. Science. 2011;29:575-585

[61] Velićanski AS, Cvetković DD, Markov SL, Vulić JJ, Djilas SM.

Antibacterial activity of Beta vulgaris L. pomace extract. Acta Periodica Technologica. 2011;42:263-269 
Section 2

\section{Amaranth as a Functional Food}





\title{
Potential of Amaranth in Alleviating Malnutrition in Indonesia
}

\author{
Muhammad Ikhsan Sulaiman and Rita Andini
}

\begin{abstract}
An extricable link between biodiversity and nutrition security has been magnified by many researchers over the past three decades as humans have utilized more than 10,000 edible species from the totally expected to be 300,000 plant species. A strong reliance on handful of major crops has inherent agronomic, ecological, and nutritional risks and is probably unsustainable in the long run. On the other hand, global food production is still a main challenge for the future of mankind. New strategies such as the exploration and utilization of underutilized crops have been affirmed as some of the promising fields to meet world food needs. As such crop, amaranth (Amaranthus spp.) has the potential to be prospected as potential plant in alleviating malnutrition in most of the developing countries, especially in Indonesia (location: $6^{\circ} \mathrm{N}$ to $11^{\circ} \mathrm{S}$ and from $95^{\circ} \mathrm{W}$ to $141^{\circ} \mathrm{E}$ ) also known as the biggest archipelago country in the world. Malnutrition with its two constituents of protein-energy malnutrition and micronutrient deficiencies has been recognized as a persisting public health challenge in many developing countries, e.g., Africa, Asia, and Indonesia. This paper highlights the advantage of amaranth in terms of their nutrition and further application in nutraceuticals.
\end{abstract}

Keywords: grain, malnutrition, protein, vegetable, weedy types

\section{Introduction}

An extricable link between biodiversity and nutrition security has been magnified by many researchers over the past three decades as human has utilized more than 10,000 edible species from the totally expected to be 300,000 plant species. Nevertheless, there are only few or up to 150 of those edible ones that have been commercialized significantly on the global scale. Among huge alternative crops existing, humans depend only on 12 plant species that supply dietary energy with a strong dependency on 4 species only, namely, rice, wheat, maize, and potato. Thus, reliance on handful of major crops has inherent agronomic, ecological, and nutritional risks and is probably unsustainable in the long run [1].

On the other hand, global food production is still a main challenge for the future of mankind. Rapid deforestation, feeding the world population, and climate change have made it to be much more challenging [2]. The dramatic decline of tropical rain forests and habitat destruction aiming for settlement, cash crop plantation such as oil palm and rubber, and building of infrastructures would lead to massive biodiversity loss. This consequently would adversely affect human's life quality [1]. 
While the area of planting has been dramatically reduced, on the opposite, the agricultural production is expected to be increased by $70 \%$ as a result of a $40 \%$ increase in world population [1]. The impact of climate change for most of the developing countries would exacerbate the food security challenges due to higher frequency of droughts and flood [3].

\section{Potential of underutilized crops}

It is mainly known that almost 900 million people are hungry worldwide. In adjacent to that, 195 million children under 5 years of age are stunted. Of this total number, $90 \%$ live in 36 countries, mostly in the developing ones [4]. New strategies such as the exploration and utilization of underutilized crops as well their genetic assessment and plant genetic diversity interlinked with plant breeding have been affirmed as some of the promising fields to meet the world food needs [4]. Thus, re-directing the global agricultural system to ensure better nutrition is critical. The current global trend in agricultural system produces enough food quantitatively in total; however, the rapidly growing population demands not only an increase in quantity but also in terms of highly nutritious food with good protein quality $[4,5]$. In regard to this, it is imperative that both researchers and development professionals apply new and sustainable approaches to enhance the quality and to increase the variety of food produced and consumed around the world. Other innovative methodologies embedded in agriculture and food science will also be essential to upscale dietary diversity and nutrition [4].

Over the past two decades, moreover, nutraceuticals have been much more explored as some vegetables and fruits bear great potential to be further prospected as antioxidant, anticancer, anti-allergic, and antihypertensive agent and as a food for patients with autoimmune diseases [6]. Thus, an alternative approach other than the major staple crops, valorization of valuable, however underutilized, crops have been in the focus of many (food) researchers and agronomists [1]. In many areas, such underutilized particularly the weedy edible types have been playing a major role in fulfilling the micro- and macronutrients and protein requirements [7]. Therefore, this paper highlights the potential and utilization of Amaranthus sp. in developing countries, especially in the most densely populated countries such as in Indonesia.

\section{Indonesia $v s$. malnutrition}

Indonesia - the biggest world archipelago-is located at the tropical equator and situated between the Indian and Pacific oceans and the Asian and Australian continent. It extends from latitudes $6^{\circ} \mathrm{N}$ to $11^{\circ} \mathrm{S}$ and from $95^{\circ} \mathrm{W}$ to $141^{\circ} \mathrm{E}$. The greatest distance from west to east and north to south is $5110 \mathrm{~km}$ and $1888 \mathrm{~km}$, respectively [8]. The archipelago consists of almost 17,504 islands, with five major islands, namely, Borneo, Sumatra, Papua, Celebes, and Java (from the biggest one). While smaller islands such as Bali and Nusa Tenggara are stretched starting from the middle to the eastern part of Indonesia.

Almost $65 \%$ of its population live in rural areas and depend highly their livelihood on the agricultural basis activities as one of the five biggest gross domestic product (GDP) contributions is based from agriculture and cash crop such as palm oil and rubber. The GDP from this sector grew at 2.3\%, annually. The major staple crops are rice, which are mostly consumed by the western part of Indonesia, while the eastern parts such as Nusa Tenggara islands have a distinct climate with a much warmer and drier climate and are suitable for many savannas. Thus, their staple 
crops are slightly distinct, and the inhabitants depend a lot on maize and cassava as they are much more suitable to a drier environment.

The major crops grown in Indonesia are rice, maize, soybean, peanut, cassava, and chili; meanwhile, the major vegetables grown in the country are chili; yard-long bean; cabbage; kidney bean; cucumber; Chinese cabbage; green mustard; amaranth (A. tricolor L.), which is mostly perceived as "spinach"; French bean; eggplant; garlic; and carrot. Most of the vegetable cultivation is mainly concentrated on Java Island as their infrastructures are better prepared rather than outside Java or any other dispersed islands. Within the agricultural sector, the food crop sub-sector employed about 27 million people or equal to $75 \%$ of the agricultural labor force [8].

It is also accounted as the fourth biggest world population with $270,054,853$ people. The population is unevenly dispersed within the archipelago. There are 32 provinces stretching from Aceh to Irian Jaya; however, about $60 \%$ of it resides on Java-the smallest island among the big five-but Kalimantan which accounts for $28 \%$ of Indonesia's total land area, as a matter of fact, is home to only $5 \%$ if the total population. The population density on Java is about $800-1000$ people per $\mathrm{km}^{2}$, but Irian Jaya has only 7 people per $\mathrm{km}^{2}$ [8]. In terms of economic, Indonesia is classified as one of the three biggest Southeast Asian countries-after Singapore and Malaysia - with a vibrant economic growth, namely, in the range of 5.1\%, yearly [9].

The United Nations Food and Agriculture Organization (UN-FAO) agrees that to secure access for all to adequate supplies of food that is healthy, safe, and of high quality, and to do so in an environmentally sustainable manner. Nevertheless, with the rapidly growing population, how our current global food system will sustain itself remains a challenge. Additional (man-made) external factors, such as climate change, urbanization, social conflict including refugee from war-inflicted countries mostly in Africa and in the Middle East, extreme poverty, as well as overly stressed ecosystems and biodiversity, make it more obvious that there has never been a more urgent time for collective action to address food and nutrition security at the global stage [4].

In terms of biodiversity richness, Indonesia is counted as the second biggest biodiversity hotspots in the world, and ranked after the Amazon basin in South America. Despite its biodiverse-rich environment and economic growth as it was mentioned before, it is estimated that 87 million of population in Indonesia remain vulnerable to food insecurity [10]. Multi-stakeholders in Indonesia have been aware that nutrition must be at the forefront of the major goals of agriculture and production systems, so that agricultural biodiversity can serve as an avenue to improve dietary and nutritional diversity as well as in improving life quality and maintaining health [4]. Meanwhile, the agricultural biodiversity itself is perceived as biological variety exhibited among crops, animals, and other organisms used for food and agriculture, in conjunction to the web of relationships that bind these forms of life at ecosystem, species, and genetic levels. This includes not only crops and livestock directly relevant to agriculture but also many other organisms that have indirect effects on agriculture, such as soil fauna, weeds, pests, and predators [4].

Malnutrition with its two constituents of protein-energy malnutrition and micronutrient deficiencies has been recognized as a persisting public health challenge in many developing countries, e.g. in Africa, Asia, and including Indonesia. It is the direct cause of about 300,000 deaths per year and is indirectly responsible for about half of all deaths in young children. Certainly, poverty, political and economic situation in one country, and unhealthy environment including bad sanitation have worsened the problem [10]. Moreover, the loss affected due to malnutrition in Indonesia has been estimated to be $2-3 \%$ of Indonesia's gross domestic products or GDP or equal to more than US\$ 5 billion yearly as a result of poor education standard, low IQ score, reduced productivity over time, and diminishing physical capability. 


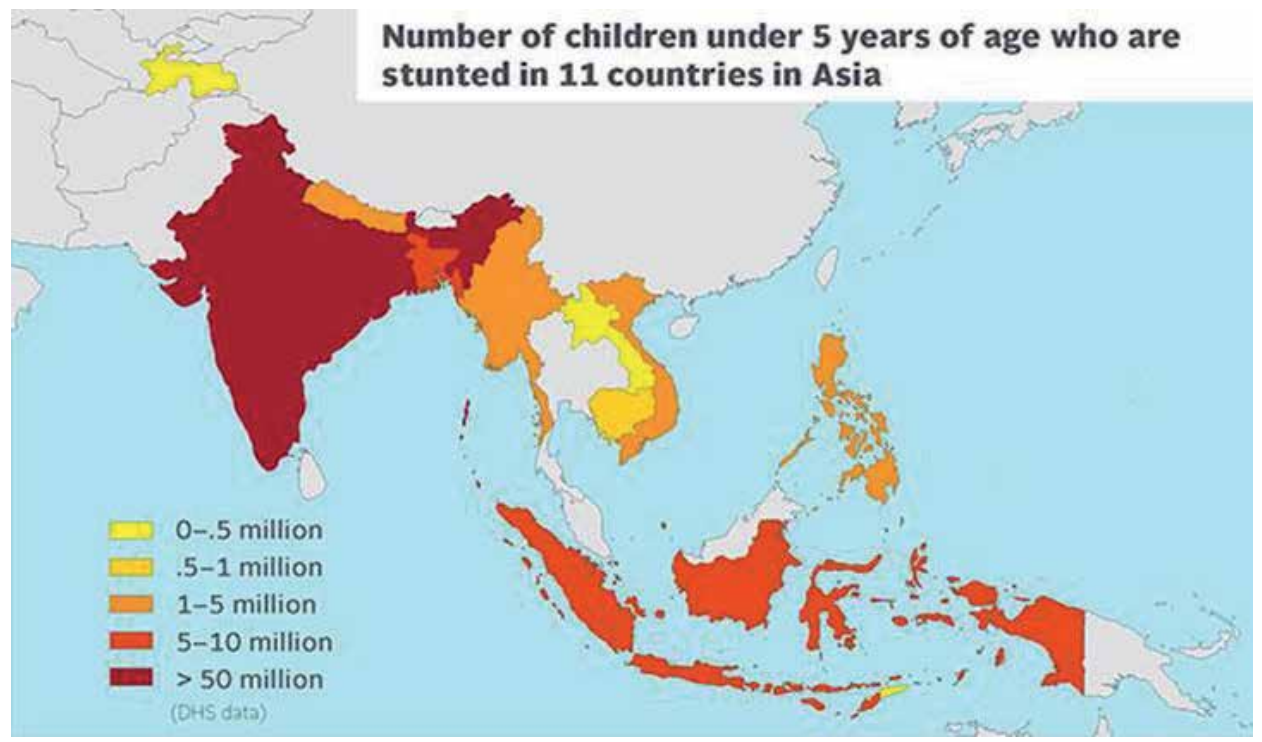

Figure 1.

Malnutrition map in Asia (source: [12]).

The physical condition of malnourished children is indicated generally with wasting and stunting. Wasting children loss their weight progressively. Chronical weight loss among children leads to stunting. It has been reported that over the past 6 years, the stunting situation has not yet been improved as there are $37 \%$ children under 5 years in Indonesia are malnourished, while more than $12 \%$ of children are suffering from wasting; with most of them live in the rural areas [10]. According to a USDA-based technical report, Indonesia is on an "alert" regarding the malnutrition among children under 5 years of age as indicated with the orange color (Figure 1). Furthermore, the highest prevalence number was found on the drier part of Indonesia such as East Nusa Tenggara with up to 58\% [11].

\section{What is amaranth?}

The family of Chenopodium including amaranth is known as a good source of protein-rich green leafy vegetables [13]. Amaranth in the ancient Greek means "everlasting" or "unfading." The plant occurred about 5000-7000 years ago in the New World with A. hybridus as the putative progenitor. Out of 70, most of them are native to the Americas, while only 15 species are recognized to be native to Africa, Europe, and Asia. Phylogenetically, the genus was originally clustered into two sections: Amaranthus and Blitopsis Dumort. Later on, it was divided into three sections, and more recently, the genus has been distinguished into three sub-genera and nine sections, based on inflorescence and flower characters [14]. The most recent finding has separated it into three sub-genera, namely, Acnida, Amaranthus, and Albersia, by using genome-wide molecular markers [15].

Taxonomically, Amaranthus sp. is often difficult to characterize as it has few useful distinguishing features among the large number of species. The so-called Amaranthus hybridus complex includes the three grain species and their two potential wild ancestors: $A$. hybridus and $A$. quitensis. These five species are proposed to be closely related and readily cross within the complex due to a specific hybridization character, which is also often regarded as common phenomenon in this genus. Thus, outcrossing rates ranging from 5 to $30 \%$ has been reported [16]. 
Meanwhile, a lower rate was performed by $A$. caudatus L., which was in the range of $25 \%$, solely [16]. Although the taxonomic identification in Amaranthus is confusing, genetic markers are expected to provide a distinct and inexpensive solution for species identification. Based on the recent studies using simple sequence repeat (SSR) marker and genotyping by sequencing, it is commonly agreed that $A$. hybridus is a common ancestor to the three cultivated grain amaranths, although it has not yet been fully resolved if the three species occurred from one single or multiple domestication event. However, phylogenetic and population genetic analysis suggested a clear geographic grouping of $A$. hybridus from South America with $A$. quitensis and $A$. caudatus and $A$. hybridus from central America with the two northern crop species. This suggests separate domestication events in the different regions [15].

The utilization of amaranths depends greatly on geographical preferences. People on the humid tropical continents such as Asia and Africa use the young and succulent leaves as vegetables, meanwhile people on the northern hemisphere consume the grain amaranths. Due to its vivid color, amaranths are also cultivated as ornamentals. Most amaranth is mainly found in the form of weedy types including true weeds such as $A$. retroflexus $\mathrm{L}$. Besides the two main types, some dual-purpose types, such as $A$. cruentus $\mathrm{L}$. and $A$. caudatus, also exist. The dual purpose means that both their young, succulent leaves and their grains are also edible. They are mostly appreciated in most of African and Asian countries [14]. Here, we tried to highlight the two cultivated types of amaranth and the potential of the weedy edible ones.

Several morphological studies have been conducted in order to clarify its taxonomy, and several systematic botanical revisions based on leaf anatomy and morphology, pericarp structure, stem morphology, and anatomy have been also proposed [14]. A high variability of morphological variation and high nutritional qualities were reported in the Indonesian weedy accessions, particularly the $A$. dubious that may exist as diploid ( $n=16$ or $n=17$ ), or it may sometimes exist as natural tetraploid as this was supported with distinct phenotypical features found in polyploidy: e.g., different leaf texture, bigger leaf size, darker green color, and much resembling spinach (Spinacia oleracea). Polyploidy means the heritable condition of having more than two complete sets of chromosome and is counted as an important evolutionary and speciation process in many plants and some animals. In amaranths, polyploidy would affect morphological performance such as vigorous plant performance, biomass heterosis, and shorter and thicker stemmed than those normal diploids, up to increase of seed size, although with no significant changes in the nutritional content. However, no polyploids were found by the Indonesian weedy edible based on the flow cytometer measurement [17].

In terms of its adaptability, amaranth possesses wide adaptability due to its $C_{4}$ plants' characteristics meaning that they are highly productive plants. It can be cultivated from temperate to tropical conditions and distributed in at least 50 tropical countries in Asia and Africa [13]. Andini [18] proposed that it is mainly classified as short-day plants, meaning that an eight hour of photoperiod is required to make them to flower. However, the vegetable types resemble the long-day plant as well. Based on the field experiment conducted under temperate regions with different photoperiods, it was revealed that they require 12 hours of photoperiod in order to initiate its flowering. Such distinct features support the wide ecogeographical distribution in amaranth at the global level.

\section{Nutritional values in amaranth}

The incorporation of high-protein and mineral-containing crop would improve dietary diversification and enhance food quality or nutritional values. Amaranth is 
acknowledged as rich and inexpensive source of dietary fiber, mineral, vitamins, protein, and antioxidants [19]. As it has been highlighted previously that there are up to 70 species included in the genus, however, only 17 species are classified as edible, and they accounted as the most important leafy vegetables with excellent nutrition for the lowland tropics of Africa and Asia [13].

From the agronomical point of view, amaranth can be grown successfully under varied soil and agroclimatic conditions of tropical lowlands with an elevation ranging from 100 to $800 \mathrm{~m}$ a.s.l. up to subtropical region such as the Indo-Gangetic Plains, which has sharp congruences in temperatures or between summer and winter seasons. In India, amaranth is being known as "Kharif" crop, and during summer season with the temperature reaching up to $45^{\circ} \mathrm{C}$, among all Indian vegetables available in the region, only amaranth can endure such high temperature. This feature shows the heat resistance in amaranth [20]. In Indonesia, cultivation area can be divided into three categories: (a) lowland (altitude 0-200 m), (b) medium (altitude 201-800 m), and (c) highland (altitude above $800 \mathrm{~m}$ ) with almost $30 \%$ plantation in Indonesia located on the highlands [8].

Amaranth in Indonesia is very popular and ranked as the third mostly produced green leafy vegetables. The number of amaranth's production is ranked as the third in Indonesia (Figure 2). Vegetable amaranth is part of the Indonesian's daily dishes, and its taste resemblance to that of spinach. It is mostly cultivated on small plots less than one hectare belonging to subsistence farmer. The plots are located along the riverside or open fields scattered at the periphery of suburban areas and can be harvested within an interval of 4 to 6 weeks per harvest season. The yield is in the range of 2-5 tons ha ${ }^{-1}$ per harvest season, but it is available throughout the year, frequently traded in Indonesian traditional markets and usually sold in small bundles consisting of 10-20 plants. Growing amaranth is counted as one of the economically important vegetables in Indonesia. Moreover, vegetable amaranths provide a high concentration of vitamin $\mathrm{A}$, and their nutritional benefit was incorporated by the eradication of children's dark blindness in 1973-1980 in Indonesia [13].

Siemonsma and Piluek in [13] estimated that up to 225 primary use vegetables and more than 100 wild species exist, including a large number of weedy

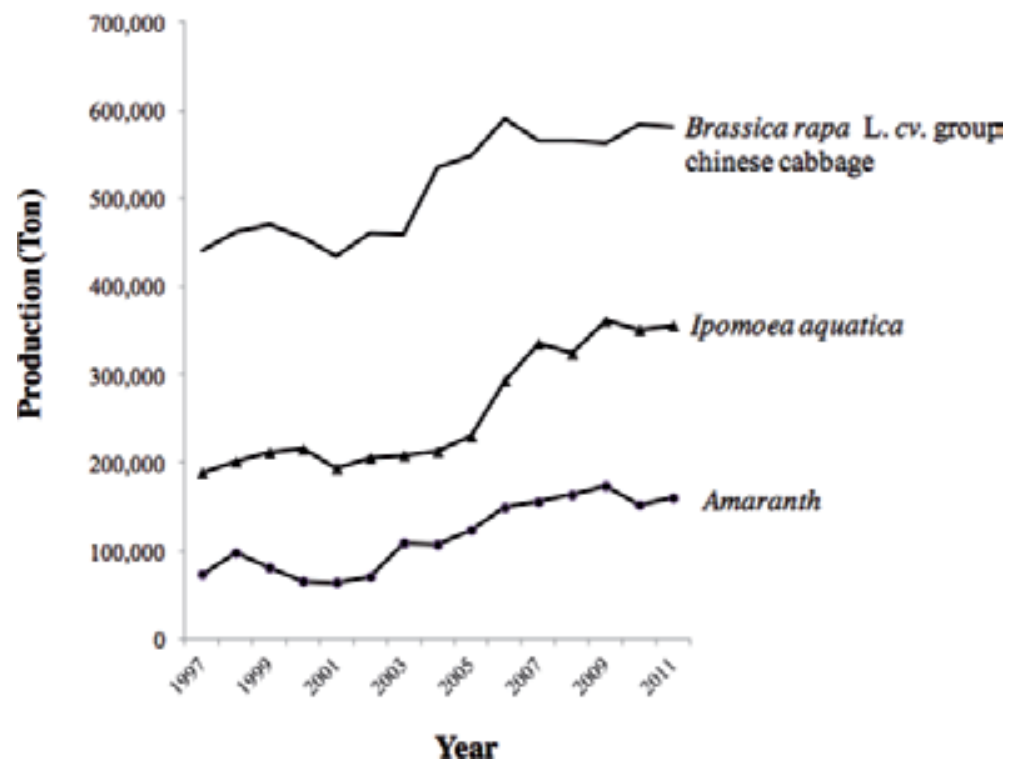

Figure 2.

Production number of three major leafy vegetables in Indonesia [source: depicted from 37]. 
companions. The high biodiversity in Indonesia may open opportunities for breeding new type of amaranths with desired characters such as high-protein content. In terms of protein nutritional quality, some parameters, such as protein digestibility, available lysine, protein utilization, and the composition of well-balanced essential amino acid in food sources, especially the availability of lysine, methionine, and tryptophan, are counted as important aspects [5]. Generally, vegetable amaranths have received lower attention than the grain ones [21]. Although their nutritional superiority is not too much distinct from the grain ones as the leaves of amaranths were found to be a good source for lysine, which is required during the growth of young children or under 5 years old.

Research on the extent of the diversity of amaranths aiming to choose some of the weedy types as prospective genetic resources for useful traits has been conducted. The work reported the superiority of weedy edible amaranths harvested in the wild of Gayo Highlands, such as A. blitum L., A. dubious, and A. viridis, compared to the most commercial one (A. tricolor L.). Until now, they are still being classified as underutilized and particularly used as famine food. Therefore, screening of potential lines with novel characteristics in amaranths should be initiated and promoted for any further breeding and conservation attempts. In most of

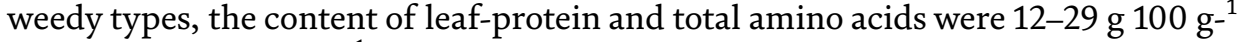
DM and 84-93 g $100 \mathrm{~g}-^{1}$ DW protein, respectively. Such amount of protein was 2.3 higher than the most cultivated type (A. tricolor L.) [22]. In terms of adaptability, they are also more robust as they require very low agricultural input, easy nursery, and heat resistance, and all these have made them a potential to be incorporated as parental lines for high-protein amaranth [22].

Furthermore, a large number of trace elements such as iron $(\mathrm{Fe})$, calcium $(\mathrm{Ca})$, phosphorus $(P)$, and zinc $(Z n)$ were found in amaranth in the range of $15,239,33$, and $0.6 \mathrm{mg}$ per $100 \mathrm{~g}$ fresh leaves. Such trace amounts are significantly needed in order to establish a wide range of metabolism or functions in the body. Besides, amaranth is also known to be a good source of ascorbic acid and $\beta$-carotene with values ranging from 39 to $111 \mathrm{mg}$ and 5.41 to $8.3 \mathrm{mg}$ per $100 \mathrm{~g}$ fresh leaves, respectively. It can be concluded that a consumption of $100 \mathrm{~g}$ of fresh amaranth in the diets is recommended-particularly for those vegetarian - in order to fulfill daily nutritional requirements $[19,20]$.

Despite the health positive benefit effects exhibited in Amaranth, the antinutritive content such as oxalate and nitrate might be the hindrances in exploiting amaranth as food resource. The leaves were reported to have a relatively high amount of oxalate, which is in the range of $7.8-12.0 \mathrm{mg} \mathrm{g}^{-1}$ and $1.8-4.4 \mathrm{mg} \mathrm{g}^{-1}$ of nitrate. Although it is known that the level of toxicity of oxalate is quite low and a minimal lethal dose for humans is considered to be in the range of $5 \mathrm{~g}$ for an adult, vegetables are mostly found as the source of high levels of nitrate because the content of this salt could reach up to $3.25 \%$. Such high values might be harmful to humans as nitrate has been described as potential carcinogenic via transforming first to nitrite and then to nitrosamine [23]. Therefore, cooking properly and discarding water from boiling the vegetables might be counted as preventive measurement.

\section{Nutraceuticals in amaranth}

Since 1980, Amaranthus has been rediscovered as potential crop for the twentyfirst century with promising food ingredients that can substitute cereal proteins [24]. Generally, the three major crops (rice, wheat, and maize) provide the largest proportion of daily nutrition and calories for billions of people, but they lack of essential minerals and vitamins for a balanced nutrition. Because of its similarity 
with "true cereals," thus, amaranth is referred as "pseudocereals," having a superior nutritional quality, and highly recommended for those who are suffering celiac disease or from hypersensitivity against gluten or prolamin content [25].

Amaranth can be grown for their seeds and are called as grain amaranths. The three most representing are $A$. cruentus, $A$. caudatus, and $A$. hypochondriacus. Since 1980 , it has been rediscovered due to its extra ordinary nutritional characteristics, particularly as an alternative crop when cereals and vegetables can't be grown due to abiotic challenges [24]. The protein content found in the grain amaranth was relatively high, namely, $13-19 \% \mathrm{DM}$; thus, this is close to the optimum required in the human diet as described by the World Health Organization (WHO) and the Food and Agriculture Organization (FAO) [26]. Moreover, the amount of lysine and sulfur is two to three times higher than wheat, rice, and maize and greater than legumes, respectively. Recent reviews were published, and they reported the health benefit effects derived from the oil or grain, such as reducing blood pressure activity (hypocholesterolemic), enhancing the immune system, antitumor effect, action on reducing glucose levels in blood, effects on enhancing liver function, reducing blood pressure, anti-allergic, and possessing antioxidant activity against cancer [25].

The medicinal importance of amaranth has been known since the ancient time. In Russia, it has been applied as a mixture with tea as it can be used in prophylactic and therapeutic purposes as well as applied in stomach cleaning, diuretic, cough, headaches, and tumor. These advantageous health effects are often attributed to different antioxidant components [21]. Antioxidants are recognized as important nutraceuticals, which bring health-positive impacts because of phenolic compounds that are attributed with radical-scavenging activity [27]. The oil in amaranth is an important source as an effective natural antioxidant supplement as it contains a relatively high amount of unsaturated fatty acids_-such as linoleic acid, oleic acid, a small amount of linolenic acid, and a unique presence of squalene. Thus amaranth oil can be applied as supplements and beneficial for correcting hyperglycemia as part of an antioxidant therapy [21]. Another niche application is that amaranth can be considered as food colorants, as it contains betacyanin and betalains. These natural pigments can be used as dyes, and they also have antioxidant, anti-inflammatory, and anti-aging [21, 25]. A relatively high amount of betacyanins (305 mg per $110 \mathrm{~g}$ ) can be obtained from spiny amaranth (A. spinosus L.). It is still classified as true weeds, although it is also classified as medicinal plants in some regions [28].

The seed flour of $A$. hypochondriacus was attributed with antioxidant activity; some of them are rutin $\left(4.0-10.1 \mu \mathrm{g} \mathrm{g}^{-1}\right)$, nicotiflorin $\left(4.8-7.2 \mu \mathrm{g} \mathrm{g}^{-1}\right)$, and isoquercitrin $\left(0.3-0.5 \mu \mathrm{g} \mathrm{g}^{-1}\right)$, and they have high potential to be prospected as bioactive agent applied in cancer treatment. In other sources, it was reported that rutin (quercetin-3-O-rutinoside) and quercetin (the precursor of rutin) are ubiquitous flavonoids and usually found in nature. Rutin may be useful for the prevention and treatment of colorectal carcinogenesis, while quercetin could be a constituent of chemotherapeutic drugs for prostate and skin cancer treatment due to its growth inhibitory effect to tumor cells. The amount of rutin in seeds ranged from 0.08 to $24.5 \mathrm{~g} \mathrm{~kg}^{-1}$, and the grain species belonging to A. hybridus and A. cruentus were found to be the best sources of rutin [21]. Meanwhile, the leaves had a higher amount, namely, up to $24.5 \mathrm{~g} \mathrm{~kg}^{-1}$ dry matter. Lunasin, a kind of bioactive peptide sequence found in the seed of A. hypochondriacus, is closely attributed with anticarcinogenic properties. Its concentration was found to be $11.1 \mu \mathrm{g} \mathrm{g}^{-1}$ in the extracted protein. Its anticarcinogenic property has been researched in vitro by inducing apoptosis against HeLa cells using the glutelin extract digested with trypsin, and it can inhibit the transformation of NIH-3 T3 cells to cancerous nodules [25]. 
Moreover, tocopherols (counterparts of vitamin E) and tocotrienols available in the seed are also closely linked with antitumor activity, antioxidant activity, cholesterol-reducing agent, and serum cholesterol regulatory levels that may reduce the synthesis of low density lipoprotein cholesterol between 30 and 70\% attributed with the oil of $A$. cruentus. The amounts were found to be in the range of 8-546 ppm. Lectins contained in different varieties of Amaranthaceae including in $A$. hypochondriacus were reported having a positive immunosuppression and cytotoxicity, and they are widely applied in immunology, cell biology, and cancer research [25].

\section{Conclusions}

Amaranth, which is originated in America, has a wide ecogeographical distribution. It is a multipurpose plant, whose succulent leaves are tasty and tender, while its grains are consumed as cereals. Both plant parts are edible and can have an extraordinary amount of protein and essential amino acids, especially the lysine. This is found in very limiting numbers especially among the true cereal plants; due to this excellent nutritional character, amaranth can be prospected as a potential plant for the twenty-first century in combating malnutrition problem in many developing countries, especially in Indonesia. Indonesia, as the third big biodiverserich country in the world that also faces the malnutrition problem, especially among young children, should utilize the untapped genetic variation richness of Amaranthus and further explore the variety that exists as potential parental lines targeting to breed amaranth with high-protein content.

\section{Acknowledgements}

This research was conducted in Japan during 2010-2013 under the support from the Japanese Monbukagakusho (MEXT) scholarship. Moreover, the authors would like to extend their sincere gratitude to Dr. David M. Brenner for providing the seeds freely from the ARS USDA, Iowa. Moreover, the authors would like to thank the local farmers that they visited on Sumatra and Java for their sincere assistance and help by providing local amaranth seeds. The authorship criteria are listed in our Authorship Policy: https://www.intechopen.com/page/authorship-policy.

\section{Conflict of interest}

The authors declare no conflict of interest. 


\section{Author details}

Muhammad Ikhsan Sulaiman ${ }^{1 *}$ and Rita Andini ${ }^{2}$

1 Agricultural Products Technology Department, Faculty of Agriculture, Syiah Kuala University, Banda Aceh, Indonesia

2 Forestry Department, Faculty of Agriculture, Syiah Kuala University, Banda Aceh, Indonesia

*Address all correspondence to: ikhsan.sulaiman@unsyiah.ac.id

\section{IntechOpen}

(C) 2020 The Author(s). Licensee IntechOpen. This chapter is distributed under the terms of the Creative Commons Attribution License (http://creativecommons.org/licenses/ by/3.0), which permits unrestricted use, distribution, and reproduction in any medium, provided the original work is properly cited. (cc) BY 


\section{References}

[1] Ebert AW. Potential of underutilized traditional vegetables and legume crops to contribute to food and nutritional security, income and more sustainable production systems. Sustainability. 2014;6:319-335. DOI: 10.3390/ su6010319

[2] Hoisington D, Khairallah M, Reeves T, Ribaut JM, Skovmand B, Taba S, et al. Plant genetic resources: what can they contribute toward increased crop productivity? Proceedings of the National Academy of Sciences of the United States of America. 1999. Vol. 96. pp. 5937-5943

[3] FAO. The state of agricultural commodity markets. Agricultural trade, climate change and food security. Rome: FAO; 2018. 92 p. Available from: http:// www.fao.org/3/I9542EN/i9542en.pdf

[4] Bioversity International, Nutrition Strategy 2011-2021: Resilient food and nutrition systems: analyzing the role of agricultural biodiversity in enhancing human nutrition and health. 2015. 4 p. www.bioversityinternational.org

[5] Drzewiecki J, Delgado-Licon E, HaruenkitR, PawelzikE,Martin-BellosoO, Park YS, et al. Identification and differences of total proteins and their soluble fractions in some pseudocereals based on electrophoretic patterns. Journal of Agricultural and Food Chemistry. 2003;51:7798-7804

[6] Caselato-Sousa VM. Amaya-Farfán, State of knowledge on amaranth grain: A comprehensive review. Journal of Food Science. 2012;77(4):93-104. DOI: 10.1111/j.1750-3841.2012.02645.x

[7] Termote C, Meyi MB, Djailo BD, Huybregts L, Lachat C, Kolsteren P, et al. A biodiverse rich environment does not contribute to a better diet: a case study from DR Congo. PLoS One. 2012;7(1):E30533
[8] Darmawan DA, Pasandaran E, Dynamics of vegetable. 1993. $171 \mathrm{p}$. Available from: https://pdf.usaid.gov/ pdf_docs/pnacj643.pdf [Accessed: 18 July 2019]

[9] Available from: https://en.wikipedia. org/wiki/Indonesia [Accessed: 18 July 2019]

[10] Müller O, Krawinkel M. Review: Malnutrition and health in developing countries. JAMC. 2005;173(3):279-286

[11] Available fromhttps://www. fantaproject.org/ [Accessed: 18 July 2019]

[12] Available from: https://www. fantaproject.org/focus-areas/maternaland-child-health-and-nutrition/ nutrition-situation-asia [Accessed: 18 July 2019]

[13] Andini R. Assessment of genetic diversity of nutritional values and agronomic traits in Indonesian amaranths. University of Tsukuba; 2013. 125 p. Available from: https://www.google. $\mathrm{com} /$ url? sa $=$ t $\&$ rct $=$ j\&q $=\&$ esrc $=$ s \&s ource $=$ web $\& c d=1 \&$ cad $=$ rja $\&$ uact $=8$ \&ved=2ahUKEwik-M6q-b7jAhWHu Y8KHalYCTAQFjAAegQIAxAC\&url =https $\% 3 \mathrm{~A} \% 2 \mathrm{~F} \% 2 \mathrm{Ftsukuba}$.repo.nii. ac.jp\%2F\%3Faction\%3Drepository_ action_common_download\%26item_ id\%3D31345\%26item_ no\%3D1\%26attribute_id\%3D17\%26file_ no\%3D1\&usg=AOvVaw34

OP8wj5oYG5X8ACQ0Vs6 [Accessed: 18 July 2019]

[14] Juan R, Pastor J, Alaiz M, Vioque J. Electrophoretic characterization of Amaranthus L. seed proteins and its systematic applications. Botanical Journal of the Linnean Society. 2007;155:57-63

[15] Joshi DC, Sood S, Hosahatti R, Kant L, Pattanayak A, Kumar A, et al. 
Theoretical and Applied Genetics. 2018. DOI: $10.1007 / \mathrm{s} 00122-018-3138-y$

[16] Jain SK, Hauptli H, Vaidya KR. Outcrossing rate in grain amaranths. The Journal of Heredity. 1982;73:71-72

[17] Andini R, Sulaiman MI, Ohsawa R, Natural Polyploidy in Amaranths (Amaranthus spp.). AIP Conference Proceedings. 2002. 020053 (2018); DOI: 10.1063/1.5050149. published online on 15 August 2018

[18] Andini R, Sulaiman MI, Moulana R, Ohsawa R. Application of principle component analysis in differentiating the three types of Amaranthus based on their photoperiodic flowering response. Oral presentation in the 1st International Conference of Agriculture and Bioindustry. Banda Aceh; 24-26 October 2019

[19] Gupta S, Lakshmi J, Manjunath MN, Prakash J. Analysis of nutrient and antinutrient content of underutilized green leafy vegetables. LWT. 2005. DOI: 10.1016/j.lwt.2004.06.012

[20] Shukla S, Bhargava A, Chatterjee A, Pandey AC, Mishra BK. Diversity in phenotypic and nutritional traits in vegetable amaranth (Amaranthus tricolor), a nutritionally underutilized crop. Journal of the Science of Food and Agriculture. 2010;90:139-144

[21] Kalinova J, Dadakova E. Rutin and total quercetin content in Amaranth (Amaranthus sp.). Plant Foods for Human Nutrition. 2009;64:68-74

[22] Andini R, Shigeki Y, Ohsawa R. Variation in protein content and amino acids in the leaves of grain, vegetable, and weedy types of Amaranths. Agronomy. 2013. DOI: 10.3390/ agronomy3020391

[23] Prakash D, Pal M. Nutritional and antinutritional composition of vegetable and grain amaranth leaves. Journal of the Science of Food and Agriculture. 1991;57:573-583

[24] Barba de la Rosa AP,

Fomsgaard IS, Laursen B, Mortensen AG, Olvera-Martínez L, Silva-Sánchez, et al. Amaranth (Amaranthus

hypochondriacus) as an alternative crop for sustainable food production: phenolic acids and flavonoids with potential impact on its nutraceutical quality. Journal of Cereal Science. 2018. DOI: 10.1007/s00122-018-3138-y

[25] Vélez-Jiménez E, Tenbergen K, Santiago PD, Cardador-Martinez MA. Functional attributes of amaranth. Austin Journal of Nutrition and Food Sciences. 2014;2(1):6

[26] Venskutonis PR, Kraujalis P. Nutritional components of amaranth seeds and vegetables: a review on composition, properties, and uses. Comprehensive Reviews in Food Science and Food Safety. 2013;12:381-412

[27] Sharma OP, Bhat TK. Analytical methods: DPPH antioxidant assay revisited. Food Chemistry. 2009;113:1202-1205

[28] Stintzing FC, Kammerer D, Schieber D, Adama H, Nacoulma OG, Carle R, Betacyanin and phenolic compounds from Amaranthus spinosus L. and Boerhavia errecta L. Verlag der Zeitschrift fuer Naturforschung, Tuebingen. 2004; 0939-5075/2004/0100-0001 


\title{
Chapter 6
}

\section{Functional Value of Amaranth as Applied to Sports Nutrition}

\author{
Torregrosa-García Antonio and López-Román F. Javier
}

\begin{abstract}
Amaranth can be beneficial to health and sports, with multiple applications owing to varied concentration of phytochemical; the concentration of these compounds depends on the part or by-product employed. For example, as a food supplement, amaranth oil (rich in squalene) can exert cardiovascular properties, while amaranth extract (rich in nitrites) can increase nitric oxide production (therefore improving endurance performance). On the other hand, as a functional ingredient, its gluten-free flours (containing fibre) can act as probiotics, whereas its proteins (with a peculiar amino acid profile) support muscle recovery. The few clinical results with athletic population suggest it can contribute to improved aerobic metabolism, but there is insufficient clinical data to draw any conclusion. Further research warrants elucidation of amaranth phytochemicals as promising ergogenic aids in sports by high-quality human clinical trials with both standardised products and ingredients in athletic population.
\end{abstract}

Keywords: amaranth, sports nutrition, clinical trial, functional food, athletic performance, recovery, ergogenic aid

\section{Introduction}

The field of sports nutrition studies how food and other dietary supplements can improve performance and general health status of physically active subjects, or athletes (both recreational and professional). Usually, recreational physical activity aims to obtain the healthy benefits which can include improved mood and movement in daily physical activities, aesthetic reasons and maintenance of health status. On the other hand, competitive athletes (especially elite athletes) pursue to peak performance.

For this reason, the first category of subjects would prefer including functional foods and change their overall diet by healthier choices (whatever definition is in their minds), while competitive subjects might prefer a combination of nutritional strategies with promising dietary supplements. Surveys vary much to this respect, but statistics estimated that between 40 and $100 \%$ of athletes typically uses supplements such as sports foods, medical supplements, ergogenic supplements and functional foods (super foods) [1,2]. Amaranth is a pseudo-cereal which has many edible parts like seeds and leaves and by-products (like amaranth oil, flour and powder) which has been attributed to many health benefits.

The area of sports nutrition studying all these aspects is an emerging field which shows some evidence showing efficacy for active compounds, while others still need further quality research to draw reliable initial conclusions. This chapter 
reviews the existing literature of amaranth applied to the sports field and discusses the potential application of amaranth and its derivate products to sports and their functional value supported by the existing clinical and empirical data.

\section{Existing literature of amaranth in the sports field}

The number of published research articles of amaranth with physically active human population is still scarce. The few studies found (through Google Scholar and PubMed search engines) at the time of writing this article are summarised in Table 1. Two of the three articles found employed amaranth oil, while the other employed a different product (amaranth drink instead of amaranth oil). To our best knowledge, only one of the studies assessed amaranth supplementation in an exercise test, while the other two studies used athletic population to measure aerobic metabolism parameters and cardiovascular parameters (heart rate variability). Furthermore, the only trial with an exercise test administered an amaranth drink, while most of the clinical literature addresses the functional properties of amaranth oil-without a single clinical trial with exercise tests in athletic population to our best knowledge. Due to the small amount of exercise test-related data, it is not feasible to obtain strong conclusions of the contribution of amaranth products to sports, according to various guidelines to assess the level of clinical evidence [3, 4].

\section{Prospective applications of functional value of amaranth to exercise}

There is a good rationale to employ amaranth in the sports field. The following chapter discusses the potential application of the functional value of amaranth and its by-products supported by the existing clinical and empirical data of previous studies.

\subsection{Amaranth sports performance and metabolism}

\subsubsection{Amaranth impact on aerobic metabolism}

Among amaranth products, the most studied by its functional properties is perhaps amaranth oil. Amaranth oil possesses large quantities of polyunsaturated fatty acids (PUFAs) especially linoleic acid (LA) (38.2\%) (the most important FA in the omega-6 family) and oleic acid (33.3\%) [5]. Action of PUFAs on heart rate variability was previously linked to omega-3 fatty acids (FAs) [6] translated in heart rate recovery after exercise partly attributed to incorporation in myocardial cells, affecting cardiovascular performance [7-9]. However, amaranth oil has a small quantity of alpha-linolenic acid (ALA) (compared to other seeds like walnuts and flaxseed oil [10] which are the one addressed to improve performance in sports [11]).

In spite of this fact, amaranth oil was studied in athletes showing activation of aerobic metabolism (important in long distances and low- to medium-intensity sports), concomitant with clinical biomarkers showing an improved utilisation of oxidation waste products (lipid peroxidation products), showing improved heart rate variability (HRV) [12], which is related with a better physical performance condition $[13,14]$. This happened also in another study also for the group patients with diabetes mellitus 2 [15] later confirmed by studies in unhealthy subjects (duodenal peptic ulcer patients) [16]. 


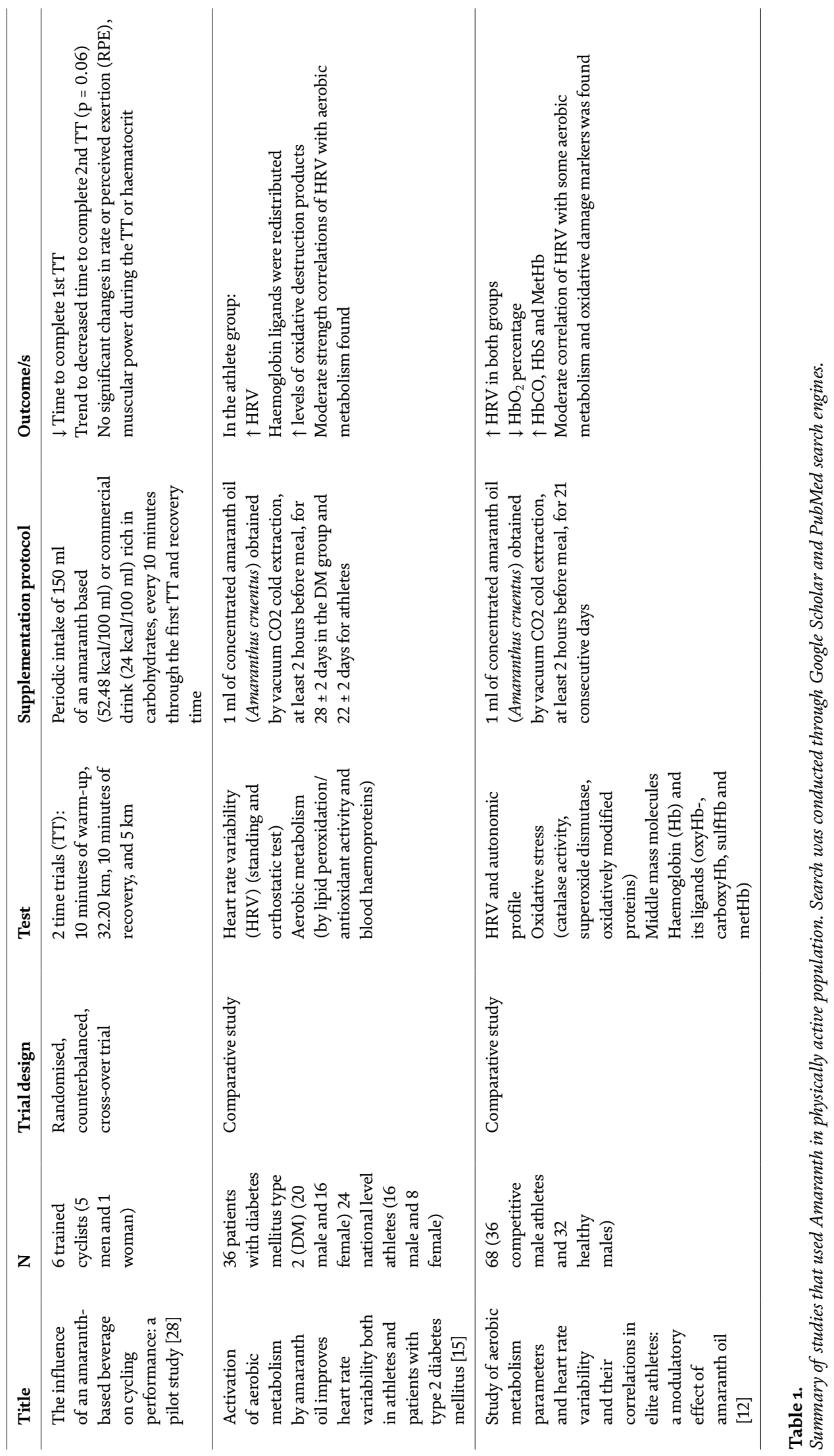


Another mechanism in which amaranth can contribute to aerobic performance is through participation in the nitric oxide pathway, thanks to its nitrate and nitrite composition. Dietary nitrate is firstly converted to nitrite by the oral microflora $[17,18]$ and then can enter into the system. A study with healthy human subjects supplemented with $2 \mathrm{~g}$ of amaranth extract showed a significant increase in plasma nitrate and nitrite, lasting up to 8 hours after administration [19].

Nitric oxide (NO) is important in physiological processes that may enhance exercise performance [20-22]. Some studies showed amaranth extract capacity to increase nitrite and nitrate in plasma, which is expected to increase the production of nitric oxide [19] (previously seen in cell cultures [23] and animal models [24]). Nitric oxide has been linked to improved endurance performance by reducing the oxygen cost during exercise, increasing the efficiency of energy production [25] (through an increase in mitochondrial efficiency [26] and ATP turnover functions [27]). Nitric oxide dietary supplements are widely consumed among athletes, and therefore future employment of amaranth extracts in new powder sports products (like pre-workouts) could be enticing if its efficacy is clinically validated.

\subsubsection{Amaranth and carbohydrate metabolism}

Amaranth components and ingredients can be used both as an ergogenic aid or a healthy food depending on the glycaemic index (GI) (the speed at which glucose appears in the bloodstream). High-glycaemic index foods have been attributed to higher conversion in triglycerides (fat) but may be of interest when, after a workout, our aim is to provide a fast source of carbohydrates to quickly restore muscle glucose stores (glycogen). Previous work stated that after exercise, a transitory physiological phenomenon called "metabolic window" (also referred as "anabolic window") occurs, so that utterly every carbohydrate (glucose) is synthesised to muscle glycogen and therefore stored the "healthy way" (not converted into fat).

A study with women showed that a snack with extruded amaranth presented a significantly higher GI (107) and insulinemic response than white bread, which can be recommended to athletes with this purpose as a post-workout snack [29]. amaranth starch has low viscosity and high solubility, greater than wheat and corn starches, with little content in resistant starch which provides a high glycaemic ingredient that can be dissolved in high concentrations in water, with high digestibility [30] which can be used efficiently in post-workout drinks to quickly restore glycogen stores. However, outside this metabolic window, the interest could be to avoid high GI foods, so they are not concomitantly synthesised as lipids, which can increase our fat stores (mainly as fat tissue under the skin).

Replacement of some traditional products with amaranth-based products can represent a healthier option, when they present a low GI, as in amaranth-based breakfast cereals. However, the format employed is the most determinant factor for its GI, showing higher values for a popped amaranth (105.2) than a regular cereal (74.1) but significantly lower for amaranth cereals (45.9) [31]. This is in line with a study with diabetic patients in which a diet with different amaranth proportions (grain, popped amaranth and amaranth-wheat flour) showed that its employment can represent a low or high GI [32]. This should be taken in consideration by athletes to decide when to use each product.

Apart from amaranth nutritional properties as an ingredient, amaranth oil can also improve carbohydrate metabolism as a food supplement. Previous studies with animal models showed that amaranth grain and oil can exert a hypoglycaemic effect in diabetic $[33,34]$ and in postmenopausal women $(n=90)$ when administered with amaranth leaf powder [35], showing a decreased fasting blood glucose level. 
However, further research is needed to clarify its role in athletic population and if these clinical markers are translated in improvement of physical and/or biochemical markers and health condition.

\subsection{Recovery and health maintenance of the athlete}

\subsubsection{Cardiovascular system health}

The main benefit associated with amaranth in cardiovascular health is through amaranth oil (very likely its high squalene content). Squalene is an unsaturated hydrocarbon ranging from 2.4 to $8.0 \%[36,37]$, which has a similar structure to beta-carotene, and is an intermediate metabolite in the synthesis of cholesterol [38].

Animal models showed a decrease in total level of cholesterol by amaranth grain $[39,40]$ and also of triglycerides, LDL cholesterol [41] and VLDL [33] in addition to the fatty acid composition of the membranes of erythrocytes by amaranth oil [42] later confirmed in human patients after taking $600 \mathrm{mg}$ of squalene [43]. This was also found in a study with a larger number of patients $(n=125)$ with amaranth oil intake from 3 to $18 \mathrm{ml}$ daily ( $3 \mathrm{ml}$ provides $100 \mathrm{mg}$ of squalene) for 3 weeks, showing a dose-dependent relation with also reduced systolic and diastolic blood pressure [44].

In addition to its oil, other bioactive peptides have been found in amaranth with interesting applications to cardiovascular health. For example, globulin $11 \mathrm{~S}$ [45] showed a potential to modulate the angiotensin system [through inhibition of angiotensin-I-converting enzyme (ACE)] tested to be resistant to gastrointestinal hydrolysis in a simulated digestive environment [46], suggesting resistance to peptic hydrolysis by human digestion. Seed protein hydrolysates also showed antihypertensive effect in vivo [47], which was also the case for amaranth oil in pulmonary arterial hypertension, although a lot of clarification is required to this respect [48]. Other in vitro studies showed that the pure peptides of amaranth inhibit cellular markers associated with the development of atherosclerosis [49] (a disease strongly linked to coronary artery disease [50]).

Apart from its regular edible parts, amaranth leaf powder also showed a different action to cardiovascular markers by increasing haemoglobin levels after administration of $9 \mathrm{~g}$ daily (for 3 months) in postmenopausal women [35], in line with the effect of amaranth oil, which showed a shift in haemoglobin ligands in athletes [15]. A combination of amaranth edible parts (seeds, oils and flours) as part of the diet, combined with supplements of its bioactive compounds (as per its leaves and peptides), seems to be linked to the cardiovascular physiology to some extent.

The cardiovascular system is also comprised of the blood vessels, whose inner tissue (endothelium) health status is a determinant and plays an important factor in the energetic chain, due to its role in the interchange of nutrients and oxygen. To this respect, NO is an important signalling molecule that can improve endothelial function and, as previously discussed, can be enhanced by the dietary intake of nitrite present in amaranth extracts [19]. It should be noted that NO is usually produced during exercise in absence of dietary supplementation [51] and that improvements in endothelial function are not only dependent on the cells of the arteries but also by the bone marrow whose main stimulator is also the NO produced by exercising [52]. However, the growth factor which is important during the first stages of training adaptation becomes significantly reduced after significant angiogenesis has occurred [53], and therefore, external sources (like in amaranth extracts) that can improve the endothelial function are of high value to preserve its health integrity. 


\subsubsection{Amaranth fibre as a probiotic for health and athletic performance}

Probiotics and gut microbiota health are becoming popular among athletes and general population. Intense and strenuous exercise can impact gastrointestinal health status [54], while on the other hand, recent publications suggest that probiotics and gut microbiota are related to improved exercise performance [55]. Probiotics are an early field of study in sports nutrition, which can directly interact with gut microbiota and interact with the mucosal immune system and immune signalling to a variety of organs and systems [56].

Dietary fibre can serve as food for the microbiota, and to this respect, amaranth is a good source. Fibre from amaranth seeds is $78 \%$ insoluble (mainly composed of pectic substances: galacturonic acid, arabinose, galactose, xylose and glucose) and $22 \%$ soluble (mainly xyloglucans and arabinose-rich pectic polysaccharides) [57].

While clinical studies in humans are still missing to prove the effects of amaranth fibre to human microbiota, an in vitro study (emulating human intestinal ecosystems) suggests it has a probiotic effect, as it exerts some properties to specific culture of probiotic cultures [58], and a prebiotic effect (by increasing Bifidobacterium spp. and Lactobacillus/Enterococcus) as confirmed in human faeces [59] (and in vitro [60]). Apart from possible influence of amaranth fibre to microbiota, the fibre content can help to relieve common gut problems derived from the disturbance of mucosal surfaces because of prolonged or intensive exercise [61], which can be a beneficial side effect.

In addition, amaranth protein is surprisingly a source of dietary fibre with prospective applications to sports nutrition, since protein concentrate powders are widely used among athletes in protein shakes, being the main product consumed by muscle builders. The soluble dietary fibre content or amaranth protein concentrate powder is notably higher $[12.90 \mathrm{~g} / 100 \mathrm{~g}$ on dry weight $(\mathrm{dw})]$ than in its flour $(4.29 \mathrm{~g} / 100 \mathrm{~g} \mathrm{dw})$ also with higher content of insoluble fibre (20.69 g/100 g dw against $5.54 \mathrm{~g} / 100 \mathrm{~g}$ ) [62]. This kind of amaranth product would provide large amounts of fibre for the development of gut microbiota, being also a source of vegetable protein. Clinical studies with protein and probiotics (whey + probiotics) showed improved recovery (diminished exerciseinduced muscle damage) in recreationally trained males [63], as well as an improved strength restoration [64], compared to only protein (whey: probably the most widely used protein powder). Further research should be carried to study if this behaviour is mimicked when vegetal proteins (like amaranth's) are used, compared to that of milk (whey).

\subsubsection{Antioxidant effect linked to sports}

Polyphenols (the most abundant antioxidants in plants) have shown to improve athletic performance from large improvement to moderate impairment [65], while a meta-analysis showed an average improvement of $1.90 \%$ (95\% CI $0.40-3.39$ ) when at least supplemented by 7 days. They also have been blamed to impair training adaptations due to its antioxidative effects by chronic supplementation [66-68] which may hamper the development of antioxidant endogenous enzymes, while a recent review states that acute administration just before or during exercise can have beneficial effects [69]. Different parts of amaranth contain fractions of a variety of antioxidants which could be employed.

Amaranth sprouts are rich in red-coloured betacyanins-a subclass pigment belonging to the betalain family (and therefore a polyphenol) - with known antioxidant [68] and anti-inflammatory properties [70] in vitro [35], which at the same time can be applied to improve performance in sports. Betacyanins are also present 
in other red-coloured plants like beet $[71,72]$ still requiring studies in humans to clarify its bioavailability, which suggests being low [73].

In addition, amaranth seeds and sprouts showed antioxidant flavonoids (such as rutin) and phenolics (like gallic acid, $p$-hydroxybenzoic acid and vanillic acid), while sprouting makes the appearance of $p$-coumaric and syringic acid (related with light exposure) [74].

Clinical studies showed that supplementation with amaranth leaf powder in postmenopausal women showed a significant increase in the endogenous antioxidant enzymes superoxide dismutase and glutathione peroxidase with decrease in the marker of oxidative stress malondialdehyde [35]. These are developed as a consequence of oxidation provoked by training in physical exercise, but more research is required to assess any possible contribution of the described antioxidants of amaranth ingredients to trained athletes (which presumably have developed this endogenous antioxidant system to its highest) and its link to sports performance outcomes.

\subsubsection{Amaranth protein, muscle recovery and improved body composition}

Early studies suggested that amino acid composition of amaranth grain protein had leucine as the limiting amino acid [75] (later confirmed in post-prandial analysis of children [76]), while it is pretty rich in lysine [62] and tryptophan [76] being suitable to combine with other cereals and provide a more balanced amino acid profile [77]. On the other hand, latter studies suggest that they are especially rich in the essential amino acids threonine and tryptophan [78] and that leucine and lysine are not the limiting amino acids in pseudo-cereals [79] (contrary to cereals) which are not true cereals from a botanical view and have nutritionally been considered as a mix of rice and beans. Protein in amaranth seeds is mainly in the embryo (instead of the endosperm) [80] showing also variation in their composition between species [81, 82]. Proteins have been appointed as the macronutrient with the most satiating effect [83] which can cause an improvement in body composition thanks to an increased satiety [84].

Protein powders which are popular among athletes can also include diverse forms like concentrates (the most common and cheap) or isolates (with virtually no carbohydrate fraction) and additionally be hydrolysed (with its proteins partly broken into smaller peptides and even amino acids). Protein hydrolysates of whey have shown to increase the insulin concentration due to a mechanism independent of gastric emptying, which can improve muscle repair by its accentuated anabolic response. Amaranth protein hydrolysate releases biopeptides which were investigated for its antihypertensive properties [47]. Studies in humans warrant further research in this field to study the same response in insulin of blood pressure in healthy and physically active population.

\subsubsection{Employment of amaranth for gluten-free diets and vegan diets}

Nutritional strategies through special diets are a common resource used by athletes to reduce fat mass, increase muscle mass and improve health [85]. Among these diets we find raw food diets, gluten-free diets and vegan diets [86].

To this respect, amaranth is a gluten-free alternative source of carbohydrates which can be used in gluten-free diets [87]. Amaranth can be cooked in water, extruded (appearance is of pellet form, which could be used as breakfast cereals (for a picture see [88])), toasted, incorporated into flakes $[89,90]$ or pastas and baked into bread, biscuits and cookies, resulting in gluten-free bakery foodstuffs [91]. Some work has been done to try to develop grain amaranth-based 
nutrient-rich snack bars [92]. In Mexico, Amaranth cruentus cultivars are used to manufacture cookies called "Alegria" [93] (in which amaranth is used in the form of popcorn) and a commercial drink called "atole" made from milled and roasted amaranth seed, which contains large amounts of sugar. In Asia, the Indian diet find amaranth grain as an alternative to wheat, easy to incorporate into the traditional cuisine [94].

On the other hand, amaranth protein is suitable for vegan diets of athletes, whose requirement in protein can be markedly high $[86,95]$ and whose nutritional value was previously discussed (see 3.2.4 Amaranth protein, muscle recovery and improved body composition).

\section{Further research in the sports field of amaranth}

\subsection{Clinical trials with amaranth and athletic population require more research}

Nutraceuticals are an area of recent research in which substances not traditionally associated with nutrients or drugs show physiological effect on the body [96]. The nutraceutical era is an emerging opportunity to find the inherent nutritional value in biology (like the functional value of amaranth discussed in this book) and requires an additional effort in its research to conduct robust and controlled clinical trials to throw light on the knowledge field. Compared to the research conducted in pharmacy, nutrition, nutraceuticals and dietary supplements in the sports nutrition field require clinical studies with good trial design and standardised products and ingredients. Uncontrolled factors, as the regular diet of subjects participating in a clinical trial, can contain one or different functional molecules that can affect the results of the trial, so its study as stand-alone substances is not so easy (and in fact is better controlled in clinical trials with patients staying in a hospital room). The following section focuses on some of the aspects that should be taken in consideration to conduct further high-quality research with amaranth.

\subsection{Fluctuation in the nutritional value of amaranth plants should be considered}

Natural ingredients and by-products from plants are subject to a natural fluctuation in their composition and nutritional value (which can affect their functional effect) due to external factors or conversions until they are manufactured a final ingredient or product. These are some of the empirical data found in the literature when assessing the functional value of amaranth products used in clinical trials:

\subsubsection{External factors during crop growth}

External factors during the growth of the crop, its manufacturing and conversion until a final product is created can affect the nutritional value of amaranth:

- The lipidic content (which includes squalene) shows great variations depending on the species and genotype $[37,97]$ as well as the different parts of the seed [98].

- Stress and other external crop factors can influence their nutritional value [99] and in consequence its clinical outcomes. 
- Enrichment with selenium of Amaranthus cruentus improved its anti-inflammatory effect in rat models, very likely due to its increased content in betacyanins and selenium which significantly decreased inflammatory interleukin 6 production [100].

- Sunlight exposure of Amaranthus tricolor showed more development of redfleshed cultivars with greater exposure to direct sunlight, with an increased quantity of antioxidants like polyphenols [101].

- Stress like climate changes and harsh conditions can affect seed's morphology and nutritional value, which showed globulins paralogs and precursors in wild species, which could be a genetic source for improving the nutritional quality of amaranth seed [102].

- Amaranth sprouting showed increased vitamin content (significantly in biotin, folic acid and especially riboflavin (vitamin B2) and ascorbic acid (vitamin C) [103]) and decreased lipid and phytic acid content, which also is specie dependent [104].

- Amaranth contains varying amounts of vitamin $\mathrm{C}$ depending on the species and part used, with around 69-288 mg/100 $\mathrm{g}$ in the grains and 62-209 mg/100 g [105], which is suggested to have an important role in the defence of exercise-induced oxidative stress [106].

\subsubsection{Manufacturing and storage can also affect its nutritional and functional values}

Manufacturing of amaranth to final product is also an important stage in the consecution of a dietary supplement for administration in clinical trials. Amaranth oil is extracted by squeezing amaranth grain, which can be extracted by cold extraction (considered as a gold standard in the manufacture of virgin oils) —which should be a well-controlled process to assure integrity maintenance of the oil-or solvent extraction (which requires further purification). On the other hand, amaranth flours can be converted to breakfast cereals by puffing or extruded, both processes that can affect its integrity, which is also affected by heat if, for example, used in bakery.

These are some of the facts found in literature which found how extraction technologies can affect amaranth bioactives and their functionality:

- Processing of amaranth may result in losses in protein content [107] as later confirmed by a study which abolished the sensitization potential of albumins with hypoallergenic properties in rats [108].

- Heating can affect antioxidant capacity [109], and phytic acid content has shown to be significantly decreased after undergoing a low-cost extrusion process.

- Storage conditions, as shown in a study which stored amaranth leaves, showed a reduction in beta-carotene of up to $85.0 \%$ [110] and a decrease in lysine of 4.8 and $9.6 \%$ in cracker and biscuits, respectively, after 4 months of storage [111].

- Extrusion improved anti-inflammatory effect of bioactive peptide hydrolysates studied afterwards in rat models [112], while other studies state 
that antioxidant capacity (phenolic content) decreased on the favour of an improved digestibility (tested in vivo) [113].

- Puffing to convert amaranth seeds into popped amaranth (breakfast cereallike product) — probably the most popular breakfast amaranth product [114] — can influence its nutritive value by decreasing the unsaturation of PUFAs, mainly linoleic acid (from 46.8 to $27.0 \%$ ) with increased squalenes (by $15.5 \%$ ) [115].

- In children, post-prandial amino acid analysis after the intake of toasted, popped or flaked amaranth consumption caused significant falls in leucine and threonine, suggesting that these were first- and second-limiting essential amino acids [76].

\subsection{Standardised amaranth ingredients}

Natural fluctuation is difficult to control, but there is an alternative solution to control the active ingredients in a dietary ingredient or supplement: Standardisation

Standardisation consists with describing a set of technical standards to guarantee constant qualitative and quantitative parameters and therefore its safety, quality and efficacy [116]. According to the same authors, these are some of the problems associated with nutraceuticals (not happening in synthetic drugs):

1. They are a mixture of many constituents.

2. The active ingredient/s is/are in some cases unknown.

3. Selective analytical methods or reference compounds (standard samples) may not be commercially available.

4. Plant materials are chemically and naturally variable.

5. Chemo-varieties and cultivars exist.

6. The source and quality of the raw material are variable.

Therefore, further research should focus on proper analysis of the composition of the product used for the trials, and pursue to guarantee, that the target compound is found in enough amounts, and not other compounds which might affect the outcomes of its experiments. Application of manufacturing processes to isolate active compounds like squalenes (by fractionation and distillation), as shown in a study [117], may allow the isolation of them for its further clinical study.

\section{Conclusions}

1. Amaranth still requires further investigation in athletes and physically active healthy subjects to study its functional effect on sports performance. The few results suggest it can activate the aerobic metabolism.

2. Clinical results with human and animal population and in vitro assays suggest physiological mechanisms that can contribute to aerobic performance through 
activation of NO pathways, as a source of high and low glycaemic index carbohydrate, possible activation of gut flora (probiotic) which can be translated to athletic performance, antioxidant effect and employment of its protein and/or biopeptides.

3. Maintenance of athlete's health can be obtained through amaranth properties on cardiovascular health, as a probiotic for gut microbiota, as a source of dietary antioxidants and as a suitable ingredient for special diets like glutenfree diets (of its flours) and vegan diets (as a vegetal protein).

4. Further research should consider amaranth natural fluctuation of its nutritive value by external factors and control its composition by thorough analysis or employment of standardised products and supplements.

\section{Author details}

Torregrosa-García Antonio* and López-Román F. Javier

San Antonio Catholic University of Murcia (UCAM), Murcia, Spain

*Address all correspondence to: atorregrosa@ucam.edu

\section{IntechOpen}

(C) 2019 The Author(s). Licensee IntechOpen. This chapter is distributed under the terms of the Creative Commons Attribution License (http://creativecommons.org/licenses/ by/3.0), which permits unrestricted use, distribution, and reproduction in any medium, provided the original work is properly cited. (cc) BY 


\section{References}

[1] Garthe I, Maughan RJ. Athletes and Supplements: Prevalence and Perspectives. International Journal of Sport Nutrition and Exercise Metabolism. 2018;28(2):126-138

[2] Jovanov P, Đorđić V, Obradović B, Barak O, Pezo L, Marić A, et al. Prevalence, knowledge and attitudes towards using sports supplements among young athletes. Journal of the International Society of Sports Nutrition. 2019;16(1):27

[3] Kerksick CM, Wilborn CD, Roberts MD, Smith-Ryan A, Kleiner SM, Jäger R, et al. ISSN exercise \& sports nutrition review update: Research \& recommendations. Journal of the International Society of Sports Nutrition. 2018;15(1):38

[4] Kreider RB, Wilborn CD, Taylor L, Campbell B, Almada AL, Collins R, et al. ISSN exercise \& sport nutrition review: research \& recommendations. Journal of the international society of sports nutrition. Dec 2010;7(1):7

[5] León-Camacho M, García-González DL, Aparicio R. A detailed and comprehensive study of amaranth (Amaranthus cruentus L.) oil fatty profile. European Food Research and Technology. 2001;213(4-5):349-355

[6] Christensen JH, Christensen MS, Dyerberg J, Schmidt EB. Heart rate variability and fatty acid content of blood cell membranes: A dose-response study with $n-3$ fatty acids. The American Journal of Clinical Nutrition. 1999;70(3):331-337

[7] Macartney MJ, Hingley L, Brown MA, Peoples GE, McLennan PL. Intrinsic heart rate recovery after dynamic exercise is improved with an increased omega-3 index in healthy males. The British Journal of Nutrition. 2014;112(12):1984-1992
[8] O’Keefe JH, Abuissa H, Sastre A, Steinhaus DM, Harris WS. Effects of omega-3 fatty acids on resting heart rate, heart rate recovery after exercise, and heart rate variability in men with healed myocardial infarctions and depressed ejection fractions. The American Journal of Cardiology. 2006;97(8):1127-1130

[9] Salvatore P, McLennan Peter L. Cardiac membrane fatty acid composition modulates myocardial oxygen consumption and postischemic recovery of contractile function. Circulation. 2002;105(19):2303-2308

[10] DeFilippis AP, Sperling LS. Understanding omega-3's. American Heart Journal. 2006;151(3):564-570

[11] Gammone MA, Riccioni G, Parrinello G, D’Orazio N. Omega-3 polyunsaturated fatty acids: Benefits and endpoints in sport. Nutrients. 2019;11(1):46

[12] Yelisyeyeva O, Cherkas A, Semen K, Kaminskyy D, Lutsyk A. Study of aerobic metabolism parameters and heart rate variability and their correlations in elite athletes: A modulatory effect of amaranth oil. Clinical and Experimental Medical Journal. 2009;3(2):293-307

[13] Aubert AE, Seps B, Beckers F. Heart rate variability in athletes. Sports Medicine. 2003;33(12):889-919

[14] De Meersman RE. Heart rate variability and aerobic fitness. American Heart Journal. 1993;125(3):726-731

[15] Yelisyeyeva O, Semen K, Zarkovic N, Kaminskyy D, Lutsyk O, Rybalchenko V. Activation of aerobic metabolism by Amaranth oil improves heart rate variability both in athletes and patients with type 2 diabetes mellitus. Archives of Physiology and Biochemistry. 2012;118(2):47-57 
[16] Cherkas A, Zarkovic K, Cipak Gasparovic A, Jaganjac M, Milkovic L, Abrahamovych O, et al. Amaranth oil reducesaccumulationof4-hydroxynonenalhistidine adducts in gastric mucosa and improves heart rate variability in duodenal peptic ulcer patients undergoing Helicobacter pylori eradication. Free Radical Research. 2018;52(2):135-149

[17] Spiegelhalder B, Eisenbrand G, Preussmann R. Influence of dietary nitrate on nitrite content of human saliva: Possible relevance to in vivo formation of N-nitroso compounds. Food and Cosmetics Toxicology. 1976;14(6):545-548

[18] Tannenbaum SR, Weisman M, Fett D. The effect of nitrate intake on nitrite formation in human saliva. Food and Cosmetics Toxicology. 1976;14(6):549-552

[19] Subramanian D, Gupta S. Pharmacokinetic study of amaranth extract in healthy humans: A randomized trial. Nutrition. 2016;32(7):748-753

[20] Jones AM. Dietary nitrate supplementation and exercise performance. Sports Medicine. 2014;44(1):35-45

[21] Habib S, Ali A. Role of nitric oxide in sports nutrition. In Nutrition and Enhanced Sports Performance. Academic Press; 1 Jan 2019. pp. 317-325. Available from: http:// www.sciencedirect.com/science/article/ pii/B9780128139226000278

[22] Bloomer RJ. Nitric oxide supplements for sports. Strength \& Conditioning Journal. 2010;32(2):14

[23] Barba de la Rosa AP, Barba Montoya A, Martínez-Cuevas P, Hernández-Ledesma B, León-GalvánMF, De León-Rodríguez A, et al. Tryptic amaranth glutelin digests induce endothelial nitric oxide production through inhibition of ACE: Antihypertensive role of amaranth peptides. Nitric Oxide. 2010;23(2):106-111

[24] Caselato-Sousa VM, Ozaki MR, de Almeida EA, Amaya-Farfan J. Intake of heat-expanded amaranth grain reverses endothelial dysfunction in hypercholesterolemic rabbits. Food \& Function. 2014;5(12):3281-3286

[25] Besco R, Sureda A, Tur JA, Pons A. The effect of nitric-oxide-related supplements on human performance. Sports Medicine. 2012;42(2):99-117

[26] Larsen FJ, Schiffer TA, Borniquel S, Sahlin K, Ekblom B, Lundberg JO, et al. Dietary inorganic nitrate improves mitochondrial efficiency in humans. Cell Metabolism. 2011;13(2):149-159

[27] Bailey SJ, Fulford J, Vanhatalo A, Winyard PG, Blackwell JR, DiMenna FJ, et al. Dietary nitrate supplementation enhances muscle contractile efficiency during knee-extensor exercise in humans. Journal of Applied Physiology. 2010;109(1):135-148

[28] Espino-González E, Muñoz-Daw MJ, Rivera-Sosa JM, la Torre-Díaz MLD, Cano-Olivas GE, Lara-Gallegos JCD, et al. THE influence of an amaranthbased beverage on cycling performance: A pilot study. Biotecnia. 2018;20(2): 31-36

[29] Guerra-Matias AC, Arêas JAG. Glycemic and insulinemic responses in women consuming extruded amaranth (Amaranthus cruentus L). Nutrition Research. 2005;25(9):815-822

[30] Capriles VD, Coelho KD, Guerra-Matias AC, Arêas JAG. Effects of processing methods on amaranth starch digestibility and predicted glycemic index. Journal of Food Science. 2008;73(7):H160-H164

[31] Schneider I, Heinemann M, Hahn A. Comparison of glycemic index and 
satiety of cereals containing amaranth. Journal of Human Nutrition \& Food Science. 2015;3(5):1074

[32] Chaturvedi A, Sarojini G, Nirmala G, Nirmalamma N, Satyanarayana D. Glycemic index of grain amaranth, wheat and rice in NIDDM subjects. Plant Food for Human Nutrition. 1997;50(2):171-178

[33] Kim HK, Kim M-J, Shin

D-H. Improvement of lipid profile by amaranth (Amaranthus esculantus) supplementation in streptozotocininduced diabetic rats. Annals of Nutrition and Metabolism. 2006;50(3):277-281

[34] Kim HK, Kim MJ, Cho HY, Kim E-K, Shin DH. Antioxidative and anti-diabetic effects of amaranth (Amaranthus esculantus) in streptozotocin-induced diabetic rats. Cell Biochemistry and Function. 2006;24(3):195-199

[35] Kushwaha S, Chawla P, Kochhar A. Effect of supplementation of drumstick (Moringa oleifera) and amaranth (Amaranthus tricolor) leaves powder on antioxidant profile and oxidative status among postmenopausal women. Journal of Food Science and Technology. 2014;51(11):3464-3469

[36] Bruni R, Medici A, Guerrini A, Scalia S, Poli F, Muzzoli M, et al. Wild Amaranthus caudatus seed oil, a nutraceutical resource from Ecuadorian flora. Journal of Agricultural and Food Chemistry. 2001;49(11):5455-5460

[37] Rodas B, Bressani R. The oil, fatty acid and squalene content of varieties of raw and processed amaranth grain. Archivos Latinoamericanos de Nutrición. 2009;59(1):82-87

[38] Kelly GS. Squalene and its potential clinical uses. Alternative Medicine Review. 1999;4(1):29-36
[39] Shin DH, Heo HJ, Lee YJ, Kim HK. Amaranth squalene reduces serum and liver lipid levels in rats fed a cholesterol diet. British Journal of Biomedical Science. 2004;61(1):11-14

[40] Berger A, Gremaud G, Baumgartner M, Rein D, Monnard I, Kratky E, et al. Cholesterol-lowering properties of amaranth grain and oil in hamsters. International Journal for Vitamin and Nutrition Research. 2003;73(1):39-47

[41] Qureshi AA, Lehmann JW, Peterson DM. Amaranth and its oil inhibit cholesterol biosynthesis in 6-week-old female chickens. Journal of Nutrition. 1996;126(8):1972-1978

[42] Kulakova SN, Pozdniakov AL, Korf II, Karagodina ZV, Medvedev FA, Viktorova EV, et al. Amaranths oil: Peculiarities of chemical composition and influence on lipid metabolism by rats. Voprosy Pitaniia. 2006;75(3):36-42

[43] Gonor KV, Pogozheva AV, Kulakova SN, Medvedev FA, Miroshnichenko LA. The influence of diet with including amaranth oil on lipid metabolism in patients with ischemic heart disease and hyperlipoproteidemia. Voprosy Pitaniia. 2006;75(3):17-21

[44] Martirosyan DM, Miroshnichenko LA, Kulakova SN, Pogojeva AV, Zoloedov VI. Amaranth oil application for coronary heart disease and hypertension. Lipids in Health and Disease. 2007;6:1

[45] Silva-Sánchez C, de la Rosa APB, León-Galván MF, de Lumen BO, de León-Rodríguez A, de Mejía EG. Bioactive peptides in amaranth (Amaranthus hypochondriacus) seed. Journal of Agricultural and Food Chemistry. 2008;56(4):1233-1240

[46] Tiengo A, Faria M, Netto FM. Characterization and ACE-inhibitory 
activity of amaranth proteins. Journal of Food Science. 2009;74(5):H121-H126

[47] Fritz M, Vecchi B, Rinaldi G, Añón MC. Amaranth seed protein hydrolysates have in vivo and in vitro antihypertensive activity. Food Chemistry. 2011;126(3):878-884

[48] Yelisyeyeva O, Semen K, Bielawska K, Biernacki M, Kaminskyy D, Yavorskyi O, etal.Amaranthoilinprevalentpulmonary arterial hypertension: Changes in fatty acid panel and products of lipid peroxidation. Free Radical Biology \& Medicine. 2018;124:576-577

[49] Montoya-Rodríguez A, de Mejía EG. Pure peptides from amaranth (Amaranthus hypochondriacus) proteins inhibit LOX-1 receptor and cellular markers associated with atherosclerosis development in vitro. Foodservice Research International. 2015;77:204-214

[50] Hansson GK. Inflammation, atherosclerosis, and coronary artery disease. The New England Journal of Medicine. 2005;352(16):1685-1695

[51] Maiorana A, O’Driscoll G, Taylor R, Green D. Exercise and the nitric oxide vasodilator system. Sports Medicine. 2003;33(14):1013-1035

[52] Haram PM. Adaptation of endothelium to exercise training: Insights from experimental studies. Frontiers in Bioscience. 2008;13(13):336

[53] Richardson RS, Wagner H, Mudaliar SRD, Saucedo E, Henry R, Wagner PD. Exercise adaptation attenuates VEGF gene expression in human skeletal muscle. American Journal of Physiology. Heart and Circulatory Physiology. 2000;279(2):H772-H778

[54] Peters HPF, Vries WRD, VanbergeHenegouwen GP, Akkermans LMA. Potential benefits and hazards of physical activity and exercise on the gastrointestinal tract. Gut. 2001;48(3):435-439

[55] Pane M, Amoruso A, Deidda F, Graziano T, Allesina S, Mogna L. Gut microbiota, probiotics, and sport: From clinical evidence to agonistic performance. Journal of Clinical Gastroenterology. 2018;52:S46

[56] Pyne DB, West NP, Cox AJ, Cripps AW. Probiotics supplementation for athletes-Clinical and physiological effects. European Journal of Sport Science. 2015;15(1):63-72

[57] LamotheLM,SrichuwongS, ReuhsBL, Hamaker BR. Quinoa (Chenopodium quinoa W.) and amaranth (Amaranthus caudatus $\mathrm{L}$.) provide dietary fibres high in pectic substances and xyloglucans. Food Chemistry. 2015;167:490-496

[58] de Albuquerque MAC, Bedani R, Vieira ADS, LeBlanc JG, Saad SMI. Supplementation with fruit and okara soybean by-products and amaranth flour increases the folate production by starter and probiotic cultures. International Journal of Food Microbiology. 2016;236:26-32

[59] Gullón B, Gullón P, Tavaria FK, Yáñez R. Assessment of the prebiotic effect of quinoa and amaranth in the human intestinal ecosystem. Food \& Function. 2016;7(9):3782-3788

[60] Vieira ADS, Bedani R, Albuquerque MAC, Biscola V, Saad SMI. The impact of fruit and soybean by-products and amaranth on the growth of probiotic and starter microorganisms. Foodservice Research International. 2017;97:356-363

[61] de Oliveira EP, Burini RC. Fooddependent, exercise-induced gastrointestinal distress. Journal of the International Society of Sports Nutrition. 2011;8(1):12 
[62] Escudero NL, de Arellano ML, Luco JM, Giménez MS, Mucciarelli SI. Comparison of the chemical composition and nutritional value of Amaranthus cruentus flour and its protein concentrate. Plant Foods for Human Nutrition. 2004;59(1):15-21

[63] Jäger R, Shields KA, Lowery RP, Souza EOD, Partl JM, Hollmer C, et al. Probiotic Bacillus coagulans GBI-30, 6086 reduces exercise-induced muscle damage and increases recovery. PeerJ. 2016;4:e2276

[64] Jäger R, Purpura M, Stone JD, TurnerSM, Anzalone AJ, Eimerbrink MJ, et al. Probiotic Streptococcus thermophilus FP4 and Bifidobacterium breve BR03 supplementation attenuates performance and range-of-motion decrements following muscle damaging exercise. Nutrients. 2016;8(10):642

[65] Braakhuis AJ, Hopkins WG. Impact of dietary antioxidants on sport performance: A review. Sports Medicine. 2015;45(7):939-955

[66] Draeger C, Naves A, Marques N, Baptistella A, Carnauba R, Paschoal V, et al. Controversies of antioxidant vitamins supplementation in exercise: Ergogenic or ergolytic effects in humans? Journal of the International Society of Sports Nutrition. 2014;11(1):4

[67] Gomez-Cabrera MC, Ristow M, Viña J. Antioxidant supplements in exercise: Worse than useless? American Journal of Physiology. Endocrinology and Metabolism. 2012;302(4):E476-E477

[68] Gomez-Cabrera MC, Salvador-Pascual A, Cabo H, Ferrando B, Viña J. Redox modulation of mitochondriogenesis in exercise. Does antioxidant supplementation blunt the benefits of exercise training? Free Radical Biology \& Medicine. 2015;86:37-46
[69] Pastor R, Tur JA. Antioxidant supplementation and adaptive response to training: A systematic review. Current Pharmaceutical Design. 2019;25(16):1889-1912. ISSN: 13816128/1873-4286. Available from: http:// europepmc.org/abstract/med/31267859

[70] Kanner J, Harel S, Granit R. Betalains A new class of dietary cationized antioxidants. Journal of Agricultural and Food Chemistry. 2001;49(11):5178-5185

[71] Escribano J, Pedreño MA, García-Carmona F, Muñoz R. Characterization of the antiradical activity of betalains from Beta vulgaris L. roots. Phytochemical Analysis. 1998;9(3):124-127

[72] Pedreño MA, Escribano J. Studying the oxidation and the antiradical activity of betalain from beetroot. Journal of Biological Education. 2000;35(1):49-51

[73] Frank T, Stintzing FC, Carle R, Bitsch I, Quaas D, Straß G, et al. Urinary pharmacokinetics of betalains following consumption of red beet juice in healthy humans. Pharmacological Research.

2005;52(4):290-297

[74] Paśko P, Sajewicz M, Gorinstein S, Zachwieja Z. Analysis of selected phenolic acids and flavonoids in Amaranthus cruentus and Chenopodium quinoa seeds and sprouts by HPLC. Acta Chromatographica. 2008;20(4):661-672

[75] Becker R, Wheeler EL, Lorenz K, Stafford AE, Grosjean OK, Betschart AA, et al. A compositional study of amaranth grain. Journal of Food Science. 1981;46(4):1175-1180

[76] Graham GG, Lembcke J, Morales E. Post-prandial plasma aminograms in the assessment of protein quality for young children: Maize and grain amaranth, alone and combined. European Journal of Clinical Nutrition. 1990;44(1):35-43 
[77] Pedersen B, Kalinowski LS, Eggum BO. The nutritive value of amaranth grain (Amaranthus caudatus). Plant Food for Human Nutrition. 1987;36(4):309-324

[78] Nimbalkar MS, Pai SR, Pawar NV, Oulkar D, Dixit GB. Free amino acid profiling in grain amaranth using LC-MS/MS. Food Chemistry. 2012;134(4):2565-2569

[79] Mota C, Santos M, Mauro R, Samman N, Matos AS, Torres D, et al. Protein content and amino acids profile of pseudocereals. Food Chemistry. 2016;193:55-61

[80] Bressani R. The proteins of grain amaranth. Food Reviews International. 1989;5(1):13-38

[81] Juan R, Pastor J, Alaiz M, Megías C, Vioque J. Seed protein characterisation of eleven species of Amaranthus. Grasas y Aceites. 2007;58(1):49-55

[82] Pisarikova B, Kracmar S, Herzig I. Amino acid contents and biological value of protein in various amaranth species. Czech Journal of Animal Science. 2005;50:169-174. Available from: http://agris.fao.org/agris-search/ search.do?recordID $=$ CZ2005000610

[83] Morell P, Fiszman S. Revisiting the role of protein-induced satiation and satiety. Food Hydrocolloids. 2017;68:199-210

[84] Weigle DS, Breen PA, Matthys CC, Callahan HS, Meeuws KE, Burden VR, et al. A high-protein diet induces sustained reductions in appetite, ad libitum caloric intake, and body weight despite compensatory changes in diurnal plasma leptin and ghrelin concentrations. The American Journal of Clinical Nutrition. 2005;82(1):41-48

[85] Rosenbloom C. Popular diets and athletes: Premises, promises, pros, and pitfalls of diets and what athletes should know about diets and sports performance. Nutrition Today. 2014;49(5):244

[86] Rogerson D. Vegan diets: Practical advice for athletes and exercisers. Journal of the International Society of Sports Nutrition. 2017;14(1):36. DOI: 10.1186/s12970-017-0192-9

[87] Saturni L, Ferretti G, Bacchetti T. The gluten-free diet: Safety and nutritional quality. Nutrients. 2010;2(1):16-34

[88] Gearhart CM, Rosentrater KA. Extrusion processing of amaranth and quinoa. Montreal, Quebec Canada: 13. Jul 2014;13:1

[89] Bressani R, Kalinowski LS, OrtizMA, Elías LG. Nutritional evaluation of roasted, flaked and popped $A$. caudatus. Archivos Latinoamericanos de Nutrición. 1987;37(3):525-531

[90] Bressani R, Martell ECMD, Godínez CMD. Protein quality evaluation of amaranth in adult humans. Plant Food for Human Nutrition. 1993;43(2):123-143

[91] de la Barca AMC, Rojas-Martínez ME, Islas-Rubio AR, Cabrera-Chávez F. Gluten-free breads and cookies of raw and popped amaranth flours with attractive technological and nutritional qualities. Plant Foods for Human Nutrition. 2010;65(3):241-246

[92] Sharanya Rani D. Development of grain amaranth based nutrient rich snack bars [thesis]. Acharya Ng Ranga Agricultural University; 2011

[93] Singhal RS, Kulkarni PR. Amaranthsan underutilized resource. International Journal of Food Science and Technology. 1988;23(2):125-139

[94] Dixit AA, Azar KM, Gardner CD, Palaniappan LP. Incorporation of whole, ancient grains into a modern 
Asian Indian diet to reduce the burden of chronic disease. Nutrition Reviews. 2011;69(8):479-488

[95] Schoenfeld ML. Nutritional considerations for the female vegan athlete. Strength \& Conditioning Journal. 3 Jun 2019

[96] Goncharov N, Maevsky E, Voitenko N, Novozhilov A, Kubasov I, Jenkins R, et al. Nutraceuticals in sports activities and fatigue. In Nutraceuticals. Academic Press; 1 Jan 2016. pp. 177-188. Available from: http://linkinghub. elsevier.com/retrieve/pii/ B9780128021477000140

[97] He H-P, Cai Y, Sun M, Corke H. Extraction and purification of squalene from amaranthus grain. Journal of Agricultural and Food Chemistry. 2002;50(2):368-372

[98] Betschart AA, Irving DW, Shepherd AD, Saunders RM. Amaranthus Cruentus: Milling characteristics, distribution of nutrients within seed components, and the effects of temperature on nutritional quality. Journal of Food Science. 1981;46(4):1181-1187

[99] Espitia Rangel E. Amaranto: Ciencia y Tecnología. Celaya, Guanajuato: Instituto Nacional de Investigaciones Forestales, Agrícolas y Pecuarias, Mejoramiento Genético de Cereales (Amaranto, Avena y Trigo): Sistema Nacional de Recursos Fitogenéticos para la Alimentación y la Agricultura; 2012

[100] Tyszka-Czochara M, Pasko P, Zagrodzki P, Gajdzik E, Wietecha-Posluszny R, Gorinstein S. Selenium supplementation of amaranth sprouts influences betacyanin content and improves antiinflammatory properties via $\mathrm{NF} \kappa \mathrm{B}$ in Murine RAW 264.7 macrophages. Biological Trace Element Research. 2016;169(2):320-330
[101] Khandaker L, Ali MB, Oba S. Total polyphenol and antioxidant activity of red amaranth (Amaranthus tricolor L.) as affected by different sunlight level. Journal of the Japanese Society for Horticultural Science. 2008;77(4):395-401

[102] Bojórquez-Velázquez E, Barrera-Pacheco A, Espitia-Rangel E, Herrera-Estrella A, Barba de la Rosa AP. Protein analysis reveals differential accumulation of late embryogenesis abundant and storage proteins in seeds of wild and cultivated amaranth species. BMC Plant Biology. 2019;19(1):59

[103] De Ruiz AC, Bressani R. Effect of germination on the chemical composition and nutritive value of amaranth grain. Cereal Chemistry. 1990;67(6):519-522

[104] Cornejo F, Novillo G, Villacrés E, Rosell CM. Evaluation of the physicochemical and nutritional changes in two amaranth species (Amaranthus quitensis and Amaranthus caudatus) after germination.

Food Research International.

2019;121:933-939

[105] Prakash D, Joshi BD, Pal M. Vitamin $C$ in leaves and seed oil composition of the Amaranthus species. International Journal of Food Sciences and Nutrition. 1995;46(1):47-51

[106] Tauler P, Aguiló A, Gimeno I, Fuentespina E, Tur JA, Pons A. Influence of vitamin $C$ diet supplementation on endogenous antioxidant defences during exhaustive exercise. Pflügers Archiv - European Journal of Physiology. 2003;446(6):658-664

[107] Marcilío R, Amaya-Farfan J, Silva M, Spehar C. Avaliação da farinha de amaranto na elaboração de biscoito sem glúten do tipo cookie. 
Brazilian Journal of Food Technology. 2005;8(2):175-181

[108] Cárdenas-Torres FI, ReyesMoreno C, de Jesús Vergara-Jiménez M, Cuevas-Rodríguez EO, Milán-Carrillo J, Gutiérrez-Dorado R, et al. Assessing the sensitizing and allergenic potential of the albumin and globulin fractions from amaranth (Amaranthus hypochondriacus) grains before and after an extrusion process. Medicina. 2019;55(3):E72

[109] Queiroz YS, Manólio RS, Capriles VD, Torres EA, Areas JA. Effect of processing on the antioxidant activity of amaranth grain. Archivos Latinoamericanos de Nutrición. 2009;59(4):419-424

[110] Negi PS, Roy SK. Changes in $\beta$-carotene and ascorbic acid content of fresh amaranth and fenugreek leaves during storage by low cost technique. Plant Foods for Human Nutrition. 2003;58(3):225-230

[111] Hozová B, Buchtová V, Dodok L, Zemanovic J. Microbiological, nutritional and sensory aspects of stored amaranth biscuits and amaranth crackers. Die Nahrung. 1997;41(3):155-158

[112] Montoya-Rodríguez A, de Mejía EG, Dia VP, Reyes-Moreno C, Milán-Carrillo J. Extrusion improved the anti-inflammatory effect of amaranth (Amaranthus hypochondriacus) hydrolysates in LPS-induced human THP-1 macrophage-like and mouse RAW 264.7 macrophages by preventing activation of NF- $\mathrm{KB}$ signaling. Molecular Nutrition \& Food Research. 2014;58(5):1028-1041

[113] Repo-Carrasco-Valencia R, Peña J, Kallio H, Salminen S. Dietary fiber and other functional components in two varieties of crude and extruded kiwicha (Amaranthus caudatus). Journal of Cereal Science. 2009;49(2):219-224
[114] Caselato-Sousa VM, Amaya-Farfán J. State of knowledge on amaranth grain: A comprehensive review. Journal of Food Science. 2012;77(4):R93-R104

[115] Singhal RS, Kulkarni PR. Effect of puffing on oil characteristics of amaranth (Rajgeera) seeds. Journal of the American Oil Chemists' Society. 1990;67(12):952-954

[116] Kunle. Standardization of herbal medicines-A review. International Journal of Biodiversity and Conservation. 2012;4(3):101112. Available from: http://www. academicjournals.org/ijbc/abstracts/ abstracts/abstracts2012/March/ Kunle\%20et\%20al.htm

[117] Sun H, Wiesenborn D, Tostenson K, Gillespie J, Rayas-Duarte P. Fractionation of squalene from amaranth seed oil. Journal of the American Oil Chemists' Society. 1997;74(4):413-418 



\title{
Nutritional Functional Value and Therapeutic Utilization of Amaranth
}

\author{
Manuel Soriano-García and Isabel Saraid Aguirre-Díaz
}

\begin{abstract}
Amaranthus is a dicotyledonous pseudocereal and one of the New World's oldest crops, having originated in Mesoamerica, and was a major food crop of the Aztecs who named it Huautli or Xtes. Popularity in the cultivation and consumption of Amaranthus seed in the modern era began in the mid-1970s with the rediscovery and promotion of amaranth due to its superior nutritional attributes as compared to cereal grains. Today, amaranth is still included in the human diet because of its nutraceutical relevance. Amaranth is considered as a "superfood" because it contains high nutraceutical values such as a high-quality protein, unsaturated oils, squalene, dietary fiber, tocopherols, tocotrienols, phenolic compounds, flavonoids, vitamins, and minerals. Compared to other grains, amaranth has a higher amount of protein, dietary fiber, calcium, iron, and magnesium; therefore although it is an ancient crop nowadays, it is considered a millennium crop or superfood with relevant nutraceutical values and its agronomic versatility. This comprehensive chapter is focused on amaranth composition and antioxidant properties and provides several potential medical benefits of its valuable components.
\end{abstract}

Keywords: Amaranthus spp., Amaranthus hypochondriacus, superfood, nutritional functional value, therapeutic utilization

\section{Introduction}

Amaranthus is a dicotyledonous pseudocereal and one of the New World's oldest crops, having originated in Mesoamerica. The family Amaranthaceae is generally considered as the "amaranth family." The word Amaranthus is basically derived from the Greek word "anthos" (flower) which means everlasting or unwilting. Amaranth (Amaranthus spp.) has been consumed throughout history, by the Inca, Maya, and Aztec civilizations. Amaranth was a part of the daily diet, in addition to corn and beans. At the present time, it is also called the third millennium crop plant [1]. Currently it is widely cultivated and consumed throughout India, Nepal, China, Indonesia, Malaysia, and the Philippines; whole of Central America, Mexico; and Southern and Eastern Africa. The species grown for human consumption are Amaranthus hypochondriacus, A. cruentus, and A. caudatus. Since pre-Hispanic time, every part of the Amaranthus hypochondriacus plant has been broadly used in Mexico, especially the seeds. Amaranth is a plant with annual growth, fast-growing with several different colors, and is reproduced by self-pollination by the wind. This plant has a high resistance to drought and a variety of weather conditions. 


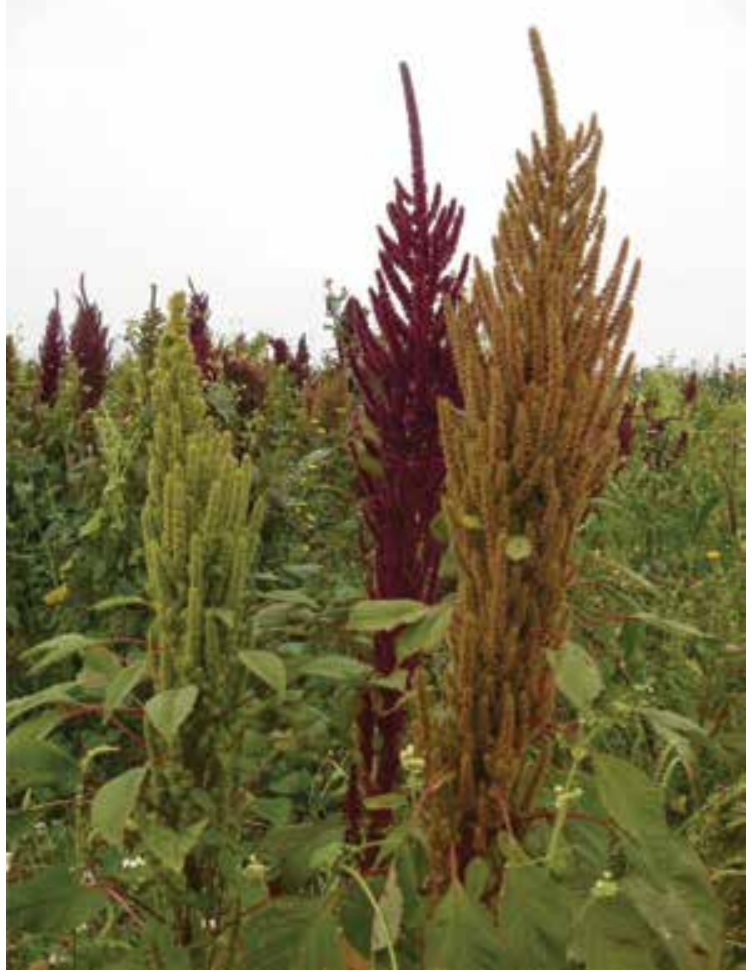

Figure 1.

Amaranthus hypochondriacus plant.

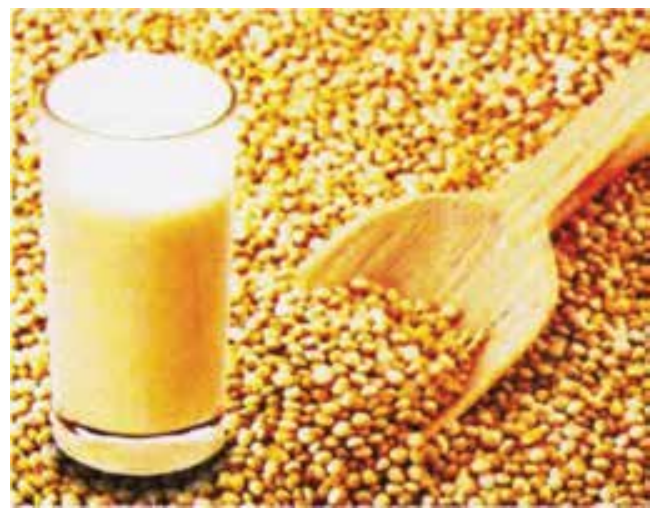

Figure 2.

Amaranth grain from which a nutritional beverage is prepared.

The domesticated species is A. hypochondriacus which is mainly harvested in the States of Guerrero, Morelos, Michoacán, Queretaro, Puebla, and Tlaxcala [2].

There has been an increased interest in amaranth since it appeared in the 1980s, when the US National Academy of Sciences carried out a research project entitled Underexploited Tropical Plants with Promising Economic Value, at that time amaranth was elected from among 36 of the world's most promising crops and identified as a major potential crop; since then, extensive research has been carried out [3]. Research has been performed on the grain which has allowed to describe its high nutritional value and agronomic potential [4]. 
Figure 1 shows the Amaranthus hypochondriacus plant and can be easily recognized among other crops as each plant has an "immortal colorful flower" that, based on our own experience, contains more than $1 \mathrm{~kg}$ of seeds each big flower. Figure 2 shows that amaranth grain morphology is smooth, with slightly golden color, shiny, and slightly flattened with a lens-shaped form. Its size varies between 1.1 and $1.4 \mathrm{~mm}$ in length and 1.0 and $13 \mathrm{~mm}$ in width, while its weight is around 0.6 and $1.0 \mathrm{mg}$.

\section{Amaranth description and composition}

Amaranth (Amaranthus hypochondriacus) belongs to the Amaranthaceae family: the seeds are rich in macronutrients including proteins, dietary fiber, and fats (Table 1) and micronutrients such as vitamins and minerals (Table 2). Extensive reviews of the past two decades have shown that amaranth seeds have abundant protein content ranging from 13 to $19 \%$ with an outstanding balance of essential amino acids [5]. Besides, the amaranth seeds contain higher levels of oils rich in squalene, have high lipid and starch, and also contain a high amount of antioxidants [6].

It is known that celiac disease is a serious autoimmune disease that occurs in genetically predisposed people where the ingestion of gluten leads to damage in the small intestine. It is estimated to affect 1 in 100 people worldwide. Amaranth seed is gluten-free and may be used to prepare nutritious and suitable food products for people with this type of food allergy.

Herein essential amino acids, fatty acid composition, and phytonutrients of amaranth grain are given in Tables 3-5, respectively.

The essential amino acid profile of amaranth grain is given in Table 3.

The lipid contents in amaranth grain is around 7-9\% higher as the values found in other cereals such as wheat and maize with values of 2.1 and $4.5 \%$, respectively. Amaranth grain contains mainly unsaturated fats, containing linoleic (or omega-6) fatty acid (25-62\%) and alpha-linolenic (or omega-3) fatty acid (0.3-2.2\%) [7]. The fatty acid composition of amaranth grain is given in Table 4.

Amaranth grain flour contains mainly polyphenols (flavonoids) and phenolic acids with relatively high antioxidant activity. Both flavonoids and phenolic acid composition of amaranth grain are given in Table 5.

The amaranth grain contains more protein than other crops as corn and rice [13] and a relatively high content of several essential amino acids as shown in Table 3. Lysine is the principal component which limits amino acid in cereals like maize, wheat, and rice. Lysine in protein ranges from 40 to $50 \mathrm{~g} / \mathrm{kg}$. The essential amino acid index (EAAI) value of $90.4 \%$ showed that amaranth's protein is comparable

\begin{tabular}{lc}
\hline Component & Amaranth grain (value per 100 g) \\
\hline Protein & 13.56 \\
\hline Lipids & 7.02 \\
\hline Carbohydrates & 65.25 \\
\hline Dietary fiber & 6.70 \\
\hline Ash & 2.88 \\
\hline Water & 11.29 \\
\hline Energy (kcal; kJ) & $371 ; 1554$ \\
\hline
\end{tabular}

Table 1.

Nutrient composition and energy content of amaranth grain [7]. 


\begin{tabular}{|c|c|}
\hline & Amaranth grain (g per $100 \mathrm{~g})$ \\
\hline \multicolumn{2}{|l|}{ Minerals } \\
\hline Calcium & $159 \mathrm{mg}$ \\
\hline Copper & $0.53 \mathrm{mg}$ \\
\hline Iron & $7.61 \mathrm{mg}$ \\
\hline Magnesium & $248 \mathrm{mg}$ \\
\hline Manganese & $3.33 \mathrm{mg}$ \\
\hline Phosphorus & $557 \mathrm{mg}$ \\
\hline Potassium & $508 \mathrm{mg}$ \\
\hline Sodium & $4 \mathrm{mg}$ \\
\hline Zinc & $2.87 \mathrm{mg}$ \\
\hline Selenium & $18.7 \mathrm{mcg}$ \\
\hline \multicolumn{2}{|l|}{ Vitamins } \\
\hline Ascorbic acid & $4.20 \mathrm{mg}$ \\
\hline Riboflavin & $0.20 \mathrm{mg}$ \\
\hline Folate & $82 \mathrm{mcg}$ \\
\hline Niacin & $0.92 \mathrm{mg}$ \\
\hline Thiamin & $0.12 \mathrm{mg}$ \\
\hline Vitamin A & $2 \mathrm{IU}$ \\
\hline Pantothenic acid, vit. B55 & $1.46 \mathrm{mg}$ \\
\hline Vitamin B-6 & $0.59 \mathrm{mg}$ \\
\hline Vitamin E (alpha-tocopherol) & $1.19 \mathrm{mg}$ \\
\hline Vitamin E (beta-tocopherol) & $0.96 \mathrm{mg}$ \\
\hline Vitamin E (delta-tocopherol) & $0.69 \mathrm{mg}$ \\
\hline Choline & $69.8 \mathrm{mg}$ \\
\hline Betaine & $67.6 \mathrm{mg}$ \\
\hline Lutein & $28 \mathrm{mcg}$ \\
\hline
\end{tabular}

Table 2.

Minerals and vitamins composition of amaranth grain [7].

with egg protein and can be used as a substitute for a meal [14]. Also there is a high amount of protein in amaranth's leaves [15]. Additionally, in amaranth's grain, besides omega-6, omega-3, oleic, palmitic, and stearic acids (Table 4), also another nutraceutical constituent is squalene [16]. As shown herein through Tables 1-4, amaranth grain contains a well-balanced proportion as relevant nutrient for human diet. Starch is the main component of amaranth grain and has been used in many healthy and organic food preparations [17]. As compared to the starch in corn and wheat, the starches of $A$. cruentus and $A$. hypochondriacus both have a higher swelling power or absorbance capacity, lower solubility, greater uptake, lower susceptibility to amylases, and lower amylase content (4.7-12.5\%) [18].

Besides proteins, carbohydrates, and lipids, amaranth seeds contain various other constituents (Tables 4 and 5), making amaranth a superfood because it also counts with elevated levels of vitamin E, vitamin B2 (riboflavin), and vitamin C (ascorbic acid). It is also important to mention that saponins are found in very low levels $(0.1 \%)$ in amaranth grain which makes it completely safe for human consumption [19]. 
Nutritional Functional Value and Therapeutic Utilization of Amaranth

DOI: http://dx.doi.org/10.5772/intechopen.86897

\begin{tabular}{lc}
\hline Components & Amaranth grain (g per 100 g) \\
\hline Arginine & 1.06 \\
\hline Histidine & 0.39 \\
\hline Isoleucine & 0.58 \\
\hline Leucine & 0.88 \\
\hline Lysine & 0.75 \\
\hline Methionine & 0.23 \\
\hline Phenylalanine & 0.54 \\
\hline Threonine & 0.56 \\
\hline Tryptophan & 0.18 \\
\hline Valine & 0.68 \\
\hline
\end{tabular}

Table 3

Essential amino acid profile of amaranth grain [7].

\begin{tabular}{lc}
\hline Component & Amaranth grain (value per 100 g) \\
\hline Palmitic acid (C16:0) & 1.154 \\
\hline Stearic acid (C18:0) & 0.223 \\
\hline Oleic acid (C18:1) & 1.671 \\
\hline Linoleic acid (C18:2) $\omega-6$ & 2.736 \\
\hline Linolenic acid (C18:3) $\omega-3$ & 0.042 \\
\hline
\end{tabular}

Table 4.

Fatty acid composition of amaranth grain oil [7].

\begin{tabular}{|c|c|}
\hline Components & Amaranth grain (mcg/g) \\
\hline \multicolumn{2}{|c|}{ Flavonoids (polyphenols) } \\
\hline Quercetin & $68^{\mathrm{a}}(18)$ \\
\hline Nicotiflorin & $6^{\mathrm{b}}(6)$ \\
\hline Rutin & $6.15^{b}(6)$ \\
\hline \multicolumn{2}{|l|}{ Phenolic acids } \\
\hline Ferulic acid & $310^{c}(9)$ \\
\hline Gallic acid & $41^{\mathrm{d}}(5)$ \\
\hline Caffeic acid & $6.5^{\mathrm{c}}(9)$ \\
\hline p-Coumaric acid & $1.2^{\mathrm{c}}(9)$ \\
\hline Isoquercitrin & $0.4(6)$ \\
\hline Anthocyanins & $35.2^{\mathrm{e}}(17)$ \\
\hline Syringic acid & $0.8^{\mathrm{b}}(6)$ \\
\hline Vanillic acid & $1.7^{\mathrm{b}}(6)$ \\
\hline $\begin{array}{l}{ }^{a} \text { Kalinova and Dadak } \\
{ }^{b} \text { Barba de la Rosa et a } \\
{ }^{c} \text { Gorinstein et al. [10] } \\
{ }^{d} \text { Klimczak et al. [11] } \\
{ }^{e} \text { López et al. [12] }\end{array}$ & \\
\hline
\end{tabular}

Table 5.

Phytonutrients in amaranth grain. 
Among other relevant facts that convert amaranth into a superfood is that it is considered as a good source of insoluble fiber with a content of $4.2 \%$ [17]. Both insoluble and soluble fibers have known health benefits such as reducing cholesterol and promoting gut health. Amaranth flours have been shown to have antioxidant activity due to flavonoids (polyphenols from secondary metabolites) found in the seed. Three flavonoids have been identified, rutin, isoquercitrin, and nicotiflorin, and several health benefits are known to be caused by these compounds [8] (see Table 5).

\section{Amaranth benefits}

\subsection{High source of protein}

Mexican consumers are looking for natural products that improve their health. However, our modern society tends to consume processed foods. These foods typically contain increased amounts of salt, sugar, fat, additives, or preservatives in order to improve their taste and texture or to extend shelf life-all of which are known as harmful. In my research group, we have special interest in using plants that were used in our ancient civilizations. This is the case of Amaranthus hypochondriacus which has a high concentration of protein, oil, minerals, vitamins, and antioxidants.

The protein contained in amaranth is of an unusually high quality due to its outstanding balance and high content of essential amino acids (Table 3). The essential amino acids in amaranth grain are ideal according to the World Health Organization (WHO) and Food and Agriculture Organization of the United Nations (FAO). For instance, the amount of lysine and tryptophan present in amaranth grain are relatively higher than those found in wheat, rice, and maize grains, but it is deficient in leucine.

Protein is used in every single cell in our bodies and is critical for building muscle mass, supporting neurological function, aiding in digestion, helping to balance hormones naturally, and keeping an upbeat mood which suggests that this protein is useful for muscle recovery and the immune system for athletic performance [20, 21].

\subsection{Reduce inflammation}

It is well documented that inflammation is a normal immune response designed to protect the body against injury and infection. If the inflammation process continues in your body, this could contribute and be associated with chronic diseases, such as cancer, diabetes, and autoimmune disorders.

The intake of amaranth could help to avoid diseases caused by inflammation because it has been described that extruded amaranth protein hydrolysates prevented inflammation by the activation of bioactive peptides that reduced the expression of several pro-inflammatory markers [22]. That is the reason why consumption of amaranth grain could help to reduce inflammation [23]. In this context, it is recommended to include amaranth grain in the diet in order to reduce inflammation and may help to prevent chronic diseases derived from inflammation process.

\subsection{Bone health}

Calcium is a key player in the generation and maintenance of healthy bones as it supports mineralization [24]. Amaranth contains more calcium than other seeds, which makes it a valuable food that helps to have a healthy development of bones helping to prevent osteoporosis $[25,26]$. Therefore, the intake of extruded amaranth products could help to improve the proper intake of calcium to support healthier bones [27]. 


\subsection{Amaranth as a cardioprotective}

It has been proven that amaranth's oil can reduce total and bad cholesterol (LDL) increasing good cholesterol as tested in animal models by Berger et al. [28]. Also it has been proven that amaranth affected absorption of cholesterol and bile acids, cholesterol lipoprotein distribution, hepatic cholesterol content, and cholesterol biosynthesis [29].

\subsection{Fights duodenal peptic ulcer}

It is well known that various plant-originated "gastroprotectors" with different compositions have been used in clinical and folk medicine due to their beneficial effects on the mucosa of gastrointestinal tract. Ethanolic and ethyl-acetate leaf extracts of $A$. tricolor showed gastric-ulcer healing effect in acetic acid-induced chronic gastric ulcers and gastric cytoprotective effect in ethanol and indomethacininduced gastric ulcers in pylorus-ligated rats [30]. A combined use of this extract with two other herbs will help to improve the antiulcer properties [31].

It has been found that duodenal peptic ulcer and chronic gastritis caused by Helicobacter pylori can be treated with amaranth oil [32].

\subsection{Fights diabetes}

Diabetes is a metabolic disorder where the body does not produce insulin or does not use it efficiently during the body's ability to process blood glucose. Consequently, it can lead to dangerous complications, including stroke, heart disease, kidney failure, and diabetic retinopathy, among other problems, it has been reported that amaranth grain and oil have an antioxidative effect on streptozotocininduced diabetic rats [33]; grains and oils used as supplements may be beneficial for correcting hyperglycemia as part of an antioxidant therapy.

Manganese, besides regulating blood glucose, can boost the immune function [34]. Also it is known that manganese is needed in adequate levels to avoid abnormalities in cholesterol levels, skin and bone health [35], and renal health [36]. Another relevant benefit obtained when amaranth is included in diet is that due to its high amount of manganese, it represents a good option for regulating sugar levels. In the organism as manganese helps during gluconeogenesis, in this way, when manganese is obtained in a sufficient amount by consuming amaranth, it is possible to protect against diet-induced diabetes [37].

It has been shown that the influence of dietary therapy which uses sunflower and amaranth oils on parameters of immune reactivity in patients with diabetes mellitus type 2 [38] and the activation of aerobic metabolism by amaranth oil improve heart rate variability both in athletes and patients with diabetes [39].

\subsection{Amaranth is gluten-free}

Celiac disease is a serious disorder in which eating gluten, a protein found in wheat, barley, and rye, triggers an immune response in the body, causing inflammation and damaging the lining of the small intestine. The damage of the small intestine's lining causes a poor absorption of some nutrients, diarrhea, fatigue, weight loss, poor memory, joint paint, bloating, and anemia, among other symptoms.

Recently amaranth grain has gained more relevance because it is a gluten-free pseudocereal being an alternative option when cereals, such as wheat, barley, and rye, which do contain gluten, cannot be consumed because they cause food allergies. Amaranth is also an excellent protein choice for a healthier life and better 
performance for athletes, vegans, vegetarians, and those persons that had acquired allergies or have celiac disease.

Amaranth is an excellent protein source for persons that are non-celiac gluten sensitivity (NCGS) who later on acquire gluten intolerance and also for those that born with celiac disease [40-42].

\subsection{Helps pregnant women}

Folic acid is the synthesized stable oxidized form of an essential water-soluble B9-complex vitamin that occurs naturally as various folates, usually in reduced form. Folic acid is very important for the development of a healthy fetus. Folic acid can be taken as a supplement tablet and food fortification, while folates are found naturally in foods. Folates play an important role in single-carbon transfer reactions, in several metabolic pathways including the synthesis of purines and pyrimidines, and, hence, in the formation of DNA and RNA. These actions have complex relations with other essential vitamins, especially vitamin B12 [43]. Prior to 1996, the principal food sources for folates were dark green leafy vegetables, organ meats, eggs, and citrus fruits. A severe deficiency of folate manifests as an anemia characterized by many large immature and dysfunctional red blood cells (megaloblasts).

For pregnant women, a folate deficiency can lead to neural tube defects such as spina bifida. A deficiency can also cause defects such as heart and limb malformations. The folate in amaranth helps the body make new cells, specifically by playing a role in copying and synthesizing DNA. There is $88.0 \mathrm{mcg}$ of folate in amaranth grain (see Table 2). Fortification of foods with folate by the FDA has decreased the risk for neural tube defects by $26 \%$ [44].

\subsection{Amaranth prevents constipation}

Amaranth is an excellent source of high soluble fiber. The daily recommended dietary fiber intake for men and women are 38 and $25 \mathrm{~g}$, respectively. Dietary fiber may help prevent constipation, making one's bowel movement easier to manage. Constipation clearly means the gut is overburdened, so it helps to combine amaranth grain with dark leafy greens, specially spinach; most nuts; seeds, specially pumpkin and sunflower seeds; fish; beans; whole grains; avocados; yogurt; bananas; dried fruit; eggplant; and unsweetened cocoa.

Amaranth starch binds water and thus helps to prevent constipation. The large content of fiber in amaranth grain is of great advantage [45]. Fiber is an important part of human nutrition. In developed industrial countries, i.e., to the Czech Republic, there is lack of dietary fiber in food, and the content of fiber corresponds to the figures recommended by the World Health Organization (WHO) [46].

\subsection{Amaranth has antioxidant activity}

Antioxidants are substances that reduce the effect of free radicals. These compounds inhibit oxidation; they help your heart health and may lower your risk of infections and some forms of cancer and degenerative disorders. Antioxidant potential has been attributed to the presence of appreciable levels of phenolics and flavonoids. Leaves and flowers of Amaranthus as well as their extracts were shown to possess the highest antioxidant activities compared to other parts, rutin being the major radical scavenger [47]. From a practical point of view, these antioxidants may also be used to counteract the deterioration of stored food products. 


\subsection{Amaranth has antimicrobial activity}

An antimicrobial is a natural or synthetic agent that kills microorganisms or slows the spread of microorganisms such as bacteria, fungi, and algae. Amaranthus sp. antimicrobial properties have been studied and exploited by mankind for several decades. The roots, leaves, and seeds of Amaranthus spp. have been used in the evaluation of its antimicrobial activities against Gram-positive and Gram-negative bacteria, such as Bacillus subtilis, B. bronchiseptica, Bacillus cereus, B. pumilus, Micrococcus flavus, S. aureus, Sarcina lutea, E. coli, and P. vulgaris, among others $[48,49]$. For the last 10 years, our research group has been working in antimicrobial peptides due to great interest to overcome the growing problem of antimicrobial resistance. An antifungal peptide called Ay-AMP was isolated from Amaranthus hypochondriacus seeds by acidic extraction and then purified by reverse-phase highpressure liquid chromatography [50].

\subsection{Amaranth as a hepatoprotective}

A study carried out by Zeashan et al. [51] showed the hepatoprotective and antioxidant activity of $50 \%$ ethanolic extract of a whole plant of Amaranthus spinosus using carbon tetrachloride-induced hepatic damage in rats. Furthermore, this study suggests that possible mechanism of this activity may be due to the presence of flavonoid and phenolic compound in the A. spinosus which may be responsible to hepatoprotective activity [51]. Additional study was carried out using the ethanolic extract of Amaranthus tricolor L. leaves, to test its efficacy against $\mathrm{CCl} 4$-induced liver toxicity in rats. The results indicate that $A$. tricolor extract significantly increases the activities of nonprotein sulfhydryl (NP-SH) and total protein (TP) in liver tissue supporting the evaluation of the liver histopathology in rats [52].

\subsection{Amaranth as an anticancer}

According to the Cancer Research Institute, cancer is the name given to a collection of related diseases. In all types of cancer, some of the body's cells begin to divide without stopping and spread into surrounding tissues. Cancer can start almost anywhere in the human body, which is made up of trillions of cells. Normally, human cells grow and divide to form new cells as the body needs them. It happens that when cells grow old or become damaged, they die, and new cells take their place. When cancer develops, however, this orderly process breaks down. As cells become more and more abnormal, old or damaged cells survive when they should die, and new cells form when they are not needed. These extra cells can divide without stopping and may form growths called tumors.

In vitro assay of antiproliferative potential of Amaranthus cruentus aqueous extract on human peripheral blood lymphocytes has been reported by Gandhi et al. [53]. Later on it has been reported that hexane, ethyl-acetate, and methanolic extracts of $A$. tristis Roxb. showed antiproliferative properties with minimum side effects as determined in human colon adenocarcinoma cell line (COLO-320-DM) [54].

Recently, Peters and Gandhi reported more experimental evidence regarding the antitumor potential of various amaranth leaf extracts using different solvent with significant antitumor potential. These authors stated that leaf extract should further be explored as a novel source of cancer therapy [47]. 


\subsection{Amaranth as an antimalarial}

Malaria is an infectious disease caused by protozoan parasites from the Plasmodium family that can be transmitted by the bite of the Anopheles mosquito or by a contaminated needle or transfusion. In this context, falciparum malaria is the most deadly type. The symptoms of malaria include cycles of chills, fever, sweats, muscle aches, and headache that recur every few days. There can also be vomiting, diarrhea, coughing, and yellowing (jaundice) of the skin and eyes. Persons with severe falciparum malaria can develop bleeding problems, shock, kidney and liver failure, central nervous system problems, coma, and death. Travelers to areas with malaria are advised to take medications to prevent infection if exposed [55].

Extracts obtained from two Burkinabe folk medicine plants, both spiny amaranth (Amaranthus spinosus L., Amaranthaceae) and erect spiderling (Boerhavia erecta L., Nyctaginaceae) were screened for antimalarial properties with the aim of testing the validity of their traditional uses. The plant extracts showed significant antimalarial activities in the 4-day suppressive antimalarial assay in mice inoculated with red blood cells parasitized with Plasmodium berghei [56].

A combination of two plant extracts of Launaea taraxacifolia and Amaranthus viridis is used by people of Western Africa in the treatment of malaria and related symptoms. This study assessed for their antiplasmodial value against the chloroquine-sensitive strain of Plasmodium berghei. This study showed that the methanolic extracts of $A$. viridis and L. taraxacifolia possess antiplasmodial activity [57].

\subsection{Amaranth with an antianemic effect}

Anemia is defined as a low level of hemoglobin in red blood cells. The major clinical symptom of anemia and iron deficiency shows a pale color of the skin, and its physical symptom is fatigue. According to the UNICEF, anemia has an impact on the intellectual development of children; it reduces learning ability and growth and damages the immune system.

Mexico is an underdeveloped country with malnutrition conditions. In our country, anemia is a public health problem generalized in all social socioeconomic status. Amaranthus has been rediscovered as a promising food crop mainly due to its resistance to heat, drought, diseases and pests, and the high nutritional value of both seeds and leaves. They are rich in proteins and micronutrients such as iron, calcium, zinc, vitamin C, and vitamin A shown in Tables 1 and 2.

Iron deficiency anemia is a major public health problem in young children in developing countries and is associated with impaired cognitive development and morbidity. Our research group had been developing a nutraceutical formulation in a powder form that treats the prevalence of anemia in Mexican children, adolescents, and in general all adults in México. The nutraceutical formulation is called "Naturalmente Alegría" (Naturally Joy) (Figure 3), and it has been approved by the Federal Committee for Protection from Sanitary Risks in Mexico (COFEPRIS). The product has been consumed by several thousands of Mexicans with anemia to date.

\subsection{Amaranth as a nutraceutical/supplementary food}

Extracts of all plant parts of Amaranthus seem to have medicinal benefits; hence the focus of recent studies has been to identify therapeutic constituents of Amaranthus from roots, plant stem, leaves, flowers, and seeds. Due to its high content of quality proteins with nine essential amino acids, unsaturated fatty acids, and squalene, high antioxidant activity (tocopherols and tocotrienols) of most Amaranthus spp., along with anti-inflammatory property, has increased 


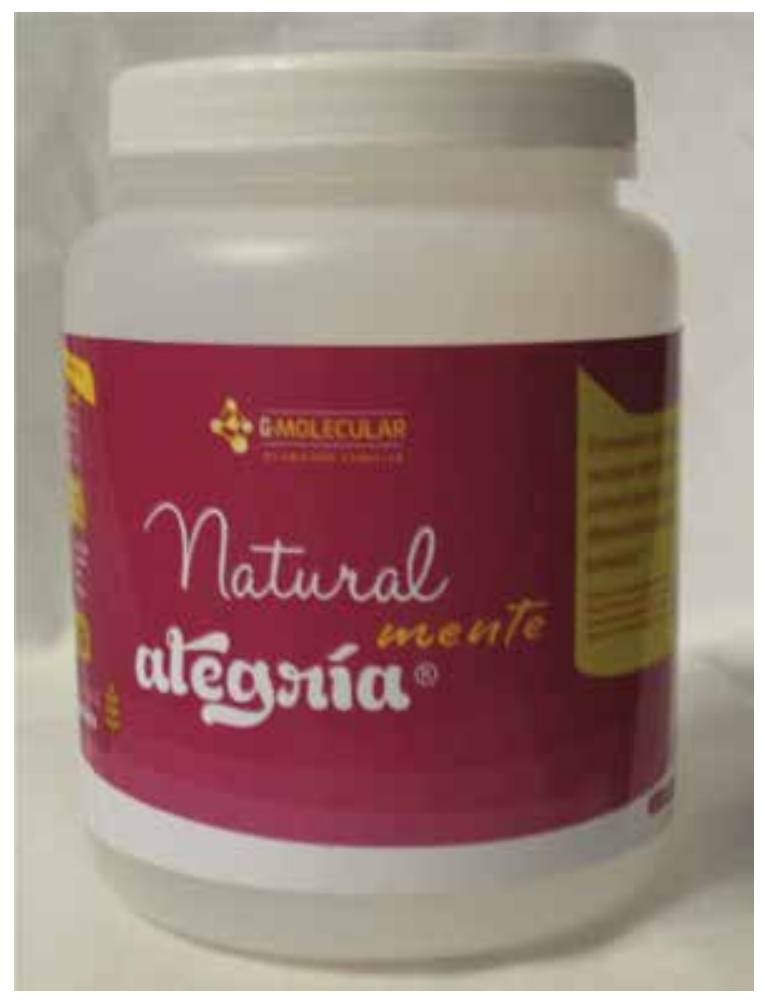

Figure 3.

Naturalmente Alegría (Naturally Joy), a nutraceutical product from Amaranthus hypochondriacus.

interest in investigating its nutraceutical and clinical potential as a functional food. Amaranthus hypochondriacus seed has proteins with very high levels of tryptophan and lysine which are unique compared to other grains. More nutraceutical/supplementary food information is described by Peter and Gandhi [47].

\subsection{Other properties}

Since pre-Hispanic time, every part of the Amaranthus hypochondriacus plant has been used in Mexico, especially the seeds. Nowadays, some oligopeptides and proteins have already been isolated in our laboratory, such as nonspecific lipidtransfer protein (nsLTP1) with $9.7 \mathrm{kDa}$ [58], which plays a role in the plant defense, and a globulin of $34.9 \mathrm{kDa}$ [20] which is a storage protein very important in nutrient conservation; an oligopeptide derived from enzymatic digestion of globulins from amaranth shows strong affinity binding to the replication origin of Tomato yellow leaf curl virus reducing viral replication in Nicotiana benthamiana [59].

\section{Discussion}

The importance of amaranth as a functional food has resurged in the last years. Amaranthus hypochondriacus grain has an excellent nutrient composition with a high concentration of proteins (13-19\%) and bioactive peptides [60]. As a matter of fact, amaranth helps as antihypertensive, antioxidant, antithrombotic, and antiproliferative biological activities, among others. These peptides are encrypted within the proteins, and only after the enzymatic digestion or food processing are they released. Some studies using amaranth flour and protein isolates reported the 
occurrence of peptides with biological activities such as antihypertensive, antioxidant, antithrombotic, and antiproliferative, among others [61, 62].

The Amaranthaceae family consists of 60 genera and about 800 species. Sixty of these species are cosmopolitan and grow particularly in areas of human activities where they are regarded as weeds. Of these 60 species, only 3 are considered good seed producers: Amaranthus hypochondriacus (the main variety grown in Mexico), A. cruentus, and $A$. caudatus. In these three Amaranthus species, both leaves and seeds contain protein of high quality. The grain is milled for flour or popped like popcorn. The leaves of both species may be eaten raw or cooked. Amaranth is a fast-growing crop, and because of its low production cost, it is one of the cheapest plants. This plant grows under varied soil and agroclimatic conditions and is also resistant to heat and drought with no major disease problems [63].

The amaranth composition includes carbohydrates, dietary fiber, lipids and proteins, and other important constituents, such as squalene, tocopherols, phenolic compounds, flavonoids, phytates, vitamins, and minerals. This comprehensive chapter is focused on amaranth composition and antioxidant properties and provides several potential medical benefits of its valuable components. Thus, amaranth and their products should be considered as a future crop with nutritional and medical purposes in many countries.

\section{Conclusions}

Existing evidence suggests that nutrition, especially staple-based foods such as amaranth, when part of a balanced pattern, contributes with important protein, polyunsaturated fatty acids, minerals (calcium, zinc, iron, magnesium, and manganese, among other minerals), appropriate dietary fiber, vitamins, and antioxidants that can help mitigate or reduce the risk of several diseases.

This chapter is based on scientific knowledge and personal experience working with amaranth plant. I would like to apologize to anyone who finds my description of his or her work inadequate or whose work I have accidentally omitted on this chapter.

It is obvious that amaranth seed surpasses traditional cereals in a number of nutritional and therapeutical values. Amaranth is considered as a millennium superfood with high nutraceutical values as it is used for several clinical/medical applications because it is a reasonably well-balanced food with functional properties that have been shown to provide clinical/medicinal benefits. Thanks to its properties, amaranth gives us a wide range of possibilities for using it in human nutrition, including active health support. Also it can be applied when we need more easily digestible quality proteins, e.g., in children, sportsmen, and the elderly. Further studies using more sophisticated and appropriate in vivo model systems are needed to draw solid conclusions on the subject of a nutritional functional value and therapeutic utilization of amaranth.

\section{Conflict of interests}

Authors declare that there is no conflict of interest. 


\section{Author details}

Manuel Soriano-García* and Isabel Saraid Aguirre-Díaz

Chemistry of Biomacromolecules Department, Chemistry Institute,

National Autonomous University of Mexico, Mexico City, Mexico

*Address all correspondence to: soriano@unam.mx

\section{IntechOpen}

(C) 2019 The Author(s). Licensee IntechOpen. This chapter is distributed under the terms of the Creative Commons Attribution License (http://creativecommons.org/licenses/ by/3.0), which permits unrestricted use, distribution, and reproduction in any medium, provided the original work is properly cited. (cc) BY 


\section{References}

[1] Rastogi A, Shukla S. Amaranth: A new millenium crop of nutraceutical values. Critical Reviews in Food Science and Nutrition. 2013;53(2):109-125. DOI: 10.1080/10408398.2010.517876

[2] Espitia-Rangel E. Breeding of grain amaranth. In: Paredes-Lopez O, editor. Amaranth. Biology, Chemistry and Technology. Boca Raton, USA: CRC Press; 1994. pp. 23-38

[3] National Academy Press. Amaranth: Modern Prospects for an Ancient Crop. Washington, DC: National Academic of Sciences; 1984

[4] Ulbricht C, Abrams T, Conquer J, Costa D, Grims-Serrano JM, Taylor S, et al. An evidence-based systematic review of amaranth (Amaranthus spp.) by the natural standard Research collaboration. Journal of Dietary Supplements. 2009;6(4):390-417. DOI: $10.3109 / 19390210903280348$

[5] Venskutonis PR, Kraujalis P. Nutritional components of amaranth seeds and vegetables: A review on composition, properties, and uses. Comprehensive Reviews in Food Science and Food Safety. 2013;12(4):381-412. DOI: $10.1111 / 1541-4337.12021$

[6] Jahaniaval F, Kakuda Y, Marcone MF. Fatty acid and triacylglycerol compositions of seed oils of five Amaranthus accessions and their comparison to other oils. Journal of the American Oil Chemists' Society. 2000;77(8):847-852. DOI: 10.1007/ s11746-000-0135-0

[7] USDA. Subset, Food, and All Foods. National Nutrient Database for Standard Reference, Amaranth grain. Release 28; 2016

[8] Kalinova J, Dadakova E. Rutin and total quercetin content in amaranth (Amaranthus spp.). Plant Foods for
Human Nutrition. 2009;64(1):68-74.

DOI: $10.1007 / \mathrm{s} 11130-008-0104-\mathrm{x}$

[9] Barba de la Rosa AP et al. Amaranth (Amaranthus hypochondriacus) as an alternative crop for sustainable food production: Phenolic acids and flavonoids with potential impact on its nutraceutical quality. Journal of Cereal Science. 2009;49:117-121. DOI: 10.1016/j.jcs.2008.07.012

[10] Gorinstein S et al. Comparison of composition and antioxidant capacity of some cereals and pseudocereals. International Journal of Food Science and Technology. 2008;43(4):629-637. DOI: 10.1111/j.1365-2621.2007.01498.x

[11] Klimczak I, Małecka M, Pachołek B. Antioxidant activity of ethanolic extracts of amaranth seeds. Food/ Nahrung. 2002;46(3):184-186. DOI: 10.1002/1521-3803(20020501) 46:3<184::AID-FOOD184>3.0.CO;2-H

[12] López VRL, Razzeto GS, Giménez MS, Escudero NL. Antioxidant properties of Amaranthus hypochondriacus seeds and their effect on the liver of alcohol-treated rats. Plant Foods for Human Nutrition. 2011;66(2):157-162. DOI: $10.1007 /$ s11130-011-0218-4

[13] Bejosano FP, Corke H. Protein quality evaluation of Amaranthus whole meal flours and protein concentrates. Journal of the Science of Food and Agriculture. 1998;76:100-106. DOI: 10.1002/ (SICI)1097-0010(199801)76:1<100::AIDJSFA931>3.0.CO;2-B

[14] Pisarikova B, Kracmar S, Herzig I. Amino acid contents and biological value protein in various amaranth species. Czech Journal of Animal Science. 2005;50(4):169174. DOI: $10.1002 /($ SICI)10970010(199801)76:1<100::AIDJSFA931>3.0.CO;2-B 
[15] Shukla S et al. Nutritional contents of different foliage cuttings of vegetable amaranth. Plant Food for Human Nutrition. 2003;58(3):1-8. DOI: 10.1023/B:QUAL.0000040338.33755.b5

[16] Kraujalis P, Venskutonis PR. Optimization of supercritical carbon dioxide extraction of amaranth seeds by response surface methodology and characterization of extracts isolated from different plant cultivars. Journal of Supercritical Fluids. 2013;73:80-86. DOI: 10.1016/j.supflu.2012.11.009

[17] Caselato-Sousa VM, Amaya-Farfán J. State of knowledge on Amaranth grain: A comprehensive review. Journal of Food Science. 2012;77(4):R93-R104. DOI: $10.1111 / j .1750-3841.2012 .02645 . \mathrm{x}$

[18] Stone LA, Lorenz K. The starch of Amaranthus: Physiochemical properties and functional characteristics. Starch. 1984;36(7):232-237. DOI: 10.1002/ star.19840360704

[19] Oleszek W, Junkuszew M, Stochmal A. Determination and toxicity of saponins from Amaranthus cruentus seeds. Journal of Agricultural and Food Chemistry. 1999;47(9):3685-3687. DOI: 10.1021/jf990182k

[20] Vasco Méndez NL, Soriano-García M, Moreno A, et al. Purification, crystallization and preliminary $\mathrm{X}$-ray characterization of a $36 \mathrm{kDa}$ Amaranth globulin. Journal of Agricultural and Food Chemistry. 1999;47(3):862-866. DOI: 10.1021/jf9809131

[21] Negro M, Giardina S, Marzani B, Marzatico F. Branched-chain amino acid supplementation does not enhance athletic performance but affects muscle recovery and the immune system. The Journal of Sports Medicine and Physical Fitness. 2008;48(3):347-351

[22] Montoya-Rodríguez A, de Mejía EG, Dia VP, et al. Extrusion improved the anti-inflammatory effect of amaranth
(Amaranthus hypochondriacus)

hydrolysates in LPS-induced human THP-1 macrophage-like and mouse RAW 264.7 macrophages by preventing activation of NF- $\mathrm{KB}$ signaling.

Molecular Nutrition \& Food Research. 2014;58(5):1028-1041. DOI: 10.1002/ mnfr.201300764

[23] Laparra JM, Haros M. Inclusion of ancient Latin-American crops in bread formulation improves intestinal iron absorption and modulates inflammatory markers. Food \& Function.

2016;7(2):1096-1102. DOI: 10.1039/ c5fo01197c

[24] Macdonald HM, New SA, Golden $\mathrm{MH}$, et al. Nutritional associations with bone loss during the menopausal transition: Evidence of a beneficial effect of calcium, alcohol, and fruit and vegetable nutrients and of a detrimental effect of fatty acids. The American Journal of Clinical Nutrition. 2004;79(1):155-165. DOI: $10.1093 /$ ajcn/79.1.155

[25] Levis S, Lagari VS. The role of diet in osteoporosis prevention and management. Current Osteoporosis Reports. 2012;10(4):296-302. DOI: 10.1007/s11914-012-0119-y

[26] Sacco SM, Horcajada MN, Offord E. Phytonutrients for bone health during ageing. British Journal of Clinical Pharmacology. 2013;75(3):697-707. DOI: 10.1111/bcp.12033

[27] Galan MG, Drago SR, Armada $\mathrm{M}$, José RG. Iron, zinc and calcium dialyzability from extruded product based on whole grain amaranth (Amaranthus caudatus and Amaranthus cruentus) and amaranth/Zea mays blends. International Journal of Food Sciences and Nutrition. 2013;64(4):502507. DOI: $10.3109 / 09637486.2012 .753038$

[28] A B et al. Cholesterol-lowering properties of amaranth grain and oil in hamsters. International 
Journal for Vitamin and Nutrition Research. 2003;73(1):39-47. DOI: 10.1024/0300-9831.73.1.39

[29] Mendonça S, Saldiva PH, Cruz RJ, Arêas JAG. Amaranth protein presents cholesterol-lowering effect. Food Chemistry. 2009;116:738-742. DOI: 10.1016/j.foodchem.2009.03.021

[30] Devaraj VC, Krishna BG. Gastric antisecretory and cytoprotective effects of leaf extracts of Amaranthus tricolor Linn in rats. Zhong Xi Yi Jie He Xue Bao. 2011;9:1031-1038. DOI: 10.3736/ jcim20110915

[31] Devaraj VC, Krishna BG. Antiulcer activity of a polyherbal formulation (PHF) from Indian medicinal plants. Chinese Journal of Natural Medicines. 2013;11(2):145-148. DOI: 10.1016/ S1875-5364(13)60041-2

[32] Cherkas A et al. Amaranth oil reduces accumulation of 4-hydroxynonenal-histidine adducts in gastric mucosa and improves heart rate variability in duodenal peptic ulcer patients undergoing Helicobacter pylori eradication. Free Radical Research. 2018;52(2):135-149. DOI: 10.1080/10715762.2017.1418981

[33] Kim HK, Kim MJ, Yon H, et al. Antioxidative and anti-diabetic effects of amaranth (Amaranthus esculantus) in streptozotocin-induced diabetic rats. Cell Biochemistry and Function. 2006;24(3):195-199. DOI: 10.1002/ cbf.1210

[34] Aschner JL, Aschner M. Nutritional aspects of manganese homeostasis. Molecular Aspects of Medicine. 2005;26(4-5):353-362. DOI: 10.1016/j. mam.2005.07.003

[35] Rucker D, Thadhani R, Tonelli M. Trace element status in hemodialysis patients. Seminars in Dialysis. 2010;23(4):389-395. DOI: 10.1111/j.1525-139X.2010.00746.x
[36] Koh ES, Kim SJ, Yoon HE, et al. Association of blood manganese level with diabetes and renal dysfunction: A cross-sectional study of the Korean general population. BMC Endocrine Disorders. 2014;14:24-32. DOI: 10.1186/1472-6823-14-24

[37] Lee SH, Jouihan HA, Cooksey RC, et al. Manganese supplementation protects against diet-induced diabetes in wild type mice by enhancing insulin secretion. Endocrinology. 2013;154(3):1029-1038. DOI: 10.1210/ en.2012-1445

[38] Miroshnichenko LA, Zoloedov VI, Volynkina AP, et al. Influence dietary therapy with use sunflower and amaranth oils on parameters of immune reactivity in patients with diabetes mellitus 2 type. Voprosy Pitaniia. 2009;78(4):30-36

[39] Yelisyeyeva O, Semen K, Zarkovic $\mathrm{N}$, et al. Activation of aerobic metabolism by Amaranth oil improves heart rate variability both in athletes and patients with type 2 diabetes mellitus. Archives of Physiology and Biochemistry. 2012;118(2):47-57. DOI: 10.3109/13813455.2012.659259

[40] Rahaie S, Gharibzahedi SM, Razavi $\mathrm{SH}$, et al. Recent developments on new formulations based on nutrient-dense ingredients for the production of healthy-functional bread: A review. Journal of Food Science and Technology. 2014;51(11):2896-2906. DOI: 10.1007/ s13197-012-0833-6

[41] Inglett G, Chen D, Liu S. Physical properties of gluten-free sugar cookies made from amaranth-oat composites. LWT--Food Science and Technology. 2015;63(1):214-220. DOI: 10.1016/j. lwt.2015.03.056

[42] Mansueto P, Seidita A, D’Alcamo A, et al. Non-celiac gluten sensitivity: Literature review. Journal of the American College of 
Nutrition. 2014;33(1):39-54. DOI: $10.1080 / 07315724.2014 .869996$

[43] Butterworth CE Jr, Tamura T. Folic acid safety and toxicity: A brief review. The American Journal of Clinical Nutrition. 1989;50:353-358. DOI: 10.1093/ajcn/50.2.353

[44] Feinleib $M$ et al. Folate fortification for the prevention of birth defects: Case study. American Journal of Epidemiology. 2001;154(12):S60-S69

[45] King DE, Mainous AG III, Lambourne CA. Trends in dietary fiber intake in the United States, 1999-2008. Journal of the Academy of Nutrition and Dietetics. 2012;112(5):642-648. DOI: 10.1016/j.jand.2012.01.019

[46] WHO (World Health Organization). Global Strategy On Diet, Physical Activity and Health. Geneva A57/9: WHO; 2004

[47] Peter K, Gandhi P. Rediscovering the therapeutic potential of Amaranthus species: A review. Egyptian Journal of Basic and Applied Sciences. 2017;4: 196-205. DOI: 10.1016/j.ejbas.2017.05.001

[48] Maiyo ZC, Ngure RM, Matasyoh JC, Chepkorir R. Phytochemical constituents and antimicrobial activity of leaf extracts of three Amaranthus plant species. African Journal of Biotechnology. 2010;9:3178-3182

[49] Sheeba AM, Deepthi SR, Mini

I. Evaluation of antimicrobial potential of an invasive weed Amaranthus spinosus L. In: Sabu A, Augustine A, editors. Prospects in Bioscience: Addressing the Issues. India: Springer; 2012:117-123

[50] Rivillas-Acevedo LA,

Soriano-García M. Isolation and biochemical characterization of an antifungal peptide from Amaranthus hypochondriacus seeds. Journal of Agricultural and Food Chemistry.
2007;55(25):10156-10161. DOI: 10.1021/ jf072069x

[51] Zeashan H, Amresh G, Singh S, Rao CV. Hepatoprotective and antioxidant activity of Amaranthus spinosus against $\mathrm{CCl} 4$ induced toxicity. Journal of Ethnopharmacology. 2009;125(2): 364-366. DOI: 10.1016/j.jep.2009.05.010

[52] Al-Dosari MS. The effectiveness of ethanolic extract of Amaranthus tricolor L.: A natural hepatoprotective agent. The American Journal of Chinese Medicine. 2010;38(6):1051-1064. DOI: 10.1142/S0192415X10008469

[53] Gandhi P, Khan Z, Niraj K. In vitro assay of anti-proliferative potential of Amaranthus cruentus aqueous extract on human peripheral blood lymphocytes. Current Trends in Biotechnology and Chemical Research. 2011;1:42-48. DOI: 10.1142/ S0192415X10008469

[54] Baskar AA, Al Numair KS, Alsaif $\mathrm{MA}$, Ignacimuthu S. In vitro antioxidant and antiproliferative potential of medicinal plants used in traditional Indian medicine to treat cancer. Redox Report. 2012;17:145-156. DOI: 10.1179/1351000212Y.0000000017

[55] Shiel WC Jr. Medical definition of malaria. Medicine Net. Visited April 30, 2019. Available from: https://www. medicinenet.com/script/main/art. asp?articlekey $=4255$

[56] Hiloua A, Nacoulmaa OGT, Guiguemdeb R. In vivo antimalarial activities of extracts from Amaranthus spinosus L. and Boerhaavia erecta L. in mice. Journal of Ethnopharmacology. 2006;103(2):236-240. DOI: 10.1016/j. jep.2005.08.006

[57] Adetutu A, Olorunnisola OS, Owoade AO, Adegbola P. Inhibition of in vivo growth of Plasmodium berghei by Launaea taraxacifolia and Amaranthus viridis in Mice. Malaria Research 
and Treatment. 2016;2016:9. DOI: $10.1155 / 2016 / 9248024$

[58] Ramírez-Medeles MC, Aguilar MB, Miguel RN, Bolaños-García VM, García-Hernández E, SorianoGarcía M. Amino acid sequence, biochemical characterization and comparative modeling of a nonspecific lipid transfer protein from Amaranthus hypochondriacus. Archives of Biochemistry and Biophysics. 2003;415(1):24-33. DOI: 10.1016/ S0003-9861(03)00201-7

[59] Mendoza-Figueroa JS, Kvarnheden A, Méndez-Lozano J, RodríguezNegrete EA, Arreguín-Espinosa de los Monteros R, Soriano-García M. A peptide derived from enzymatic digestion of globulins from amaranth shows strong affinity binding to the replication origin of Tomato yellow leaf curl virus reducing viral replication in Nicotiana benthamiana. Pesticide Biochemistry and Physiology. 2018;45:56-65. DOI: 10.1016/j. pestbp.2018.01.005

[60] Silva-Sánchez C et al. Bioactive peptides in amaranth (Amaranthus hypochondriacus) seed. Journal of Agricultural and Food Chemistry. 2008;56(4):1233-1240. DOI: 10.1021/ jf072911z

[61] Sabbione AC, Scilingo A, Añón MC. Potential antithrombotic activity detected in amaranth proteins and its hydrolyzates. LWT-Food Science and Technology. 2015;60(1):171-177. DOI:10.1016/j.lwt.2014.07.015

[62] Quiroga A, Barrio D, Añón MC. Amaranth lectin presents potential antitumor properties. LWT-

Food Science and Technology. 2015;60(1):478-485. DOI: $10.1016 / \mathrm{j}$. lwt.2014.07.035

[63] Fuentes Reyes M, ChávezServín JL, González-Coria C, et al. Comparative account of phenolics, antioxidant capacity, $\alpha$-tocopherol and anti-nutritional factors of amaranth (Amaranthus hypochondriacus) grown in the greenhouse and open field. International Journal of Agriculture and Biology. 2018;20(11):2428-2436. DOI: 10.17957/IJAB/15.0786 
Effect of Various Process Conditions on the Nutritional and Bioactive Compounds of Amaranth

\author{
Ofelia Marquez-Molina and Leticia Xochitl Lopez-Martinez
}

\begin{abstract}
Amaranth is a pseudocereal with unique nutritional and nutraceutical profiles. Typically, the amaranth grain is consumed after some process such as cooking in water, popping, or extrusion which has been mentioned to affect the nutritional and nutraceutical characteristics. In this chapter, we will analyze the changes in amaranth grain on bioactive compounds (total phenolic content) and nutritional and nutraceutical properties (antioxidant activities) subjected to different processes. It has been shown that phytochemical and nutritional contents of amaranth grain provide health benefits such as antioxidant activity, anti-allergic action, antianemic effect, anticancer activity, and antihypertensive effect, besides the capacity of decreasing plasma levels, stimulating the immune system, and reducing blood glucose levels.
\end{abstract}

Keywords: amaranth, bioactive compounds, nutritional components, processing

\title{
1. Introduction
}

Amaranthus is a genus (family Amaranthaceae) consisting of more than 50 species (some are considered weeds, and others are cultivated for use as vegetables, ornamentals, and cereals) [1] and is a pseudocereal that was domesticated in America over 4000 years ago by the Aztecs and Mayas [2, 3]. The importance of amaranth has resurged in the last years due to agricultural features, since it is a fast-growing cultivar with tolerance to drought conditions, can grow in poor soils, and has important nutritional properties $[4,5]$. Moreover, it has minerals, such as calcium, sodium, iron, magnesium, and vitamin E [6]. Polyphenolic compounds, such as phenolic acids and flavonoids, have been characterized in amaranth grains [7], which makes it an excellent source of bioactive compounds [8].

Typically, amaranth grain is not eaten raw and suffers a variety of processing methods in order to achieve desirable flavor, color, texture, and, sometimes, nutritional and nutraceutical properties. The different processing methods considered in this chapter such as cooking in water, toasting, fermentation, germination, or extrusion affect the nutritional and nutraceutical characteristics that have beneficial effects on human health [9-11]. 
The health benefits of amaranth come from nutrients and, in part, through the antioxidant characteristic of the phenolic compounds (non-nutrients) present in the grain, so that changes and variation in the composition and concentration of Nutrients and non-nutrients (such as the synthesis of phenolic compounds that may affect antioxidant activity) could indicate the type of amaranth grain processing that can preserve its nutritional and nutraceutical characteristics [8].

\section{The nutritional and bioactive value of amaranth seeds}

Amaranth seeds are rich in macronutrients such as proteins and have an outstanding balance of essential amino acids, as well as micronutrients including minerals $[12,13]$. Pseudocereals such as amaranth are commonly rich in minerals with high calcium $(\mathrm{Ca})$ content, potassium $(\mathrm{K})$, and sodium $(\mathrm{Na})$ are present in reasonable amounts, while zinc $(\mathrm{Zn})$, copper $(\mathrm{Cu})$, and manganese $(\mathrm{Mn})$ in moderate amounts $[14,15]$; more than $66 \%$ of total minerals were found in the bran and germ fractions in amaranth grain [16] and, in general, constitute rich source of iron (Fe), $\mathrm{Cu}, \mathrm{Mn}$, and $\mathrm{Zn}$ [13]. Based on the amino acid composition, amaranth seed protein is known to be of higher quality than most of the major cereal grains. The essential amino acid composition of amaranth grains from different Amaranthus species is summarized in Table 1. The lysine content is two to three times higher than that of the most common cereals, and sulfur amino acid content is also relatively high as compared with that of the most important legumes.

\begin{tabular}{|c|c|c|c|}
\hline Amino acid & A. caudatus & A. cruentus & A. hypochondriacus \\
\hline Aspartic acid & 83.0 & 83.7 & 83.4 \\
\hline Threonine & 41.7 & 45.8 & 49.3 \\
\hline Serine & 86.1 & 83.9 & ND \\
\hline Glutamic acid & 164 & 163.6 & ND \\
\hline Proline & 31.5 & 31.3 & ND \\
\hline Glycine & 77.3 & 70.0 & ND \\
\hline Alanine & 56.3 & 56.4 & ND \\
\hline Cysteine & 43.7 & 45.7 & ND \\
\hline Methionine & 18.4 & 15.9 & 16.6 \\
\hline Valine & 38.6 & 40.7 & 40.4 \\
\hline Isoleucine & 26.9 & 28.7 & 32.5 \\
\hline Leucine & 58.3 & 58.0 & 58.1 \\
\hline Tyrosine & 47.4 & 45.6 & 47.2 \\
\hline Phenylalanine & 43.2 & 44.4 & ND \\
\hline Tryptophane & 18 & 19.4 & ND \\
\hline Histidine & 31.2 & 30.6 & ND \\
\hline Lysine & 54.8 & 53.5 & 53.7 \\
\hline Arginine & 86.2 & 83.0 & ND \\
\hline
\end{tabular}

Table 1.

Content of amino acid profiles in $(\mathrm{g} / \mathrm{kg})$ of raw and processed amaranth varieties. 
Several studies were focused on polyphenols in various Amaranthus species, which resulted in the identification of several phenolic acids (benzoic acid, $\rho$-hydroxybenzoic acid, vanillic acid, gallic acid, coumaric acid, ferulic acid, caffeic acid, syringic acid, protocatechuic acid, p-OH-benzoic acid, and isoferulic acid), flavonoids (quercetin, kaempferol and myricetin, isorhamnetin, rhamnetin), and their glycosides (quercetin 3-rutinoside, quercetin 3-o-glucoside) [19, 20].

\section{The effect of processing on the nutritional and nutraceutical value in amaranth seeds}

\subsection{Cooking}

Pseudocereals are consumed after cooking. However, culinary methods can lead to considerable losses of soluble nutrients such as amino acids, phenolic compounds, and, namely, minerals.

The few studies about the effect of cooking on minerals in amaranth grains have reported a significant decrease in iron ( $\mathrm{Fe}$ ) content during the boiling, due to the wet procedures which in general cause loss of dry matter and Fe; however, the content of zinc $(\mathrm{Zn})$ was not affected. Roasting also reduced the content of this mineral but not the content of calcium (Ca) (Figure 1) [20]. The content of six amino acids increased after boiling and steaming compared with the raw seed (alanine, aspartic acid, glutamic acid, proline, tyrosine, and arginine).

Gamel et al. [21] investigated the effect of cooking on amaranth seeds of $A$. caudatus and $A$. cruentus. The seeds were washed with distilled water and then subjected to steam vapor in a closed water bath at normal pressure, until a soft texture was obtained. Steam reduced the content of phenolic compounds from 5.16 (raw) to $3.53 \mathrm{~g} / \mathrm{kg}$ (cooked) and 5.24 (raw) to $3.96 \mathrm{~g} / \mathrm{kg}$ (processed) in A. caudatus and A. cruentus, respectively.

Queiroz et al. [9] studied the effect of cooking on Amaranthus cruentus by immersing the grain in boiling water $\left(100^{\circ} \mathrm{C}\right)$ for 10 minutes. The processing reduced the mean total phenolic content in amaranth grain from 31.7 to $24.10 \mathrm{mg}$ of

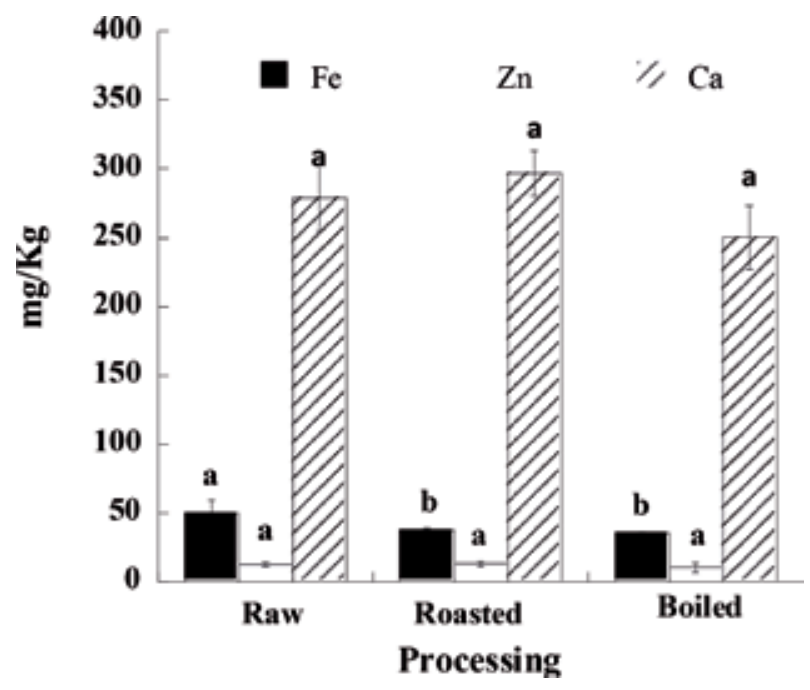

Figure 1.

Mineral composition of raw, roasted, and boiled Amaranthus (A. cruentus). 
gallic acid equivalent/g; however, the antioxidant activity measured by the inhibition of lipid oxidation using the $\beta$-carotene/linoleic acid system increased from $55.42 \%$ in raw seed to $79.52 \%$ in the cooked seed.

\subsection{Popping}

Popping or puffing is one of the most popular ways to process amaranth grains, which imparts a pleasant flavor to the final product. In popping, the heat causes vaporization of water contained in the starch matrix increasing the temperature and pressure and the successive swelling and expansion of starch granules; the endosperm is transformed into a bubbly matrix, which solidifies through the evaporation of water, yielding a spongy structure [22].

Popping significantly decreased Fe and Ca content (31 and 8\%, respectively). The decrease in Fe content could be attributed to the loss of pericarp during popping. Gamel et al. [18] reported that the levels of essential minerals (Mg, P, K, Ca, $\mathrm{Mn}, \mathrm{Fe}$, and $\mathrm{Cu}$ ) were not affected by popping; Pedersen et al. [7] reported similar behavior for the levels of $\mathrm{P}, \mathrm{Ca}, \mathrm{Fe}$, and $\mathrm{C}$; on the other hand, no significant effect was observed on $\mathrm{Zn}$ and $\mathrm{Mg}$ content due to popping. It was concluded that the outer layer of amaranth grain contained high amount of $\mathrm{Cu}$ and $\mathrm{Ca}$. In relation to the effect of processing on amino acids, Table 3 shows that the content of several amino acids is decreased as a consequence of the popping. The loss of tyrosine was the highest, followed by phenylalanine, cysteine, and lysine; in a different study, Amere et al. [23] reported that aromatic amino acids were strongly affected, phenylalanine and tyrosine completely vanished, $90 \%$ of tryptophan vanished during popping, and nonenzymatic browning reaction is the most probable explanation for the decrease in the level of amino acids during heat treatment [24].

By the phytochemical way, Queiroz et al. [9] studied the popping process in Amaranthus grain (A. cruentus); the processing reduced the value of total phenolic content from 31.7 to $22.71 \mathrm{mg} \mathrm{GAE} / \mathrm{g}$. A similar behavior was found by Muyonga et al. [25], they found that the total phenolic content in A. hypochondriacus and $A$. cruentus ranged from 3.34 and $3.63 \mathrm{mg} \mathrm{GAE} / \mathrm{g}$ from raw seeds, and popping altered the content of phenolics from 2.99 to $3.42 \mathrm{mg}$ GAE/g; however, no significant differences were observed between raw and popped grains. In contrast, popping increased the content of total flavonoids from 0.47 to $0.78 \mathrm{mg} \mathrm{GAE} / \mathrm{g}$ and 0.54 to $0.93 \mathrm{mg} \mathrm{GAE} / \mathrm{g}$ of $A$. hypochondriacus and A. cruentus, respectively. Heat has been reported to cause a reduction in total phenolic content of popped grain amaranth [26].

\subsection{Extrusion}

Extrusion cooking is a high-temperature and short-time process in which moistened, expansive, starchy, and/or proteinaceous food materials are plasticized and cooked in a tube by a combination of moisture, pressure, temperature, and mechanical shear, resulting in molecular transformation and chemical reaction [27] which are able to break the covalent bonds, denature undesirable enzymes, and inactivate some antinutritional factors such as tannins and phytates [28].

Chávez-Jauregui et al. [29] determined the amaranth amino acid composition after extrusion at different moisture and temperatures; the result showed that the extrusion process did not affect the content of aspartic acid, glutamic acid, glycine, and lysine.

Data about the effect of extrusion on the phenolic content of amaranth seeds is scarce; Repo-Carrasco-Valencia et al. [30] examined amaranth seeds for the levels of phenolic compounds during extrusion, and they found that the levels show a 
decrease up to $80.3 \%$ of kiwicha (Amaranthus caudatus). This decrease may be due to decarboxylation of phenolic acids during extrusion.

\subsection{Germination}

During germination, dried amaranth seed absorbs water, the embryonic axis lengthens, the seed breaks dormancy and then protection responses arise through the synthesis of phenolic compounds [31]. Germination can cause changes in nutrients as well as the elimination of antinutrients such as enzymatic inhibitors in seeds [10].

Gamel et al. [18] studied the effects of germination of Amaranthus caudatus and Amaranthus cruentus seeds, and they found that there was no difference in sodium $(\mathrm{Na})$, magnesium $(\mathrm{Mg})$, iron $(\mathrm{Fe})$, manganese $(\mathrm{Mn})$, and copper $(\mathrm{Cu})$ levels. However, calcium (Ca) (13 and 12\%) and zinc ( $\mathrm{Zn}$ ) (14.3 and 13.5) increased in both species. These findings may be attributed to a decomposition of phytate or tannins that bind those minerals by enzyme activity such as phytase.

In a similar study, Gamel et al. [32] showed that germination of Amaranthus caudatus and Amaranthus cruentus seeds increased the contents of amino acids, aspartic acid, serine, alanine, valine, leucine, and lysine, and decreased the contents of threonine, arginine, tyrosine, and phenylalanine in both species. The valine content showed the highest increase and the tyrosine content the highest reduction.

Several studies have found that germination can gradually accumulate soluble phenolics in germinating seeds and sprouts compared with raw seeds. However, several studies have also reported a decrease. This behavior may be associated with the results expressed as wet or dry weight considering that the water content during germination is gradually increased during the germination process and can also depend on the time and temperatures used to germinate the seeds [33, 34].

For example, Perales-Sánchez et al. [35] optimized the germination conditions of amaranth seeds that would maximize the total phenolic and flavonoid content. In raw amaranth grains, the value of free phenolic content was $12.14 \mathrm{GAE} / 100 \mathrm{~g}$, bound phenolic content $14.51 \mathrm{GAE} / 100 \mathrm{~g}$, and total phenolic content 26.65 GAE/100 g. The germination bioprocess increased free, bound, and total phenolic contents of amaranth seeds by 1103,600 , and $829 \%$, respectively, as in the case of total flavonoid contents whose content increases by $213 \%$, when compared with the unprocessed material; in the same study, the in vitro antioxidant activity was assessed using the oxygen radical absorbance capacity (ORAC) assay and the ABTS radical cation decolorization assay, and they reported that the antioxidant activity, evaluated by ORAC assay, increased by $300 \%$, while by ABTS method increased by $470 \%$ after germination.

Pasko et al. [36] studied the effect of sprouting on the content of total phenolic content of amaranth seed (A. cruentus Aztec and A. cruentus Rawa); the content of raw and sprout seed was from 2.95 to $250 \mathrm{mg} / \mathrm{g}$ and from 3.0 to $200 \mathrm{mg} / \mathrm{g}$, respectively. The antioxidant activity was determined in raw amaranth seed that showed values of 12.71 and $11.41 \mathrm{mmol}$ Trolox/ $\mathrm{kg}$ for ABTS and 4.42 and $3.15 \mathrm{mmol}$ Trolox/ $\mathrm{kg}$ for DPPH, sprouting increased antioxidant activity according to the ABTS (220 and $150 \mathrm{mmol}$ Trolox/ $\mathrm{kg}$ ) and to DPPH (149 and $250 \mathrm{mmol}$ Trolox/ $\mathrm{kg}$ ) for $A$. cruentus Aztec and A. cruentus Rawa, respectively.

Data about the effect of germination on the phytochemicals of amaranth is contradictory. Gamel et al. [18] examined the levels of phenolic compounds at different germination states of two varieties of Amaranthus; they found that germinated seeds, followed by drying at 30,60 , and $90^{\circ} \mathrm{C}$, decreased the contents of total phenolic compounds by $18.2,19.3$, and $33.7 \%$ in $A$. caudatus and $13.5,35.8$, and $41.1 \%$ in $A$. cruentus. They reported that drying the germinated seeds at high 
temperature $\left(60\right.$ or $\left.90^{\circ} \mathrm{C}\right)$ reduced their content of phenolic compounds compared with those dried at $30^{\circ} \mathrm{C}$.

\subsection{Fermentation}

Fermentation is a process that involves lactic acid bacteria with a wide array of applications and is used in amaranth grains to increase the nutritional quality and remove undesirable compounds. Depending on the $\mathrm{pH}$ and temperature conditions, a fermentation process may modify the content and compositions of bioactive compounds such as phenolic compounds [37].

Fermentation showed an increase in $\mathrm{Cu}$ and $\mathrm{Mg}$ but no significant change in $\mathrm{Zn}$ and Ca. Motta et al. [14] found that levels of $\mathrm{Fe}, \mathrm{Zn}$, and Ca were not affected by boiling or steaming; however, a decrease in $\mathrm{Mg}$ and $\mathrm{K}$ is shown (Table 2).

The effect of fermentation on free amino acid content from different pigmented Amaranthus grains was studied by Amere et al. [23]; the results of the study showed that almost all amino acids increased. Tyrosine, glutamic acid and proline remained unchanged while arginine strongly decreased. Lysine and phenylalanine increased to a greater extent than the rest of the other amino acids; an explication to this behavior could be the protein hydrolysis during fermentation due to the enzymatic activity [38, 39].

Alvarez-Jubete et al. [8] determined the influence of fermentation in total phenolic content and antioxidant capacity (DPPH and FRAP) of raw and fermented grains of Amaranthus; they found changes of concentration from 21.2 to $82.2 \mathrm{mgGAE} / 100 \mathrm{~g}$ in raw and fermented grain, respectively.

Antioxidant capacity (DPPH and FRAP) also increased following fermentation as a response of one of the many metabolic changes that take place on the seeds: the increase in the activity of the endogenous hydrolytic enzymes.

\subsection{Toasting}

Toasting is a rapid processing method that uses dry heat for short periods of time that improves texture, enhanced crispness and volume due to puffing, and improves color, flavor, and shelf life of amaranth grains.

Repo-Carrasco-Valencia [30] studied the effect of toasting of kiwicha (Amaranthus caudatus) on iron, zinc, and calcium. Iron was reduced after being

\begin{tabular}{lcccccccc}
\hline $\begin{array}{l}\text { Processing } \\
\text { method }\end{array}$ & Cu & Mn & Fe & Zn & Mg & Ca & K & \\
\hline Raw & Nd & Nd & 150.5 & 31.9 & 3111 & 1470 & Nd & Amere et al. \\
Popped & Nd & Nd & 106.7 & 32.4 & 3270 & 1350 & Nd & {$[23]$} \\
Fermented & Nd & Nd & 176.5 & 33.4 & 3330 & 1460 & Nd & \\
\hline Raw & 5.72 & 44.2 & 73.5 & 45.5 & 3280 & 2000 & 5520 & Motta et al. \\
Boiled & 6.52 & 45.6 & 74.2 & 47.0 & 3070 & 2007 & 5380 & {$[14]$} \\
Steamed & 6.01 & 43.8 & 72.5 & 46.8 & 3020 & 2005 & 5350 & \\
\hline Raw & 6.0 & 6.3 & 139 & 52.0 & 2220 & 1907 & 3268 & Mburu et al. \\
Cooked & 6.0 & 6.03 & 138 & 48.3 & 2219 & 1891 & 3244 & {$[15]$} \\
\hline Raw & 7.52 & 35.1 & 107 & 31.1 & $\mathrm{Nd}$ & $\mathrm{Nd}$ & $\mathrm{Nd}$ & Murakami \\
Popped & 8.7 & 37.8 & 114 & 33.8 & $\mathrm{Nd}$ & $\mathrm{Nd}$ & $\mathrm{Nd}$ & et al. [11] \\
\hline Nd, not determined. & & & & & & & & \\
\hline
\end{tabular}

Table 2.

Content of macro- and microelements $(\mathrm{mg} / \mathrm{kg})$ of raw and processed amaranth varieties. 
Effect of Various Process Conditions on the Nutritional and Bioactive Compounds of Amaranth DOI: http://dx.doi.org/10.5772/intechopen.88536

\begin{tabular}{lcccccc}
\hline Amino acid & \multicolumn{3}{c}{ Amaranthus caudatus } & \multicolumn{3}{c}{ Amaranthus cruentus } \\
\hline & Raw & Popped & Extruded & Raw & Boiled & Steamed \\
\hline Cysteine & 43.7 & 40.4 & 35.9 & 45 & 47 & 40 \\
\hline Aspartic acid & 83.0 & 93.7 & 96.7 & 89.9 & 109 & 107.8 \\
\hline Serine & 86.1 & 90.9 & 46.9 & 83.4 & 97.6 & 95.6 \\
\hline Glutamic acid & 164.0 & 170.6 & 185.3 & 217.6 & 249.7 & 253.1 \\
\hline Proline & 31.5 & 30.8 & 43.3 & 55.4 & 62.7 & 61.2 \\
\hline Glycine & 77.3 & 84.4 & 84.7 & 105.2 & 120.7 & 116.3 \\
\hline Alanine & 53.6 & 58.7 & 44.4 & 45.9 & 52.6 & 52.3 \\
\hline Valine & 38.6 & 42.4 & 49.3 & 40.7 & 40.7 & 42.1 \\
\hline Tyrosine & 47.4 & 34.8 & 32.7 & 39.8 & 44.9 & 46.4 \\
\hline Arginine & 82.6 & 77.6 & 82.4 & 122.2 & 143.5 & 137.4 \\
\hline & & Gamel et al. [18] & & & Motta et al. [17] &
\end{tabular}

Table 3.

Content of amino acids in $(\mathrm{g} / \mathrm{kg})$ of raw and processed amaranth varieties.

toasted from 5.0 to $3.55 \mathrm{mg} / 100 \mathrm{~g}$, but the content of calcium and zinc was not affected.

Raw amaranth grain is sometimes processed by toasting the raw grain at high temperatures before it is milled into flour. This process provides increased protein quality and digestibility as compared with the raw product. However, some studies show that lysine is partially inactivated by roasting, for example, Bressani et al. [40] evaluated the roasting process in the lysine content on Amaranthus cruentus and Amaranthus caudatus, and they found that the lysine content decreased by 3 and $18.9 \%$, respectively.

According to Queiroz et al. [9], toasting processes increased the content of total phenolic content from 1.35 to $20.3 \mathrm{mg}$ of gallic acid equivalent/g with respect to raw grain; even so, however, the antioxidant capacity measured by lipidic oxidation was determined by the system $\beta$-carotene/linoleic acid (55\%). On the other hand, Muyonga et al. [25] analyzed the effect of toasting on total phenolic content and total flavonoids of $A$. hypochondriacus and A. cruentus; no significant difference in total phenolic content was observed between raw and toasted grain for both varieties of amaranth. Nonetheless, heat treatment generally led to an increase in the flavonoid content in grain amaranth, and this behavior could be associated with deactivation of endogenous oxidative enzymes, preventing enzymatic oxidation which causes loss of the antioxidant compounds in the raw plant materials. Muyonga et al. [25] showed an increase of 47.1 and $62.3 \%$ in A. hypochondriacus and A. cruentus, respectively.

Toasting resulted in a significant increase in antioxidant activity of both $A$. hypochondriacus (42.8\%) and A. cruentus (62.3\%); the antioxidant activity of plant materials is attributable to flavonoids and other phenolic compounds [41, 42]. Therefore, the increase in antioxidant activity might be due to the observed increase in total flavonoids.

In summary, amaranth grains are very rich in nutrients and non-nutrients such as total phenolic compounds and total flavonoids important for a diet with beneficial effects on human health. To consume amaranth it is necessary to be subjected to various processes to make it more palatable, without affecting or affecting as little as possible its nutritional content and bioactive compounds; the data indicated how 
different processing methods affect the mineral, amino acid, and phenolic content. With this information, it is possible to choose the best procedure to process amaranth in order to preserve or improve their nutritional and nutraceutical quality.

\section{Conclusion}

Processing resulted in important changes, on the minerals, amino acid, and phenolic content of amaranth seed.

A general decrease in the concentration of soluble compounds ( $\mathrm{Fe}, \mathrm{Zn}$, and phenolic compounds) was observed in cooking (boiling and steaming), but it does not affect the amino acid content, which is affected by popping. In the case of total phenolics, toasting, fermentation, and germination showed a positive effect on its content; similar behavior was found for total flavonoids during popping. Regarding the antioxidant activity, it was not affected by the roasting process and increases during the steam treatment in relation to the raw amaranth grain. Germination exerts a positive effect on the content of minerals and total phenolic compounds. The insoluble fractions of amaranth grain have been less studied and need further investigation.

Amaranth seeds constitute an important food because of their nutritional characteristics. They are also a good source of minor compounds that are responsible for their different biological activities. Nonetheless, the proven health effects of raw amaranth grains, cooking, popping, fermentation, germination, and amaranthbased products have yet to be studied, and more in vitro and in vivo research is needed.

\section{Conflict of interest}

The authors declare no conflict of interest.

\section{Author details}

Ofelia Marquez-Molina ${ }^{1}$ and Leticia Xochitl Lopez-Martinez ${ }^{2 *}$

1 University Center of UAEM Amecameca, University Autonomous State of Mexico, State of Mexico, Mexico

2 CONACYT-Research Center for Food and Development, Hermosillo, Sonora, Mexico

*Address all correspondence to: leticia.lopez@ciad.mx

IntechOpen

(C) 2019 The Author(s). Licensee IntechOpen. This chapter is distributed under the terms of the Creative Commons Attribution License (http://creativecommons.org/licenses/ by/3.0), which permits unrestricted use, distribution, and reproduction in any medium, provided the original work is properly cited. (cc) BY 


\section{References}

[1] Arendt-Elke K, Amaranth ZE. Cereal grains for the food and beverage industries. In: Food Science Technology and Nutrition. Vol. 248. Oxford Cambridge, Philadelphia: Woodhead Publishing Limited; 2013. pp. 439-473

[2] Lopez-Mejía OA, López-Malo A. Palou. Antioxidant capacity of extracts from amaranth (Amaranthus hypochondriacus L.) seeds or leaves. Industrial Crops and Products. 2014;53:55-59

[3] Milán-Carrillo J, Montoya-Rodríguez A, Reyes-Moreno, C. High antioxidant capacity beverages based on extruded and roasted amaranth (Amaranthus hypochondriacus) flour. In Hispanic Foods: Chemistry and Bioactive Compounds, 1st ed. Tunick, MH, González de Mejía, editors. Washington D.C.: American Chemical Society. 2012. p. 199-216. DOI:10.1021/bk-2012-1109.ch013

[4] Khandaker L, Masum-Akond ASMG, Ali MB, Oba S. Biomass yield and accumulations of bioactive compounds in red amaranth (Amaranthus tricolor L.) grown under different colored shade polyethylene in spring season. Scientia Horticulturae. 2010;123:289-294

[5] Avanza MV, Puppo MC, Añón MC. Structural characterization of amaranth protein gels. J. Food Science. 2005;70:223-229

[6] Yánez E, Zacarías I, Granger D, Vásquez M, Estévez AM. Chemical and nutritional characterization of amaranthus (Amaranthus cruentus L). Archivos Latinoamericanos de Nutrición. 1994;44:57-62

[7] Pedersen HA, Steffensen SK, Christophersen C, Mortensen AG, Jorgensen LN, Niveyro S, et al. Synthesis and quantitation of six phenolic amides in Amaranthus spp. Journal of Agricultural and Food Chemistry. 2010;58:6306-6631

[8] Alvarez-Jubete L, Wijngaard H, Arendt EK, Gallagher E. Polyphenol composition and in vitro antioxidant activity of amaranth, quinoa buckwheat and wheat as affected by sprouting and baking. Food Chemistry. 2010;119:770-778

[9] Queiroz YSD, Soares RAM, Capriles VD, Torres EAFDS, áreas JAG. Efeito do processamento na atividade antioxidante do frao de amaranto (Amaranthus cruentus L, BRSaLEFRIA). Archivos Latinoamericanos de Nutrición. 2009;59:419-424

[10] López-Martínez LX, Leyva-López N, Gutiérrez-Grijalva EP, Heredia JB. Effect of cooking and germination on bioactive compounds in pulses and their health benefits. Journal of Functional Foods. 2017;38:624-634

[11] Murakami T, Yutani A, Yumano T, Iyota $\mathrm{H}$, Konishi $\mathrm{H}$. Effects of popping on nutrient contents of amaranth seeds. Plant Food for Human Nutrition. 2014;69:25-29

[12] Thanapornpoonpong SN, Vearasilp S, Pawelzik E, Gorinstein S. Influence of various nitrogen applications on protein and amino acids profiles of amaranth and quinoa. Journal of Agricultural and Food Chemistry. 2008;56:11464-11470

[13] Mota C, Santos M, Mauro R, Samman N, Matos AS, Torres D, et al. Protein content and amino acids profile of pseudocereals. Food Chemistry. 2016;193:55-61

[14] Motta C, Nascimiento AC, Santos M, Delgado I, Coelho I, Rego A, et al. The effect of cooking methods on the mineral content of quinoa 
(Chenopodium quinoa), amaranth (Amaranthus sp.) and buckwheat (Fagopyrum esculentum). Journal of Food Composition and Analysis. 2016;49:57-64

[15] Mburu MW, Gikonyo NK, Kenji GM, Mwasaru A. Properties of a complementary food based on amaranth grain (Amaranthus cruentus) grown in Kenya. Journal of the Science of Food and Agriculture. 2011;1:153-178

[16] Berghofer E, Schoenlechener R. In Grain amaranth pseudocereals and less common cereals: Grain properties and utilization potential. Belton PS, Taylor JRN editors. Germany, Berlin Heidelberg: Springer Verlag. pp. 219-260

[17] Motta C, Castanheira I, Gonzales GB, Delgado I, Torres D, Santos M, et al. Impact of cooking methods and malting on amino acids content in amaranth, buckwheat and quinoa. Journal of Food Composition and Analysis. 2019;76:58-65

[18] Gamel TH, Linssen JP, Alink GM, Mosallem AS, Shekib LA. Nutritional study of raw and popped seed proteins of Amaranthus caudatus L. and Amaranthus cruentus L. Journal of the Science of Food and Agriculture. 2004;84:1153-1158

[19] Venskutonis PR, Kraujalis P. Nutritional components of amaranth seeds and vegetables: A review on composition, properties, and uses. Comprehensive Reviews in Food Science and Food Safety. 2013;12:381-412

[20] Repo-Carrasco-Valencia R, Helström JK, Pihlava JM, Mattila PH. Flavonoids and other phenolic compounds in Andean indigenous grains: Quinoa (Chenopodium quinoa), kañiwa (Chenopodium pallidicaule) and kiwicha (Amaranthus caudatus). Food Chemistry. 2010;120:128-133
[21] Gamel TH, Linssen JP, Mesallam AS, Damir AA, Shekib LA. Seed treatments affect functional and antinutritional properties of amaranth flours. Journal of the Science of Food and Agriculture. 2006;86:1095-1102

[22] Lara N, Raudales J. Popping of amaranth grain (Amaranthus caudatus) and its effect on the functional, nutritional and sensory properties. Journal of the Science of Food and Agriculture. 2002;82:797-805

[23] Amere E, Mouquet-River C, Servent A, Morel G, Adish A, Haku GD. Protein quality of amaranth grains cultivated in Ethiopia as affected by popping and fermentation. Food and Nutrition Sciences. 2015;6:38

[24] Tovar LR, Brito E, Takahashi T, Miyazawa T, Soriano J, Fujimoto K. Dry heat popping of Amaranth seed might damage some of its essential amino acids. Plant Foods for Human Nutrition. 1989;39:299-309

[25] Muyonga JH, Andabati B, Ssepuuya G. Effect of heat processing on selected grain amaranth physicochemical properties. Food Science \& Nutrition. 2014;2:9-16

[26] Yanez GAJK, Walker MCE, Raphow JH. Amaranthus hypochondriacus: Starch isolation and partial characterization. Cereal Chemistry. 1986;63:273-276

[27] Castells M, Marin S, Sanchis V, Ramos AJ. Fate of mycotoxins in cereals during extrusion cooking: A review. Food Additives and Contaminants. 2005;22:150-157

[28] Fellows PJ. Food Processing Technology: Principles and Practice. 3rd edition. Cambridge, England: Woodhead Publishing Ltd; 2009. pp. 177-182 
[29] Chávez-Jauregui RN, Silva MEMP, Aréas JAG. Extrusion cooking process for amaranth (Amaranthus caudatus L). Journal of Food Science;65(6):1009-1015

[30] Repo-Carrasco-Valencia R, de La Cruz AA, Alvarez JCI, Kallio H. Chemical and functional characterization of kaniwa (Chenopodium pallidicaule) grain, extrudate and bran. Plant Food for Human Nutrition. 2009;64:94-101

[31] Repo-Carrasco-Valencia R, Peña J, Kallio H, Salminen S. Dietary fiber and other functional components in two varieties of crude and extruded kiwicha (Amaranthus caudatus). Journal of Cereal Science. 2009;49:219-224

[32] Gamel TH, Linseen JP, Mesallem AS, Damir AA, Shekib LA. Effect of seed treatments on the chemical composition and properties of two amaranth species: Starch and protein. Journal of the Science of Food and Agriculture. 2005;319:327

[33] Mbithi S, Van Camp J, Rodríguez R, Huygheabaert A. Effects of sprouting on nutrient and antinutrient composition of kidney beans (Phaseolus vulgaris var rose coco). European Food Research and Technology. 2001;212:188-191

[34] Guo X, Li T, Tang K, Liu RH. Effect of germination on phytochemical profiles and antioxidant activity on mung bean sprouts (Vigna radiata). Journal of Agricultural and Food Chemistry. 2012;60:11050-11055

[35] Perales-Sánchez JC, Reyes-Moreno C, Gómez-Favela MA, Milán-Carrillo J, Cuevas-Rodríguez EO, Valdez Ortiz A, et al. Increasing the antioxidant activity, total phenolic and flavonoids contents by optimizing the germination conditions of amaranth seeds. Plant Food for Human Nutrition. 2014;69:196-202
[36] Pasko P, Barton H, Zagrodzki P, Gorinstein S, Folta M, Zachwieja Z. Anthocyanins, total polyphenols and antioxidant activity in amaranth and quinoa seeds and sprouts during their growth. Food Chemistry. 2009;115:994-998

[37] Nufer KR, Ismail B, Hayes KD. The effects of processing and extraction conditions on content, profile and stability of isoflavones in a soymilk system. Journal of Agricultural and Food Chemistry. 2009;57(4):1213-1218

[38] Sripriya G, Antony U, Chandra TS. Changes in carbohydrate, free amino acids, organic acids, Phytate and $\mathrm{HCl}$ extractability of minerals during germination and fermentation of finger millet (Eleusine coracana). Food Chemistry. 1997;58:345-350

[39] Pranoto Y, Anggrahini S, Efendi Z. Effect of natural and lactobacillus plantarum fermentation on In vitro protein and starch Digestibilities of sorghum flour. Food Bioscience. 2013;2:46-52

[40] Bressani R, Sánchez-Marroquín A, Morales E. Chemical composition of grain amaranth cultivars and effects of processing on their nutritional quality. Food Reviews International. 1992;8:23-49

[41] Kähkönen MO, Hopia AI, Vuorela HJ, Rauha JP, Pihlaja K, Kujala TS, et al. Antioxidant activity of plant extracts containing phenolic compounds. Journal of Agricultural and Food Chemistry. 1999;47(10):3954-3962

[42] Lopez-Martinez LX, Oliart-Ros RM, Valerio-Alfaro G, Lee CH, Parkin KL, Garcia HS. Antioxidant activity, phenolic compounds and anthocyanins content of eighteen strains of Mexican maize. LWT- Food Science and Technology. 2009;42(6):1187-1192 

Section 3

Amaranth Oil 



\title{
Amaranth Seed Oil Composition
}

\author{
Parisa Nasirpour-Tabrizi, Sodeif Azadmard-Damirchi, \\ Javad Hesari and Zahra Piravi-Vanak
}

\begin{abstract}
In this chapter, amaranth seed oil composition will be presented. The main component of this oil is triacylglycerols (TAGs). TAGs are composed of fatty acids, which have an important effect on oil stability, application, and nutritional properties. POL, PLL, POO, OLL, and LOO are the predominant TAGs in the amaranth seed oil. Linoleic acid (C18:2), oleic acid (C18:1), and palmitic acid (C16:0) are the predominant fatty acids present in the amaranth oil. Minor components of this oil are squalene, sterols, tocopherols, carotenoids, phospholipids, etc. Growth conditions of amaranth and extraction conditions can influence oil composition, which will be discussed in this chapter as well. Oil stability and quality parameters will be also discussed. The stability of this oil during different conditions of storage will be a part of this chapter.
\end{abstract}

Keywords: triacylglycerol, fatty acid, squalene, tocopherol, sterol

\section{Introduction}

Grain amaranth is considered as a gluten-free pseudocereal, which is a non-grass but cereal-like grain (true cereals are classified as grasses). It is suitable to be used as the celiac disease patient diet as it contains no gluten [1]. Among more than 60 species, the grain of Amaranthus caudatus, Amaranthus hypochondriacus, Amaranthus cruentus, Amaranthus hybridus, and Amaranthus mantegazzianus can be used as flour in some industries, such as bakery and confectionery. However, species of Amaranthus retroflexus, Amaranthus viridis, and Amaranthus spinosus are not safe to be consumed [2].

The amaranth grain is mainly composed of about $61.3-76.5 \%$ carbohydrate (mostly starch), 13.1-21.5\% crude protein, 5.6-10.9\% crude fat, $2.7-5 \%$ crude fiber, and 2.5-4.4\% ash [3]. Proteins and lipids are two nutritiously important macromolecules of the amaranth grain. The content and even the quality of these two macronutrients are different from those with cereals. The amaranth grain has higher protein content in comparison to cereals. Lysine, which is the limiting amino acid in cereals, is found in higher amounts in amaranth grain. The high protein content of the amaranth grain is also evident from its high essential amino acid index $(\mathrm{EAAI}=90.4 \%)$, which makes it comparable with egg protein [4].

In addition to protein content and special amino acid profile, amaranth grain usually contains 5-8\% fat, which is important from the nutritional aspect [5]. However, spinosus and tenuifolius species can contain oil content as much as 17 and $19.3 \%$, respectively. The fat content of the amaranth grain is dependent on the species, cultivars, and also accessions [6]. 
The fat content of amaranth grain is two to three times higher than cereals [7]. The oil is usually extracted from the grain by the solvent extraction method with the help of a non-polar organic solvent in a Soxhlet apparatus [8]. Supercritical carbon dioxide can be used as an alternative to traditional organic solvents for the extraction of the oil (supercritical fluid extraction method) $[9,10]$. In the accelerated solvent extraction method, high pressure and temperature (even above the boiling point of the organic solvent) are used [6]. The oil yield with the Soxhlet method (62.1-75.7\%) and accelerated solvent extraction method (65.1-78.1\%) is almost similar; however, the latter is faster and uses lower organic solvent. The supercritical fluid extraction method has the lowest oil yield among the three methods (54.6-61.1\%) [8].

Lipid fraction is mainly composed of triacylglycerols (TAGs) as the major component (around 80\%) and other minor compounds, such as squalene, sterols, tocopherols, carotenoids, phospholipids, etc. [11]. Lipid fraction can also be divided into two groups: free lipids and bonded lipids. TAGs are the major free lipids, while phospholipids (up to $10.2 \%$ of total lipids) and glycolipids (6.4\% of total lipid fraction) comprise the main part of the bounded lipids [11].

\section{Triacylglycerol profile}

TAGs are the major component of the amaranth oil, comprising $78-82 \%$ of the lipid fraction $[11,12]$. Di- and monoacylglycerols comprise $5.1-6.5$ and 3-3.5\% of lipid fraction, respectively [11]. They are composed of fatty acids. Although the oxidative stability and the nutritional value of the oil are determined by the fatty acid profile, the functionality of oil is affected by the type and amount of TAGs [13]. The predominant structures in the amaranth oil are diunsaturated TAGs (UUS; 43.4-50.2\%) and triunsaturated TAGs (UUU; 33-35.7\%) [13].

The major TAG composition of Amaranthus cruentus is presented in Table 1. POL, PLL, POO, OLL, and LOO are dominant TAGs in the amaranth oil with carbon number ranging between 50 and 54 [7, 11, 13]. According to the TAG profile,

\begin{tabular}{cccc}
\hline & Reference no. [7] & Reference no. [13] & Reference no. [11] \\
\hline LLL & 4 & 5.94 & Not reported \\
\hline OLL & 12.1 & $10.97^{\mathrm{a}}$ & 2.4 \\
\hline PLL & 13.8 & $14.48^{\mathrm{b}}$ & $16.7^{\mathrm{b}}$ \\
\hline LOO & 11.8 & $10.95^{\mathrm{c}}$ & 2.6 \\
\hline POL & $20^{\mathrm{d}}$ & 16.69 & 25.4 \\
\hline PPL & 7.5 & 7.01 & 22.6 \\
\hline OOO & 7.9 & $4.82^{\mathrm{e}}$ & 3.6 \\
\hline POO & $12.5^{\mathrm{f}}$ & $11.8^{\mathrm{g}}$ & 16.7 \\
\hline
\end{tabular}

$M$, myristic acid; $P$, palmitic acid; $P$, palmitoleic acid; $S$, stearic acid; $O$, oleic acid; $L$, linoleic acid;

Ln, linolenic acid.

${ }^{a} O L L+O O L n$

${ }^{b} P L L+P L n O$

${ }^{c} \mathrm{LOO}+\mathrm{PoOO}$

${ }^{d} P O L+S L L$

${ }^{e} \mathrm{OOO}+\mathrm{MSO}$

${ }^{f} \mathrm{POO}+\mathrm{SOL}$

${ }^{g} \mathrm{POO}+\mathrm{PSL}$.

Table 1.

Major triacylglycerol composition of the oil from Amaranthus cruentus. 
amaranth oil is similar to corn and cottonseed oils [7,14]. Like other vegetable oils, unsaturated fatty acids generally occupy the sn-2 position in the TAG structure of the amaranth grain oil. Linoleic acid and oleic acid are the two predominant fatty acids occupying the sn-2 position in the TAG structure of the amaranth grain oil, with percentages of 61.3 and 35.5, respectively, resembling cereals and also cottonseed and sesame seed oils [7]. Germination of the grain causes a decrease in TAG content as a result of increasing the lipase activity. Heat treatment of the grain, such as popping and cooking, decreases the TAG content [11].

\section{Fatty acid composition}

The fatty acid composition of the oil gives information about oxidative stability and nutritional quality. Table 2 presents the fatty acid profile of some species of Amaranthus grain. Investigation on 104 genotypes from 30 species of Amaranthus grain revealed that palmitic acid, oleic acid, and linoleic acid were predominant in the oil with average percentages of $21.3,28.2$, and 46.5 , respectively. Other fatty acids such as stearic and linolenic are also present in the oil, but in minor amounts [15]. The oil is highly unsaturated, containing more than $70 \%$ unsaturated fatty acids. The ratio of saturated to unsaturated fatty acids ranges between 0.26 and 0.32 [16]. The fatty acid profile of the amaranth oil is similar to that of cottonseed, buckwheat, and corn oils $[13,14]$.

\begin{tabular}{lccccc}
\hline & C16 & C18:0 & C18:1 & C18:2 & Source \\
\hline A. cruentus & $15.8-27$ & Tr-4.2 & $20.3-38.9$ & $33.6-47$ & {$[7,13,15-19]$} \\
\hline A. caudatus & $12.3-20.5$ & $2.2-4.7$ & $23.8-32.9$ & $35.6-49.8$ & {$[11,18,20]$} \\
\hline A. hypochondriacus & $17.9-24$ & $0.9-3.7$ & $16.3-33.7$ & $38.9-52.5$ & {$[13,15,16,18]$} \\
\hline A. hybridus & $18.6-22$ & $1.3-4.4$ & $18.7-26.3$ & $47.4-55.9$ & {$[12,15,16,18]$} \\
\hline A. tricolor & $19.5-24.3$ & $1-3.6$ & $25.9-27.5$ & $46.4-51.5$ & {$[15,16,21]$} \\
\hline A. dubius & $15.7-25.9$ & $0.7-4.1$ & $14.8-30.5$ & $46.9-53.5$ & {$[15,18,21]$} \\
\hline Tr, trace. & & & & &
\end{tabular}

Table 2.

Fatty acid composition of Amaranthus species grain oil.

\section{Squalene}

Squalene is a triterpene $\left(\mathrm{C}_{30} \mathrm{H}_{50}\right)$ with six double bonds at carbon numbers $2,6,10,14,18$, and 22 , which is present in the unsaponifiable fraction of the oil (Figure 1). It is an intermediate molecule for the biosynthesis of phytosterols and cholesterol [22]. The main sources of squalene are whale and shark liver oil (40$86 \%$ ). However, due to the concerns about the extinction of these marine animals, attempts are made to replace the animal source of squalene with a plant one [23].

Vegetable oils can be used as dietary sources of squalene. There is about $0.5 \%$ squalene in olive oil; around $0.03 \%$ in corn, hazelnut, and peanut oils; and $0.01 \%$ in grape seed and soybean oils [24]. The deodorizer distillates of oils such as olive oil, soybean oil, and palm fatty acids have higher amounts of squalene, containing $10-30,1.8-3.5$, and $0.2-1.3 \%$, respectively [25].

Amaranth grain is another natural plant source of squalene. Although amaranth grain has lower oil content compared to the other oil-containing seeds, its oil fraction is a rich source of squalene [26] (Table 3). The high content of squalene in 
the amaranth grain oil makes it a unique component, which can be used to recover squalene. Although the direct derivation of squalene from amaranth seed is not economically affordable, the recovery of squalene from amaranth oil as a coproduct of starch production is advantageous [26]. An extensive study on 104 genotypes from 30 species of Amaranthus grain revealed the squalene concentration in the oil fraction was trace, $7.3 \%$ with an average of $4.2 \%$ [15]. The total content of squalene is dependent on the method of oil extraction. It has been demonstrated that the oil extracted with supercritical $\mathrm{CO}_{2}$ had the highest squalene concentration (about $7 \%)$, followed by oil extracted by chloroform: methanol (2: $1 \mathrm{v} / \mathrm{v} ; 6 \%)$ and coldpressed oil (5.7\%) [27]. However, in another investigation, it has been shown that squalene yield is the highest by accelerated solvent extraction method (4.4-4.7\%), followed by Soxhlet (3.8-4.2\%) and supercritical fluid extraction (3.3-3.8\%) methods, respectively [8]. It should be mentioned that heat treatments such as cooking and popping the seeds cause an increase in the squalene concentration in the lipid fraction [11].

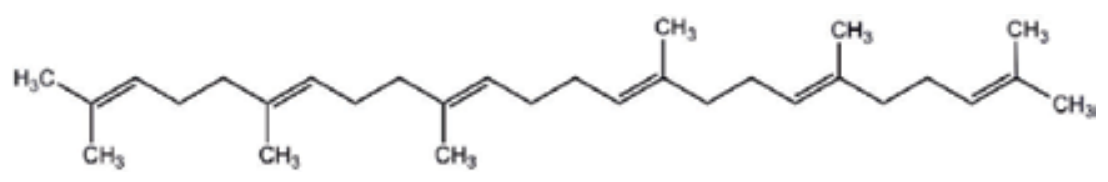

Figure 1.

Structure of squalene.

\begin{tabular}{|c|c|c|}
\hline Amaranthus species & \% Squalene & Reference \\
\hline \multirow[t]{9}{*}{ A. cruentus } & 6.56 & [7] \\
\hline & 4.9 & [11] \\
\hline & $5.74-6.95$ & [27] \\
\hline & $2.26-5.94$ & [17] \\
\hline & $4.2-5.44$ & [16] \\
\hline & $3.32-4.93$ & [15] \\
\hline & 9.16 & [13] \\
\hline & 6.96 & [14] \\
\hline & $5.29-6.25$ & {$[28]$} \\
\hline \multirow[t]{4}{*}{ A. hypochondriacus } & $4.74-6.98$ & {$[15]$} \\
\hline & $3.62-5.01$ & {$[16]$} \\
\hline & 9.96 & [13] \\
\hline & $6.05-7.12$ & {$[28]$} \\
\hline \multirow[t]{2}{*}{ A. hybridus } & 5.23 & [16] \\
\hline & $2.26-7.3$ & {$[15]$} \\
\hline \multirow[t]{2}{*}{ A. caudatus } & $0.67-8.19$ & [20] \\
\hline & 4.8 & {$[11]$} \\
\hline \multirow[t]{2}{*}{ A. tricolor } & $4.73-5.75$ & [15] \\
\hline & 6.14 & {$[16]$} \\
\hline A. dubius & $2.72-5.63$ & [15] \\
\hline
\end{tabular}

Table 3.

Squalene content of different species of Amaranthus grain oil. 


\section{Phytosterols}

Plant sterols (phytosterols) are minor components of the vegetable oils, which comprise a large proportion of unsaponifiable fraction. They contribute to oxidative stability and extended shelf-life and have serum cholesterol-lowering properties $[29,30]$. Phytosterols are found as 4-desmethysterols, 4-monomethylsterols, and 4, 4'-dimethylsterols. They can also be classified as free and esterified forms [31]. It has been reported that a large proportion of the phytosterols in amaranth oil are in esterified form and only low amounts are present in the free form (about 20\%) [7]. However, in most of the vegetable oils, such as soybean, sesame, olive, cottonseed, safflower, palm and coconut oils, free sterols comprise the predominant form (54-85\%) [32].

Total phytosterol content of the amaranth oil is between 1931 and $2762 \mathrm{mg} / 100 \mathrm{~g}$ oil [7, 21, 27, 33]. This level of phytosterol in amaranth oil is much higher than values established by Codex Alimentarius for most of common vegetable oils, such as coconut oil (40-120 mg/100 g), cottonseed oil (270-640 mg/100 g), flaxseed oil (230-690 mg/100 g), palm oil (30-70 mg/100 g), low-erucic acid

\begin{tabular}{|c|c|c|c|c|c|c|c|c|}
\hline & \multicolumn{6}{|c|}{ A. cruentus } & \multirow{2}{*}{$\begin{array}{c}\text { A. } \\
\text { dubius }\end{array}$} & \multirow{2}{*}{$\begin{array}{c}\text { A. } \\
\text { tricolor }\end{array}$} \\
\hline & I & II & III & IV & V & VI & & \\
\hline Cholesterol & $\operatorname{Tr}$ & 0.01 & 0.01 & - & - & - & - & - \\
\hline $\begin{array}{l}\text { 24-Methylene } \\
\text { cholesterol }\end{array}$ & 0.3 & 0.42 & 0.25 & 1.64 & 1.54 & 1.41 & - & - \\
\hline Campesterol & 1.6 & 0.76 & 1 & 1.83 & 1.96 & 1.96 & 2.61 & 1.57 \\
\hline Stigmasterol & 0.9 & 0.77 & 0.44 & 1.28 & 1.08 & 1.49 & 20.09 & 13.7 \\
\hline$\Delta^{7}$-Ergostenol & - & 23.8 & 25.3 & - & - & - & - & - \\
\hline$\alpha$-Spinasterol & - & $34.2^{\mathrm{a}}$ & $26.3^{\mathrm{a}}$ & $44.94^{\mathrm{b}}$ & $53.24^{\mathrm{b}}$ & $56.31^{\mathrm{b}}$ & - & - \\
\hline Sitostanol & $\operatorname{Tr}$ & 0.25 & 0.18 & 1.18 & 1.35 & 1.09 & - & - \\
\hline$\Delta^{7}$-Campesterol & 24.8 & - & - & - & - & - & 31.19 & 24.35 \\
\hline Clerosterol & 42 & - & - & - & - & - & 1.58 & 3.71 \\
\hline Sitosterol & 1.3 & - & - & - & - & - & 2 & 1.74 \\
\hline$\Delta^{5}$-Avenasterol & 2 & 1.68 & 2.34 & 0.79 & 0.74 & 0.35 & 24.27 & 30.76 \\
\hline$\Delta^{5,24}$-Stigmastadienol & $\operatorname{Tr}$ & 1.89 & 2.26 & 1.92 & 2.04 & 1.45 & 13.66 & 10.73 \\
\hline$\Delta^{7}$-Stigmastenol & 15.2 & 22.2 & 24.4 & 15.02 & 14.48 & 11.74 & 0.69 & 1.52 \\
\hline$\Delta^{7}$-Avenasterol & 11.9 & 13.4 & 14.9 & 8.56 & 7.27 & 8.09 & 0.15 & 6.11 \\
\hline$\Delta^{7}$-Ergosterol & - & - & - & 17.29 & 16.32 & 16.12 & - & - \\
\hline Cycloartenol & 1.63 & - & - & 2.26 & 0 & 0 & - & - \\
\hline Citrostadienol & 1.3 & - & - & 3.3 & 0 & 0 & - & - \\
\hline $\begin{array}{l}\text { Total sterol } \\
(\mathrm{mg} / 100 \mathrm{~g})\end{array}$ & 2460 & 2730 & 2590 & 2490 & 1931 & 2140 & 2488.7 & 2762 \\
\hline Reference & [7] & [33] & {$[33]$} & [27] & [27] & [27] & [21] & {$[21]$} \\
\hline \multicolumn{9}{|c|}{$\begin{array}{l}\text { I, hexane extracted oil; } \mathrm{II} \text {, crude oil extracted by hexane at } 50-55^{\circ} \mathrm{C} \text { under atmospheric pressure; } \mathrm{III} \text {, refined } \\
\text { amaranth oil; } \mathrm{IV} \text {, oil extracted by supercritical } \mathrm{CO}_{2} \text { under } 306 \text { atm and } 50^{\circ} \mathrm{C} ; \mathrm{V} \text {, cold press oil; } \mathrm{VI} \text {, solvent extracted } \\
\text { oil by chloroform: methanol }(2: 1 \mathrm{v} / \mathrm{v}) . \\
{ }^{a} \alpha \text {-Spinasterol }+ \text { sitosterol }+ \text { chondrillasterol. } \\
{ }^{b} \alpha \text {-Spinasterol + sitosterol. }\end{array}$} \\
\hline
\end{tabular}

Table 4.

Phytosterol composition of different Amaranthus species. 
rapeseed oil (450-1130 mg/100 g), safflower oil (210-460 mg/100 g), sesame oil (450-1900 mg/100 g), soybean oil (180-450 mg/100 g), and sunflower oil $(240-500 \mathrm{mg} / 100 \mathrm{~g})[34,35]$. However, wheat germ oil $(4240 \mathrm{mg} / 100 \mathrm{~g})$ and rice bran oil (1050-3100 mg/100 g) have total phytosterol content higher than amaranth oil $[34,36]$.

The phytosterol composition of the different Amaranthus species is presented in Table 4. The predominant phytosterol in the Amaranthus cruentus seed oil is the mixture of $\alpha$-spinasterol and sitosterol $[19,21,27] . \Delta^{7}$-Sterols, that is, $\Delta^{7}$ stigmastenol and $\Delta^{7}$-avenasterol and in some cases $\Delta^{7}$-ergosterol and $\Delta^{7}$-ergostenol, are also present in considerable amounts in Amaranthus cruentus seed oil [7, 27, 33]. However, $\Delta^{7}$-campesterol and $\Delta^{5}$-avenasterol are the major phytosterols of Amaranthus dubius and Amaranthus tricolor species. They also contain stigmasterol and $\Delta^{5,24}$-stigmastadienol in considerable concentrations [21].

\section{Tocopherols and tocotrienols}

Tocopherols and tocotrienols (i.e., tocols) are a part of unsaponifiable fraction, which are forms of vitamin $\mathrm{E}$ and act as natural antioxidants in the vegetable oils. Tocotrienols are structurally similar to the tocopherols, except that tocotrienols have three double bonds within their phytol chains [37]. They have a chromanol ring attached to a phytol chain. Each of tocopherols and tocotrienols is divided into four subclasses, $\alpha-, \beta-, \gamma-$, and $\delta$ - forms, which differ from each other as to the number of methyl groups on the chromanol ring [38]. The structure of eight homologs of tocopherols and tocotrienols is presented in Figure 2.

Tocopherols comprise the majority of the tocols in most of the common oils. However, tocotrienols are predominant in palm, rice bran, grape seed, and barely oils $[39,40]$. It has been reported that amaranth seed has small or negligible amounts of tocotrienols $[7,18]$. However, there are also reports that amaranth seed oil has tocotrienol content higher than some vegetable oils, such as soybean oil, peanut oil, and olive oil $[21,41]$.

$\gamma$-Tocopherol is the dominant tocol in most edible oils such as corn, soybean, rapeseed, sesame seed, and flaxseed oils. While $\alpha$-tocopherol is the most abundant tocol in some vegetable oils such as safflower, sunflower, and olive oils [40]. Total and individual content of tocol homologs depends on the amaranth species, varieties, variation in analytical and extraction methods, and also growing location and cultivation conditions $[18,42]$. The total tocol content of 21 amaranth accessions has been reported to be $31.5-78.3 \mathrm{mg} / \mathrm{kg}$ seed (wet basis), with an average of $49.4 \mathrm{mg} / \mathrm{kg}$ seed (wet basis) [18].

The study on the effect of dosages of fertilization with macronutrients on the tocopherol profile of two varieties of Amaranthus cruentus seeds revealed that the total tocopherol content was $48.6-79.9 \mathrm{mg} / \mathrm{kg}$ (dry matter) [42]. Applying various extraction methods, the determined contents of tocopherol homologs of the commercial and wild Amaranthus caudatus seed were $12.5-47.84$ (mg/kg seed) $\alpha$-tocopherol, $19.55-61.56$ ( $\mathrm{mg} / \mathrm{kg}$ seed) $\beta$-tocopherol, 0.6-4.99 (mg/kg seed) $\gamma$-tocopherol, and 2.1-48.79 (mg/kg seed) $\delta$-tocopherol [20]. Depending on the supercritical $\mathrm{CO}_{2}$ extraction parameters, the tocopherol homologs of amaranth seed have s been reported as follows: $2.37-9.79$ ( $\mathrm{mg} / \mathrm{kg}$ seed) $\alpha$-tocopherol, $82.42-211.8$ (mg/kg seed) $\beta$-tocopherol, 12.36-57.07 ( $\mathrm{mg} / \mathrm{kg}$ seed) $\gamma$-tocopherol, and 14.8938.59 ( $\mathrm{mg} / \mathrm{kg}$ seed) $\delta$-tocopherol [43]. The tocopherol composition of $\mathrm{n}$-hexane extracted amaranth grain oil is presented in Table 5. It has been reported that the total tocopherol content of n-hexane extracted amaranth oil is between 656.8 and $2588 \mathrm{mg} / \mathrm{kg}$ oil [7, 21, 33]. 
<smiles>Cc1c(C)c2c(c(C)c1O)CC[C@@](C)(CCCC(C)CCCC(C)CCCC(C)C)O2</smiles>

$\alpha$-Tocopherol<smiles>Cc1cc(O)c(C)c2c1O[C@](C)(CCCC(C)CCCC(C)CCCC(C)C)CC2</smiles>

$\beta$-Tocopherol<smiles>Cc1c(O)cc2c(c1C)O[C@](C)(CCCC(C)CCCC(C)CCCC(C)C)CC2</smiles>

$\gamma$-Tocopherol<smiles>Cc1cc(O)cc2c1O[C@](C)(CCCC(C)CCCC(C)CCCC(C)C)CC2</smiles>

$\delta$-Tocopherol<smiles>CC(C)=CCC/C(C)=C/CC/C(C)=C/CC[C@]1(C)CCc2c(C)c(O)c(C)c(C)c2O1</smiles>

$\alpha$-Tocotrienol<smiles>CC(C)=CCC/C(C)=C/CC/C(C)=C/CC[C@]1(C)CCc2c(C)c(O)cc(C)c2O1</smiles>

$\beta$-Tocotrienol<smiles>CC(C)=CCC/C(C)=C/CC/C(C)=C/CC[C@@]1(C)CCc2cc(O)c(C)c(C)c2O1</smiles>

$\gamma$-Tocotrienol<smiles>CC(C)=CCC/C(C)=C/CC/C(C)=C/CC1(C)CCc2cc(O)cc(C)c2O1</smiles>

$\delta$-Tocotrienol

Figure 2.

Structure of different forms of tocopherols and tocotrienols.

\begin{tabular}{lcccccc}
\hline & $\boldsymbol{\alpha}-\mathbf{T}$ & $\boldsymbol{\beta}-\mathbf{T}$ & $\boldsymbol{\gamma}$ - & $\boldsymbol{\delta}$-T & Total tocopherols & Source \\
\hline A. tricolor & 74.2 & 157.9 & 17.4 & 407.2 & 656.8 & {$[21]$} \\
\hline A. dubius & 135 & 245.7 & 22.3 & 376.4 & 779.5 & {$[21]$} \\
\hline A. cruentus & 248 & 546 & - & 8 & 802 & {$[7]$} \\
\hline A. cruentus (crude oil) & 392 & 299 & 1187 & 710 & 2588 & {$[33]$} \\
\hline A. cruentus (refined oil) & 232 & 225 & 728 & 603 & 1788 & {$[33]$} \\
\hline$\alpha$-T, $\alpha$-tocopherol; $\beta$-T, $\beta$-tocopherol; $\gamma$-T, $\gamma$-tocopherol; $\delta$-T, $\delta$-tocopherol. & & \\
\hline
\end{tabular}

Table 5.

Tocopherol concentration $(\mathrm{mg} / \mathrm{kg}$ oil) of $n$-hexane extracted oils from different species of amaranth grain.

\section{Carotenoids}

Carotenoids are essential photosensitizers, which have an important role in plant photosynthesis. They are also considered as provitamin A and possess antioxidative properties [44]. The two carotenoids lutein (3.55-4.44 mg/kg seeds) and zeaxanthin (trace to $0.32 \mathrm{mg} / \mathrm{kg}$ seeds) have been detected in amaranth seeds, lutein being the predominant one. $\beta$-Carotene, the most known carotenoid, has not been detected in amaranth seeds [45]. 


\section{Phospholipids}

Phospholipids are essential polar lipid materials that have an important role in biological membranes. TAGs are the major components of the nonpolar fraction of the lipid. However, phospholipids are the main compounds of the polar fraction of the lipids, which are considered as bound lipids. The phospholipid content of the amaranth grain oil has been reported to be in the range of $9.1-10.2 \%$ of total lipids [11].

\section{Oxidative stability}

Concerning the high concentration of squalene and tocopherols, the amaranth oil is expected to have good oxidative stability. Oxidative stability of amaranth oil was determined by monitoring the peroxide value at $60^{\circ} \mathrm{C}$ for 30 days. It has been reported that amaranth oil had good oxidative stability, even better than the oxidative stability of sunflower oil [11]. However, direct investigation of the stability of crude amaranth oil obtained opposite results. It has been reported that although amaranth oil contains high concentrations of squalene and tocopherols, which are strong antioxidants, it did not have good oxidative stability [46].

\section{Conclusion}

Amaranth grain contains 5-8\% oil, which is mainly comprised of triacylglycerols (78-82\%). The oil also contains important minor phytochemicals, such as squalene (up to $10 \%$ ), phytosterols (2-3\%), tocopherols, carotenoids, and phospholipids (up to 10\%). The high content of tocopherols and squalene, which act as antioxidants, provides high oxidative stability for amaranth oil. The unique composition of amaranth seed oil makes it a useful ingredient in the food, pharmaceutical, and cosmetic industries.

\section{Conflict of interest}

The authors declare no conflict of interest. 


\section{Author details}

Parisa Nasirpour-Tabrizi ${ }^{1}$, Sodeif Azadmard-Damirchi ${ }^{1,2 *}$, Javad Hesari ${ }^{1}$ and Zahra Piravi-Vanak ${ }^{3}$

1 Department of Food Science and Technology, Faculty of Agriculture, University of Tabriz, Tabriz, Iran

2 Food and Drug Safety Research Center, Health Management and Safety Promotion Research Institute, Tabriz University of Medical Sciences, Tabriz, Iran

3 Food Technology and Agricultural Products Research Center, Standard Research Institute (SRI), Karaj, Iran

*Address all correspondence to: sodeifazadmard@yahoo.com;

s-azadmard@tabrizu.ac.ir

\section{IntechOpen}

(C) 2020 The Author(s). Licensee IntechOpen. This chapter is distributed under the terms of the Creative Commons Attribution License (http://creativecommons.org/licenses/ by/3.0), which permits unrestricted use, distribution, and reproduction in any medium, provided the original work is properly cited. (cc) BY 


\section{References}

[1] Mota C, Santos M, Mauro R, Samman N, Matos AS, Torres D, et al. Protein content and amino acids profile of pseudocereals. Food Chemistry. 2016;193:55-61. DOI: 10.1016/j. foodchem.2014.11.043

[2] Caselato-Sousa VM, Amaya-Farfán J. State of knowledge on amaranth grain: A comprehensive review. Journal of Food Science. 2012;77(4):R93-R104. DOI: $10.1111 /$ j.1750-3841.2012.02645.x

[3] Mlakar SG, Turinek M, Jakop M, Bavec M, Bavec F. Nutrition value and use of grain amaranth: potential future application in bread making. Agricultura. 2009;6(4):43-53

[4] Písaříková B, Kráčmar S, Herzig I. Amino acid contents and biological value of protein in various amaranth species. Czech Journal of Animal Science. 2005;50(4):169-174. DOI: 10.17221/4011-CJAS

[5] Gimplinger D, Dobos G, Schonlechner R, Kaul H. Yield and quality of grain amaranth (Amaranthus sp.) in Eastern Austria. Plant Soil and Environment. 2007;53(3):105-112

[6] Kraujalis P, Venskutonis PR, Pukalskas A, Kazernavičiūtė R. Accelerated solvent extraction of lipids from Amaranthus spp. seeds and characterization of their composition. LWT- Food Science and Technology. 2013;54(2):528-534. DOI: 10.1016/j. lwt.2013.06.014

[7] León-Camacho M, GarcíaGonzález DL, Aparicio R. A detailed and comprehensive study of amaranth (Amaranthus cruentus L.) oil fatty profile. European Food Research and Technology. 2001;213(4-5):349-355. DOI: $10.1007 / \mathrm{s} 002170100340$

[8] Krulj J, Brlek T, Pezo L, Brkljača J, Popović S, Zeković Z, et al. Extraction methods of Amaranthus sp. grain oil isolation. Journal of the Science of Food and Agriculture. 2016;96(10):3552-3558. DOI: $10.1002 /$ jsfa.7540

[9] Westerman D, Santos R, Bosley J, Rogers J, Al-Duri B. Extraction of Amaranth seed oil by supercritical carbon dioxide. The Journal of Supercritical Fluids. 2006;37(1):38-52. DOI: 10.1016/j.supflu.2005.06.012

[10] Shaddel R, Maskooki A, Haddad-Khodaparast MH, AzadmardDamirchi S, Mohamadi M, FathiAchachlouei B. Optimization of extraction process of bioactive compounds from Bene hull using subcritical water. Food Science and Biotechnology. 2014;23(5):1459-1468. DOI: $10.1007 /$ s10068-014-0200-7

[11] Gamel TH, Mesallam AS, Damir AA, Shekib LA, Linssen JP. Characterization of amaranth seed oils. Journal of Food Lipids. 2007;14(3):323-334. DOI: 10.1111/j.1745-4522.2007.00089.x

[12] Martirosyan DM, Miroshnichenko LA, Kulakova SN, Pogojeva AV, Zoloedov VI. Amaranth oil application for coronary heart disease and hypertension. Lipids in Health and Disease. 2007;6(1):1. DOI: 10.1186/1476-511X-6-1

[13] Jahaniaval F, Kakuda Y, Marcone M. Fatty acid and triacylglycerol compositions of seed oils of five Amaranthus accessions and their comparison to other oils. Journal of the American Oil Chemists' Society. 2000;77(8):847-852. DOI: $10.1007 /$ s11746-000-0135-0

[14] Lyon C, Becker R. Extraction and refining of oil from amaranth seed. Journal of the American Oil Chemists' Society. 1987;64(2):233-236. DOI: 10.1007/BF02542008 
[15] He H-P, Corke H. Oil and squalene in amaranthus grain and leaf. Journal of Agricultural and Food Chemistry. 2003;51(27):7913-7920. DOI: 10.1021/ jf030489q

[16] He H-P, Cai Y, Sun M, Corke H. Extraction and purification of squalene from Amaranthus grain. Journal of Agricultural and Food Chemistry. 2002;50(2):368-372. DOI: 10.1021/ jf010918p

[17] Berganza BE, Moran AW, Rodríguez GM, Coto NM, Santamaría M, Bressani R. Effect of variety and location on the total fat, fatty acids and squalene content of amaranth. Plant Foods for Human Nutrition. 2003;58(3):1-6. DOI: 10.1023/B:QUAL.0 000041143.24454.0a

[18] Budin JT, Breene WM, Putnam DH. Some compositional properties of seeds and oils of eight Amaranthus species. Journal of the American Oil Chemists' Society. 1996;73(4):475-481. DOI: 10.1007/BF02523922

[19] Ogrodowska D, Zadernowski R, Czaplicki S, Derewiaka D,

Wronowska B. Amaranth seeds and products-the source of bioactive compounds. Polish Journal of Food and Nutrition Sciences. 2014;64(3):165-170. DOI: $10.2478 / \mathrm{v} 10222-012-0095-\mathrm{z}$

[20] Bruni R, Medici A, Guerrini A, Scalia S, Poli F, Muzzoli M, et al. Wild Amaranthus caudatus seed oil, a nutraceutical resource from Ecuadorian flora. Journal of Agricultural and Food Chemistry. 2001;49(11):5455-5460. DOI: $10.1021 /$ jf010385k

[21] Z-s Z, Y-j K, Che L. Composition and thermal characteristics of seed oil obtained from Chinese amaranth. LWT. 2019;111:39-45. DOI: 10.1016/j. lwt.2019.05.007

[22] Huang Z-R, Lin Y-K, Fang J-Y. Biological and pharmacological activities of squalene and related compounds: Potential uses in cosmetic dermatology. Molecules. 2009;14(1):540-554. DOI: 10.3390/ molecules14010540

[23] Popa O, Băbeanu NE, Popa I, Niță S, Dinu-Pârvu CE. Methods for obtaining and determination of squalene from natural sources. BioMed Research International. 2015;2015. Article ID: 367202. DOI: $10.1155 / 2015 / 367202$

[24] Frega N, Bocci F, Lercker G. Direct gas chromatographic analysis of the unsaponifiable fraction of different oils with a polar capillary column. Journal of the American Oil Chemists' Society. 1992;69(5):447-450. DOI: 10.1007/ BF02540946

[25] Naziri E, Mantzouridou F, Tsimidou MZ. Squalene resources and uses point to the potential of biotechnology. Lipid Technology. 2011;23(12):270-273. DOI: 10.1002/ lite. 201100157

[26] Sun H, Wiesenborn D, Tostenson K, Gillespie J, Rayas-Duarte P. Fractionation of squalene from amaranth seed oil. Journal of the American Oil Chemists' Society. 1997;74(4):413-418. DOI: 10.1007/s11746-997-0099-8

[27] Czaplicki S, Ogrodowska D, Zadernowski R, Derewiaka D. Characteristics of biologically-active substances of amaranth oil obtained by various techniques. Polish Journal of Food and Nutrition Sciences. 2012;62(4):235-239. DOI: $10.2478 /$ v10222-012-0054-8

[28] Bozorov SS, Berdiev NS, Ishimov UJ, Olimjonov SS, Ziyavitdinov JF, Asrorov AM, et al. Chemical composition and biological activity of seed oil of amaranth varieties. Nova Biotechnologica et Chimica. 2018;17(1):66-73. DOI: 10.2478/nbec-2018-0007 
[29] Azadmard-Damirchi S, Dutta PC. Stability of minor lipid components with emphasis on phytosterols during chemical interesterification of a blend of refined olive oil and palm stearin. Journal of the American Oil Chemists' Society. 2008;85(1):13-21. DOI: 10.1007/ s11746-007-1170-1

[30] Azadmard-Damirchi S, Emami S, Hesari J, Peighambardoust S, Nemati M. Nuts composition and their health benefits. World Academy of Science, Engineering and Technology. 2011;5:544-548. DOI: 10.5281/ zenodo.1329785

[31] Azadmard-Damirchi S, Dutta PC. Free and esterified 4, 4 '-dimethylsterols in hazelnut oil and their retention during refining processes. Journal of the American Oil Chemists' Society. 2007;84(3):297-304. DOI: $10.1007 / \mathrm{s} 11746-006-1025-1$

[32] Phillips KM, Ruggio DM, Toivo JI, Swank MA, Simpkins AH. Free and esterified sterol composition of edible oils and fats. Journal of Food Composition and Analysis. 2002;15(2):123-142. DOI: 10.1006/ jfca.2001.1044

[33] Berger A, Monnard I, Dionisi F, Gumy D, Hayes K, Lambelet P. Cholesterol-lowering properties of amaranth flakes, crude and refined oils in hamsters. Food Chemistry. 2003;81(1):119-124. DOI: 10.1016/S0308-8146(02)00387-4

[34] Alimentarius C. Codex standard for named vegetable oils. Codex stan 2101999. Rome, Italy: FAO/WHO; 2019. pp. 1-13

[35] Yang R, Xue L, Zhang L, Wang X, Qi X, Jiang J, et al. Phytosterol contents of edible oils and their contributions to estimated Phytosterol intake in the Chinese diet. Food. 2019;8(8):334. DOI: 10.3390/foods 8080334
[36] Schwartz H, Ollilainen V, Piironen V, Lampi A-M. Tocopherol, tocotrienol and plant sterol contents of vegetable oils and industrial fats. Journal of Food Composition and Analysis. 2008;21(2):152-161. DOI: 10.1016/j.jfca.2007.07.012

[37] Ahsan H, Ahad A, Siddiqui WA. A review of characterization of tocotrienols from plant oils and foods. Journal of Chemical Biology. 2015;8(2):45-59. DOI: $10.1007 /$ s12154-014-0127-8

[38] Grilo EC, Costa PN, Gurgel CSS, AFdL B, FNdS A. Dimenstein R. Alphatocopherol and gamma-tocopherol concentration in vegetable oils. Food Science and Technology. 2014;34(2):379-385. DOI: 10.1590/ S0101-20612014005000031

[39] Wie M, Sung J, Choi Y, Kim Y, Jeong HS, Lee J. Tocopherols and tocotrienols in grape seeds from 14 cultivars grown in Korea. European Journal of Lipid Science and Technology. 2009;111(12):1255-1258. DOI: $10.1002 /$ ejlt.200900058

[40] Shahidi F, De Camargo AC. Tocopherols and tocotrienols in common and emerging dietary sources: Occurrence, applications, and health benefits. International Journal of Molecular Sciences. 2016;17(10):1745. DOI: $10.3390 /$ ijms17101745

[41] Lehmann JW, Putnam DH, Qureshi AA. Vitamin E Isomers in grain amaranths (Amaranthus spp.). Lipids. 1994;29(3):177-181. DOI: 10.1007/ BF02536726

[42] Skwaryło-Bednarz B. Assessment of content of fat and tocopherols in seeds of Amaranthus in relation to diversified fertilization with macroelements. Ecological Chemistry and Engineering S. 2012;19(2):273-279. DOI: 10.2478/v10216-011-0021-z 
[43] Kraujalis P, Venskutonis PR.

Supercritical carbon dioxide extraction of squalene and tocopherols from amaranth and assessment of extracts antioxidant activity. The Journal of Supercritical Fluids. 2013;80:78-85. DOI: 10.1016/j.supflu.2013.04.005

[44] Tang Y, Tsao R. Phytochemicals in quinoa and amaranth grains and their antioxidant, anti-inflammatory, and potential health beneficial effects: A review. Molecular Nutrition \& Food Research. 2017;61(7):1600767. DOI: 10.1021/acs.jafc.5b05414

[45] Tang Y, Li X, Chen PX, Zhang B, Liu R, Hernandez M, et al. Assessing the fatty acid, carotenoid, and tocopherol compositions of amaranth and quinoa seeds grown in Ontario and their overall contribution to nutritional quality. Journal of Agricultural and Food Chemistry. 2016;64(5):1103-1110. DOI: 10.1021/acs.jafc.5b05414

[46] Szterk A, Roszko M, Sosińska E, Derewiaka D, Lewicki P. Chemical composition and oxidative stability of selected plant oils. Journal of the American Oil Chemists' Society. 2010;87(6):637-645. DOI: 10.1007/ s11746-009-1539-4 



\title{
Kinetics and Thermodynamics of Oil Extracted from Amaranth
}

\author{
Chinedu M. Agu and Albert C. Agulanna
}

\begin{abstract}
This chapter deals with the kinetics of solvent extraction of oil from Amaranth, as well as the thermodynamics of the extraction process. Brief introduction of Amaranth and Amaranth oil yields and compositions were given. The justifications of the choice of extraction method, as well as the solvent used in the kinetics and thermodynamic studies, were discussed. Known kinetic models used to model vegetable oils extraction process, were discussed, with the view of evaluating the feasibility of fitting the obtained experimental data into the models. The extraction kinetic models considered are the parabolic diffusion, power law, hyperbolic, Elovich's and pseudo second order models. The thermodynamics of oil extraction process were also considered. Hence, the thermodynamic parameters, enthalpy, entropy and Gibb's free energy change of the process were also discussed.
\end{abstract}

Keywords: kinetics, thermodynamics, Amaranth, oil extraction, solvent extraction method

\section{Introduction}

Amaranth plant is a strong and fast-growing pseudocereal that is nutritious and is presently used as food crop. The common species of Amaranth grains are Amaranthus cruentus, Amaranthus caudatus, and Amaranthus hypochondriacus [1]. It has lot of nutritional and health benefits due to its fiber content, tocols, high protein content, squalene, as well as diverse bioactive compounds. Amaranthus sp. grain also contains high concentration of minerals, vitamins, specially tocotrienols lysine amino acids and fatty acids [2]. Various species of Amaranth are planted in several parts of the world, such as South America, Africa, India, China and United States [3]. Composition of seeds from the several species of Amaranthus have been reported to contain protein, starch and oil, that are of high quality for food and animal feed purposes [4].

Amaranth grains have been reported by number researchers to contain about $6-9 \%$ oil $[1,4-6]$. Although the oil yield of Amaranth is low, it is often not extracted from the seeds, though there are situations where it would be advantageous to extracted and use the oil [4]. This is because the oil is very rich in squalene, compared to other vegetable oils, like olive, rice bran, corn, peanut, rapeseed, cottonseed and sunflower [5-9]. The oil of Amaranth is reported to contain high quantity of squalene, of up to $7.3-11.2 \%[1,3,10]$. Oil from Amaranthus sp., also contains other important substances like crude fat and some essential fatty acids [11]. 
It is important to know that the fatty acids present in Amaranth seeds oil, are similar to those present in other cereals, like cottonseed and sesame oils [1]. For instance, the oil of Amaranthus cruentus, have been reported to contain $6.3 \%$ crude fat, 38.2\% linoleic acid, 33.3\% oleic acid, $4 \%$ stearic acid, $1 \%$ linolenic acid, and $20 \%$ palmitic acid [11]. In Amaranth oil, the major carbon number present ranges from C50 to C54. This value is in the range reported for corn and cottonseed oils [12]. In addition, Amaranth oil has high amount of unsaponifiable matter of about $8 \%$. This value is higher than the values of other oils, like sunflower (0.3-1.2), soybean (0.6-1.2) and olive (0.4-1.1) [1,13]. Furthermore, Amaranth seeds oil contains other lipid components other than squalene. These components are phospholipids, glycolipids and sterols [14].

Of the lipid and oil components of Amaranth, squalene is of very high importance. This is because of its applications in various industrial products, hence, the need to briefly highlight it. Squalene is a type of unsaponifiable lipid which functions as a biosynthetic precursor, to all steroids (phytosterols and cholesterol) in both plants and animals $[6,15]$. It is a triterpene $\left(\mathrm{C}_{30} \mathrm{H}_{50}\right)$, often found in tissues of plants and animals [15]. Many research works have shown the biochemical importance squalene as antioxidant [15-18], as well as chemopreventive agent [19]. The economic and industrial importance of squalene cannot be overemphasized, due to its numerous applications. For instance, commercially, about 93 million dollars is the value of just 2500 tons of squalene that was produced in 2013 [15]. Industrially, it is used as an essential ingredient in skin cosmetics $[1,3,10,14,15]$, due to it photoprotective ability, as well as a lubricant for computer disk $[3,10,14]$, due to its thermostability [14]. Furthermore, in the area of health, squalene decreases different cancer(s) risk [10,14], as well as reduces serum cholesterol levels [10].

From the forgoing, it could be seen that it is very important to extract oil from Amaranth seeds, especially due to the already highlighted vital industrial applications of its component, squalene. In other words, it is important to understand the extraction methods that could be used to extract oil from Amaranth, as well as justify the method to be used in the kinetics and thermodynamics studies of the extraction process. This chapter therefore, seeks to also look at the kinetics and thermodynamics of Amaranth seeds/grains oil extraction, using known extraction kinetics models. The models considered here are, parabolic diffusion, power law, hyperbolic, Elovich's and pseudo second order models. Also, the thermodynamic parameters evaluated are, enthalpy, entropy and Gibb's free energy change of the extraction process.

\section{Methods of oil extraction from Amaranth seeds/grains}

A number of very important factors affect extraction processes, irrespective of the substance being extracted (in this case Amaranth seeds), or the extraction method used. These factors include, but not limited to matrix properties of the material (plants, seeds, nuts, and leaves), solvent, extraction time, temperature, pressure [20, 21]. Oil extraction from seeds/nuts such as, Amaranth can be done using different methods. These extraction methods can be categorized into conventional (common) and non-conventional (new/novel techniques) methods [22-24].

Conventional (common) methods comprise of hydro-distillation (HD), steam distillation, cold pressing (CP), mechanical pressing, solvent extraction and simultaneous distillation-extraction methods, among others $[23,25]$. On the other hand, non-conventional (novel) extraction methods include supercritical fluid extraction [26-29], pressurized liquid extraction (PLE) or pressurized fluid extraction (PFE) or accelerated fluid extraction (ASE) or enhanced/accelerated solvent extraction (ESE) or high pressure solvent extraction (HPSE) [30, 31], microwave-assisted 
extraction (MAE) [32-34], ultrasound-assisted extraction (UAE) [35-37], pulsedelectric field extraction (PEF) [38, 39], enzyme-assisted extraction (EAE) [40, 41], among others $[23,24]$.

Though the conventional techniques have been used over the years for various extraction purposes, with Amaranth oil extraction inclusive, they have their peculiar shortcomings, such as, low extraction efficiency in case of cold pressing and hydro distillation. Also, in the mechanical pressing and steam distillation conventional methods, degradation of unsaturated, or ester compounds through thermal or hydrolytic effects, are the main disadvantages associated them. In the case of solvent extraction method, the likely residual toxic solvent in the extracts or oil is its major shortcoming [23].

As a result of these short comings associated with traditional conventional (hydro-distillation, steam distillation, cold pressing, mechanical pressing, solvent extraction and distillation) methods, several non-conventional techniques earlier stated, are currently in use for oil extraction and other extracts from seeds/nuts, plants, flowers, leaves etc. [23, 24]. These novel methods have the advantage of functioning efficiently at elevated operating conditions (temperatures and/or pressures), thus decreasing the extraction time, significantly [24].

Nonetheless, conventional extraction methods, such as solvent extraction using Soxhlet extractor, is still considered as one of the reference methods, to compare success with the newly developed non-conventional (novel) methods [22, 24]. Soxhlet extraction as a well-established technique is more efficient than other conventional extraction methods, except in limited applications like, the extraction of thermo labile compounds [24]. It is important to state that Soxhlet extractor was first proposed by German chemist, Franz Ritter Von Soxhlet in 1879. Initially, it was designed primarily for lipid extraction, but presently it is no longer limited to this purpose alone. Soxhlet extractor is now widely used for the extraction of valuable substances such as bioactive compounds, oils, etc. [22], with Amaranth oil not being left out.

\section{Justifications for the choice of Soxhlet extractor and solvent(s)}

In the operation of Soxhlet extractor, it uses solvent in its operation for the extraction of valuable substances from the solute. In this case, for extraction of oil from Amaranth seeds/grains. For the operation of the extractor, different types of solvents, which can be used for extraction purposes, exist. These solvents will yield different quantities of the Amaranth oil. However, the most widely-used solvent for the extraction of oils from plants, seeds and nuts, irrespective of whether is Amaranth or any other seed/nut, is hexane. Hexane has a fairly narrow boiling point range of approximately $63-69^{\circ} \mathrm{C}$, and it is an excellent solvent for oil extraction, especially in terms of solubility and ease of recovery [24].

Over the years, solvent extraction (by Soxhlet apparatus) using different solvents, have been used to extract oil from Amaranth seeds. For instance, He and Corke [6] successfully used Soxhlet apparatus to extract oil from Amaranthus grain, using petroleum ether (boiling point range $40-60^{\circ} \mathrm{C}$ ) as the extracting solvent. They obtained an average Amaranth oil yield of 5.0\%. Similarly, Ortega et al. [14] used Soxhlet apparatus in the extraction of Amaranth oil, using hexane as the solvent. In the work of Krulj et al. [2], Soxhlet apparatus was also used for Amaranthus sp. grain oil extraction, using petroleum ether (boiling point range $40-60^{\circ} \mathrm{C}$ ), with obtained oil yield of $70-75.7 \mathrm{~g} / \mathrm{kg}$ weight. Even as early as 1987 , Lyon and Becker [4] had used Soxhlet apparatus for oil extraction from Amaranth seed, using hexane as solvent, and obtained oil yield of 7.01\%. Several authors have also used this Soxhlet apparatus for oil extraction from Amaranth seeds. 
The benefits of Soxhlet apparatus have also attracted its use for other vegetable oils extraction, from a wild number of other seeds/nuts, using different solvents. For instance, in the extraction of oil from African star apple (Chrysophyllum albidum) using Soxhlet extractor, Adebayo et al. [42] used hexane solvent and $10.71 \%$ yield was recorded. In case of oil extraction from Hibiscus cannabinus $\mathrm{L}$. seed, Chan and Ismail [43] obtained a yield of 24.81\%, using hexane; while Mariod et al. [44] got a yield of $62.38 \%$ using the same solvent. Furthermore, in the extraction of oil from Plukenetia volubilis seed using petroleum ether, Niu et al. [45] reported an oil yield of 39\% using Soxhlet apparatus. Omeh et al. [46] reported a yield of $65 \%$ for the extraction of oil from Irvingia Gabonensis seeds, using hexane. Lasekan and Abdulkarim [47] successfully extracted oil from tiger nut (Cyperus esculentus L.), using n-hexane and yield of $26.28 \%$ was obtained. In case of Terminalia catappa oil extraction using Soxhlet extractor, yields of 49,60.45 and 61.98\% were reported by Dos Santos et al. [48], Menkiti et al. [49] and Adepoju et al. [50], respectively, using hexane. Many other authors too numerous to mention, have also successfully used Soxhlet extractor for oil extraction from seeds/ nuts, because of its benefits/advantages.

This extensive use of Soxhlet apparatus (in solvent extraction) method was possible due to a number of its advantages. The advantages of using conventional Soxhlet extraction method include: (1) the displacement of transfer equilibrium by repeatedly bringing fresh solvent in contact with the solid matrix, (2) maintaining a relatively high extraction temperature with heat from the distillation flask, (3) cheapness and simplicity in operating the Soxhlet apparatus, and (4) filtration is not required after leaching $[24,51]$. That notwithstanding, solvent extraction method using Soxhlet apparatus, is not without a number of shortcomings. Some of the disadvantages of conventional Soxhlet extraction include: (1) large quantity of solvent is required, (2) lengthy extraction time, (3) inability to provide agitation in the device in other to speed up the process [24].

On the other hand, N-hexane has been extensively used over the years as the preferred solvent for oil extraction from Amaranth seeds $[4,5,14]$, as well as other seeds/nuts $[49,65]$, compared to other solvents $[2,6]$. This was attributed to its nonpolar nature (low polarity index of 0.0 ), compared to the polarity indexes of other nonpolar solvents, like petroleum ether [49]. Table 1 shows the oil yield,

\begin{tabular}{lclll}
\hline Solvent & Yield ${ }^{\mathrm{a}}(\%)$ & $\begin{array}{l}\text { Boiling } \\
\text { Point }{ }^{\circ} \mathrm{C}\end{array}$ & Polarity & $\begin{array}{l}\text { Polarity } \\
\text { Index }\end{array}$ \\
\hline Hexane & 60.45 & 68.7 & Nonpolar & 0.0 \\
Petroleum ether & 56.00 & $60-80$ & Nonpolar & 0.1 \\
Benzene & 48.50 & 80.1 & Nonpolar & 2.7 \\
Chloroform & 40.00 & 61.2 & Polar & 4.1 \\
$\begin{array}{l}\text { Ethanol } \\
\text { a Experimental oil yield values at } 55^{\circ} \mathrm{C} \text { and } 150 \mathrm{mins}\end{array}$ \\
\hline
\end{tabular}

Table 1.

Oil yield, boiling point and polarity/polarity index of solvents used in Terminalia catappa kernel oil extraction (source, Menkiti et al. [49]). 
boiling point, polarity/polarity index of solvents, used in the preliminary evaluation of solvents effects on the oil yield of Terminalia catappa kernel (source, Menkiti et al. [49]). Also, its high boiling point $63-69^{\circ} \mathrm{C}$, when compared to other solvents like petroleum ether, benzene, chloroform, methanol etc., is another added advantage $[24,49]$. Lately, new solvents have been tested in extraction processes. Some of the tested solvents include but not limited to acetone, ethanol and isopropanol [52-56]. Nevertheless, only ethanol, isopropanol and occasionally acetone are permitted for use as solvents in the food industry, due to their minimal waste generation [57]. Thus, the advantages of hexane still supersede those of these solvent. Therefore, Soxhlet apparatus and hexane were used for ease of discussion of the kinetics and thermodynamics of Amaranth seed oil extraction.

\section{Kinetics and kinetic models that could be used to model oil extraction from Amaranth seeds/grains}

During solvent extraction using Soxhlet extractor, it is important to determine the rate at which equilibrium is attained between a miscella and oil and solvent, within the particles, irrespective of the seeds/nuts $[58,59]$. There is therefore need to study the kinetics of Amaranth seed oil extraction, prior to evaluation of the existing kinetic models, that could be used to fit the obtained extraction kinetics data. Within the knowledge disposal of the author, there is no published article on the results of the kinetics of oil extraction from Amaranth seeds, hence, the need to evaluate the possible kinetic models that could be used to fit its oil extraction data, when obtained.

Therefore, due to the importance of kinetics with respect to oil extraction, a number of kinetic models have been proposed to analyze the kinetics of oil extraction processes for different seeds/nuts. Some of these seeds, nuts and kernels include but not limited to, partially dehulled sunflower [60], rapeseed [61, 62], confectionery, oilseed and wild sunflower [63], sunflower collets [64], Terminalia catappa [49], Colocynthis vulgaris Schrad [65] and olive cake [66].

These kinetic models can be classified into physical and empirical ones. Physical models are the models that are based on the physical phenomena of mass transfer, through the seeds/nuts particles and from external solid surfaces, into the bulk of the liquid phases $[49,67,68]$. On the other hand, empirical models are the models that describe mathematically variations of extractive substance amount in either seeds/nuts material or liquid extract with time $[49,68]$.

However, the empirical models would be treated in this section. These empirical models are ordinarily simpler than physical ones, and are also suitable for engineering purposes $[49,67]$. Some examples of these models includes: power law model, hyperbolic model, parabolic diffusion model, Elovich's model, Weibull's model, pseudo second order model, and pseudo first order model [49, 67, 68]. These empirical kinetic models have been successfully used to model oil extraction from a number of seed/nuts. For instance, Menkiti et al. [49, 68], used power law, parabolic diffusion, hyperbolic, Elovich's and pseudo second order models, for Terminalia catappa kernel oil extraction kinetics study.

Similarly, Agu et al. [65] used these five models to study the kinetics of oil extraction from Colocynthis vulgaris Schrad seed. They reported that with the exception of power law model, all the other models gave relatively good fit to the experimental extraction kinetic data. This can be clearly seen in Figure 1. Figure 1 shows the nonlinear kinetic plots of the experimental data, as well as the studied models, at varying particles sizes and at $55^{\circ} \mathrm{C}$, for the extraction of oil from Colocynthis vulgaris Schrad seed (source, Agu et al. [65]). In the work of Menkiti et al. [49], they found that hyperbolic, Elovich's and pseudo second order models 


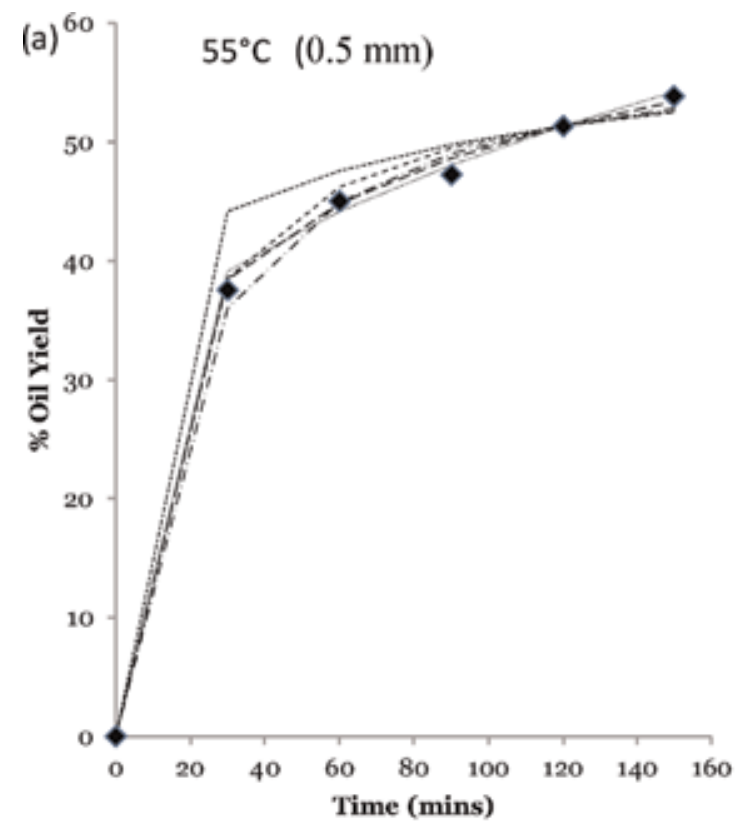

- Experimental Values

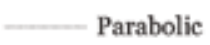

-..n-....- Power law

........ Hyperbolic

----- Elovich's

_...- Pseudo 2nd Order

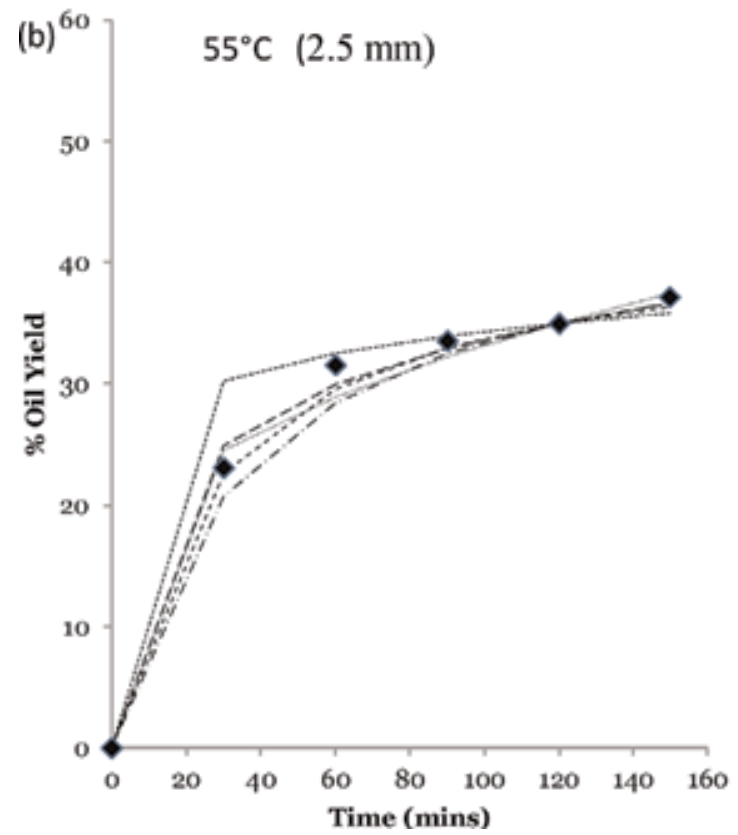

- Experimental Values

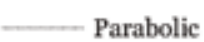

........... Power law

......... Hyperbolic

----- Elovich's

-..-- Pseudo 2nd Order

Figure 1.

Nonlinear kinetic plots at varying particle sizes $(0.5$ and $2.5 \mathrm{~mm})$ at $55^{\circ} \mathrm{C}$ for Colocynthis vugaris Shrad seeds oil extraction (source, Agu et al. [65]).

studied, gave good fit to the experimental kinetic data, with pseudo second order models as the best. However, in the work of Menkiti et al. [68], they found that in the nonlinear fitting of the extraction kinetics data into these five models, that it was only hyperbolic and pseudo second order models, that gave well fit to the extraction data. In their separate studies on safflower seed oil extraction, Han et al. [69] and Ayas and Yilmaz [70], used the Sovova's extended Lack's Model (SLM) alone, to model the extraction process and reported that the model gave good fit to the experimental data. 
Several researchers too numerous to mention have successfully used different extraction models to fit oil extraction kinetic data of a number of oil seeds/nuts. Over time, most researchers have modeled the extraction process they studied, using the pseudo second order model. This is because pseudo second order model has always fitted best to most solid-liquid extraction processes, as evident from some of the works earlier mentioned $[49,65,68]$. There is therefore need for researchers to direct their research interest, into the evaluation of the kinetics of Amaranth seed oil extraction, using these models.

Some of these known empirical kinetic models used to model solid-liquid extraction are briefly descried. The five two-parametric empirical kinetic models often used to model oil extraction from seeds/nuts are: parabolic diffusion, power law, hyperbolic, Elovich's and pseudo second-order models. Kinetic parameters of these models could be generated using both linear [49] and non-linear [65, 68] equations of the models. Prior to the empirical modeling of the extraction process, for Amaranth seed oil extractions, following assumptions are made on the basis of the empirical models:

- seed particles are isotropic and of equal size;

- distribution of extractive substances (oil) within the seed particles is uniform and varied only with time;

- neto diffusion occurs only towards the external surface of the seed particles;

- diffusion coefficient of extractive substances (oil) is constant.

However, for some models, there could be additional, specific assumptions that are introduced $[49,65,68]$. Table 2 shows the linear and nonlinear forms of the extraction kinetic models equations that could be used to fit Amaranth seed oil kinetic data. These models equations are briefly described sequentially.

\subsection{Parabolic diffusion model}

The generalized form of the parabolic diffusion model equation is shown in Eq. (1).

$$
\bar{q}=A_{0}+A_{1} t^{1 / 2}+A_{2} t
$$

\begin{tabular}{lll}
\hline Kinetic Models & Nonlinear Equs. & Linear Equs. \\
\hline Parabolic diffusion & $\bar{q}=A_{0}+A_{1} t^{1 / 2}$ & $\bar{q}=A_{0}+A_{1} t^{1 / 2}$ \\
Power law & $\bar{q}=B t^{1 / 2}$ & $\operatorname{In} \bar{q}=\operatorname{In} B+n L n t$ \\
Hyperbolic & $\bar{q}=\frac{c_{1} t}{1+C_{2} t}$ & $\frac{1}{\bar{q}}=\frac{1}{c_{1}} \times \frac{1}{t}+\frac{c_{2}}{c_{1}}$ \\
Elovich's & $\bar{q}=E_{0}+E_{1}$ Int & $\bar{q}=E_{0}+E_{1} \ln t$ \\
Pseudo 2 $2^{\text {nd }}$ order & $\bar{q}=\frac{C_{s}^{2} K t}{1+C_{5} K t}$ & $\frac{t}{c_{t}}=\frac{t}{K c_{s}^{2}}+\frac{t}{c_{s}}$ \\
\hline
\end{tabular}

Table 2.

Models names, nonlinear and linear forms of equations that can be used to model Amaranth seed oil extraction data. 
In the case of application of Eq. (1), for seed particles extraction, where chemical reaction is not involved, Eq. (1) can then be simplified to obtain Eq. (2) [71].

$$
\bar{q}=A_{0}+A_{1} t^{1 / 2}
$$

Eq. (2) is known as the parabolic diffusion equation. This model corresponds to the simple two-step extraction mechanism that consists of washing, followed by diffusion. The expression for $A_{0}$ is given in Eq. (3), while the constant $A_{1}$ is the diffusion rate constant. $A_{0}$ represents the extraction oil yield recovered instantaneously as the seed/nut material (Amaranth) is submersed into the solvent (i.e. at $\mathrm{t}=0$ ), and is called the washing coefficient [67].

$$
A_{0}=\frac{\bar{q}_{w}}{\bar{q}_{0}}
$$

Where $\bar{q}_{w}$ is the amount of extractive substance (oil) washed away instantaneously as the sample material (Amaranth seed) is submersed into the solvent, $\bar{q}_{0}$ is the amount of extractive substance in the sample material (Amaranth seed). Both $\bar{q}_{w}$ and $\bar{q}_{0}$ are expressed as g/100 g of the sample material. From Eq. (2), a plot of \% yield, $\bar{q}$ verses $\mathrm{t}^{1 / 2}$, gives $\mathrm{A}_{0}$ as the intercept, and $\mathrm{A}_{1}$ as the slope.

\subsection{Power law model}

This model equation was used to reveal the mechanisms that governed the diffusion of any active agent through non-swelling devices [67]. In terms of modeling oil extraction from seeds, Menkiti et al. [68] and Agu et al. [65], successfully fitted the obtained experimental kinetic data, from Terminalia catappa kernel and Colocynthis vulgaris Schrad seed extractions, respectively, into power law model equation. As such, this model can also be used successfully to model oil extraction from Amaranth seeds/grains. Eq. (4) is the generalized form of power law model equation.

$$
\bar{q}=B t^{n}
$$

Where, $\mathrm{B}$ is a constant incorporating the characteristics of the carrier-active system, and $\mathrm{n}$ is the diffusional exponent, indicative of transport mechanism. For extraction of materials (such as Amaranth seed), it is $\mathrm{n}<1$. The extraction yield predicted by this equation does not approach to unity (1) with time [67].

Hence, Eq. (4) can be re-written and n, replaced with $1 / 2$, since at any time, $n$ must be $<1$. Therefore, Eq. (4) can now be written as Eq. (5).

$$
\bar{q}=B t^{1 / 2}
$$

Eq. (5) is then linearized to obtain Eq. (6).

$$
\operatorname{In} \bar{q}=\operatorname{In} B+n L n t
$$

By plotting $\operatorname{In} \bar{q}$ against $\operatorname{Int}$, the intercept is obtained as $\operatorname{In} B$, while $\mathrm{n}$ is the slope.

\subsection{Hyperbolic model}

Hyperbolic model is a kinetic model that is often applied in food engineering science as pelegs model. This model has also been applied for oil extraction modeling from seeds/nuts. For instance, Menkiti et al. [49, 68], and Agu et al. [65], 
applied the nonlinear form of this model in oil extraction from Terminalia catappa kernel and Colocynthis vulgaris Schrad seed extractions, respectively. Eq. (7) is the general form of hyperbolic model $[67,72]$.

$$
\bar{q}=\frac{C_{1} t}{1+C_{2} t}
$$

The extraction is first-order at the beginning, and decreases to zero-order in the later phase of the process. When $\mathrm{C}_{2} \mathrm{t}<<1$, Eq. (7), then reduces to Eq. (8).

$$
\bar{q}=C_{1} t
$$

On linearizing Eqs. (7) and (9) is obtained.

$$
\frac{1}{\bar{q}}=\frac{1}{C_{1}} \times \frac{1}{t}+\frac{C_{2}}{C_{1}}
$$

The plot of $1 / \bar{q}$ that is $1 /$ yield against $1 / t$ in Eq. (9), gives intercept as $C_{2} / C_{1}$ and the slope as $1 / C_{1}$.

$C_{1}$ and $C_{2}$ are hyperbolic model parameters extraction rate at the beginning $\left(\min ^{-1}\right)$, and constant related to maximum extraction yield $\left(\min ^{-1}\right), \bar{q}$, respectively.

\subsection{Elovich's equation}

The general form of Elovich's equation written as a logarithmic relation is shown in Eq. (10) [71, 73]. Like in the other three models already discussed, Elovich's model has also been applied to oil extraction modeling. In the works of Agu et al. [65], and Menkiti et al. [49, 68], Elovich's model was applied using the nonlinear form of the model, for oil extraction modeling of Terminalia catappa kernel and Colocynthis vulgaris Schrad seed, respectively. Hence, Elovich's model can also be applied to the modeling of Amaranth seeds oil extraction.

$$
\bar{q}=E_{0}+E_{1} \operatorname{Int}
$$

The equation is derived under the assumption that the rate of extraction (in this case Amaranth oil extraction), decreases exponentially with increasing extraction yield, as could be seen in Eq. (11).

$$
\frac{d \bar{q}}{d t}=\beta \times \exp (-\alpha \bar{q})
$$

Where $\beta=E_{1} \times \exp \left(E_{0} / E_{1}\right)$ and $\alpha=1 / E_{1}$. When $\bar{q} \rightarrow 0$, then $d \bar{q} / d t \rightarrow \beta$, thus $\beta$ is the initial extraction rate. A plot of yield $\bar{q}$ verse $I n t$ in Eq. (10), gives $E_{0}$ as the intercept and $E_{1}$ as the slope. Where, $E_{0}$, and $E_{1}$ are Elovich equation parameters (L).

\subsection{Pseudo second order model}

In the case of the second-order rate law, the dissolution rate of the oil contained in the solid (in this case Amaranth seeds), into the solvent can be described by Eq. (12). Pseudo second order model equation has also been used to fit oil extraction data, obtained from oil seeds/nuts. This model was also used in its nonlinear form in the works of Agu et al. [65], and Menkiti et al. [49, 68], to fit the experimentally 
obtained kinetic data of Colocynthis vulgaris Schrad seed and Terminalia catappa kernel extractions, respectively. This model can also be used to the model of Amaranth seeds oil extraction.

$$
\frac{d C_{t}}{d t}=K\left(C_{s}-C_{t}\right)^{2}
$$

where $\mathrm{K}$ is the second-order extraction rate constant $\left(\mathrm{L} \mathrm{g} \mathrm{g}^{-1} \mathrm{~min}^{-1}\right) ; C_{s}$ is the extraction capacity (concentration of oil at saturation in $\mathrm{g} \mathrm{L}^{-1}$ ); $C_{t}$ is the concentration of oil in the solution at any time $\left(\mathrm{g} \mathrm{L}^{-1}\right), \mathrm{t}(\mathrm{min})$.

The initial extraction rate defined as $\mathrm{h}$, when $\mathrm{t}$ and $C_{t}$ approach 0 , can be expressed as shown in Eq. (13).

$$
h=K C_{s}^{2}
$$

Considering the boundary conditions at $t=0$ to $t$ and $C_{t}=0$ to $C_{t}$, the integrated rate law for pseudo second-order extraction was obtained as Eq. (14).

$$
\bar{q}=\frac{C_{s}^{2} K t}{1+C_{s} K t}
$$

The linearized form of Eq. (14), gives rise to Eq. (15).

$$
\frac{t}{C_{t}}=\frac{t}{K C_{s}^{2}}+\frac{t}{C_{s}}
$$

The initial extraction rate, $\mathrm{h}$, the extraction capacity, $\mathrm{C}_{\mathrm{s}}$ and the pseudo second order extraction rate constant, $\mathrm{k}$, can be calculated experimentally by plotting $t / C_{t}$ versus $\mathrm{t}$ in Eq. (15) [74].

\section{Thermodynamic studies of oil extraction from Amaranth seeds}

It is very important to consider the thermodynamic of any oil extraction process. In the case of the thermodynamics of Amaranth seed oil extraction, there could be little or no information available. There is therefore need for researcher to carry out this research. Thermodynamic parameters like enthalpy $(\Delta \mathrm{H})$, entropy $(\Delta \mathrm{S})$ and Gibbs free energy $(\Delta G)$ can be estimated using known thermodynamic equation [49].

The thermodynamic parameters $(\Delta \mathrm{H}, \Delta \mathrm{S}$ and $\Delta \mathrm{G})$ for the extraction of oil from a particular seed, such as Amaranth seed, using n-hexane as solvent, can be estimated using Eqs. (16) and (17). However, Eq. (18) is used occasionally to calculate the equilibrium constant $\mathrm{K}$.

$$
\begin{gathered}
\Delta G=-R T \operatorname{In} K \\
\text { In } K=-\frac{\Delta G}{R T}=-\frac{\Delta H}{R T}+\frac{\Delta S}{R} \\
K=\frac{Y_{T}}{Y_{u}}=\frac{m_{L}}{m_{s}}
\end{gathered}
$$

Where $\mathrm{K}$ is equilibrium constant, $Y_{T}$ is the yield of oil at temperature T, $Y_{u}$ is the percentage of the unextracted oil. Similarly, $m_{L}$ is amount of a particular seed oil (in this case Amaranth oil) in liquid at equilibrium temperature T, while $m_{s}$ is amount 
of a particular seed oil (Amaranth oil) in solid at equilibrium temperature $\mathrm{T}$. $\mathrm{R}$ is gas constant $(8.314 \mathrm{~J} / \mathrm{mol} \mathrm{K})$, while $\Delta \mathrm{H}, \Delta \mathrm{S}$ and $\Delta \mathrm{G}$ are the enthalpy, entropy and Gibbs free energy of extraction $(\mathrm{KJ} / \mathrm{mol} \mathrm{K})$, respectively [75].

Eq. (17) is a Van't Hoff relation, and plotting of $I n K$ against $1 / T$, is used to determine the values of $\Delta \mathrm{H}, \Delta \mathrm{S}$ and $\Delta \mathrm{G}$. The plot gives $\Delta \mathrm{H} / \mathrm{R}$ as the slope and $\Delta \mathrm{S} / \mathrm{R}$ as the intercept. The values of $\mathrm{K}, \Delta \mathrm{H}, \Delta \mathrm{S}$ and $\Delta \mathrm{G}$ for the extraction of a particular seed oil (e.g. Amaranth oil) using n-hexane can be calculated using Eqs. (16)-(18).

It is important to know that the values of $\Delta \mathrm{G}, \Delta \mathrm{S}$ and $\Delta \mathrm{H}$ for the extraction of oil from seeds/nuts, using solvent extraction method, differ for different seeds/nuts. As such, the thermodynamic of oil extraction from Amaranth seeds needs to be evaluated by researchers, as limited or no research article in that regards is available. Due to the differences in the thermodynamic parameters of different seeds/ nuts, several researchers have reported the thermodynamics of oil extraction for good number seeds/nuts.

For instance, the values of $\Delta \mathrm{G}, \Delta \mathrm{S}$ and $\Delta \mathrm{H}$, respectively, were $10.94-13.35 \mathrm{~kJ} / \mathrm{mol}, 33.10-39.57 \mathrm{~J} / \mathrm{mol} \mathrm{K}$ and $0.12-1.25 \mathrm{~kJ} / \mathrm{mol}$, for solid coconut waste oil extraction [76]. Amin et al. [77], reported that for Jatropha curcas, the $\Delta \mathrm{G}$, $\Delta \mathrm{S}$ and $\Delta \mathrm{H}$ values were, $-4.928 \mathrm{~kJ} / \mathrm{mol}, 15.275 \mathrm{~J} / \mathrm{mol} \mathrm{K}$ and $0.1586 \mathrm{~kJ} / \mathrm{mol}$, respectively. For fluted pumpkin extraction, the $\Delta \mathrm{G}, \Delta \mathrm{S}$ and $\Delta \mathrm{H}$ values were -3.902 to $-8.909 \mathrm{~kJ} / \mathrm{mol} \mathrm{K}, 0.234 \mathrm{~kJ} / \mathrm{mol} \mathrm{K}$ and $78.84 \mathrm{~kJ} / \mathrm{mol}$, respectively [78]. In the work of Agu et al. [65], the values of $\Delta \mathrm{G}, \Delta \mathrm{S}$ and $\Delta \mathrm{H}$, respectively, were $-64.82 \mathrm{~kJ} / \mathrm{mol}$, $1.22 \mathrm{~J} / \mathrm{mol} \mathrm{K}$ and $333.40 \mathrm{~kJ} / \mathrm{mol}$, for Colocynthis vulgaris Schrad seed oil extraction. Furthermore, for sunflower oil extraction process, Topallar and Geçgel [79], reported that the $\Delta \mathrm{G}, \Delta \mathrm{S}$ and $\Delta \mathrm{H}$ values were $-1.07 \mathrm{~kJ} / \mathrm{mol}, 36.75 \mathrm{~J} / \mathrm{mol} \mathrm{K}$ and $11.2 \mathrm{~kJ} / \mathrm{mol}$, respectively.

As earlier highlighted, the thermodynamic parameters for the extraction of oil from Amaranth seeds/grains could be evaluated by the plotting of In $K$ against $1 / T$. Since there is no literature information on thermodynamics of Amaranth seeds oil extraction, figure from similar published work was used as an illustration. For instance, Figure 2, shows the plots of In $K$ (equilibrium constant) verses $1 / T$, at different particle sizes, for Colocynthis vulgaris Schrad seed [65]. Finally, from the values of $\Delta \mathrm{G}, \Delta \mathrm{S}$ and $\Delta \mathrm{H}$, obtained by the aforementioned authors, they indicated the spontaneity, irreversibility and endothermic nature of the extraction processes.

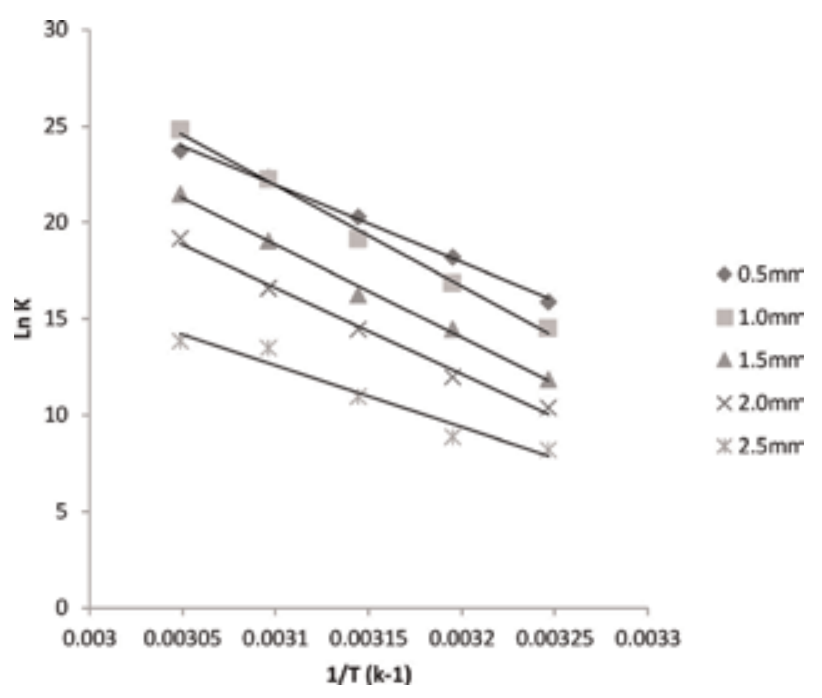

Figure 2.

Plot of In $K$ (equilibrium constant) versus $1 / T$ (temperature, $K^{-1}$ ) for the five different particle sizes (source, Agu et al. $[65])$. 


\section{Conclusion}

It could be concluded from this chapter that due to the industrial, economic and health/nutritional benefits of Amaranth seeds oil, the insight into research on the kinetics and thermodynamics of Amaranth seed oil extraction has be made. It has also been justified that Soxhlet apparatus, using solvent like hexane, is an excellent conventional method for Amaranth seed/grains oil extraction. This chapter has highlighted the importance of oil extraction kinetics, as well as fitting experimentally obtained kinetic data, into known empirical kinetic models. Also, the need for thermodynamics studies of oil extraction processes, especially with respect to Amaranth seed oil extraction process, has been emphasized. Finally, there is need for researchers to now direct their studies towards the kinetics and thermodynamics of Amaranth seed oil extraction process, since there is little, or no literature information in this regards.

\section{Author details}

Chinedu M. Agu ${ }^{1 *}$ and Albert C. Agulanna ${ }^{2}$

1 Department of Chemical Engineering, Nnamdi Azikiwe University, Awka, Nigeria

2 Materials and Energy Technology Department, Projects Development Institute (PRODA), Enugu, Nigeria

*Address all correspondence to: eduetal@yahoo.com

\section{IntechOpen}

(C) 2020 The Author(s). Licensee IntechOpen. This chapter is distributed under the terms of the Creative Commons Attribution License (http://creativecommons.org/licenses/ by/3.0), which permits unrestricted use, distribution, and reproduction in any medium, provided the original work is properly cited. (c) BY 


\section{References}

[1] Gamel TH, Mesallam AS, Damir AA, Shekib LA, Linssen JP. Characterization of Amaranth seed oil. Journal of Food Lipids. 2007;14:323-334

[2] Krulj J, Brlek T, Pezo L, Brkljaca J, Popovic S, Zekovic Z, et al. Extraction methods of Amaranthus sp. grain oil isolation. Journal of the Science of Food and Agriculture. 2016;96:3552-3558

[3] Dhellot JR, Matouba E, Maloumbi MG, Nzikou JM, Ngoma Safou DG, Linder M, et al. Extraction, chemical composition and nutritional characterization of vegetable oils: Case of Amaranthus hybridus (var 1 and 2) of Congo Brazzaville. African Journal of Biotechnology. 2006;5(11):1095-1101

[4] Lyon CK, Becker R. Extraction and refining of oil from Amaranth seed. Journal of the American Oil Chemists' Society. 1987;64:233-236

[5] Sun H, Wiesenborn D, Rayas-Duarte P, Mohamed A, Hagen K. Bench-scale processing of Amaranth seed for oil. Journal of the American Oil Chemists' Society. 1995;72:1551-1555

[6] He H-P, Corke H. Oil and squalene in Amaranthus grain and leaf. Journal of Agricultural and Food Chemistry. 2003; 51:7913-7920

[7] Becker R. Preparation, composition, and nutritional implication of Amaranth seed oil. Cereal Foods World. 1989; 34(11):950-953

[8] Bruni R, Medici A, Guerrini A, Scalia S, Poli F, Muzzoli M, et al. Amaranthus caudatus seed oil, a nutraceutical resources from Ecuadorian flora. Journal of Agriculture, Food and Chemistry. 2001;49:5455-5460

[9] Becker R. Amaranth oil: Composition, processing, and nutritional qualities. In: Paredes-Lopez
O, editor. Amaranth Biology, Chemistry and Technology. Boca Raton: CRC Press; 1994. pp. 133-144

[10] He H-P, Corke H, Cai J-G. Supercritical carbon dioxide extraction of oil and squalene from Amaranthus grain. Journal of Agricultural and Food Chemistry. 2003;51:7921-7925

[11] Westerman D, Santos RCD, Bosley JA, Rogers JS, Al-Duri B. Extraction of Amaranth seed oil by supercritical carbon dioxide. Journal of Supercritical Fluids. 2006;37:38-52

[12] Leon-Camacho M, Garcia-Gonzalez DL, Aparicio R. A detailed and comprehensive study of Amaranth (Amaranthus cruentus) oil fatty profile. European Food Research and Technology. 2001;213:349-355

[13] Belitz HD, Grosch W. Food Chemistry. 2nd ed. Berlin, Heidelberg, Germany: Springer-Verlag; 1999. pp. 631-692

[14] Ortega JAA, Zavala AM, Hernandez MC, Reyes JD. Analysis of trans fatty acids production and squalene variation during amaranth oil extraction. Central European Journal of Chemistry. 2012;10 (6):1773-1778

[15] Rosales-Garcia T, Jimenez-Martinez C, Cardador-Martinez A, Martin-del Campo ST, Galicia-Luna LA, TellezMedina DI, et al. Squalene Extraction by supercritical fluids from traditional puffed Amaranthus hypochondriacus seeds. Journal of Food Quality. 2017:1-9. DOI: $10.1155 / 2017 / 6879712$

[16] Aguilera Y, Dorado ME, Prada FA, Martınez JJ, Quesada A, Ruiz-Gutierrez $\mathrm{V}$. The protective role of squalene in alcohol damage in the chick embryo retina. Experimental Eye Research. 2005;80(4):535-543 
[17] Kohno Y, Egawa Y, Itoh S, Nagaoka S-I, Takahashi M, Mukai K. Kinetic study of quenching reaction of singlet oxygen and scavenging reaction of free radical by squalene in nbutanol. Biochimica et Biophysica Acta (BBA) Lipids and Lipid Metabolism. 1995; 1256(1):52-56

[18] Warleta F, Campos M, Allouche Y, et al. Squalene protects against oxidative DNA damage in MCF10A human mammary epithelial cells but not in MCF7 and MDA-MB-231 human breast cancer cells. Food and Chemical Toxicology. 2010;48(4): 1092-1100

[19] Rao CV, Newmark HL, Reddy BS. Chemopreventive effect of squalene on colon cancer. Carcinogenesis. 1998; 19(2):287-290

[20] Hernandez Y, Lobo MG, Gonzalez $M$. Factors affecting sample extraction in the liquid chromatographic determination of organic acids in papaya and pineapple. Food Chemistry. 2009;114(2):734-741

[21] Majors RE. An overview of sample preparation methods for solid. LC-GC Europe. 1999;17(6):8-13

[22] Azmir J, Zaidul ISM, Rahman MM, Sharif KM, Mohamed A, Sahena F, et al. Techniques forextraction of bioactive compounds from plant materials: A review. Journal of Food Engineering. 2013;117:426-436

[23] Reyes-Jurado F, Franco-Vega A, Ramirez-Corona N, Palou E, LopezMalo A. Essential oils: Antimicrobial activites, extraction methods, and their modeling. Food Engineering Reviews. 2014. DOI: $10.1007 /$ s12393-014-9099-2

\section{[24] Wang L, Weller CL. Recent} advances in extraction of nutra-ceuticals from plant. Trends in Food Science and Technology. 2006;17:300-312
[25] Edgar U, Marcia J, Jaime O. Effect of pretreatment with microwaves on mechanical extraction yield and quality of vegetable oil from Chilean hazelnuts (Gevuina avellana Mol). Innovative Food Science and Emerging Technologies. 2008;9(4):495-500

[26] Reverchon E, Marco ID. Review: Supercritical fluid extraction and fractionation of natural matter. Journal of Supercritical Fluids. 2006;38(2):146-166

[27] Verma A, Hartonen K, Riekkola ML. Optimization of supercritical fluid extraction of indole alkaloids from Catharanthus roseus using experimental design methodology-Comparison with other extraction techniques.

Phytochemical Analysis. 2008;19(1):

52-63

[28] Zhao S, Zhang D. An experimental investigation into the solubility of Moringa oleifera oil in supercritical carbon dioxide. Journal of Food Engineering. 2014;138:1-10

[29] Mezzomo N, Martinez J, Ferreira SRS. Supercritical fluid extraction of peach (Prunus persica) almond oil: Kinetics, mathematical modeling and scale-up. Journal of Supercritical Fluids. 2009;51:10-16

[30] Erdogam S, Ates B, Durmaz G, Yilmaz I, Seckin T. Pressurized liquid extraction of phenolic compounds from Anatolia propolis and their radical scavenging capacities. Food and Chemical Toxicology. 2011;49(7):1592-1597

[31] Nieto A, Borrulli F, Pocurull E, Marce RM. Pressurized liquid extraction: A useful technique to extract pharmaceuticals and personal-care products from sewage sludge. TrAC Trends in Analytical Chemistry. 2010; 29(7):752-764

[32] Alupului A. Microwave extraction of active principles from medicinal plants. UPB Scientific Bulletin, Series B: 
Chemistry and Materials Science. 2012;74(2):129-142

[33] Asghari J, Ondruschka B, Mazaheritehrani M. Extraction of bioactive chemical compounds from the medicinal Asian plants by microwave irradiation. Journal of Medical Plants Research. 2011;5(4):495-506

[34] Chiremba C, Rooney LW, Trust BJ. Microwave-assisted extraction of bound phenolic acids in bran and flour fractions from sorghum and maize cultivars varying in hardness. Journal of Chromatography A. 2012;1012(2): 119-128

[35] Goula AM. Ultrasound-assisted extraction of pomegranate seed oilKinetic modeling. Journal of Food Engineering. 2013;117:492-498

[36] Yolmeh M, Najafi MBH, Farhoosh R. Optimization of ultrasound-assisted extraction of natural pigment from annatto seeds by response surface methodology (RSM). Food Chemistry. 2014;155:319-324

[37] Zu G, Zhang R, Yang L, Ma C, Zu Y, Wang W, et al. Ultrasound-assisted extraction of carnosic acid and rosmarinic acid using ionic liquid solution from Rosmarinus officinalis. International Journal of Molecular Sciences. 2012;13(9):11027-11043

[38] Lopez N, Puertolas E, Condon S, Alvarez I, Raso J. Effects of pulsed electric fields on the extraction of phenolic compounds during the fermentation of must of Tempranillo grapes. Innovative Food Science and Emerging Technologies. 2008;9(4):477-482

[39] Delsart C, Ghidossi R, Poupot C, Grimi N, Vorobiev E, Milisic V, et al. Enhanced extraction of phenolic compounds from merlot grapes by pulsed electric field treatment. American Journal of Enology and Viticulture. 2012;63(2):205-211
[40] Puri M, Sharma D, Barrow CJ. Enzyme-assisted extraction of bioactives from plants. Trends in Biotechnology. 2012;30(1):37-44

[41] Gomez-Garcia R, Martinez-Avila GCG, Aguilar CN. Enzyme-assisted extraction of antioxidative phenolics from grape (Vitis vinifera L) residues. 3 Biotech. 2012;2:297-300. DOI: 10.1007/s13205-012-0055-7

[42] Adebayo SE, Orhevba BA, Adeoye PA, Musa JJ, Fase OJ. Solvent extraction and characterization of oil from African star apple (Chrysophyllum albidum) seeds. Academic Research International. 2012;3(2):178-183

[43] Chan KW, Ismail M. Supercritical carbon dioxide fluid extraction of Hibiscus cannabinus L. seed oil: A potential solvent-free and high antioxidative edible oil. Food Chemistry. 2009;114:970-975

[44] Mariod AA, Ismail M, Mattha B. Comparison of supercritical fluid and hexane extraction methods in extracting Kenaf (Hibiscus cannabinus) seed oil lipids. Journal of the American Oil Chemists' Society. 2011;88:931-935

[45] Niu L, Li J, Chen M-S, Xu Z-F. Determination of oil contents in Sacha inchi (Plukenetia volubilis) seeds at different developmental stages by two methods: Soxhlet extraction and timedomain nuclear magnetic resonance. Industrial Crops and Products. 2014;56: 187-190

[46] Omeh YS, Ezeja MI, Ugwudike PO. The physiochemical properties and fatty acid profile of oil extracted from Irvingia gabonensis seeds. International Journal of Biochemistry and Biotechnology. 2012; 2(2):273-275

[47] Lasekan O, Abdulkarim SM.

Extraction of oil from tiger nut (Cyperus esculentus L.) with supercritical carbon 
dioxide (SC-CO ${ }_{2}$ ). LWT-Food Science and Technology. 2012;47:287-292

[48] Dos Santos ICF, De Carvalho SHV, Solleti JI, Ferreira dela Sellas W, Teixeira da Silva de La Sallesc K, Meneghetti SMP. Studies of Terminalia catappa L. oil: Characterization and biodiesel production. Bioresource Technology. 2008;99:6545-6549

[49] Menkiti MC, Agu CM, Udeigwe TK. Extraction of oil from Terminalia catappa L.: Process parameter impacts, kinetics, and thermodynamics. Industrial Crops and Products. 2015;77: 713-723

[50] Adepoju TF, Okewale AO, Olalekan AP, Adesina OA. Optimization, physicochemical analysis, proximate composition, elemental contents and fatty acid profile of oil extracted from Terminalia catappa L. International Journal of Advanced Research. 2014; 2(1):1-10

[51] Luque de Castro MD, Gracia-Ayuso LE. Soxhlet extraction of solid materials: An outdated technique with a promising innovative future. Analytica Chimica Acta. 1998;369:1-10

[52] Li H, Pordesimo L, Weiss J. High intensity ultrasound-assisted extraction of oil soybeans. Food Research International. 2004;37:731-738

[53] Rout PK, Naik SN, Rao YR, Jadeja G, Maheshwari RC. Extraction and composition of volatiles from Zanthoxylum rhesta: Comparison of supercritical $\mathrm{CO}_{2}$ and traditional processes. The Journal of Supercritical Fluids. 2007;42:334-341

[54] Cuevas MS, Rodrigues CEC, Meirelles AJA. Effect of solvent hydration and temperature in the deacidification process of sunflower oil using ethanol. Journal of Food Engineering. 2009;95:291-297
[55] Aquino LP, Borges SV, Queiroz F, Antoniassi R, Cirillo MA. Extraction of oil from pequi fruit (Caryocar brasiliense, Camb.) using several solvents and their mixtures. Grasas y Aceites. 2011;62(3):245-252

[56] Rodríguez-Rojo S, Visentin A, Maestri D, Cocero MJ. Assisted extraction of resemery antioxidants with green solvents. Journal of Food Engineering. 2012;109:98-103

[57] De Oliveira RC, de Barros STD, Gimenes ML. The extraction of passion fruit oil with green solvents. Journal of Food Engineering. 2013;117:458-463

[58] Fernández MB, Perez EE, Crapiste GH, Nolasco SM. Kinetic study of canola oil and tocopherol extraction: Parameter comparison of nonlinear models. Journal of Food Engineering. 2012;111:682-689

[59] Matthäus B, Brühl L. Comparison of different methods for the determination of the oil content in oilseeds. Journal of the American Oil Chemists Society. 2001;78:95-102

[60] Patricelli A, Assogna A, Casalaina A, Emmi E, Sodini G. Fattori che influenzano l'estrazione dei lipidi da semi decorticati di girasole. Rivista Italiana Delle Sostanze Grasse. 1979;56: 136-142

[61] So GC, Macdonald DG. Kinetics of oil extraction from canola (rapeseed). Canadian Journal of Chemical Engineering. 1986;64:80-86

[62] Sasmaz DA. Evaluation of diffusion coefficient of rapeseed oil during solvent extraction with hexane. Journal of the American Oil Chemists' Society. 1996;73(5):669-671

[63] Perez EE, Carelli AA, Crapiste GH. Temperature-dependent diffusion coefficient of oil from different sunflower seeds during extraction with 
hexane. Journal of Food Engineering. 2011;105:180-185

[64] Baümler ER, Crapiste GH, Carelli AA. Solvent extraction: Kinetic study of mayor and minor compounds. Journal of the American Oil Chemists' Society. 2010;87:1489-1495

[65] Agu CM, Kadurumba CH, Agulanna AC, Aneke OO, Agu IJ, Nonlinear Kinetics EJN. Thermodynamics, and parametric studies of Colocynthis vugaris Shrad seeds oil extraction. Industrial Crops and Products. 2018;123:386-400

[66] Meziane S, Kadi H, Daoud K, Hannane F. Application of experimental design method to the oil extraction from olive cake. Journal of Food Processing and Preservation. 2009;33:176-185

[67] Kitanović S, Milenovic D, Veeljkovic VB. Empirical kinetic models for the resinoid extraction from aerial parts of St John's Wort (Hypericum Perforatum L.). Journal of Biochemical Engineering. 2008;41:1-11

[68] Menkiti MC, Agu CM, Udeigwe TK. Kinetic and parametric studies for the extractive synthesis of oil from Terminalia catappa L. kernel. Reaction Kinetics, Mechanisms and Catalysis. 2017;120:129-147

[69] Han X, Cheng L, Zhang R, Bi J. Extraction of safflower seed oil by supercritical $\mathrm{CO}_{2}$. Journal of Food Engineering. 2009;92:370-376

[70] Ayas N, Yilmaz O. A shrinking core model and empirical kinetic approaches in supercritical $\mathrm{CO}_{2}$ extraction of safflower seed oil. Journal of Supercritical Fluids. 2014;94:81-90

[71] Chauhan G, Pant KK, Nigam KDP. Conceptual mechanism and kinetic studies of chelating agent assisted metal extraction process from spent catalyst. Journal of Industrial and Engineering
Chemistry. 2015. DOI: 10.1016/j. jiec.2015.01.017.

[72] Rakotondramasy RL, Haret JL, Porte C, Faudet H. Solid-liquid extraction of protopiine from Fumaria officinalis. Lanalysis determination, kinetic reaction and model building. Separation and Purification Technology. 2007;54:

253-261

[73] Paterson IF, Chowdhry BZ, Leharne SA. Polycyclic aromatic hydrocarbon extraction from a coal tar-contaminated soil using aqueous solution of nonionic surfactants. Chemosphere. 1999;38(13): 3095-3107

[74] Muhammad HH, Hasfalina CM, Hishamuddin J, Zurina ZA.

Optimization and kinetics of essential oil extraction from citronella grass by ohmic heated hydro distillation.

International Journal of Chemical Engineering and Application. 2012;3(3): 173-176

[75] Liauw MY, Natan FA, Widiyanti P, Ikasari D, Indraswati N, Soetaredjo FE. Extraction of neem oil (Azadirachta indica A.) using $\mathrm{n}$-hexane and ethanol. Study of oil quality, kinetics and thermodynamics. ARPN Journal of Engineering and Applied Sciences. 2008;3(3):1-6

[76] Sulaiman S, Abdul Aziz AR, Arova MK. Optimization and modeling ofextraction of solid coconut waste oil. Journal of Food Engineering. 2013;114: 228-234

[77] Amin S, Hawash G, El Diwani S, Rafe E. Kinetics and thermodynamics of oil extraction from Jatropha curcas in aqueous acidic hexane solutions. Journal of American Science. 2010;6(11):

293-300

[78] Nwabanne JT. Kinetics and thermodynamics study of oil extraction from fluted pumpkin seed. International 
Journal of Multidisciplinary Science and Engineering. 2012;3(6):11-15

[79] Topallar H, Geçgel U. Kinetics and thermodynamics of oil extraction from sunflower seeds in the presence of aqueous acidic hexane solutions. Turkish Journal of Chemistry. 2000;24: 247-253 



\section{Edited by Viduranga Y. Waisundara}

Pseudocereals, belonging to the genus Amaranthus, have been cultivated for their grains for 8,000 years or more. The grain was a staple food of the Aztecs and was also considered an integral part of Aztec religious ceremonies. The book primarily focuses on the nutrient properties of amaranth and expresses its viewpoint in considering this crop as a remedy for many nutrient deficiencies and curbing food insecurity. The functional properties of the grain are immense and it is clear that the crop would be a valuable agricultural product around the world.

\section{IntechOpen}

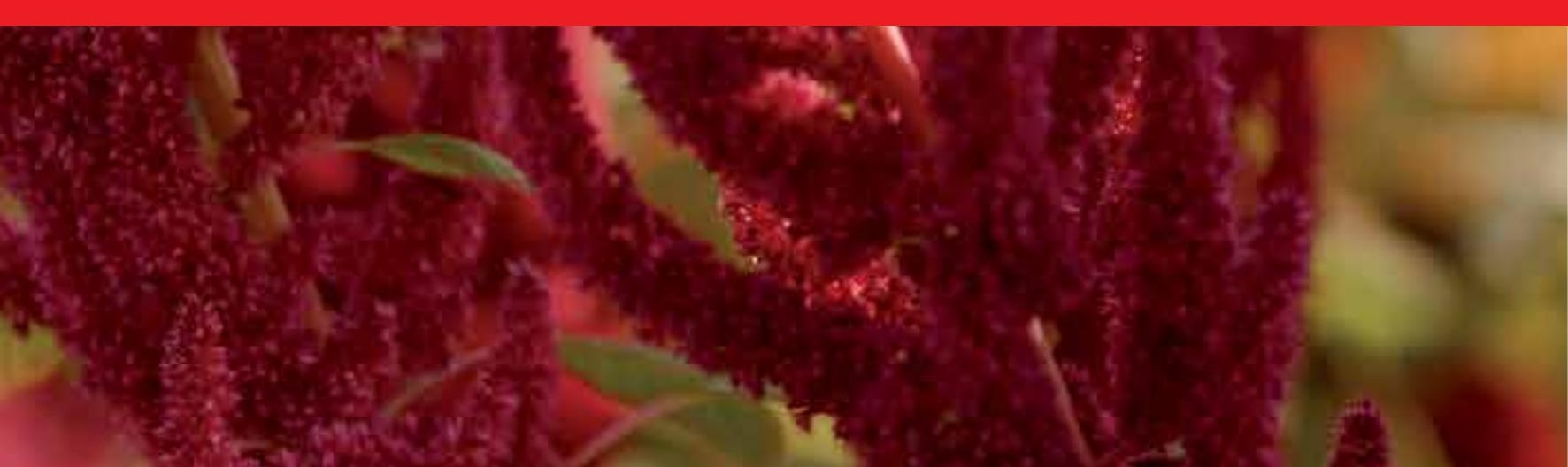

